Szegedi Tudományegyetem

Földtudományok Doktori Iskola

\title{
A TURISZTIKAI KLÍMAPOTENCIÁL ÉRTÉKELÉSE EREDETI, VALAMINT TOVÁBBFEJLESZTETT ÉS A MAGYAR LAKOSSÁGHOZ ADAPTÁLT ESZKÖZÖKKEL
}

\author{
Doktori $(\mathrm{PhD})$ értekezés
}

\section{Kovács Attila}

Témavezetők:

\author{
Dr. Unger János \\ tanszékvezető egyetemi tanár \\ Dr. Kántor Noémi \\ tudományos munkatárs
}

SZTE Természettudományi és Informatikai Kar Éghajlattani és Tájföldrajzi Tanszék 


\section{Tartalomjegyzék}

1. Bevezetés.

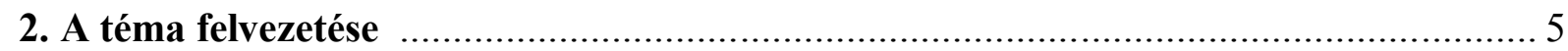

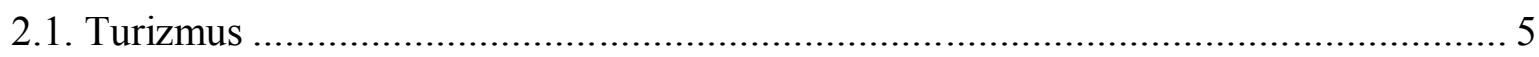

2.1.1. A turizmus fogalma, jellemzői, föbb formái .................................................. 5

2.1.2. A turizmus által hasznositható eröforrások ........................................................ 7

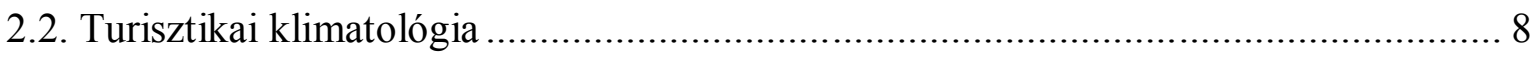

2.2.1. Az éghajlat mint a turizmus egyik kulcsfontosságú eröforrása .......................... 8

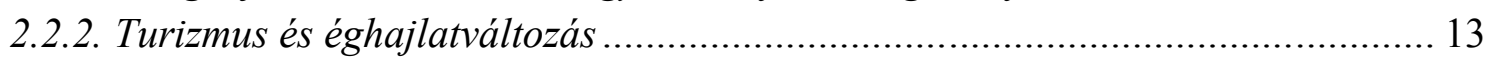

2.2.3. Időjárási és éghajlati információk, szerepük a turizmusban ............................. 16

2.2.4. Az éghajlati információk turisztikai értékelésének alapelvei ............................. 18

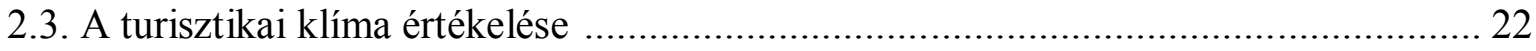

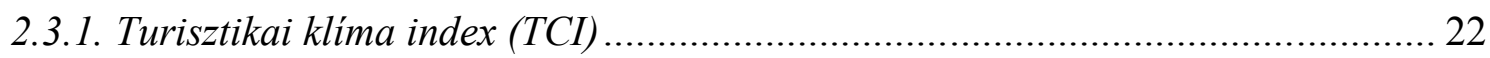

2.3.2. Második generációs turisztikai klíma index (CIT) ........................................ 28

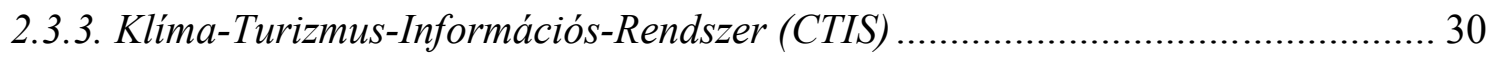

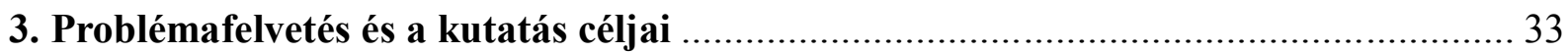

3.1. A turisztikai klíma értékelése során felmerülő hiányosságok ................................ 33

3.2. A termikus viszonyok szubjektív értékelésében jelentkező különbségek ................. 36

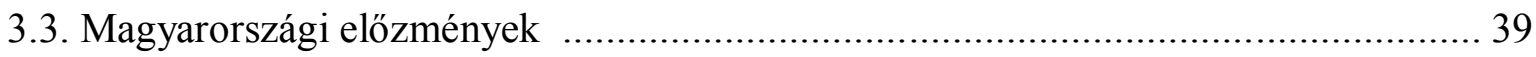

3.3.1. Turisztikai desztinációk klímapotenciáljának értékelése .................................. 39

3.3.2. Az éghajlatváltozás turizmusra gyakorolt hatásának vizsgálata ....................... 40

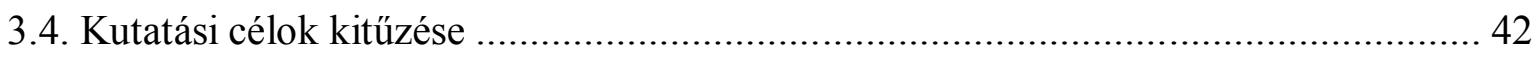

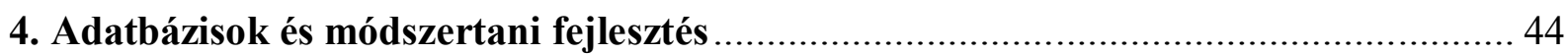

4.1. A turisztikai klíma értékelésének adaptálása a magyar lakossághoz ........................ 44

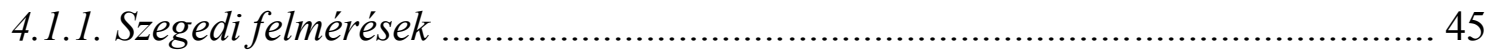

4.1.2. A turisztikai klímát értékelö eszközök módositási koncepciói ........................... 53

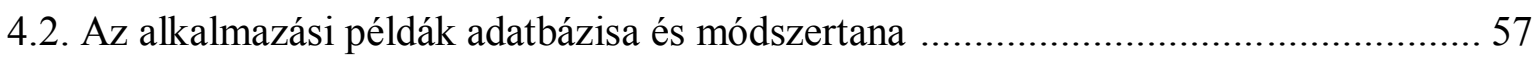

4.2.1. A turisztikai desztinációk értékelésének adatbázisa és módszertana .................. 57

4.2.2. A turisztikai klímapotenciál-változás vizsgálatához használt adatbázis és

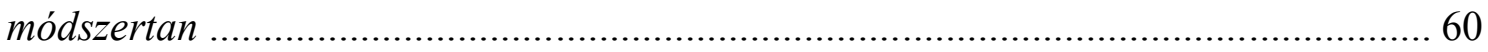

5. Módszertani fejlesztéshez kapcsolódó eredmények .......................................... 64

5.1. Az interjúalanyok jellemzői és a humán-biometeorológiai háttérkörülmények ......... 64

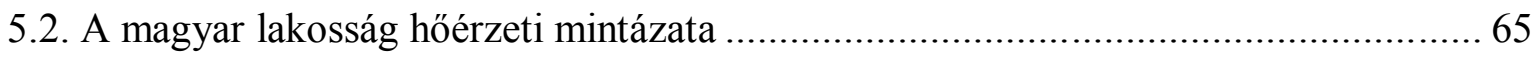

5.3. A hazai lakossághoz adaptált turisztikai klímát értékelő eszközök ........................... 68

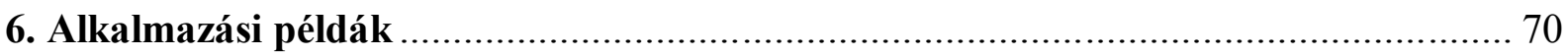

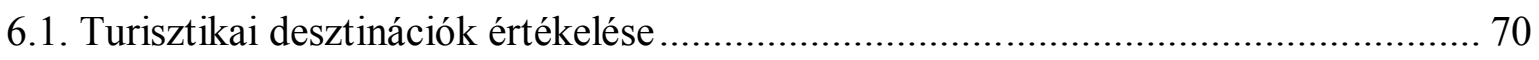

6.1.1. Turisztikai klíma index és módositott Turisztikai klíma index .......................... 70

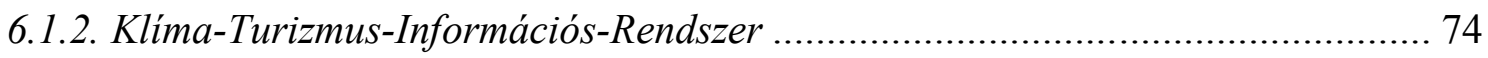

6.2. A turisztikai klímapotenciál mintázatának változása ........................................... 81 


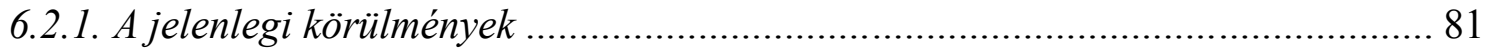

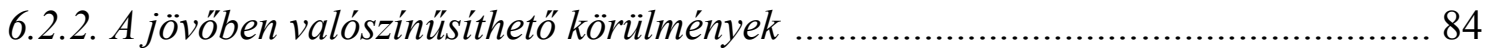

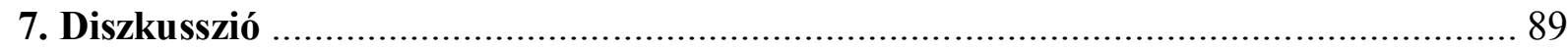

7.1. Az alkalmazott eszközök értékelése a szakirodalom és saját tapasztalatok tükrében

7.2. A módszertani fejlesztés és az adaptálás értékelése, valamint nemzetközi

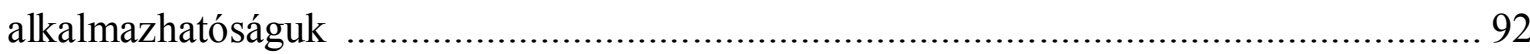

7.3. Az alkalmazási példák értékelése a szakirodalom és a gyakorlati szféra tükrében

8. Összefoglalás 97

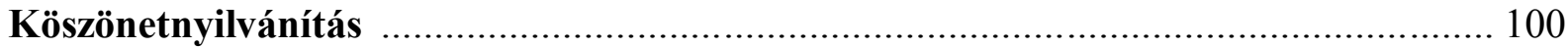

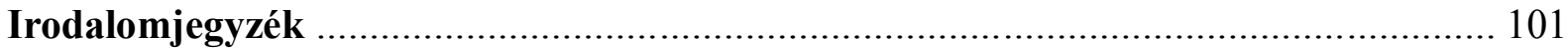

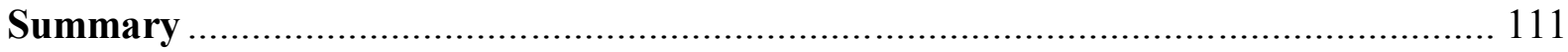

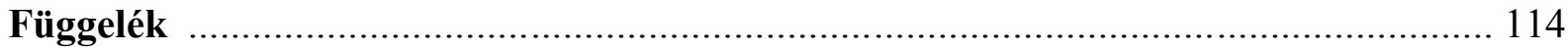




\section{Bevezetés}

Egy terület turisztikai vonzerejét számos tényezö befolyásolja, melyek közül az éghajlat az egyik legjelentősebb összetevő. A légköri klímaelemek komplex kölcsönhatásai lehetővé tehetik vagy korlátozhatják bizonyos turisztikai tevékenységek folytatását, illetve erősíthetik vagy ronthatják egy terület megítélését valamely tevékenység szempontjából. A fenntartható turizmusfejlesztés egyik kulcstényezője, hogy tisztában legyünk azzal, mennyire megfelelőek a különböző turisztikai tevékenységek éghajlati feltételei egy adott régióban. A turisztikai klímapotenciál ismeretében a szolgáltatók a kínálati elemeket optimálisabban tudják kialakítani és elosztani. A turisták számára pedig az éghajlati körülmények ismerete fontos szempont lehet a célterületek, a kedvező időszakok és a tevékenységformák kiválasztásában. A klimatikus viszonyok változékonysága hatással van a látogatók komfortérzetére és a célterülettel kapcsolatos elégedettségére, ami által a turisztikai keresletet is erőteljesen befolyásolhatja.

A turizmus amellett, hogy napjaink egyik dinamikusan fejlődő gazdasági ágazata, kitüntetett abból a szempontból is, hogy rendkívül érzékenyen reagál az éghajlat megváltozására. A klimatikus körülmények változása különböző mértékben befolyásolja az egyes turisztikai célterületeket, illetve tevékenységeket, s indirekt módon számos egyéb környezeti erőforrásra is hatást gyakorol. Napjaink egyik jelentős kihívása, hogy megteremtsük a turizmusipar számára a klímaváltozás elkerülhetetlen hatásaihoz való alkalmazkodás feltételeit. A célirányos adaptációs stratégiák fejlesztését és gyakorlatba való átültetését elösegíthetjük a klímapotenciálban bekövetkezett $\mathrm{s}$ a jövőben várható változások elemzése révén.

Doktori disszertációm a turisztikai klimatológia területére esik, amely a turizmus és az éghajlati viszonyok kapcsolatrendszerét vizsgálja. Az utóbbi évtizedek során több értékelő eljárást (eszközt, illetve módszert) is kidolgoztak annak számszerüsítésére, hogy egy adott terület éghajlati körülményei mennyire alkalmasak a különféle turisztikai tevékenységekhez. Léteznek egyszerübb eszközök, melyek kimenetei könnyen értelmezhetők a felhasználók számára, és széles réteget céloznak. Ugyanakkor néhány probléma vagy hiányosság is azonosítható az egyszerübb eljárásokkal kapcsolatban, ami jórészt az eszközök felépítéséből, struktúrájából adódik, valamint az is kétségbe vonható, hogy hitelesen használhatók a komplex turisztikai klímapotenciál jellemzésére.

Az ilyen eszközök problematikája sok esetben abban gyökerezik, hogy pusztán az objektív paraméterekre hagyatkoznak, és azokat a világ minden táján egyformán értékelik, ezáltal figyelmen kívül hagyják, hogy a különböző régiók lakosainak, illetve az odautazó turistáknak jelentősen eltérőek lehetnek a légköri környezettel kapcsolatos szubjektív megítéléseik. Ugyanis e környezet érzékelése és értékelése erősen szubjektív folyamat, ami azt jelenti, hogy különböző egyének vagy csoportok eltérően ítélhetik meg ugyanazokat a légköri viszonyokat. A problémakört felismerve felmerül az értékelö eszközök - helyi lakosokhoz és különböző éghajlati hátterü turista csoportokhoz történő - adaptálásának igénye.

A célszemélyek szubjektív megítéléseinek és viselkedési reakcióinak feltárása rendkívül komplex feladat, és felvételezésük túlnyomóan kérdőíves úton történik. Ennek során általában jól körülhatárolt piaci szegmensek (pl. adott korcsoport, nemzet, turisztikai tevékenységformát folytatók) mentén tanulmányozzák a szubjektív különbségeket. E ponton nyilvánvalóvá válik a turisztikai klimatológia szoros kapcsolata a humán-biometeorológia területével, amely a légköri környezetet leíró paraméterek emberi szervezetre gyakorolt hatásait vizsgálja, általában fiziológiai és újabban már pszichológiai szemszögböl is. Egyre inkább elfogadottá válik 
az az álláspont - amely egyúttal egy jelentős kihívást is jelent -, hogy hiteles humánbiometeorológiai és turisztikai klimatológiai értékeléseket csak komplexebb értékelö eszközökkel célszerü végezni, melyek révén lehetővé válik a szubjektív sajátosságok figyelembe vétele és az értékelés módszertanának adaptálása különböző embercsoportokhoz, illetve turisztikai tevékenységekhez.

Hazánk területére vonatkozóan a turisztikai klimatológiai mutatókon alapuló vizsgálatok száma egyelöre rendkívül alacsony, s az éghajlatváltozás turizmusra gyakorolt hatásának elemzése tekintetében is csak néhány kezdeti lépés történt. E vizsgálatokhoz kapcsolódóan megkíséreltem - hazánkban elsőként - adaptálni a hagyományos értékelő eszközöket a magyar lakossághoz, elsősorban azok termikus (a szubjektív hőérzetben megnyilvánuló) reakcióit figyelembe véve.

Disszertációmban a következő fó célokat tüzöm ki magam elé (a kutatási célok részletes ismertetését a 3.4. fejezet tartalmazza):

I. Az éghajlati viszonyok turizmusban betöltött szerepének ismertetése, és az értékelésére kidolgozott módszertan kritikai vizsgálata.

II. A turisztikai klímát értékelő módszertan fejlesztése és adaptálása a magyar lakossághoz.

III. Néhány kiemelt (hazai és európai) turisztikai desztináció klímapotenciáljának komplex értékelése.

IV. Magyarország jövőben várható turisztikai klímapotenciáljának elemzése.

Doktori munkám nem titkolt célja, hogy a téma széleskörü tárgyalásával és kutatásom eredményeivel elősegítsem a turisztikai klimatológia magyarországi megalapozását és szélesebb körű megismertetését, valamint módszertani újításokkal hozzájáruljak a tudományterület viszonylag kiterjedt nemzetközi tudásbázisához. 


\section{A téma felvezetése}

\subsection{Turizmus}

\subsubsection{A turizmus fogalma, jellemzöi, föbb formái}

A turizmus a világgazdaság egyik legnagyobb és legdinamikusabban fejlödő ágazata. 2015-ben a bruttó hazai termékhez (GDP) való közvetlen hozzájárulása világszinten 3,0\%, míg a teljes hozzájárulása 9,8\% volt. A turizmusban közvetlenül foglalkoztatottak aránya a teljes foglalkoztatás 3,6\%-át tette ki, míg a közvetett hatásokat is magában foglaló hozzájárulása a teljes foglalkoztatás 9,5\%-át adta (WTTC 2016).

2015-ben világszinten 4,4\%-kal (50 millió fövel) nőtt a külföldröl érkező turisták száma 2014-hez képest, és elérte az 1,184 milliárd föt. A 2009-es visszaesés óta 2015 a hatodik egymást követö év volt, amikor több mint 4\%-kal emelkedett a nemzetközi turistaérkezések száma. A világ leglátogatottabb régiója Európa, amely 2015-ben 5\%-os (28 millió fó) növekedést ért el az előző évhez képest, és megközelítette a 610 millió föt (2.1. ábra, UNWTO 2016a).
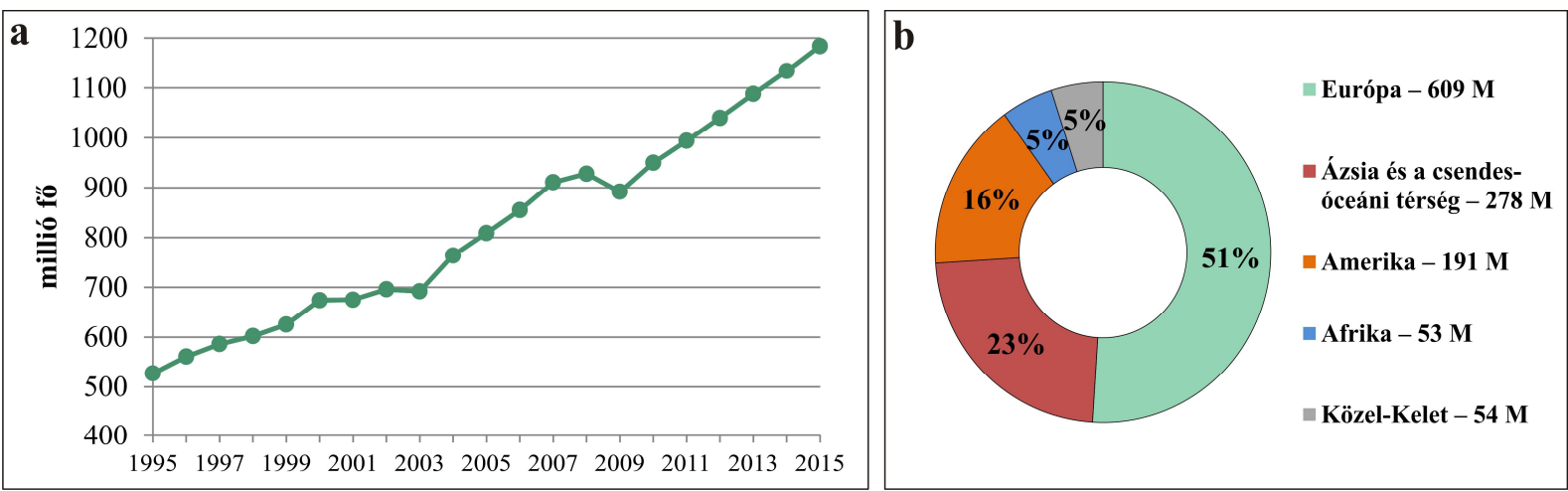

2.1. ábra: A nemzetközi turistaérkezések száma 1995 és 2015 között (a) és annak megoszlása az egyes régiók között 2015-ben (b) (UNWTO 2016a)

A turizmus hazánkban is a nemzetgazdaság kiemelkedően fontos szektora. A legutóbbi, a

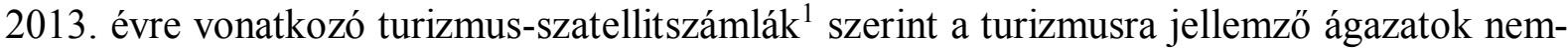
zetgazdasági bruttó kibocsátáson belüli aránya 5,6\%, a multiplikátor termelési hatásokat is figyelembe véve $9,0 \%$ volt. Az ágazatok összes hozzáadott értékének aránya a nemzetgazdaság egészéből $6,1 \%$ volt, ami a multiplikátorhatással együtt 9,8\%-ot jelent. A turizmus közvetlenül a nemzetgazdasági foglalkoztatottság 9,1\%-át, míg közvetlen és közvetett módon összesítve a 12,0\%-át adja (KSH 2017). 2015-ben csaknem 20,2 millió külföldi (egynapos és többnapos) turista érkezett Magyarországra, 17\%-kal többen, mint az azt megelőző évben (MTÜ 2016). 2015-ben a külföldiek 48 millió alkalommal utaztak Magyarország területére, 5,1\%-kal többen az elöző évinél (KSH 2016).

\footnotetext{
1 A turizmus-szatellitszámla a nemzeti számlák rendszerének egyik szatellitszámlája, összeállításának célja a turizmus keresleti és kínálati oldalának megfigyelése, valamint a turizmusszektor teljesítményének mérése, amellyel hozzájárul a nemzetgazdaság egészéhez. Megjelenik benne a látogatók utazáshoz kapcsoló áru- és szolgáltatáskereslete, a gazdaságon belül a turizmushoz kapcsolódó áru- és szolgáltatáskínálat, illetőleg a turisztikai kínálat más gazdasági tevékenységekre tovagyürüző hatása is (KSH 2017).
} 
A turizmus a gazdaság több ágazatát átölelő és a társadalom széles rétegét érintő tevékenység, életforma és fogyasztási szegmens. Sokrétű megfigyelési lehetőségéből és szerteágazó kapcsolatrendszeréből adódóan a turizmus csak számos szakágazat együttes teljesítményével értékelhető (KSH 2016). A turizmus fogalmának értelmezése az 1900-as évek folyamán a társadalmi jelentőségének növekedésével párhuzamosan állandó bővülésen, fejlődésen ment keresztül. A Lengyel (1986) által közzétett új turizmusdefiníció szerint a turizmus alatt „egyrészt az ember állandó életvitelén és munkarendjén (lakásán és munkahelyén) kívüli valamennyi helyváltoztatását és tevékenységét értjük, bármi legyen azok konkrét indítéka, időtartama és célterülete. A turizmus másrészt az ezzel kapcsolatos igények kielégítésére létrehozott anyagi-technikai és szervezeti feltételek, valamint szolgáltatások együttese". E definíciót az akkori Idegenforgalmi Világszervezet (WTO) rövidítve átvette és az Interparlamentáris Unióval együtt az 1989-es Hágai Nyilatkozatban közzétette: „A turizmus magában foglalja a személyek lakó- és munkahelyen kívüli minden szabad helyváltoztatását, valamint az azokból eredő szükségletek kielégítésére létrehozott szolgáltatásokat". Összhangban azzal, hogy a modern társadalom a munka és a szabadidő kettőssége köré szerveződik, Lengyel (1986) a turizmus két formáját különíti el: a hivatásturizmust és a szabadidő-turizmust. A hivatásturizmus magában foglalja a foglalkozással kapcsolatos helyváltoztatások során végzett szakmai és szabadidő-tevékenységeket. A szabadidő-turizmus az állandó lakáson kívül szabadidőben végzett és szabadon választott tevékenységek együttese, amelyeket az egyén változatosság iránti igénye motivál.

A nemzetközileg konzisztens turisztikai statisztikák összeállításához rendkívül fontos, hogy minden országban egységes fogalmakat és mérési módszereket használjanak, s így a turizmus gazdasági elemzése a nemzetgazdaságon belül (más ágazatokkal) és nemzetközi szinten (más országokkal) is összehasonlítható legyen. Például a statisztikai értékelésekhez módszertani és operatív ajánlásokat megfogalmazó UNWTO (2010) és a legfrissebb magyar turizmus-szatellitszámlákat bemutató KSH (2017) is egységes fogalmi keretet használ. A statisztikai összefüggésekben az előbbiekben ismertetett turizmusfogalmak továbbra is érvényesek abban a tekintetben, hogy a tartózkodás fó célja továbbra sincs meghatározva, ugyanakkor az utazás időtartamát és az utazó személyét illetően néhány megkötés áll fenn.

Az utazás (turisztikai statisztikákban trip) személy által megtett út bármilyen célból és időtartammal, amely során a személy elindul szokásos környezetéből egy másik helyre, míg viszsza nem tér a megszokott lakóhelyére. Körutazás esetén az utazás a különbözö helyszínek látogatásából tevődik össze. A látogató (visitor) az a személy, aki olyan helyekre utazik, amely a szokásos környezetén kívül esik, bármilyen célból teheti azt (üzleti út, szórakozás vagy más személyes szándékkal), ugyanakkor kevesebb mint 12 hónapot tartózkodik a meglátogatott helyen. Kitételként emelik még ki, hogy nem tartozik a látogatók körébe az a személy, aki a meglátogatott helyen végzett tevékenységéért javadalmazásban részesül. Turisztikai célú utazásnak (tourism trip) hívjuk a látogató által megtett szabadidős és/vagy üzleti céllal tett utat. A turista (tourist) olyan látogató, akinek az utazása eltöltött vendégéjszakát foglal magában, emiatt többnapos látogatónak (overnight visitor) is hívhatjuk őket. Ellenkező esetben kirándulókról vagy egynapos látogatókról (excursionist vagy same-day visitor) beszélünk (Lengyel 2004, UNWTO 2010, KSH 2017). Megjegyzendő, hogy a dolgozatom témakörében turisztikai klimatológia - hivatkozott publikációkban a fenti terminológia használata általában nem konzisztens. Ennek ugyanakkor semmilyen gyakorlati jelentősége nincsen, az ajánlások elsősorban a turisztikai statisztikák nemzetközi koherenciáját célozzák. 
Ennél a pontnál szót kell ejteni a Michalkó (2001) által bevezetett alternatív turizmusdefinícióról, amely a fenti meghatározások és „szabályok” által biztosított keretek helyett egy kevésbé merev, modernebb turizmuselméleti felfogást helyez előtérbe. Véleménye szerint napjaink egyre gyorsuló társadalmi-gazdasági változásainak köszönhetően a lakóhely, a munkahely és az ezeken kívülre irányuló, szabad helyváltoztatás fogalma és értelmezése részben meginogni látszik vagy nem teljesen körülhatárolható, s így nem jellemzi teljes körüen a világ turizmusának résztvevőit. Az új megközelítés szerint turizmusként olyan egyéni élményszerzéssel párosuló környezetváltozás értelmezhető, amely során átlépjük a mindennapi, rutinszerü térpályáinkat (általában a lakókörnyezet útvonalait), s a nem megszokott környezetbe kerülve a kiváltott élmények hatására szolgáltatások igénybevételére kerül sor, mellyel hozzájárulunk a helyi gazdaság bevételeihez (Michalkó 2001, 2008).

A turizmus fajtáit és formáit sokrétűsége miatt nehéz csoportosítani. Többféle kategorizálás született, ráadásul területenként is eltérő szempontok kerülhetnek előtérbe. A felosztások általában a meghatározó befolyásoló tényezőkön, így a helyváltoztatás indítóokain (motiváción), a környezet változatosságán, valamint a turizmus jelenségeire ható külső okok és hatások változásán alapulnak. Egy gyakran hivatkozott felosztás Bernecker (1962) munkájához füződik. A szerző az utazók motivációi alapján az alábbi turizmusfajtákat különítette el: pihenési célú turizmus (nyaralás, gyógyüdülés), kulturális célú turizmus (tanulmányi út, vallási turizmus), társadalmi célú turizmus (rokon- és barátlátogatás), sportturizmus (aktív és paszszív), gazdasági célú turizmus (üzleti turizmus, kiállítási és vásári turizmus) és politikaorientált turizmus (politikai rendezvények). A turizmusformák csoportosítása külső okok és hatások szerint történik (pl. eredet, résztvevők száma és életkora, szezonalitás, tartózkodás időtartama, szállásforma, közlekedési eszköz vagy az utazásszervezés módja szerint), és mindegyik kategórián belül többféle formát lehet elkülöníteni. Megemlítendő, hogy léteznek olyan összetett turizmusformák is, melyeket nem lehet egyértelműen valamely csoporthoz hozzárendelni.

\subsubsection{A turizmus által hasznosítható erőforrások}

A turizmus fogalmát többféleképpen is megközelíthetjük, viszont mindegyik meghatározás alapja, hogy létrejöttéhez és fennmaradásához földrajzi helyszín szükséges, amelyen a turisztikai tevékenységek létrejöhetnek. A turisták miközben felkeresnek területeket, minden esetben a helyszín által nyújtott valamilyen alkotóeleme(ke)t hasznosítanak. Amennyiben ezen alkotóelemek megjelennek a turisztikai termékek és szolgáltatások részeként, a terület erőforrásává válnak (Gómez Martín 2005). Napjainkban az erőforrások az élet több területén kiemelkedő jelentőséggel bírnak. A modern társadalmi elvárások egyre inkább az életszínvonal folytonos növekedését tüzik ki célul, ami a szükségletek kielégítése érdekében maga után vonja az erőforrások egyre növekvő kihasználását (Dávid et al. 2007). Hogy az adott területen milyen típusú erőforrások tudnak előtérbe kerülni, és azokat hogyan értékelik, az aktuális társadalmi szükségletek és normák (pl. divat) és azok változásai jelentősen befolyásolják (Perry 1997, Fagence and Kevan 1998, Gómez Martín 2005). A turizmus által hasznosítható erőforrások meghatározásánál fontos szempont a helyettesíthetőség kérdése is. Ennek hiánya, vagyis az egyediség jelentős értéknövelő tényezőnek számíthat, ugyanis a turisták jelentős része kifejezetten vágyik számukra újszerü, szokatlan élményekre (Dávid et al. 2007).

A turizmus erőforrásait a leggyakrabban a következő öt csoportba szokták elkülöníteni: természeti, kulturális, humán, infrastrukturális és pénzügyi erőforrások. Ezek közül kiemelt 
jelentőséggel bírnak a természeti erőforrások, mivel ezek valamilyen formában a legtöbb turisztikai termékbe beépülnek (Dávid et al. 2007). A természeti erőforrások közé sorolható gyakorlatilag minden olyan természeti képződmény vagy jelenség, ami a turisták számára vonzó lehet. Így például a terület felszíni formái, hidrológiai formakincse, tájképe, flórája és faunája, valamint az éghajlati viszonyai. Másfelől ide sorolandók olyan geológiai értékek, mint például a termálvíz vagy egy védett terület egyedi természeti kincse (de Freitas 2003, Gómez Martín 2005, Dávid et al. 2007, Scott et al. 2012).

Amennyiben egy terület felkeresésének a természetes vagy kulturális erőforrás megismerése (átélése) az elsődleges oka, ezen erőforrások turisztikai attrakcióként (vonzerőként) szolgálnak (Dávid et al. 2007). Az erőforrás attrakcióvá válása nem automatikus folyamat, ahhoz két alapvető feltételnek kell teljesülnie. Egyrészt szolgáltatások révén biztosítani kell az attrakció elérhetőségét vagy fokozni kell annak élményét (pl. megközelíthetőség, szállás- és vendéglátóhely biztosítása, közbiztonság, programok és rendezvények szervezése) (Fagence and Kevan 1998, Dávid et al. 2007). Másfelől az adott erőforrás köré vonzó arculatot kell kiépíteni. E folyamat marketingtevékenységet igényel, amely révén a fogyasztók megismerkednek a szolgáltatásokkal. Ehhez információforrásokra és reklámra van szükség, amely által pozitív kép (imázs) alakulhat ki bennük az adott helyszínről és az ott lévő értékről, ösztönözve az attrakció igénybevételére (Gómez Martín 2005, Dávid et al. 2007).

A természetes erőforrások egyik kulcsfontosságú típusa az éghajlat (klíma), amely egyben a turizmus egyik kiemelt erőforrása. E megállapításokat illetően szilárd konszenzus áll fenn a széles körü nemzetközi szakirodalom egészében (pl. Smith 1993, de Freitas 2003, Gómez Martín 2005, Matzarakis 2006, Rátz 2006, Dávid et al. 2007, Perch-Nielsen et al. 2010, Scott and Lemieux 2010, Amelung and Moreno 2012, Gössling et al. 2012, Scott et al. 2012, Rutty and Scott 2015). Az éghajlatot az Éghajlat-változási Kormányközi Testület (IPCC) ötödik értékelő jelentésének kiadványai - összhangban a Meteorológiai Világszervezettel (WMO) szükebb értelemben ,átlagos időjárásnak” definiálják. Tágabb vonatkozásban pedig az éghajlatot a légköri fizikai jellemzők átlagának és változékonyságának statisztikai összességeként értelmezhetjük, amelynek a vonatkozási időszaka hónapoktól ezer-millió évig terjedhet. Az éghajlatot kialakító állapothatározók (pl. léghőmérséklet, csapadék, szélsebesség) WMO szerinti átlagolása 30 évre vonatkozik (IPCC 2014a).

Természetesen a turizmus erőforrásai közül az éghajlati viszonyok csak egyetlen tényezőt jelentenek. Egy terület turisztikai fejlődése és sikeressége több erőforrás összességén alapul, de ezek közül kétségkívül kitüntetett szerepe van a természetes erőforrásoknak és azon belül az éghajlatnak.

\subsection{Turisztikai klimatológia}

\subsubsection{Az éghajlat mint a turizmus egyik kulcsfontosságú eröforrása}

Az éghajlat kiemelkedő jelentősége abban nyilvánul meg, hogy számos, elsősorban a természeti attrakciókra épülő turisztikai tevékenység alaperőforrásaként tekinthető, mivel döntően befolyásolja, hogy az adott területen létrejöhet-e valamilyen turisztikai tevékenység. A Smith (1993) által bevezetett terminológiát használva e tevékenységek általában ún. klímafüggőknek tekinthetők. (A nemzetközi szakirodalomban gyakran használják a „klímafüggő turizmus" kifejezést is.) Ide sorolandó például a nyaralóturizmus (strandolás, napozás), a téli 
sportturizmus, a szabadtéri vízi sportok (pl. vitorlázás) vagy az egészségturizmus (klímaterápiás célból). E tevékenységek létrejötte és sikeressége elsődlegesen egy vagy több időjárási vagy éghajlati állapothatározótól (pl. napfény, léghőmérséklet, hóborítottság) függ, melyek vonzereje a terület felkeresését generálja. Nagy szerepe van az éghajlati körülmények - látogatók által megszokott - szezonális stabilitásának (megbízhatóságának), amelynek ismeretében a látogatók azokban az időszakokban keresik fel a területet, amikor a számukra kedvező körülményekre számíthatnak.

Más esetben az időjárás vagy az éghajlat nem elsődleges erőforrás, hanem kiegészíti a többi alaperőforrást. Ilyen esetben nem közvetlenül generálják a turizmust, de elősegíthetik (vagy akadályozhatják) az adott tevékenység létrejöttét. Az éghajlat kiegészítő erőforrásként jelentkezik például a városnézés, a túrázás vagy akár a halászat esetében (Smith 1993, Fagence and Kevan 1998, Gómez Martín 2005). E tevékenységeket (vagy az ezekhez kapcsolódó turizmusfajtákat) időjárás- vagy éghajlatérzékenynek nevezzük (Smith 1993). A természeti attrakciókon alapuló tevékenységek mellett több - legalább részben szabadtéri - kulturális vonzerő esetében is jelentős szerepe van az időjárási vagy a klimatikus elemeknek (pl. szabadtéri múzeumok, előadások és koncertek, tematikus parkok felkeresése esetén) (Rátz 2006).

Az időjárási és a klimatikus viszonyok sok esetben nem elősegítik, hanem korlátozzák a turisztikai tevékenységeket, és kockázatokat rejtenek magukban (pl. egészségi, biztonsági veszély). Ez kihatással lehet a régió turisztikai kínálatára és az iránta lévő keresletre, valamint a látogatók személyes tapasztalataira és elégedettségére (Perry 1997, de Freitas 2003, Matzarakis 2006, Scott and Lemieux 2010, Scott et al. 2012). A legtöbb célterület rendelkezik egy ún. turisztikai potenciállal, ami a vizsgált terület fogadóképességének tárgyi feltételeit, lényegében a turizmus infrastruktúráját jelenti. E helyi feltételek elősegítik a meglévő vonzerők eredményes értékesítését. A vonzerők esetében szükséges, hogy azok feltárása és az azokat hasznosító turisztikai infrastruktúra kiépítettsége részben vagy teljesen kezdetleges legyen, de alkalmassá tehetők arra, hogy a térség fejlesztésének kulcsfontosságú bázisává váljanak (Michalkó 2008). Mivel egy terület éghajlata a turizmus által hasznosítható erőforrásnak tekinthető, a turisztikai potenciál egyik válfajaként bevezethető egy térség turisztikai klímapotenciáljának az értelmezése, melyet maga az éghajlat által nyújtott vonzerő és a korlátokkockázatok viszonya alakít. Megjegyzendő, hogy Michalkó (2008) szerint a turisztikai vagy idegenforgalmi potenciál kifejezés a hazai és nemzetközi idegenforgalmi szakirodalomban egyaránt elterjedőben van, átfogó értelmezésére és elméleti hátterének feltárására ez idáig nem került sor. Ehhez hasonlóan az általam vizsgált tanulmányokban a turisztikai klímapotenciálra vonatkozóan sem találtam átfogó meghatározást. De Freitas (2003) munkájában azonosítottam elöször e kifejezést, és ő érzékeltette sematikusan a jellegzetességeit. Napjainkra azonban már viszonylag széles körben használatossá vált.

A 2.2. ábra a turisztikai klímapotenciál alakulását mutatja egy képzeletbeli éghajlati tartományon (az optimálistól a szélsőséges körülményekig terjedően) (Perry 1997, de Freitas 2003). Az ábrán megnyilvánul a klimatikus viszonyok stimuláló vagy korlátozó szerepe. Az éghajlat által nyújtott vonzerő extrém esetekben alacsony, optimális körülmények során viszont megnő a jelentősége. Ezzel ellentétben a turista által vállalt (egészségügyi vagy biztonsági) kockázat szélsőséges klimatikus viszonyok esetén a legnagyobb, így az ilyen körülmények korlátozzák a tevékenységeket. Az összefüggésekböl az is látható, hogy meghatározható egy olyan küszöbérték (a valóságban inkább egy átmeneti zóna), amelyen túl a kockázatok fokozatos növekedése gyakorlatilag ellehetetlenítheti a tevékenységek folytatását, vagy a tu- 
risták elégedettsége oly mértékben csökken, hogy nem kívánják tovább folytatni tevékenységüket. A szélsőséges eseteken túl a küszöbértékek vagy -tartományok kijelölhetnek optimális éghajlati zónákat is az egyes tevékenységekre (Perry 1997, de Freitas 2003, Scott et al. 2012, Rutty 2014).

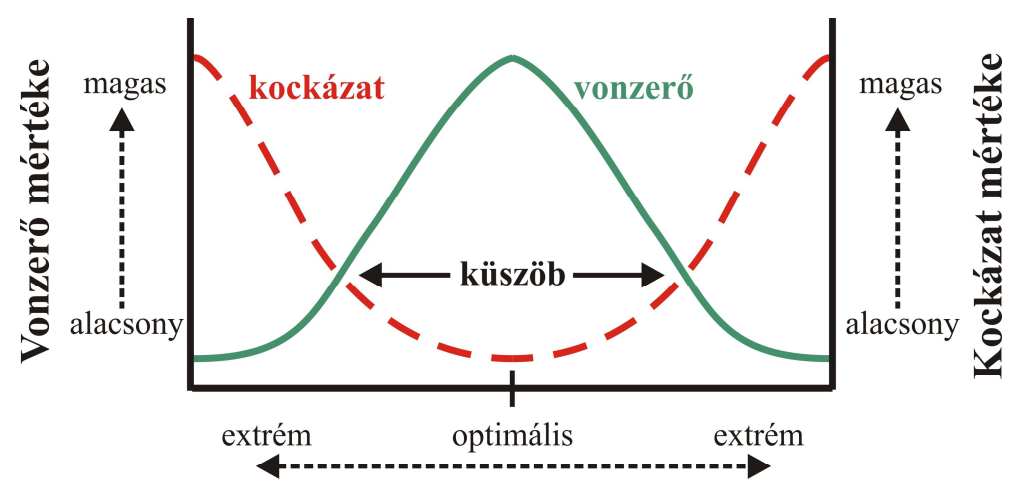

Klímatartomány

2.2. ábra: A turisztikai klímapotenciál reprezentálása sematikusan (Perry 1997 és de Freitas 2003). (Az összefüggések továbbgondolását a 2.4. ábra szemlélteti)

Az éghajlat elősegítő és korlátozó voltából következik, hogy sok esetben mint ,push" (toló) vagy „pull” (húzó) tényezőre hivatkoznak rá (Crompton 1979). A turisztikai irodalomban „pull” tényezőnek tekinthetjük mindazon hatásokat, melyek a desztinációkhoz köthetők, és vonzerőt (húzóerőt) gyakorolva elősegítik a fogadóterület felkeresését. Ide tartoznak például olyan erőforrások, termékek és szolgáltatások, mint az éghajlat, tengerpart megléte, szállás-, rekreációs és szórakozási lehetőségek, kulturális vonzerők. Ezzel szemben a „push” tényezők a kiindulási hely azon jellemzői, melyeket a turisták a terület (ideiglenes) elhagyásával elkerülni törekednek. Ide sorolhatók például a kellemetlen időjárási és éghajlati körülmények, a rossz közbiztonság vagy a nem megfelelő egészségügyi helyzet. A „push” kifejezést gyakran szociálpszichológiai fogalomként is azonosítják, és a turistákhoz kötődő pihenési, szórakozási, egészségkereső vagy nosztalgikus vágyakat foglalják össze (Crompton 1979, Fagence and Kevan 1998, Kozak 2002, Rátz 2006). Dann (1977) észrevétele szerint az utazókhoz köthető „push” tényezők logikailag és időben is a desztinációkhoz köthető „pull” faktorok előzményeinek, előfeltételeinek tekinthetők. Egy mindennapi példával élve: hiába tartogat a fogadóterület számos attrakciót a potenciális látogató számára, ha az utazó úgy dönt, hogy mégsem keresi fel a területet, például azért, mert odahaza is megfelelőek a klimatikus körülmények (vagyis nincs meg a ,push” hatás).

A ,push/pull” tényezők közös vonása, hogy mindkettő a turisták utazással kapcsolatos motivációját formálja, s ezáltal a célterület kiválasztását befolyásolja. Az éghajlat motivációt és a desztináció kiválasztását befolyásoló szerepét több tanulmány is vizsgálta, általában kérdöíves felmérés formájában. Bizonyítást nyert, hogy egy adott fogadótérség klimatikus viszonyai nagyfokú motivációt jelentenek a helyszín felkeresésére (Crompton 1979, Lohmann and Kaim 1999, Morgan et al. 2000, Kozak 2002, Hübner and Gössling 2012), valamint meghatározó szerepet játszanak a desztináció kiválasztásával kapcsolatos döntéshozatali folyamatokban (Lohmann and Kaim 1999, Hamilton and Lau 2005, Gössling et al. 2006, Scott et al. 2008, 2012, Moreno 2010a, Scott and Lemieux 2010). 
A klíma mint turisztikai erőforrás speciális, más erőforrásoktól kisebb-nagyobb mértékben eltérő jellegzetességekkel rendelkezik (Gómez Martín 2005, Scott et al. 2012, Rutty 2014). Az éghajlatra ún. szabad erőforrásként tekinthetünk, vagyis a kiegyenlített vagy fenntartható elosztásához nem igényel piaci vagy bármilyen szabályozási mechanizmust, így belöle konfliktus nem generálódhat (ellentétben például a vízzel vagy földdel). Az éghajlat megújuló erőforrás is, azaz a turisták, szolgáltatók vagy a gazdasági szektor által belőle „elfogyasztott" mennyiség nem befolyásolja a másokhoz való hozzáférését vagy a jövőbeli rendelkezésre állását. Továbbá az éghajlat kimeríthetetlen erőforrás, azaz az emberi beavatkozástól függetlenül sem csökken a jövőbeli mennyisége. Megjegyzendö, hogy a fenti jellegzetességeket a nem klímaspecifikus turisztikai szakirodalom, köztük közgazdaságtani vagy környezetgazdaságtani tankönyvek is gyakran taglalják (pl. Kahulits et al. 1997, Dávid et al. 2007, Peszeki 2011). E munkákban ún. szabad javakként hivatkoznak az éghajlati erőforrásra vagy annak egyes elemeire, például a napfényre. A szabad javak a természetben korlátlanul rendelkezésre álló, kimeríthetetlen és ingyenesen használható erőforrások, melyek nem emberi tevékenység eredményeképpen jönnek létre.

A klímaerőforrás további jellegzetessége, hogy nem tárolható és nem szállítható. Ez azt jelenti, hogy az adott helyre egy adott időpontban oda kell utazni, hogy a helyszínen (,in-situ”) rendelkezésre álljon. Végezetül a klíma eloszlása térben inhomogén és időben változékony. A térbeli inhomogenitásából következik a már említett sajátosság, hogy bizonyos területeken elősegíthetik, míg máshol gátolhatják a turisztikai tevékenységek létrejöttét vagy fenntartását (Gómez Martín 2005, Scott et al. 2012). Turisztikai szemszögből nézve a klíma időbeli változékonysága napi, szezonális és éves skálán is értelmezhető, ami egy sor előnyt vagy hátrányt hordoz magában, kihatva a turisztikai kereslet és kínálat ingadozására is.

Az éghajlat időbeli változékonyságával kapcsolatban ki kell térni a szezonalitás fogalmának a taglalására. A szezonalitás a turizmusipar egyik legproblémásabb, legösszetettebb, ugyanakkor kevésbé kutatott területe (Higham and Hinch 2002, Jang 2004). A szezonalitás a turizmus volumenének évi szisztematikus fluktuációja, a turisztikai tevékenységek általában egy adott időszakra összpontosuló koncentrációja.

A szezonalitás okait alapvetően két csoportra szokás bontani: természeti és intézményi (szervezeti). Természeti okként elsődlegesen maguknak az éghajlati változóknak (léghőmérséklet, csapadék, szélsebesség, hóborítottság stb.) évi változékonysága tehető felelőssé, mind a fogadó-, mind a forrásterületre vonatkozóan. Az éghajlat évi változékonysága viszonylag stabil és kiszámítható. Az intézményi szempontokat alapvetően a társadalmi normák, szokások és a divat szabják meg, így például a vallási ünnepek ideje, az iskolai szünetek, szabadságolások (hivatalok, ipar, mezőgazdaság) vagy a sportesemények (pl. olimpiai játékok) időzítése. Ez utóbbiak is viszonylag stabilak, ugyanakkor döntéshozatal útján egy bizonyos szintig módosíthatók (Higham and Hinch 2002, Getz and Nilsson 2004, Amelung et al. 2007).

A szezonalitás az ingadozó kapacitás következtében kihathat egy sor problémára, például a látogatószám, társadalmi aktivitás, kereslet és kínálat, profit és a foglalkoztatottság alakulására. Ezeken felül a csúcsidőszaki koncentráció környezeti következményeket is generálhat, amely egyfajta szezonális terhelést okozhat (gyakran a helyi lakosság számára is). Környezeti problémák jelentkezhetnek például a vízellátás, a hulladékkezelés, a közlekedés és a közösségi szolgáltatások területén. A szezonalitás előnyeként kiemelhető, hogy a csúcsszezoni időszakon kívül valamelyest fellélegezhet és megújulhat a terület gazdasági, társadalmi és környezeti szempontból is (Getz and Nilsson 2004, Amelung et al. 2007). 
A szezonalitás problémája azokon a területeken a legjelentősebb, ahol a turisztikai kínálat eleve kevésbé diverzifikált (csak az év kis részében dominál) és/vagy nagyban támaszkodik az éghajlatra és/vagy a változó klimatikus körülményekhez való adaptációs lehetősége csekély. A legjelentősebb probléma ott mutatkozik, ahol egyetlen, ráadásul klímafüggő tevékenység dominál, például tengerparti turizmus, téli sportturizmus, néhány vízi és extrém sportra épülö turizmus esetében (Gómez Martín 2005).

A szezonalitás problémakörét leginkább annak negatív következményei felöl közelítik meg, és hatásának csökkentésére különböző megoldásokat javasolnak. Legoptimálisabb megoldási lehetőség a turisztikai kínálat diverzifikációja, vagyis kiterjesztése vagy adaptálása különböző klimatikus körülményekkel jellemezhető időszakokra (több évszakra). Amennyiben lehetőség van rá, célszerü új, egész évben alkalmas tevékenységeket bevezetni. Megoldási lehetőség lehet az éghajlaton kívül valamely más erőforrás keresése és hasznosításának kiépítése. Nyitni lehet más piaci szegmens felé is (idősek, konferenciaturizmus) (Gómez Martín 2005, Amelung et al. 2007).

A turizmus és az időjárási vagy éghajlati viszonyok közötti kapcsolatrendszer mibenlétét, mechanizmusait vizsgáló interdiszciplináris tudományterület a turisztikai klimatológia. Pontos tudományági besorolása egyelőre várat magára, de alapvetően az alkalmazott klimatológia egyik ágazatának tekinthető. Legszorosabb összefüggésbe a humán-biometeorológia vagy humán-bioklimatológia tudományával hozható, kialakulásakor is annak ismeretanyagából merítkezett. A terület sokszínűségét az is mutatja, hogy az éghajlat és a turizmus közötti kapcsolatrendszer megismeréséhez a humán-biometeorológián kívül az általános meteorológia és klimatológia, a turizmuselmélet, a humánerőforrás-menedzsment, a fiziológia és a pszichológia nyújtotta ismeretek is szükségesek (Mieczkowski 1985, de Freitas 2003, de Freitas et al. 2008). A témakört megalapozó jelentősebb átfogó leírásoknak Mieczkowski (1985), de Freitas (1990), Perry (1993, 1997), Smith (1993), majd később de Freitas (2003), Gómez Martín (2005) és Scott et al. (2012) munkái számítanak. Magát a „turisztikai klimatológia” tudományterületi elnevezést de Freitas 2003-as munkájában azonosítottam először, majd ezután egyre szélesebb körben elterjedtté vált.

A tudományterület ugyan fiatal, de az éghajlati viszonyok turizmusra gyakorolt hatása már hosszú évszázadok óta nyilvánvaló. Az utazások egyik legjelentősebb válfajaként már egészen az ókor óta a kedvező, kellemes időjárási és klimatikus körülmények iránti vágyakozás szolgált. A 19. század végéig az utazások időzítése inkább időszakos, szezonális volt. Egyfelől az elit társadalmi rétegek a városok területéről időszakosan a kevésbé terhelőbb, tisztább és fertőzésmentesebb vidéki területekre utaztak (tengerpartok, szigetek, hegyvidékek, zöld területek). Másfelől szintén a jobb módúak gyakran célzottan klímaterápiás vagy gyógyászati célokból utaztak, hogy a klíma (pl. tengeri, magashegyi) vagy a termálvíz gyógyító hatását felhasználják egészségük, általános kondíciójuk javítására. Ez utóbbi időszakos turistaforgalom egyre stabilabbá és megszokottá vált, s a 19. század folyamán sorra alakultak ki az állandó üdülő- és (gyógy)fürdőhelyek a tengerparti területeken (kezdetben Nagy-Britanniában, Franciaországban és Németországban) vagy a termálvízforrások közelében. A szezonális „áradat” kiszolgálására (és egyre inkább azoknak is, akik már nem gyógyító célokból utaztak) szolgáltatásokat kellett biztosítani (szállás, vendéglátás). Ezzel párhuzamosan ki kellett alakítani az üdülőhelyi régió általános vonzerejét különféle természetes és mesterséges attrakciók biztosításával. E két tevékenység végeredményben elvezetett a turizmusipar kialakulásához. 
A 20. század folyamán az utazások a szezonális „levegőváltozás”, a gyógyító és klímaterápiás céloktól egyre inkább a kikapcsolódási, szórakozási és élvezeti lehetőségek keresése irányába tolódott. A célterületet tekintve pedig meghatározóvá vált a tengerparti üdülőhelyek felé történő orientáció, amelyben hatalmas szerepe volt a 20. században jellemző trendeknek, elsősorban a napozás és napbarnítottság iránti hóbortnak, valamint a napozás egészség- és közérzetjavító hatásának. Az üdülés egyre távolabbi helyszínekre és egyre szélesebb társadalmi rétegek számára állt rendelkezésre (Perry 1993, 1997, Fagence and Kevan 1998).

A klimatikus elemek utazásban betöltött szerepe tehát évszázadok óta meghatározó tényező, és a turizmus kialakulásában is meghatározó szereppel bírt. Ugyanakkor az 1980-as évek elejéig csekély tudományos érdeklődés mutatkozott arra, hogy az éghajlati körülmények és feltételek turizmusra gyakorolt szerepét és a kettő közötti kapcsolatrendszert vizsgálják. A turisztikai kutatások akkoriban a turizmus volumenének meredek emelkedése miatt annak gazdasági és társadalmi hatásaira fókuszáltak (Scott et al. 2012). A csekély érdeklődés oka lehetett az is, hogy egyrészt túlságosan magától értetődőnek adódott a klíma és a turizmus közötti kapcsolatrendszer, és ezért szükségtelennek tartották annak vizsgálatát (de Freitas 2003). Másrészt az 1980-as évekig az éghajlatra többé-kevésbé mint stabil, kevésbé változó és kiszámítható tényezőre tekintettek, amelyre az emberiség csekély befolyással lehet, és a turisztikai keresletre gyakorolt hatása is elhanyagolható. Az 1980-as években az időjárási szélsőségekkel és a globális klímaváltozással kapcsolatos kérdéskör előtérbe kerülése jelentős szemléletváltozást hozott, s a kutatások számának jelentős növekedését okozta (Amelung et al. 2007, Moreno and Amelung 2009, Moreno 2010a, Scott et al. 2012).

\subsubsection{Turizmus és éghajlatváltozás}

Az IPCC 2014-es értékelő jelentése szerint az éghajlati rendszer melegedése egyértelmü. Az északi féltekén az 1983 és 2012 közötti időszak valószínüleg a legmelegebb 30 éves periódus volt az elmúlt 1400 évben (közepes megbízhatósággal). A globális átlagos felszínközeli (szárazföldi és tengerfelszíni) hőmérséklet alapján 1880-tól 2012-ig 0,85 ${ }^{\circ} \mathrm{C}$-os $(0,65-1,06$ $\left.{ }^{\circ} \mathrm{C}\right)$ melegedés detektálható. A jelentés rendkívül valószínűnek tartja, hogy a 20. század közepétől megfigyelt melegedésnek az antropogén eredetü üvegházgázok a legfőbb okozói. Az üvegházhatású gázok folytatódó kibocsátása további melegedést fog okozni, s nagyon valószínü, hogy a nagy csapadékkal járó események egyre intenzívebbé és gyakoribbá válnak, az óceánok felmelegedése és savasodása, valamint a globális tengerszint emelkedése pedig folytatódni fog. Az elmúlt évtizedek megfigyelései szerint az éghajlatváltozás az egész világon hatással van a természeti és az ember által létrehozott rendszerekre, a meglévő kockázatokat felerősíti, és új kockázatokat hoz létre (IPCC 2014b).

Európában a megfigyelt tendenciák és a jövőre vonatkozó projekciók regionálisan eltérö változásokat mutatnak a hőmérsékletre és a csapadékra vonatkozóan (nagyfokú megbízhatósággal). A hőmérséklet tekintetében egész Európában emelkedés valószínűsíthető, a csapadékban pedig Észak-Európában növekedés, míg Dél-Európában csökkenés várható. A hőmérsékleti szélsőségek és a heves csapadékesemények gyakoriságának jelentős emelkedésére számíthatunk (magas megbízhatósággal). A klímaváltozás nagyon valószínű, hogy növeli a hőhullámok gyakoriságát és intenzitását, különösen Dél-Európában (magas valószínüséggel). Ennek kedvezőtlen hatásai továbbgyürüznek például az egészségügy, a mezőgazdaság, az energia, a közlekedés és a turizmus szektorokra (Kovats et al. 2014). 
Az éghajlat mint turisztikai erőforrás változása számos közvetlen vagy közvetett hatással járhat a turizmusiparra és a turisztikai desztinációkra. A turizmus a mezőgazdaság, energia, biztosítás és közlekedés szektorhoz hasonlóan jelentősen érzékeny a klímaváltozás hatásaira. Kitüntetett ugyanakkor abban a tekintetben, hogy a klímaváltozás indirekt módon számos egyéb környezeti erőforrást vagy attrakciót is befolyásolhat, s ennek hatása tovább- vagy viszszagyürüzhet a turizmus szektorra (UNWTO 2008, Moreno and Amelung 2009, Gössling et al. 2012, Scott et al. 2012, IPCC 2014c).

A turizmusra gyakorolt indirekt hatások javarészt negatív következményekkel járhatnak. Elsősorban a tengerparti és hegyvidéki területeket, valamint a szigetvilágot érintik érzékenyen, de városi területeken is jelentősek lehetnek. Az óceánok szintjének emelkedése, az erózió, az extrém időjárási események gyakoriságának növekedése károsan befolyásolhatja a tengerparti és a városi turizmus infrastruktúráját, illetve a területek természetes vonzerejét. $\mathrm{Az}$ emelkedő hőmérséklet és a hóborítottsági viszonyok megváltozása rövidítheti a téli (sí)turizmus hosszát és a síközpontok müködési időszakát. A városi területeken kialakuló hőterhelés és a szélsőséges időjárási események károsan befolyásolhatják a turisták egészségét, közérzetét és a területtel való elégedettségét. A csapadékmennyiség változása hatással bír a vízkészletekre és azok elérhetőségére, illetve befolyásolja az élelmiszer-biztonságot. A klímaváltozás hatással van az élővilág termelékenységére, a biodiverzitásra, s így az ökoturizmusra. Az óceánsavasodás és az óceánok vízszintjének emelkedése a korallzátonyok és a halállomány csökkenését okozza. Az éghajlat változása elősegíti a járványok megjelenését és terjedését a fertőző betegségeket terjesztő rovarok és rágcsálók elterjedésének függvényében, ami a turizmus tér- és időbeli elterjedésére is hatást gyakorol. A klímaváltozás befolyásolja a mezőgazdaság termelékenységét is, amely kihat például a borturizmusra. Valamennyi fenti jelenség továbbgyürüzik a turizmusiparba (pl. az anyagi kiesés, a kárelhárítási, kárenyhítési költségek és a magasabb üzemeltetési költségek révén).

A 2.2.1. fejezetben vázoltam, hogy az éghajlat meghatározza a turisztikai tevékenységek elhelyezkedését és a turisztikai szezon hosszát. Ebből kifolyólag az éghajlat változása módosíthatja a klímaerőforrás globális tér- és időbeli eloszlását, amelyet a klímaváltozás direkt hatásaként azonosít a szakirodalom. A turisztikai klimatikus viszonyok eltolódása maga után vonhatja a belföldi és a nemzetközi turistaforgalom tér- és időbeli megváltozását, ami kihatással lehet a turisztikai desztinációk versenyképességére (Scott et al. 2004, 2012, UNWTO 2008, IPCC 2014c, Kovats et al. 2014, Rutty and Scott 2014).

Számos tanulmány vizsgálta, hogy a turisztikai klímapotenciál a 21. század folyamán miként változhat meg, és legnagyobb hányaduk hasonló eredményre jutott. A magasabb földrajzi szélességeken fekvő területeken (Európa és Amerika északi részein, vagyis például a skandináv országokban, Nagy-Britannia és Kanada területén) nyáron a klimatikus viszonyok kedvezőbbé válása valószínüsíthető, s ez az átmeneti évszakokra is kitolódhat. E tendenciából következően az is lehetséges, hogy az északi területek belföldi turizmusa és a nemzetközi turistaérkezések száma növekedhet a nyári időszakban. Alacsonyabb szélességeken (pl. a Mediterráneum területén, a Karibi-térségben vagy Mexikóban) viszont a turizmus éghajlati feltételei kedvezőtlenebbé válhatnak nyáron. Ugyanakkor az átmeneti évszakokban (tavasszal és ősszel) a klimatikus viszonyok javulása valószínűsíthető a déli területeken. Jelentősebb változások a 21. század második felében valószínúek (Morgan et al. 2000, Scott and McBoyle 2001, Scott et al. 2004, Hamilton et al. 2005, Amelung and Viner 2006, Amelung et al. 2007, 
Nicholls and Amelung 2008, Hein et al. 2009, Perch-Nielsen et al. 2010, Amelung and Moreno 2012, Amengual et al. 2012).

A turisztikai klimatikus viszonyok várható tendenciáit tekintve tehát jelentős az egyetértés, viszont kevés egyelőre az ismeretünk arra vonatkozóan (mind a kutatások száma, mind az információk minősége alapján), hogy a klímaváltozás a turizmusipart hogyan befolyásolhatja, és az egyes desztinációk hogyan és milyen eszközökkel tudnak alkalmazkodni a klímaváltozás elkerülhetetlen hatásaihoz. Az alkalmazkodás szolgálhatja egyrészt a kockázatok minimalizálását, de az esetleges lehetőségek hasznosítását is.

A témán belül jelentős kihívást jelent az is, hogy nem ismertek a turisták viselkedési reakciói a klímaváltozás révén megváltozó viszonyokkal kapcsolatban. Az bizonyos, hogy a turizmus szereplői közül a turisták alkalmazkodóképessége a legnagyobb, ugyanis a helyszínt, az időzítést, az utazás gyakoriságát vagy az utazás során végzett tevékenységet (pl. tengerparti fürdőzés vagy városnézés) is elvileg rugalmasan tudják alakítani. Természetesen ez az anyagiak, a rendelkezésre álló idő és az információszolgáltatás függvénye. A turisztikai szolgáltatók adaptációs lehetőségei ezzel szemben jóval korlátozottabbak, különösen a nagy, helyhez kötött beruházások esetében (pl. üdülökomplexumok) (UNWTO 2008, Gössling et al. 2012, Scott et al. 2012, Rutty 2014).

A turisták viselkedési reakcióinak feltérképezése érdekében kérdőíves vizsgálatok indultak meg az elmúlt néhány évben. A felmérések gyakran arra irányulnak, hogy a turisták által optimálisnak, elfogadhatónak vagy éppen elfogadhatatlannak tartott klimatikus körülményeket azonosítsák. E vizsgálatok közül néhány megkérdőjelezte azt az elöbbiekben is említett, sokak által elfogadott kutatási eredményt, hogy a mediterrán térség „túl forróvá” válik, és esetlegesen a nemzetközi turistaérkezések száma csökkenhet. Például Rutty and Scott (2010) szerint nem valószínü, hogy a következő néhány évtized során a mediterrán térségben az éghajlati feltételek kedvezőtlenebbé válhatnak. Kérdőíves felmérésüket észak-európai egyetemistákkal végezték, s összevetették a turisták városi és tengerparti turizmusra vonatkozó klimatikus értékeléseit a térségben várható jövőbeli éghajlati viszonyokkal. Moreno and Amelung (2009) hasonlóan arra a következtetésre jutott egy turisztikai klímaindex által jelzett tendencia alapján, hogy a következő ötven évben a mediterrán térség éghajlati feltételei csak kismértékben változhatnak, és Európa legjelentősebb nyári üdülőterülete maradhat. Északeurópai utazókkal végzett kérdőíves felmérés alapján Moreno (2010a) azt találta, hogy a legtöbb turista még akkor is elutazna a mediterrán térségbe, ha az általuk a tengerparti turizmushoz kötött ,ideális időjárási körülmények” a klímaváltozás következtében a küldő területen is megtalálhatók lennének. E három példa is jelzi, hogy a turisták szubjektív értékelése nem feltétlenül van összhangban a tisztán objektív alapú eredmények által jelzett tendenciákkal. A turisták értékelésének és reakcióinak megértése elengedhetetlen a klímaerőforrás globális földrajzi és időbeli elterjedésének vizsgálatában és a változások elemzésében (Gómez Martín 2005, 2006, de Freitas et al. 2008, Scott et al. 2008, Amelung and Moreno 2012, Gössling et al. 2012). A jelenlegihez képest ugyanakkor jóval szélesebb körü vizsgálatsorozat szükséges a jövőben mind az éghajlati információk által jelzett tendenciák, mind a turisták reakcióinak megismerése céljából. 


\subsubsection{Időjárási és éghajlati információk, szerepük a turizmusban}

A turisztikai klimatológiai és a klímaváltozást taglaló kutatások időjárási és éghajlati információkat igényelnek a turisztikai célterületek éghajlati feltételeinek alakulásáról és annak változásáról. Ezen információk elengedhetetlenek a turizmus szektor szereplői, így a turisták, a turizmusfejlesztők és szolgáltatók, valamint a kormányzati szervek számára. A turisztikai szolgáltatóknak az éghajlati információk ismeretében lehetőségük nyílik például a szezonalitás kockázatának csökkentésére, ha például növelni tudják a kínálatot a csúcsforgalmi időszakon kívül, míg a turisták a megfelelő helyszínt és időpontot, illetve tevékenységformát tudják optimálisabban kiválasztani.

Az időjárási és éghajlati információk mérések, megfigyelések vagy időjárási és éghajlati modellek által származhatnak. A 21. század technikai forradalma a turisztikai információk terjesztésében is jelentős áttörést hozott. A nyomtatott anyagok mellett elektronikus dokumentumok, internetes források, audiovizuális tartalmak, mobilapplikációk, valamint intelligens (smart) eszközök is rendelkezésre állnak. Az új technológiákkal szélesebb rétegeket lehet megszólítani, nagyobb és személyre szabottabb információtartalmat lehet átadni jóval gyorsabban. Az információ nagyobb mennyisége lehetővé teszi, hogy a szolgáltatásokat össze lehessen hasonlítani, s így a döntéshozatal nagyobb autonómiával rendelkezzen (UNWTO 2016b).

Az időjárási és a klímainformációk időbeli terjedelme a néhány órás előrejelzésektől (nowcasting), a rövid távú és középtávú időjárás-elörejelzéseken (néhány nap) keresztül a néhány évtizedre vonatkozó mérési adatokig vagy éghajlati projekciókig tart.

A 2.3. ábra a különböző időtávú meteorológiai és éghajlati információk (hosszabb távú adatok, időjárás-elörejelzések, pillanatnyi információk) turisták döntéshozatalában betöltött szerepét illusztrálja az utazás előtti és az utazás alatti időszakokban. A hosszú távú éghajlati információk leginkább a célterület kiválasztásában és az ott folytatandó tevékenységek (pl. strandolás, túrázás, városnézés) tervezésében, valamint az utazás időzítésében (pl. melyik évszakban vagy hónapban utazzanak) játszanak szerepet.

\section{Utazástervezés}

\section{Utazás}

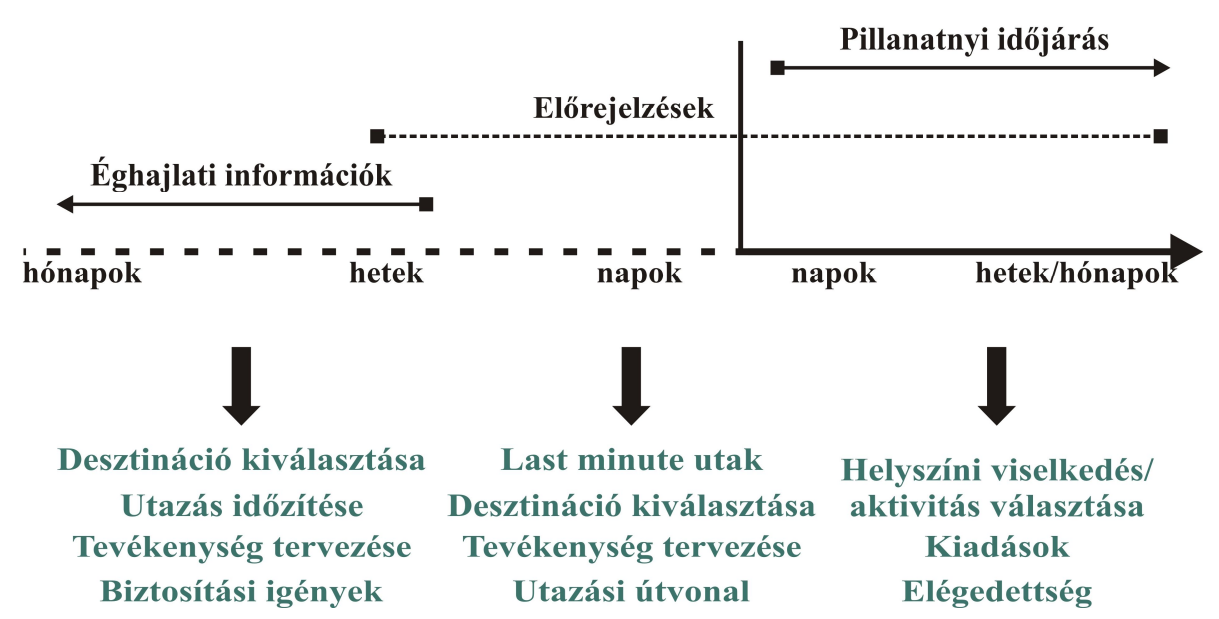

2.3. ábra: Meteorológiai és éghajlati információk szerepe a turisták döntéshozatala során (Scott and Lemieux 2010) 
A rövidebb távú időjárás-előrejelzések hatása részben az előzőhöz hasonló. Ugyanakkor különösen a nowcasting elörejelzések esetenként a konkrét utazási útvonal kiválasztását is befolyásolhatják (pl. a havazással érintett útszakasz elkerülése), valamint meghatározhatják a közlekedési eszköz típusát, továbbá a ruházat kiválasztását is. Emellett jelentős szerepe lehet az utazás programtervének összeállításában (az egyes tevékenységek időzítése a várható időjárás figyelembevételével), valamint főként a belföldi last minute utazások (melyek az utazás időpontja előtt nem sokkal kerülnek értékesítésre) tervezésében.

A látogatás alatti pillanatnyi időjárás befolyásolhatja a tevékenységek típusát és ütemezését, valamint a célterületre vonatkozó általános elégedettséget. Többnapos kellemetlen időjárás - föként, ha valamilyen alternatív, áthidaló (pl. beltéri) tevékenységet nem tud a terület biztosítani - elégedetlenséget, kellemetlenséget szülhet, $\mathrm{s}$ esetlegesen a nyaralás lerövidítését vagy egy másik célterületre való utazást vonhatja maga után (Gómez Martín 2005, Scott and Lemieux 2010).

A turizmusfejlesztők és szolgáltatók, valamint a célterületeken dolgozók a hosszabb távú (pl. harmincéves) klímainformációkat felhasználhatják számos infrastrukturális tervezéskor (pl. üdülöhelyek elhelyezkedése, létesítmények tervezése, beruházási döntések, építés ütemezése, biztosítási igények). Egyre nagyobb jelentősége van a hosszabb távú időjáráselőrejelzéseknek és az éghajlati projekcióknak a klímaváltozás hatásainak elkerülésében vagy a hozzájuk való alkalmazkodásban (pl. beruházási döntések, bevételek alakulása, szezonális foglaltság előrejelzése, biztosítási igények alakulása, marketingtevékenységek, munkahelyteremtés, veszélyhelyzeti felkészültség). Az időjárás-elörejelzések befolyásolhatják többek között a szabadtéri tevékenységek tervezését (pl. kirándulásszervezés), a különböző karbantartások ütemezését és az alkalmazottak beosztását. A pillanatnyi időjárásnak a kockázatkezelésben (szélsőséges időjárási események hatása, lavinakockázat), az operatív müködésben (pl. hóágyúzás szükségessége) és számos marketingtevékenységben (pl. a vonzó klimatikus körülmények vagy események webkamerás felvételekkel való reklámozása) van szerepe. A már hazánkban is elterjedt különféle időjárás-biztosítások (jóidő-biztosítások) kialakítása is éghajlati vagy időjárási információt igényel, amely lehetőleg az adott tevékenységtípushoz (pl. tengerparti üdülés) illeszkedik, és a turisták hosszú távú tapasztalataival is összhangban van.

Mindmáig kevés kutatás foglalkozott azzal, hogy milyen éghajlattal kapcsolatos információk szükségesek a turisták és a szolgáltatók számára, és melyek befolyásolják leginkább a turisták utazástervezési folyamatát (de Freitas 2003, Gössling et al. 2006, 2012, Scott et al. 2008, 2012). A turisztikai klimatológiai információk szolgáltatásakor kulcsfontosságú annak az eldöntése, hogy mely és mennyi meteorológiai vagy klimatológiai paraméter (pl. léghömérséklet, csapadék, szélsebesség, felhőzet, hóborítottság, UV-sugárzás) szükséges és elégséges a klimatikus viszonyok értékelésére. Nehézséget okoz az is, hogy a különféle turisztikai célterületek és tevékenységformák éghajlati feltételeinek jellemzése más és más mennyiségü és jellegü paramétert igényel. Újabb kérdést vet fel, hogy amennyiben több paraméter is releváns az adott területen vagy az adott tevékenység esetében, ezek hatását külön-külön vagy együttesen érdemes jellemezni. Újabb problémába ütközik, hogy mit tekintünk - akár az egyes paraméterek, akár ezek összetett hatása szintjén - az egyes tevékenységek szempontjából optimális, elfogadható vagy éppen alkalmatlan időjárási vagy klimatikus körülménynek, s ezek hogyan hozhatók összefüggésbe a turisták tényleges tapasztalataival és értékeléseivel (Matzarakis 2006, Scott et al. 2008). 


\subsubsection{Az éghajlati információk turisztikai értékelésének alapelvei}

Az elmúlt évtizedekben egyre nagyobb hangsúly fordítódott olyan értékelő eszközök kifejlesztésére, melyek számszerüsíteni tudják az éghajlati körülmények hatását abból a szempontból, hogy azok mennyire alkalmasak a különféle turisztikai tevékenységek tekintetében. A korai éghajlati indexek kidolgozása még nem speciálisan turisztikai klimatikus célokból történt, hanem az alkalmazott klimatológia és a humán-biometeorológia akkori ismeretanyagából merítkezett. Az 1980-as évek elejétől fejlesztettek ki speciálisabb, a turisztikai klíma értékelésére egyre alkalmasabb mutatókat.

Abegg (1996) és Matzarakis (2006) a turisztikai klimatikus célokra is alkalmazható eszközök három csoportját különítette el: elemi, bioklimatikus (termikus) és kombinált (összetett) mutatók. Az elemi indexek általában csak egy-egy meteorológiai változó (pl. léghőmérséklet, napfénytartam, csapadék) vagy ennek egyszerü kombinációjára épülnek, s a mai, korszerü tudásunk szerinti termofiziológiai relevanciával nem rendelkeznek. Ez azt jelenti, hogy nem veszik figyelembe az emberi szervezet hőszabályozási mechanizmusait, s így nem fejezik ki megfelelően a légköri paraméterek emberi szervezetre (egészségre és közérzetre) gyakorolt termikus hatásait.

Egyik legismertebb elemi mérőszám az ún. sörkerti napok száma, amely alatt egy időszak (év, hónap) azon napjainak a számát értjük, amikor a helyi 21 órakor mért léghömérséklet 20 ${ }^{\circ} \mathrm{C}$ felett alakul. Egy további példa a turisztikai klimatológiai szakirodalomban gyakran hivatkozott Davis (1968) által megalkotott klímaindex, amely a (jelentős turistaforgalommal bíró) nyári időszakban uralkodó átlagos maximum-hőmérséklet, napfénytartam és csapadékmenynyiség egyszerü súlyozott összegén alapul:

$$
I=18 \times T_{\max }+20 \times S-0,276 \times R+320 .
$$

Az összefüggésben $T_{\max }$ az átlagos napi maximum-hőmérséklet $\left({ }^{\circ} \mathrm{C}\right), S$ az átlagos napi napfénytartam (óra), $R$ a teljes csapadékmennyiség $(\mathrm{mm})$ a június és augusztus közötti időszakra vonatkozóan.

Az elemi indexek említett hiányosságát hivatottak pótolni a bioklimatikus (termikus) indexek, mely csoporton belül elkülöníthetünk ún. empirikus (egyszerü), valamint komplexebb, ún. racionális (humán-energiaegyenlegen alapuló) indexeket. Az empirikus bioklimatikus mutatók kevés meteorológiai változót igényelnek, mérésük vagy beszerzésük nem ütközik nehézségekbe, és egyszerü, tapasztalati összefüggések révén könnyen számolhatók. Az empirikus indexek csoportjába sorolhatók az ún. „,windchill típusú” indexek, melyek a magas földrajzi szélességü területeken az alacsony hőmérséklet és nagy szélsebesség együttes hatásán keresztül jellemzik a hőérzetet és a szervezetre gyakorolt hidegstressz mértékét a konvektív hővesztés révén létrejövő kihülés vagy (el)fagyás kockázatával együtt (Steadman 1971, Dixon and Prior 1987). Az alacsony földrajzi szélességeken a Humidex (Masterton and Richardson 1979) vagy a Heat index (Steadman 1979, Rothfusz 1990) nevü empirikus mérőszám szolgál egy elterjedt mutatóként a termikus stressz és a hőérzet számszerüsítésére. Ezeken az általában forró és fülledt viszonyokkal bíró területeken a magas léghőmérséklettel kombinálódó magas légnedvesség akadályozhatja az evaporatív hővesztést, s ezáltal extrém meleg terhelést okozhat. A Humidex és a Heat Index ezt a hatást hivatottak számszerüsíteni. 
$\mathrm{Az}$ empirikus indexek egy részét napjainkban is használják a meteorológiai gyakorlatban (pl. az USA, Kanada és Ausztrália területén). Hátrányuk ugyanakkor, hogy csak szélsőséges körülmények között használhatók. Ezenfelül az elemi indexekkel ellentétben ugyan már van termofiziológiai relevanciájuk, de mai ismereteink szerint ez már nem kielégítő. Nem veszik számításba ugyanis az emberi szervezetre gyakorolt termofiziológiai hatásokat számszerüsítő legfontosabb paramétereket, így például a szélsebességet és a rendkívül nagy jelentőséggel bíró hőhatású sugárzási komponenseket (Mayer and Höppe 1987, Jendritzky 1993, Mayer 1993, VDI 1998, Ali-Toudert 2005). A hőhatású sugárzás kulcsfontosságú paraméter a humán-biometeorológia területén, ugyanis szabadtéren és elsősorban napsütéses időben ez határozza meg leginkább az egyének hőérzetét (Ali-Toudert and Mayer 2006, Gulyás et al. 2006). Különösen nagymértékü termikus stressz alakulhat ki például egy meleg nyári napon, ha erős direkt napsugárzásnak tesszük ki szervezetünket, vagy például egy szeles téli napon, miközben árnyékos területen tartózkodunk (Höppe 1999).

A probléma kiküszöbölésére olyan racionális modelleket és ezekből származtatható racionális bioklimatikus indexeket fejlesztettek ki, melyek már komplex módon figyelembe veszik az emberi test és környezete között kialakuló hőcserefolyamatokat és az emberi szervezet hőszabályozási mechanizmusait. E racionális indexek az összes olyan meteorológiai, illetve személyes tényezőt számításba veszik, melyek az ember és a környezete között lejátszódó termikus folyamatokban kulcsfontosságú szereppel bírnak. Így számolnak a léghőmérséklet, a légnedvesség, a szélsebesség, valamint a rövid- és hosszúhullámú sugárzási komponensek hatásával, továbbá a legfontosabb személyes jellemzőkkel, így a ruházat hőszigetelö képességével, az emberi aktivitás intenzitásával összefüggő hőtermeléssel, a magassággal, a súllyal, a korral és a nemmel. ${ }^{2}$

Az egyik legismertebb racionális bioklímaindex az ún. Fiziológiailag ekvivalens hőmérséklet (Physiologically Equivalent Temperature - PET) (Höppe 1999). Az indexet széles körben használják az alkalmazott klimatológia területén, köztük turisztikai célokra is. (A PET-indexet részletesen a 4.1.1. fejezetben mutatom be.) Az említett, Matzarakis (2006)-féle klímaindex-osztályozás szerint például a PET önmagában használható a turisztikai klímapotenciál számszerüsítésére. De Freitas et al. (2008), Moreno (2010b) és Lin et al. (2015) ugyanakkor a PET (és általában a bioklímaindexek) önmagában vett turisztikai célú alkalmazásával nem értenek egyet. Kiemelik részben, hogy a bioklímaindexek nem veszik figyelembe, hogy a turisták ténylegesen hogyan értékelik a termikus körülményeket. Másrészt hangsúlyozzák, hogy a komplex turisztikai értékelésekhez nem elegendö pusztán a termikus elemek hatásával számolni. A célterületen kialakuló közérzetre és elégedettségre ugyanis nemcsak a hőérzettel összefüggő termikus klímaadatok, hanem azok fizikai és esztétikai megnyilvánulásai is jelentős hatással lehetnek (de Freitas 2003, Mansfeld et al. 2007, de Freitas et al. 2008, Moreno and Amelung 2009, Moreno 2010b, Scott et al. 2012, Rutty 2014, Lin et al. 2015).

Utóbbi hátrányt igyekeznek kiküszöbölni az említett osztályozási rendszer harmadik csoportjába tartozó mutatók, az ún. kombinált (összetett) indexek. Napjaink legszélesebb körben elterjedt és legalkalmasabbnak tartott, turisztikai klimatikus célokra alkalmazható mérő-

\footnotetext{
${ }^{2}$ A ruházat hőszigetelésének mértékét ún. ruházati egységekben (clo-unit) adják meg. 1 clo $=0,155 \mathrm{~K} /\left(\mathrm{W} / \mathrm{m}^{2}\right)$ egy tipikus utcai vagy üzleti öltözet hőszigetelő képességének felel meg. A belső hőtermelés értékét vagy az egész, vagy egy egységnyi testfelületre vonatkozón adják meg (tehát mind $\mathrm{W}$, mind $\mathrm{W} / \mathrm{m}^{2}$ egység alkalmazható). Utóbbi átváltható az ún. metabolikus egységekre (met), ahol 1 met $=58 \mathrm{~W} / \mathrm{m}^{2}$ a nyugodtan, egy helyben ülö személy belső hőtermelése (Kántor 2012).
} 
számai e csoportba sorolhatók. A kombinált indexek mögött az az elvi alapfeltevés áll, hogy az emberek nem külön-külön az egyes klimatikus állapotjelzőkre, hanem azok együttes hatására reagálnak (Mieczkowski 1985, de Freitas 1990, 2003, Höppe 1993, Gössling et al. 2006, Lin et al. 2015). Ezek a különbözö paraméterek többféle módon is kifejthetik hatásukat az emberre: fiziológiailag, fizikailag és pszichológiailag (Gómez Martín 2005). A hatásuk jellege alapján de Freitas (2003) a turizmusra befolyással bíró fő klimatikus paramétereket három tényezőcsoportba sorolta: termikus, fizikai és esztétikai (2.1. táblázat).

A termikus tényezők közé tartozik a bioklimatikus indexek esetében említett valamennyi, hőcserefolyamatot és hőháztartást befolyásoló paraméter. E változók szabják meg a szervezetre ható termofiziológiai stressz mértékét, valamint alakítják ki az egyének hőérzetét és komfortérzetét. A fizikai tényezők mechanikai (fizikai) hatásukon keresztül közvetve vagy közvetlenül befolyásolják az egyének kényelmét és elégedettségét. Ide tartoznak például a különböző csapadékfajták vagy a szél fizikai hatása. Utóbbi kapcsán említhető kellemetlen körülmény például a tengerparton a személyes tárgyainkban esett kár (napernyő elrepülése) vagy a szemünkbe szálló homok. Az esztétikai jellegü tényezők a környezet vizuális észlelését, ezáltal vonzerejét és élvezeti értékét befolyásolják (pl. napfény, felhőzet, látástávolság). Például sokkal nagyobb élvezeti értékkel bír egy természeti vagy épített örökség szépsége derült vagy kissé felhős égboltviszonyok és jó látási körülmények között (2.1. táblázat).

2.1. táblázat: A turisztikai tevékenységeket befolyásoló fő éghajlati tényezők és jelentőségük (de Freitas 2003 után módosítva)

\begin{tabular}{|c|c|c|c|}
\hline $\begin{array}{l}\text { Tényezö- } \\
\text { csoport }\end{array}$ & Éghajlati tényezők & Jelentőség & Hatás jellege \\
\hline \multirow[t]{2}{*}{ Termikus } & $\begin{array}{c}\text { léghőmérséklet, } \\
\text { szélsebesség, } \\
\text { légnedvesség, }\end{array}$ & $\begin{array}{l}\text { fiziológiai stressz, } \\
\text { höérzet, } \\
\text { termikus komfort }\end{array}$ & \multirow[t]{2}{*}{$\begin{array}{l}\text { termofiziológiai/biológiai } \\
\text { (bioklimatológiai) }\end{array}$} \\
\hline & $\begin{array}{l}\text { legnedvesseg, } \\
\text { hőhatású (IR) sugárzás }\end{array}$ & klímaterápia & \\
\hline \multirow{6}{*}{ Fizikai } & UV-sugárzás & egészség, napozás, napégés & \multirow{2}{*}{$\begin{array}{l}\text { fiziológiai/biológiai } \\
\text { (bioklimatológiai) }\end{array}$} \\
\hline & levegőminőség & egészség, allergia, közérzet & \\
\hline & szél & por, homok, vagyoni kár & \multirow{4}{*}{ fizikai/mechanikai } \\
\hline & eső & $\begin{array}{c}\text { elázás, csökkent látási viszonyok } \\
\text { és élvezet }\end{array}$ & \\
\hline & hó & téli sportok, tevékenységek & \\
\hline & jegesedés & személyi sérülés, vagyoni károk & \\
\hline \multirow{3}{*}{ Esztétikai } & napfénytartam/felhöborítottság & terület vonzereje, élvezeti értéke, & \multirow{3}{*}{ pszichológiai/vizuális } \\
\hline & látási viszonyok, köd & vizuális komfort & \\
\hline & nappal hossza & $\begin{array}{l}\text { tevékenységek időtartama, } \\
\text { kellemessége }\end{array}$ & \\
\hline \multicolumn{2}{|c|}{ de Freitas (2003) szerint } & \multicolumn{2}{|c|}{ de Freitas (2003) után módosítva } \\
\hline
\end{tabular}

Finomítva a 2.2. ábrán látható összefüggéseket, a fenti három tényezőcsoport turizmusra gyakorolt hatása könnyebben megérthető (2.4. ábra). A vonzerő és a kockázat viszonyát Perry (1997) és de Freitas (2003) után Scott et al. (2012) gondolta tovább. Alapgondolata szerint az eredeti kétirányú, parabolikus összefüggés általában csak a termikus tényezőkre vonatkozik. Szélsőségektől mentes körülmények esetén termofiziológiai stressz nem jellemző, 
s a hőérzet és a komfortérzet is optimális. Szélsőséges éghajlati körülmények felé tartva viszont mindkét irányban növekszik a fiziológiai stressz mértéke, és a hőérzet és komfortérzet is szélsőséges irányba módosul. A fizikai és esztétikai tényezők esetében ugyanakkor inkább egy irányban történik a változás, vagyis egy adott küszöbérték felett a vonzerő eröteljesen lecsökken, míg a kellemetlen körülményeknek való kitettség kockázata folyamatosan emelkedik. Ha még tovább szeretnénk árnyalni a képet, azt lehet mondani, hogy az esztétikai tényezők esetében a vonzerő kevésbé hirtelen csökken, míg a kockázat nagysága ebben az esetben elenyésző. Például már akár egy gyenge csapadéktevékenység megindulása vagy a szélsebesség kisebb mértékü növekedése is gyorsan és eröteljesen csorbítani tudja a terület vonzerejét. Ugyanakkor például a napsütés átmeneti megszünése, a felhőzet megnövekedése csökkentheti ugyan a vonzerőt, de ennek korlátozó hatása általában kisebb, mint a fizikai tényezők esetében. A felhősödés által okozott tevékenységkorlátozás pedig a legtöbb esetben kevésbé jelentős az előbbiekhez képest (természetesen nem ide értve a napozást), kockázatot pedig lényegében nem rejt magában (Scott et al. 2012).

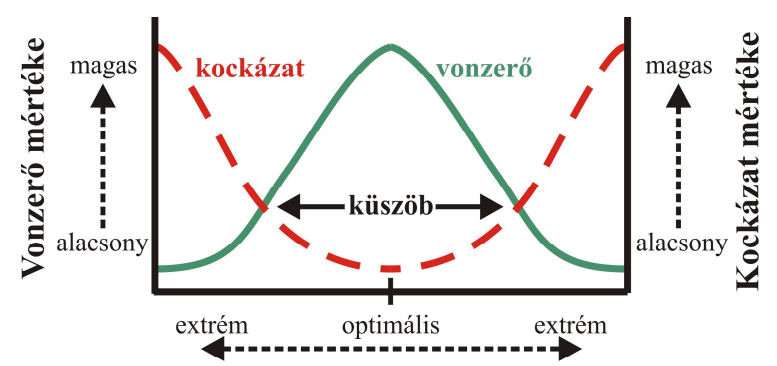

Klímatartomány (termikus tényező)

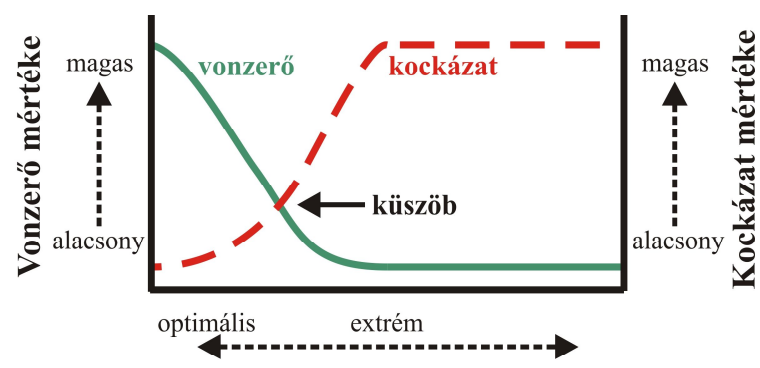

Klímatartomány (fizikai és esztétikai tényező)

2.4. ábra: Az éghajlat termikus, fizikai és esztétikai tényezőinek sematikus reprezentációja a turisztikai klímapotenciál alakulásában (Perry 1997, de Freitas 2003, Scott et al. 2012)

A turisztikai klimatológiában használható korszerü értékelő módszerekkel szemben támasztott elvárásokat de Freitas és munkatársai foglalták össze (de Freitas 2003, de Freitas et al. 2008). Véleményük szerint egy korszerü turisztikai klimatikus indexnek a légköri környezet termikus, fizikai és esztétikai megnyilvánulását is figyelembe kell venni. A termikus komponenseinek valamely humánenergiaegyenleg-alapú modellböl levezethető indexre kell támaszkodnia. Kívánatos továbbá, hogy az értékelő eszköz empirikusan tesztelve (validálva) legyen a lakosság vagy a turisták szubjektív véleményét alapul véve. Hangsúlyozzák, hogy a legmegfelelőbb validálási módszer maguknak a célszemélyeknek a megkérdezésén alapul (p1. „in-situ”, vagyis helyszíni kérdőívek útján). A gazdasági indikátorok, mint például a látogatószám, a férőhely-kapacitás kihasználtsága viszont kerülendők, mivel ezeket klimatikus okokon kívüli szempontok is befolyásolhatják.

A kérdő́ves felmérés útján végzett validáció központi eleme a termikus éghajlati tényezőkkel kapcsolatos értékelések, a termikus viszonyokra adott pillanatnyi reakciók feltérképezése. Ennek során általában vagy külön-külön az egyes paraméterekre (léghőmérséklet, légnedvesség, szélsebesség, napsugárzás) vonatkozó érzetet (a termikus alapparaméterek percepcióját), vagy a paraméterek összetett hatásaként kialakuló szubjektív hőérzetet vizsgálják. A szubjektív hőérzet kérdőíves felmérése nominális kategóriákkal ellátott speciális szemantikus differenciálskálákon történik. Leggyakrabban az Amerikai Épületgépész-mérnökök Egyesületének (American Society of Heating, Refrigerating and Air-Conditioning Engineers - ASHRAE) által kifejlesztett hétfokozatú skálát használják (ún. standard ASHRAE-skála, 
ASHRAE 2004). E skála hét fő hőérzeti kategóriát foglal magában, a hidegtől a meleg kategóriáig terjedve: hideg, hüvös, enyhén hüvös, neutrális, enyhén meleg, meleg és forró. A szakirodalomban kisebb számban három és öt fokbeosztású hőérzeti skálákra is találunk példát. A szabadtéri termikus komfort és a turisztikai klimatológiai tanulmányokban egyre nagyobb számban használják a kilenc fokbeosztású skálát, amelyben az eredeti ASHRAE-skála két ellentétes vége egy-egy extrém kategóriával ki van egészítve (nagyon hideg, nagyon forró).

A turisztikai klimatológia mindmáig egyik legvitatottabb kérdése, hogy a napjainkig kifejlesztett mérőszámok megfelelőek-e, egyáltalán megalkotható-e egy olyan, standard módszereken nyugvó index, amellyel korrekt módon számszerűsíthetők, s ezáltal összevethetők a különböző területek éghajlati viszonyai és azok turisztikai klímapotenciálja. Mivel a korszerü szakirodalom a kombinált indexeket tartja a legalkalmasabb méröszámoknak a turisztikai klímapotenciál jellemzésére, és öket alkalmazza legnagyobb számban, dolgozatom további részei a kombinált indexeken alapulnak. A következő fejezetben részletesen bemutatom a legfontosabb kombinált eszközöket.

\subsection{A turisztikai klíma értékelése}

\subsubsection{Turisztikai klíma index (TCI)}

A Mieczkowski (1985) által kifejlesztett Turisztikai klíma index (Tourism Climatic Index - TCI) nem új keletü, ugyanakkor napjainkban is széles körben alkalmazott összetett index, amely a klimatikus viszonyok általános szabadtéri turisztikai tevékenységekre (p1. városnézés, kikapcsolódás és egyéb könnyü fizikai tevékenységek) gyakorolt hatását számszerüsíti. A TCI az elmúlt évtizedek legszélesebb körben használt turisztikai klimatikus mutatója (Scott et al. 2012). Létrehozásakor egyik fó szempontként Mieczkowski azt tartotta, hogy olyan (időbeli felbontású) meteorológiai alapadatokra támaszkodjon, melyek szerte a világon egyszerüen mérhetők és könnyen hozzáférhetők, s így lehetőséget teremtenek a turisztikai klímapotenciál egységes értékelésére és összehasonlítására.

$\mathrm{Az}$ index hét, a turizmus számára releváns meteorológiai paraméter havi értékeire épül. A hét alapparamétert öt al-indexbe integrálja (2.2. táblázat). Az alapparaméterek közül hármat (csapadék, napfénytartam, szélsebesség) önmagában értékel különböző pontértékekkel, míg a léghőmérséklet és a légnedvesség mutatókat egymással kombinált formában veszi figyelembe (ún. nappali és napi komfortindex formájában). A három önálló paramétert egy 0 (kedvezőtlen) és +5 (optimális) között futó skálán, míg a termikus komfortviszonyokat kifejező kombinált tényezőket -3 és +5 közötti pontrendszer szerint értékeli (2.2. táblázat, 2.5-6. ábra).

Az öt al-indexet végül - relatív fontosságuk alapján - különböző súlyokkal veszi figyelembe az index végső értékének kiszámításához:

$$
\mathrm{TCI}=2 \times(4 \times C I d+C I a+2 \times R+2 \times S+W) .
$$

A termikus komfortviszonyokat két al-index, a nappali komfortindex $(C I d)$ és a napi komfortindex (CIa) jellemzi. A szerző meglátása szerint legnagyobb fontossággal (súllyal) a CId tag bír, mivel ez a tényező a nap legnagyobb turisztikai forgalommal jellemezhető időszakában (kora délután) uralkodó termikus viszonyokra vonatkozik. Ennek megfelelöen ez az al-index a napi maximum-hőmérsékleten és minimum relatív nedvességen alapul. A CIa tag 
jóval kisebb súlyát pedig azzal indokolja a szerző, hogy ez a tag egész napra vonatkozó információtartalmat hordoz magában, tehát figyelembe veszi az éjszakai időszakot is, amikor csekély számú turista tartózkodik szabadtéri környezetben. Ez az al-index a napi átlaghőmérsékleten és átlagos relatív nedvességen alapul (2.2. táblázat).

2.2. táblázat: A Turisztikai klíma indexet (TCI) felépítő al-indexek és az ezeket alkotó alapparaméterek, értéktartományuk, turisztikai jelentőségük, valamint súlyozásuk (Mieczkowski 1985 után módosítva)

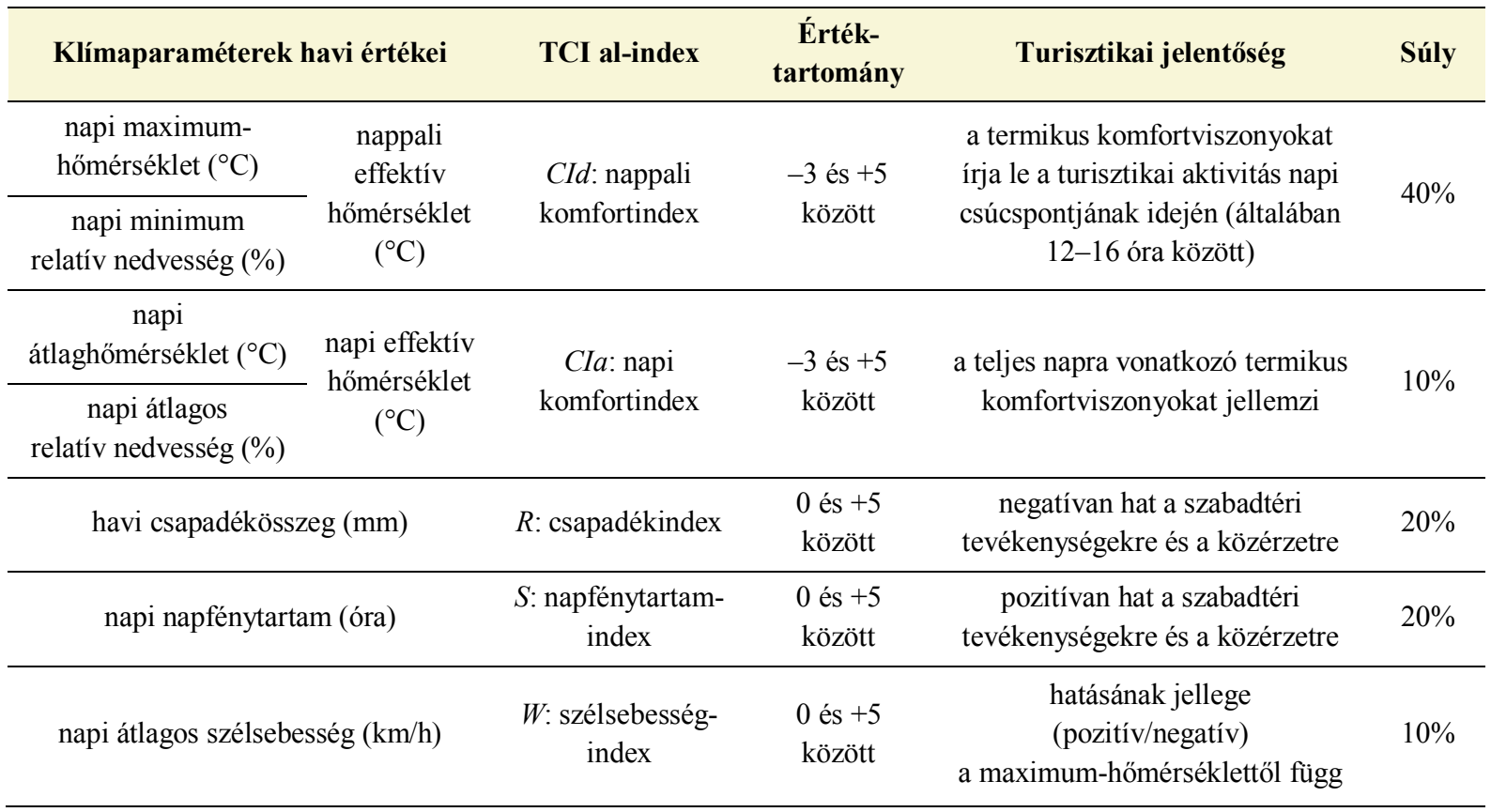
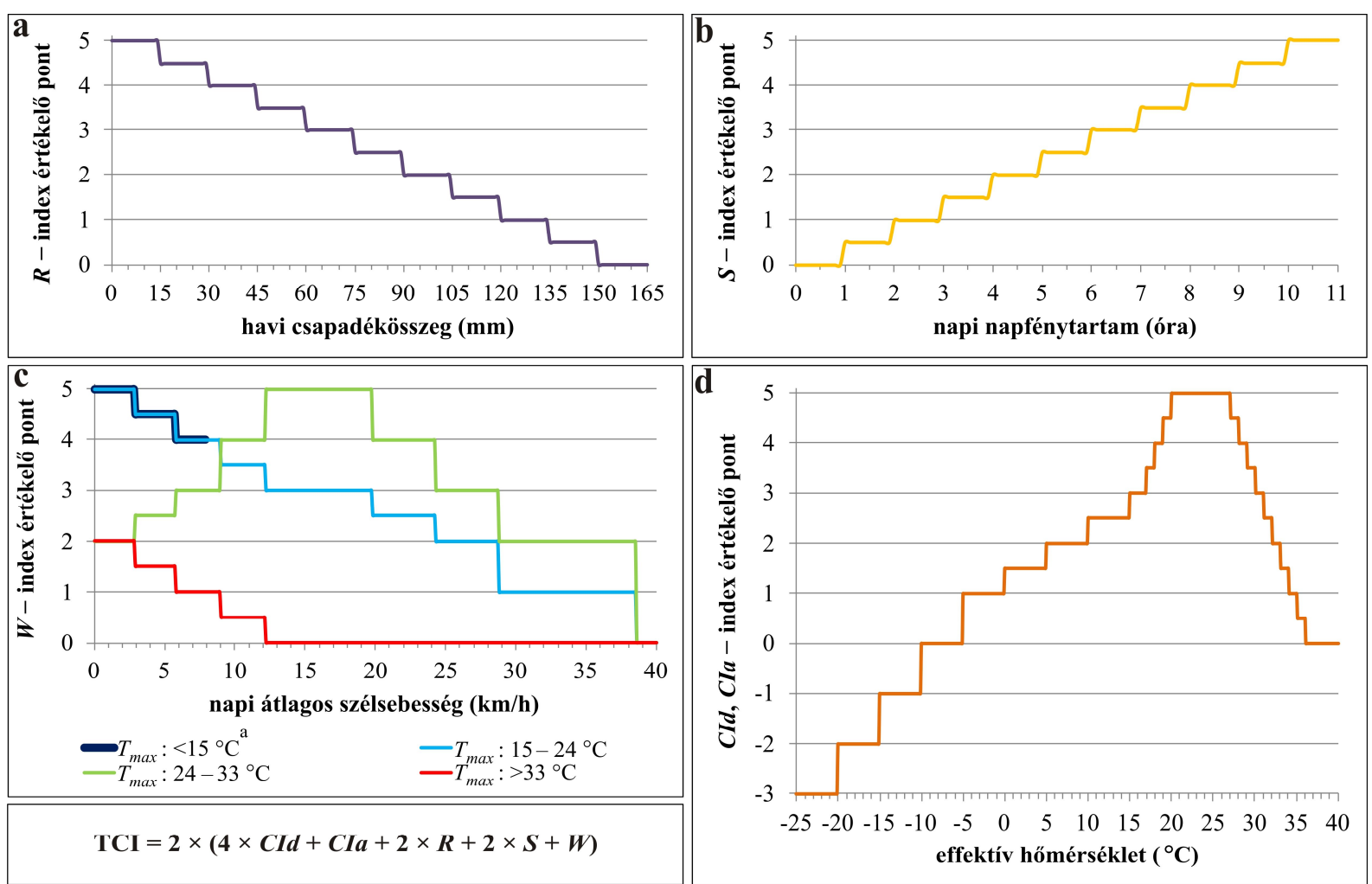

a $8 \mathrm{~km} / \mathrm{h}$-nál nagyobb szélsebesség esetén a „wind chill” nomogram használatos (Függelék 1. ábra)

2.5. ábra: A Turisztikai klíma index (TCI) egyes al-indexeinek értéktartományai (szerkesztette Kántor N., Kovács et al. 2017) 
A nappali és a napi komfortindex értékelő pontrendszere valójában az egyik legkorábbi, egyszerü empirikus termikus indexen, az ún. effektív hőmérséklet (Effective Temperature ET) értékén alapul, amely a léghőmérséklet, valamint a relatív nedvesség termikus komfortra gyakorolt együttes hatását fejezi ki (2.2. táblázat). Az indexet eredetileg Houghten and Yaglou (1923) fejlesztette ki. Kidolgozása során nagyszámú tesztalanyt vetettek vizsgálat alá, akik ún. klímakamrákban tartózkodtak. Ennek során az alanyok különböző léghőmérsékletlégnedvesség kombinációk által kiváltott pillanatnyi szubjektív hőérzetét vizsgálták, s az így nyert azonos hőérzetü görbék adták az effektív hömérséklet izovonalait. Az eredményeket ún. pszichrometrikus grafikonon ábrázolták, amelyen a léghőmérséklet, a légnedvesség és az effektív hömérséklet görbéit tüntették fel (pl. 2.6. ábra). Gyakran meghatározták az ún. optimális komforttartományt, amelynél az alanyok a legnagyobb arányban jellemezték kellemesnek hőérzetüket (a termikus viszonyokkal elégedettek aránya a legnagyobb volt). Természetesen e tartományban nem érzi mindenki kellemesen magát, de mindazok aránya, akik túl melegnek, vagy túl hüvösnek tartják a környezetet csupán 5-20\% között változik (Mieczkowski 1985).

A következő legalább negyven év során - általában egy korábbi vizsgálatra épülve, esetenként annak metodológiáját megcáfolva - számos új pszichrometrikus ábrát (effektív hőmérséklet grafikont) alkottak meg (pl. Rohles and Nevins 1968, 1973, Gagge et al. 1971). (A témával kapcsolatban részletes történeti áttekintés található például Volmer 1975, Aynsley and Szokolai 1998, Fountain et al. 1999 és Auliciems and Szokolay 2007 munkáiban). Fontos kiemelni, hogy a klímakamra-kísérletek eredményei az ASHRAE koordinálásával a beltéri termikus környezet értékelésére készültek, s a fütés- és hütéstechnikai ipart szolgálták ki eredményeikkel (az alanyok zárt térben ültek, illetve könnyü irodai munkát végeztek). Az aktuális eredményeket tucatnyi ASHRAE-szabványban tették közzé.

A TCI termikus komponenseinek értékelésére Mieczkowski az 1972-es effektív hőmérsékleti grafikont (ASHRAE 1974) vette alapul. Ugyanakkor kiemelte, hogy mivel azt beltéri környezetre fejlesztették ki, kisebb módosítást hajtott végre a görbék elrendezésében, hogy az a kültéri körülményekre minél relevánsabb legyen (2.6. ábra). (A módosítás hátterében álló elméleti meglátásait felsorolja munkájában a szerző, arra viszont nem világít rá sem ő, sem az általam vizsgált későbbi munkák, hogy a gyakorlatban mit változtatott.) Az effektív hőmérsékleti görbék elrendeződése világosan mutatja, hogy adott léghőmérsékleti érték mellett a komfortérzet jelentősen változik a relatív nedvesség értékének módosulásával, $\mathrm{s}$ az is kitünik, hogy - az akkori kutatási eredményekkel összhangban - magasabb hőmérsékleten nagyobb jelentőséggel bír a páratartalom változása, mint alacsony hőmérsékleten (az effektív hőmérséklet görbéinek meredeksége a melegebb körülmények felé haladva csökken) (2.6. ábra).

Mieczkowski a 2.6. ábrán bemutatott pszichrometrikus grafikonra alapozta a CId és a CIa tagok értékelését, és hangsúlyozta, hogy az ASHRAE (1974)-féle optimális komforttartományt, amelyet $20-27^{\circ} \mathrm{C}$ közötti effektív hőmérséklet tartományként azonosít, vette az értékelés szempontjából is optimálisnak, s így a maximális 5,0 értékelő pontot rendelte hozzá (2.5.d., 2.6. ábra). A többi értékelő pont közötti határokat a 2.6. ábrán látható effektív hőmérsékleti görbék alkották úgy, hogy az optimális tartománytól haladva mindkét irányban folyamatosan csökken az adható pontérték a szélsőséges viszonyok növekedésével (2.5.d., 2.6. ábra). Látható, hogy az értékelő pontrendszer -3-as értékig tart. A kiosztott pontokból az is tükröződik, hogy az alanyok melegebb termikus viszonyok esetén a léghőmérséklet és a relatív nedvesség kombinációjaként kialakított effektív hőmérséklet egységnyi változására intenzívebb negatív reakciót adnak, míg a hüvös oldalon „toleránsabbnak” mutatkoznak. 


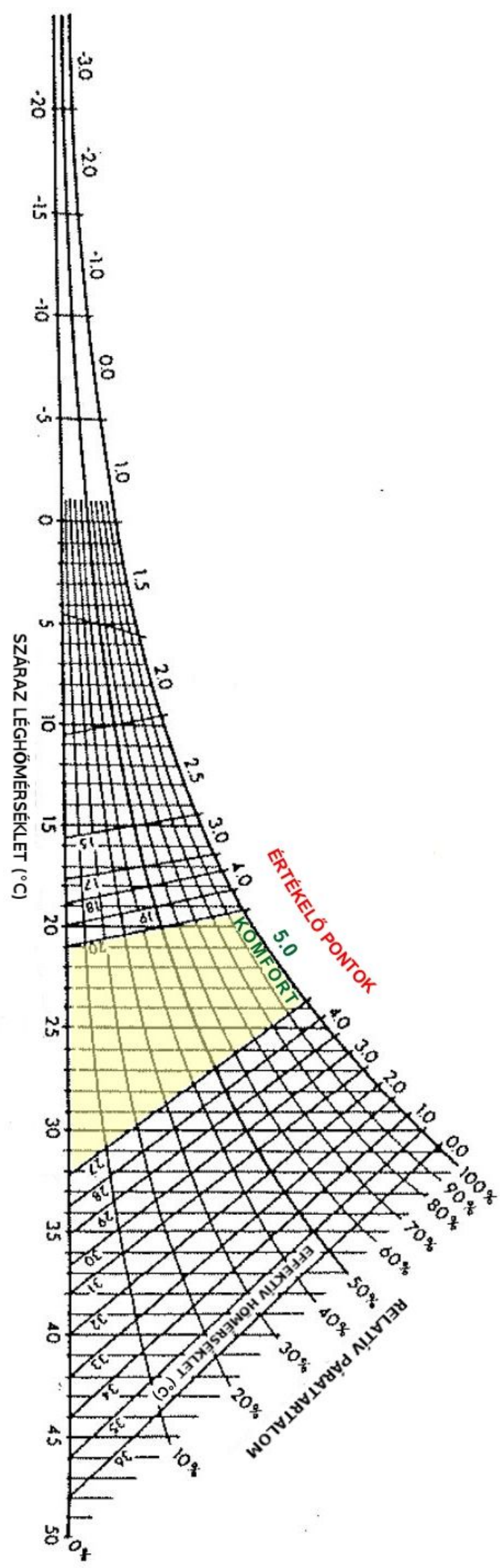

2.6. ábra: ASHRAE (1974) után Mieczkowski (1985) által módosított effektív hőmérsékletek grafikonja a Turisztikai klíma index (TCI) termikus tagjaihoz tartozó értékelő pontokkal (Mieczkowski 1985 alapján) 
A TCI részét képezi a havi csapadékösszegen alapuló al-index $(R)$, amely mennyiséget szintén olyan megfontolásból választott ki a szerző, hogy világszerte könnyen hozzáférhető legyen, ugyanakkor megjegyzi, hogy az abszolút csapadékértéken kívül annak időbeli eloszlása is rendkívül sokat számít a turisztikai tevékenységek szempontjából (a hónap során ritkán előforduló, rövid ideig tartó záporeső vagy hosszabb időszakokban fennálló egyenletes csapadék). A csapadék értékelő rendszere szerint az egyre növekvő mennyiség egyre kevésbé kedvező: az értékelésben a legmagasabb pontszámot $(5,0)$ a havi 15 mm-nél kevesebb csapadék kapja, és minden további $15 \mathrm{~mm}$ esetén 0,5 ponttal csökken az adható pontérték (2.5.a. ábra).

$\mathrm{Az}$ index tartalmazza a napi napfénytartam havi átlagát kifejező al-indexet $(S)$ is, amelynél kitér annak pozitív (napfürdőzés, vizuális élvezet) és negatív (egészségügyi problémák, valamint a sugárzás humánkomfortot károsan befolyásoló szerepe a test felé irányuló sugárzásos hőszállítás miatt) hatásaira is. Végeredményben a napfénytartamot pozitív mennyiségként kezeli, és a legjobb értékelést a legalább 10 óra/nap havi átlag feletti területek (időszakok) kapják. A napfénytartam csökkenésével a kiosztott pontértékek is csökkennek (2.5.b. ábra).

Az utolsó, ám egyik legkomplikáltabb tagja a TCI-nak a szélsebesség al-index $(W)$, amelynek értékelését megnehezíti, hogy rendkívül változó és változatos komfortérzetet eredményez, attól függően, hogy az adott régió milyen klimatikus övezetben helyezkedik el és milyen idöszakról (hónap, évszak) beszélünk. Mieczkowski ekképpen a léghőmérséklettől (az adott havi átlagos maximum-hőmérséklettől) függően állította fel értékelő pontrendszereit, és összesen négy fö csoportot határozott meg (2.5.c. ábra):

1. Az ún. normál rendszer területein, ahol az átlagos napi maximum-hőmérséklet 15-24 ${ }^{\circ} \mathrm{C}$ között alakul, a legalacsonyabb szélsebesség a legkomfortosabb, és 5 pontot kap. Ilyen hőmérsékleti tartomány esetén a szélsebesség növekedése fokozódó, nemkívánatos konvektív hőveszteséget, s így hideg általi diszkomfortot okoz. Így a szélsebesség növekedésével csökken az értékelésben adandó pontszám.

2. Az ún. passzát szélrendszer területein, ahol az átlagos napi maximum-hőmérséklet 24-33 ${ }^{\circ} \mathrm{C}$ fok között alakul, a szélsebesség fokozódása egy ideig kívánatos, hiszen segíti a szervezet konvektív és evaporatív hőleadását, amire a magasabb léghőmérsékleti viszonyok miatt a szervezetnek szüksége van. Így ezeken a területeken (időszakokban) nem a legkisebb, hanem a $12-20 \mathrm{~km} / \mathrm{h}$ közötti szélsebesség nyújtja a legkomfortosabb körülményeket (5 pont). Ennél kisebb szélsebesség esetén kevésbé érvényesül a konvektív és evaporatív hőleadást elősegítő hatás, míg nagyobb szélsebesség esetén már a kellemetlen mechanikai hatás válik egyre eröteljesebbé, ami lecsökkenti a pontértéket.

3. A forró klímájú területeken, ahol az átlagos napi maximum-hőmérséklet meghaladja a $33{ }^{\circ} \mathrm{C}$-ot, a konvektív hőelvonás általi hütőhatás már nem érvényesül, a legkisebb szél is diszkomfortérzetet vált ki, mivel meleg levegőt, többlet hőt szállít a test felé. Ez a konvektív úton szállított érzékelhető hőbevétel rendkívül megterhelő a szervezet számára, különösen ebben a már eleve meleg levegőben. Így a szélsebesség értékelése itt 5,0 helyett csak 2,0 értékig terjed, és $12 \mathrm{~km} / \mathrm{h}$ felett már 0 értékkel jellemezhető.

4. A hideg hónapokban, amikor az átlagos napi maximum-hőmérséklet nem éri el a 15 ${ }^{\circ} \mathrm{C}$-ot és ez nagyobb mint $8 \mathrm{~km} / \mathrm{h}$ szélsebességgel társul, az Environment Canada (kanadai meteorológiai szolgálat) által - korábbi kutatásokra épülve - kifejlesztett ,wind chill” nomogram képezi az értékelés alapját (Függelék 1. ábra). Ennek magyarázata, hogy ilyen körülmények között a normál osztályozáshoz hasonlóan a fokozódó szélsebesség egyre nagyobb konvektív hővesztést, és így hideg általi diszkomfortot okoz, 
ami az alacsony hőmérséklet és a nagy szélsebesség mellett kellemetlen, akár veszélyes mértékü is lehet. Amennyiben a szélsebesség $8 \mathrm{~km} / \mathrm{h}$ alatt marad a $15{ }^{\circ} \mathrm{C}$-nál alacsonyabb hőmérséklettel párhuzamosan, a normál szélrendszerek értékelése használható.

A TCI-értékek osztályozása egy előre definiált, -20 -tól +100-ig terjedő skálán történik (2.3. táblázat). A magasabb TCI-értékek kedvezőbb klimatikus viszonyokat jeleznek a szabadtéri turisztikai tevékenységek számára (Mieczkowski 1985).

2.3. táblázat: A Turisztikai klíma index (TCI) értékének osztályozása (Mieczkowski 1985)

\begin{tabular}{cc}
\hline TCI-érték & Leíró kategóriák \\
\hline $90-100$ & ideális \\
\hline $80-89$ & kitünő \\
\hline $70-79$ & nagyon jó \\
\hline $60-69$ & jó \\
\hline $50-59$ & elfogadható \\
\hline $40-49$ & semleges \\
\hline $30-39$ & kedvezőtlen \\
\hline $20-29$ & nagyon kedvezőtlen \\
\hline $10-19$ & rendkívül kedvezőtlen \\
\hline$-20-9$ & alkalmatlan \\
\hline
\end{tabular}

Scott and McBoyle (2001) a TCI értékének évi eloszlása alapján hat eltérő típust definiált úgy, hogy elméletileg minden helyszín TCI-menete megfelel az egyik kategória jellemzőinek (2.7. ábra). Ezáltal szemléletesen el lehet különíteni, hogy az év mely időszakai kedvezőek vagy éppen alkalmatlanok városi turizmus tekintetében.

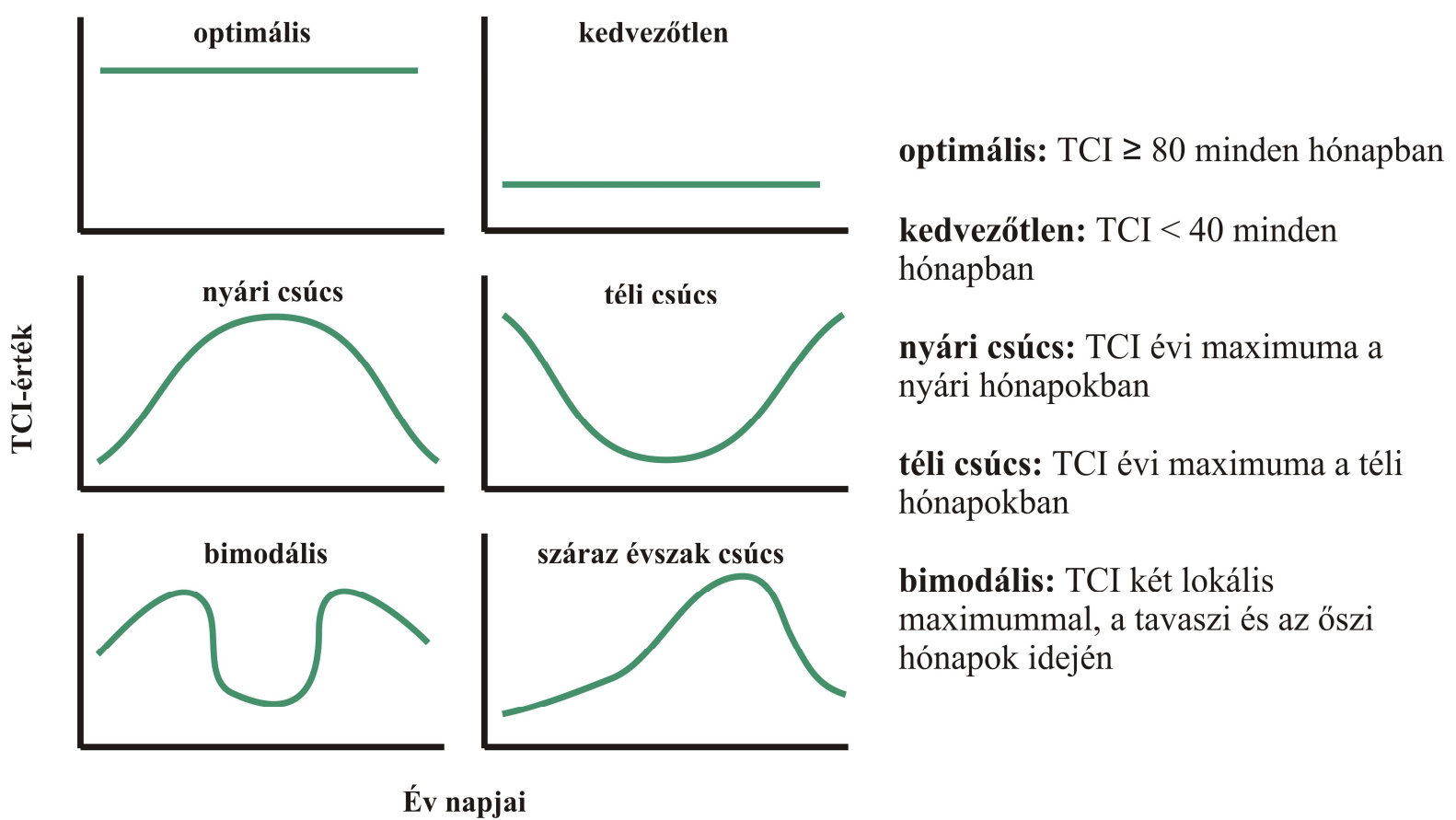

2.7. ábra: A Turisztikai klíma index (TCI) évi eloszlásának hat elméleti alapesete és definícióik (Scott and McBoyle 2001) 
A TCI-t széles körben alkalmazzák különböző turisztikai célterületek klímapotenciáljának jellemzésére és összehasonlítására. Gyakran használt a klímaváltozás turizmusra gyakorolt globális vagy regionális hatásának számszerüsítésére is, amely során különböző éghajlati szcenáriókkal végzett klímamodell-kísérletek eredményeit használják fel az index számításához. A jelenlegi klímapotenciál alakulását vizsgálta a TCI alapján Roshan et al. (2009) Teherán (Irán) városára, Farajzadeh and Matzarakis (2009) Irán északnyugati részére, míg Roshan et al. (2016a) Irán egész területére vonatkozóan. Klímamodelladatok alapján jövőbeli időszakokra is vizsgálta a TCI tér- és időbeli alakulását Whittlesea and Amelung (2010) Anglia délnyugati részére és Nicholls and Amelung (2008) Északnyugat-Európa területére. Kontinens léptékű skálán végzett vizsgálatot Amelung and Nicholls (2014) Ausztráliára, Scott and McBoyle (2001) és Scott et al. (2004) Észak-Amerika, Amelung and Viner (2006), Hein et al. (2009), Perch-Nielsen et al. (2010), valamint Amelung and Moreno (2012) pedig Európa területére. Amelung et al. (2007) globális szinten, az egész világra kiterjedően végzett TCI-alapú vizsgálatokat.

\subsubsection{Második generációs turisztikai klíma index (CIT)}

A második generációs turisztikai klíma index (Climate Index for Tourism - CIT) az időjárási és éghajlati körülményekkel kapcsolatos elégedettség mértékét adja meg egy 7 fokozatú skálán (de Freitas et al. 2008). A skála legalacsonyabb értékei (1-3) „kedvezőtlen”, köztes értékei (4-5) „elfogadható”, míg legmagasabb értékei (6-7) ,ideális” klimatológiai viszonyokat jelentenek turisztikai szempontból (2.4. táblázat). A CIT előnye, hogy a kimeneti értékét a turisztikai klíma termikus $(T)$, esztétikai $(A)$ és fizikai $(P)$ tényezőcsoportja együttesen határozza meg. Az index az egyes éghajlati változók hatását nem a tagok összegeként vagy bármilyen lineáris függvénykapcsolataként, hanem azok speciális, gyakorlatorientált kombinációjaként veszi figyelembe. Ez azt jelenti, hogy bizonyos - szakirodalmi megfontolások szerint vett (de Freitas 1985, 1990) - küszöbértékek felett a fizikai tagok (csapadék, szélsebesség) felülírják a termikus és esztétikai tényezők hatását (ún. „overriding effect” - felülíró hatás) (de Freitas 1990, de Freitas et al. 2008). Egy hétköznapi példával élve: a turista egy tengerparton hiába ítéli kellemesnek a termikus viszonyokat és a tiszta égboltviszonyok miatt vizuálisan szépnek a tájképet, ha a szél mechanikai ereje közvetlenül (személyes tulajdonban esett kár) vagy közvetve (homokvihar) elégedetlenséget szül. A három tényezőcsoport közötti összefüggést a következő általános megközelítés alapján lehet leírni:

$$
\mathrm{CIT}=f[(T, A)] \times P
$$

amiből megnyilvánul a fizikai $(P)$ tényezőcsoportnak a termikus $(T)$ és esztétikait $(A)$ felülbíráló hatása.

A CIT további előnye, hogy a kimeneti értéke kérdőíves felmérés alapján egyszerüen validálható. A CIT eredendően a tengerparti turizmussal kapcsolatos éghajlati értékelésre került kidolgozásra és egyúttal validálásra. Ennek során 331 waterlooi (Kanada) egyetemi hallgatót kérdeztek meg ,ex-situ” módon (tanteremben), hogy különböző $T-A-P$ kombinációk esetében értékeljék az éghajlattal való elégedettségüket a már említett 1-től 7-ig tartó skálán, miközben tengerparti látogatást feltételeznek. Az eredmények ún. időjárás-tipológiai mátrixban kerültek összesítésre (2.4. táblázat, de Freitas et al. 2008). A termikus (hőérzetre vonatkozó) érté- 
kelés az ASHRAE - eredetileg 7 fokozatú, hidegtől forróig terjedő - hőérzeti skálájának 9 fokozatúvá bővített változatán alapul. Mindegyik hőérzeti kategóriára vonatkozóan a feltételezett esztétikai körülményt (felhőborítottság mennyisége), illetve bizonyos küszöbhatárok felett a fizikai tényezők (csapadékmennyiség, szélsebesség) befolyásoló szerepét kellett értékelniük 1-től 7-ig, ahol 1 jelenti a kedvezőtlen, míg 7 az ideális körülményeket.

2.4. táblázat: CIT-értékelés a tengerparti turizmusra vonatkozóan a turisztikai klíma termikus $(T)$, esztétikai $(A)$ és fizikai $(P)$ tényezőin alapulva $(N=331)$ (de Freitas et al. 2008 alapján)

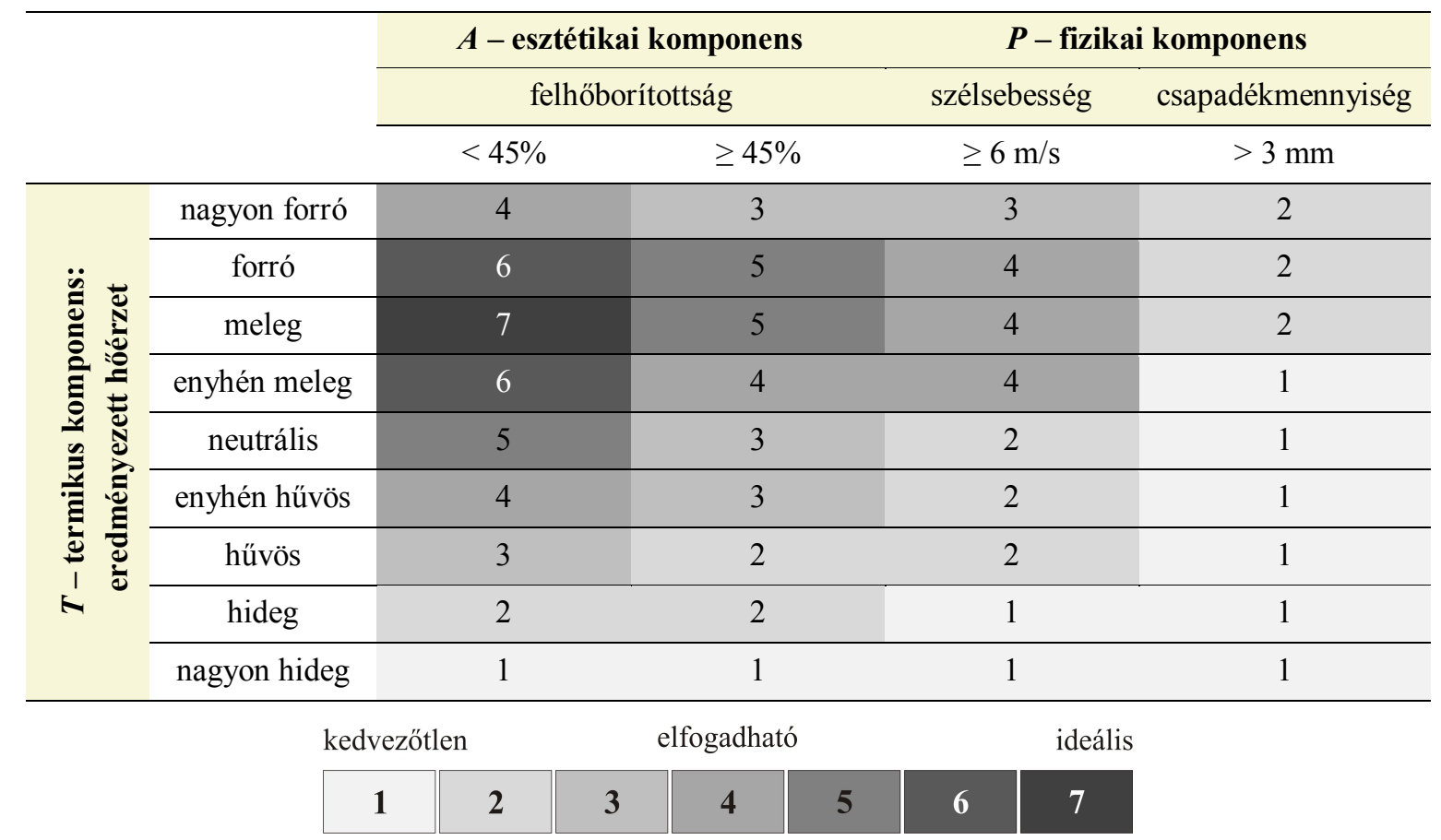

A szakmai gyakorlatban a CIT segítségével történő értékelés a következő lépések szerint történik. A termikus tag valamely komfortindex (pl. PET) általában napi átlagán alapul, amelyet átkonvertálhatunk a megfelelő hőérzeti kategóriára. Ezután megállapítjuk, hogy a napi felhőborítottság-adatunk a küszöbérték alatt vagy felett helyezkedik-e el, majd pedig hozzárendeljük a megfelelő hőérzethez tartozó mátrixbeli pontot. Végül megnézzük, hogy a napi csapadékösszeg- és a napi átlagos szélsebességértékünk az adott küszöbérték felett helyezkedik-e el, azaz befolyásolja-e a pontértéket (a 2.4. táblázatban látható tengerpartra vonatkozó tipológiai mátrix szerint általában „rontja-e”). Végeredményben megkapunk egy egyetlen (1 és 7 közötti) számértéket, amely együttesen számításba veszi a termikus, fizikai és esztétikai paraméterek hatását.

Egy példával élve, tegyük fel, hogy egy tengerparton eltöltött nap után kíváncsiak vagyunk a CIT értékére. Tételezzük fel, hogy a termikus alapparaméterek eredőjeként a PET napi átlagára $37{ }^{\circ} \mathrm{C}$-ot kapunk. Ez forró hőérzetnek felel meg (Matzarakis and Mayer 1996), így a táblázatnak ezt a sorát kell tekinteni. Ezután megvizsgáljuk a felhőborítottság-adatainkat, s azt találjuk, hogy napi átlagban az égbolt erősen felhős volt, így a maximálisan adható 6-os érték 5-re csökken. A napi átlagos szélsebességünk nem érte el a $6 \mathrm{~m} / \mathrm{s}$-ot, így az 5-ös értékünk nem csökken. Végül megnézzük a napi csapadékösszeg értékét: $1 \mathrm{~mm}$ esett, így az 5-ös értékünk továbbra is megmarad. Végeredményben tehát a CIT értékére ezen a napon 5 adódott, vagyis az elfogadhatónál némileg kedvezőbbként jellemezhetők az éghajlati körülmények (2.4. táblázat). 
Már maga de Freitas et. al (2008) is hangsúlyozta, hogy eredménye csak korlátozottan alkalmazható, mivel kisszámú mintán alapul, illetve csak a kanadai fiatal korosztályt és a tengerparti tevékenységet célozza meg. Szükségesnek tartja elkészíteni a mátrixokat nagyobb mintaszámra, többféle turisztikai tevékenységet, korosztályt és nemzetet is lefedve. Ennek megfelelően Bafaluy et al. (2014) új időjárás-tipológiai mátrixokat hozott létre számos szabadtéri turisztikai tevékenységre (kulturális/városlátogató turizmus, kerékpározás, labdarúgás, golf, vitorlázás, tengeri kishajózás, valamint a túrázás). Kutatásaikat Mallorcán végezték. Hangsúlyozzák ugyanakkor, hogy az új időjárás-tipológiai mátrixaik szakértőkkel és a tevékenységeket űző személyekkel folytatott konzultációkon alapulnak, s a jövőben mindenképp szükséges verifikálásuk kérdőíves úton. Jelenleg is folyik mind az eredeti, mind az újabb időjárás-tipológiai mátrixok verifikációja, esetleg kalibrálása (de Freitas 2015). Mindazonáltal az eddig kialakított mátrixok jelenleg a legelfogadottabbak a CIT-t használó turisztikai klimatológiai vizsgálatokban, és egyre szélesebb körben hódítanak teret (Amengual et al. 2012, Németh 2015, Zaninovic et al. 2015).

\subsubsection{Klíma-Turizmus-Információs-Rendszer (CTIS)}

Egy másik gyakran alkalmazott és úgyszintén újabb értékelö eszköz a Matzarakis (2007) által kifejlesztett Klíma-Turizmus-Információs-Rendszer (Climate-Tourism-InformationScheme - CTIS). Ez a módszer a TCI-al és a CIT-val ellentétben nem csupán egyetlen számszerü értékkel osztályozza az adott terület turisztikai klímapotenciálját, hanem egy komplex, színkódolt táblázatot ad eredményül. A táblázat különböző, turizmus szempontjából releváns időjárási vagy klimatikus körülmények gyakorisági eloszlását illusztrálja könnyen értelmezhető, szemléletes formában (Matzarakis 2007, 2014, Lin and Matzarakis 2008, Zaninovic and Matzarakis 2009). A relatív gyakoriságokat általában havi vagy tíznapos időszakra számolják ki (2.8. ábra).

A CTIS alapgondolata a CIT-hoz hasonlóan azon alapul, hogy figyelembe vegye a termikus, a fizikai, illetve az esztétikai tényezőcsoportba tartozó paramétereket (2.5. táblázat). A CTIS termikus komponensei $(T)$ nagyrészt a PET-indexre épülnek, de a légnedvesség hatását önmagában is tartalmazzák, amelyet a vízgőznyomás (e) gyakoriságán keresztül vesz figyelembe. A CTIS-ben szereplö esztétikai komponensek gyakoriságai a relatív nedvesség $(R H)$, valamint a felhőborítottság $(n)$ alapján kerülnek meghatározásra, míg a fizikai tényezők kategóriáján belül a csapadékmennyiség $(p)$ és a szélsebesség $(v)$, vagy éppen a hótakaró vastagságát (h) leíró mérőszámok a mérvadók (Matzarakis 2007, Matzarakis et al. 2010c, Matzarakis 2014).

A felsorolt paraméterekhez a szakirodalom alapján kijelölhető egy-egy küszöbérték, melyekkel olyan időjárási helyzeteket definiálhatunk, mint például a turisztikai tevékenységek szempontjából komfortos termikus környezet, a napsütéses, ködös vagy szeles időszakok, vagy éppen a síelésre alkalmas körülmények. Ugyanazon paraméterhez több küszöbérték is rendelhető, s így kedvező és kedvezőtlen időszakokat is megadhatunk segítségükkel. Például a termikus szempontból komfortos és a hideg- vagy hőstressz időszakait is a PET index értékei alapján definiáljuk, s a csapadékösszeghez rendelt küszöbértékeknek megfelelően vizsgálhatjuk a száraz és nedves napok gyakoriságát is (2.5. táblázat, 2.8. ábra). 
2.5. táblázat: A CTIS által vizsgált éghajlati körülmények a javasolt küszöbértékeikkel és a szakirodalmi hivatkozásaikkal (Matzarakis 2007, 2014, Matzarakis et al. 2010c)

\begin{tabular}{|c|c|c|c|}
\hline Tényezőcsoport & $\begin{array}{c}\text { Vizsgált klimatológiai } \\
\text { körülmény }\end{array}$ & Meghatározás & Szakirodalmi alap \\
\hline \multirow{4}{*}{ Termikus } & termikus komfort & $18^{\circ} \mathrm{C}<\mathrm{PET}<29^{\circ} \mathrm{C}$ & Matzarakis (2007) \\
\hline & hidegstressz & $\mathrm{PET}<0{ }^{\circ} \mathrm{C}$ & Matzarakis (2007) \\
\hline & hőstressz & $\mathrm{PET}>35^{\circ} \mathrm{C}$ & Matzarakis and Mayer (1996) \\
\hline & fülledtség & $e>18 \mathrm{hPa}$ & Scharlau (1943) \\
\hline \multirow{2}{*}{ Esztétikai } & napsütés & $n<5 / 8$ & Gómez Martín (2004) \\
\hline & köd & $R H>93 \%$ & Matzarakis (2007) \\
\hline \multirow{4}{*}{ Fizikai } & száraz nap & $p<1 \mathrm{~mm}$ & Matzarakis (2007) \\
\hline & nedves nap & $p>5 \mathrm{~mm}$ & Matzarakis (2007) \\
\hline & szeles idő & $v>8 \mathrm{~m} / \mathrm{s}$ & $\begin{array}{l}\text { Besancenot (1990), } \\
\text { Gómez Martín (2004) }\end{array}$ \\
\hline & sípotenciál & $h>10 \mathrm{~cm}$ vagy $30 \mathrm{~cm}$ & OECD (2007) \\
\hline
\end{tabular}

$\overline{\mathrm{PET}}=$ fiziológiailag ekvivalens hőmérséklet, $e=$ vízgőznyomás, $n=$ felhőzet mennyisége, $R H=$ relatív nedvesség, $p=$ csapadékösszeg, $v=$ szélsebesség, $h=$ hótakaró vastagsága

A gyakorisági táblázatok elkészitése egy egyszerü, felhasználóbarát (ugyancsak CTIS elnevezésü) szoftver segítségével történik, amely nemcsak klímaadatok, hanem bármilyen adatsor gyakorisági eloszlásának reprezentációjára alkalmas (Matzarakis 2007, Matzarakis et al. 2010c). A szoftverben a már elöre kiszámolt relatív gyakoriságokat (0-1 érték vagy 0-100\% között) kell betáplálni. Be lehet állítani, hogy az adatsor időbeli felbontása illeszkedjen annak későbbi megjelenítéséhez (pl. hónapok, tíznapos időszakok - dekádok, órák). A szoftver egyik kulcsfontosságú része a színösszeállítás beállítása, amit a gyakorisági értékektől tesz függővé. Definiálhatunk tetszőleges küszöbértékeket, amelyek közötti tartományokat elláthatunk egy-egy diszkrét színnel, de interpolálhatók is a színek folytonosan a küszöbértékek között (2.8. ábra).

A százalékos gyakoriság megjelenítésének az értelmezése gyakran nehézkes lehet, mert bizonyos meteorológiai körülmények (pl. csapadék, hőstressz) esetében a $0 \%$ gyakoriság az ideális szabadtéri turisztikai célokra, bizonyos változók esetében viszont a 100\% (utóbbira példa a termikus stresszmentes állapot, a napfényes időszak vagy a száraz napok mennyisége) (2.8. ábra). Ennek kiküszöbölésére a százalékos megjelenítés helyett vagy mellett gyakran használják a CIT-val ekvivalens kategorizálást, vagyis a kedvezőtlentől az ideálisig tartó hét kategóriát, ahol mindegyik színkód ugyanolyan széles (14\%-nyi) gyakorisági tartományt fed le. Mivel lehetőség van a színezés inverzzé konvertálására a szükséges adatsorok esetében, biztosítható, hogy az adott színnel ellátott kategória ugyanúgy értelmezhetö lehessen minden éghajlati körülmény szemszögéből (pl. turisztikai célokra általában a kis százalékban előforduló nedves nap és a nagy százalékban jelentkező száraz nap az ideális, ami ugyanolyan színnel és kategória elnevezéssel - pl. ideális - jelenik meg ebben az ábrázolási technikában) (2.8. ábra). 

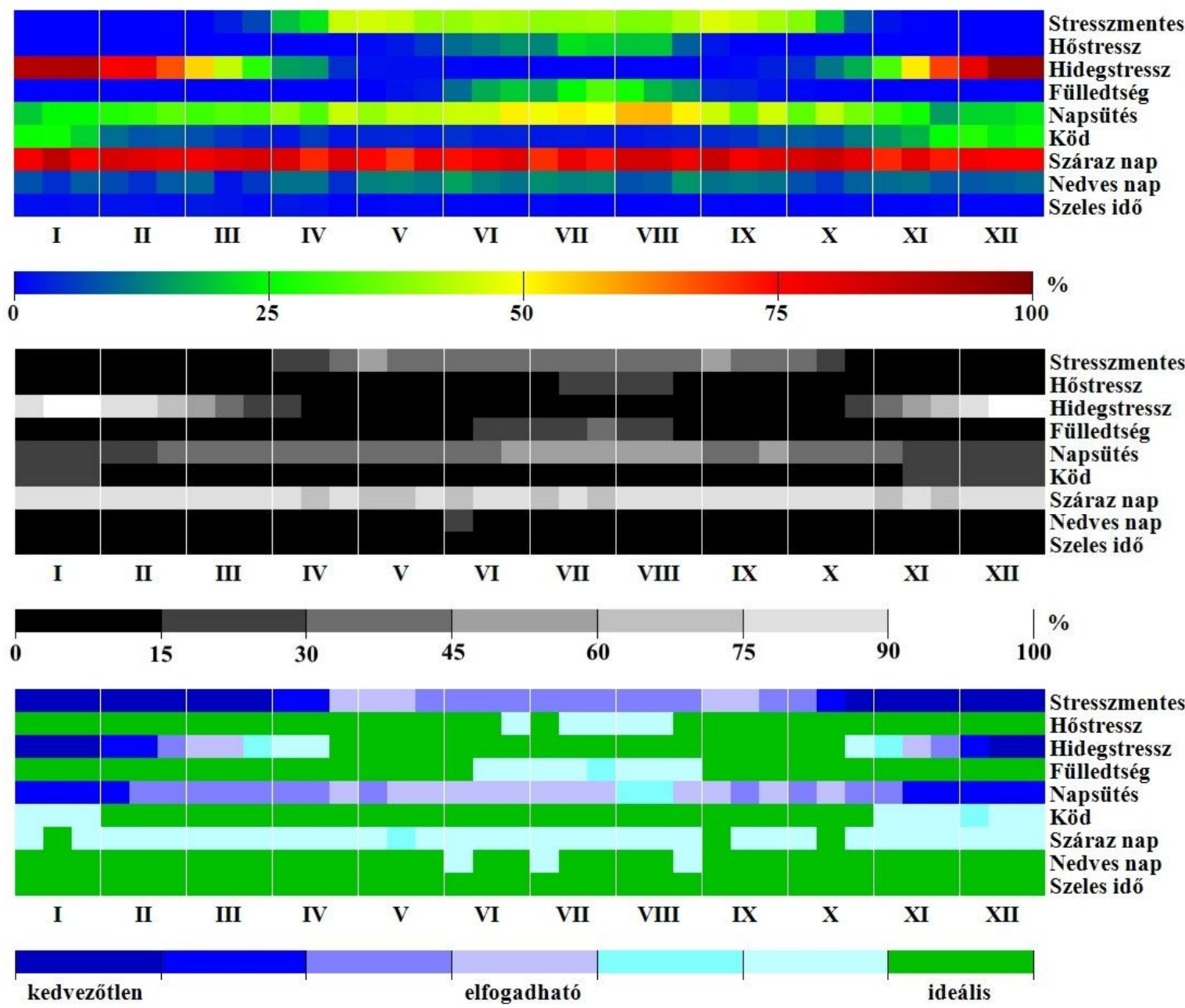

2.8. ábra: Példák a CTIS megjelenítési lehetőségeire: interpolált színskála, diszkrét színkódok, valamint hétfokozatú, turisztikai szempontú értékeléshez rendelt diszkrét színkódok (a Budapest-Pestszentlörinc meteorológiai állomás mérési adatai alapján, az 1996-2010 időszakra, tíznapos felbontásban)

A CTIS-t széles körben használják szerteágazó klimatikus viszonyok között, például tengerparti, városi vagy hegyvidéki területek jellemzésére. Szakirodalmi kutatásaim alapján ez idáig például Kréta (Matzarakis 2007), Tajvan (Lin and Matzarakis 2008), Horvátország (Zaninovic and Matzarakis 2009, Brosy et al. 2014), Ausztrália (Shiue and Matzarakis 2011), Törökország (Caliskan et al. 2012), Irán (Farajzadeh and Matzarakis 2012), Svájc (Matzarakis et al. 2012) és Luxemburg (Matzarakis et al. 2013) területére történtek CTIS-t (is) használó vizsgálatok. Endler et al. (2010) a jövőbeli hatásokat vizsgálta a CTIS alapján a Feketeerdő térségére a REMO regionális klímamodell eredményeit felhasználva. A turisták és a turisztikai szolgáltatók számára készített ún. bioklíma röplapok is tartalmaznak CTISeredményt (Zaninovic and Matzarakis 2009, Caliskan et al. 2012). 


\section{Problémafelvetés és a kutatás céljai}

\subsection{A turisztikai klíma értékelése során felmerülő hiányosságok}

A Mieczkowski (1985) által bevezetett TCI az elmúlt évtizedek során széles körben használt mérőszámmá vált a turisztikai klimatológia területén (elsősorban a könnyen hozzáférhető adatok és az egyszerü meghatározása miatt). Az utóbbi években ugyanakkor számos probléma vagy hiányosság merült fel az indexszel kapcsolatban. A hiányosságok egyrészt magából az index felépítéséből, struktúráából erednek, másrészt kritika érte abból a szempontból, hogy mennyire hitelesen használható fel a turisztikai klímapotenciál jellemzésére. A következőkben három olyan TCI-hiányosságra mutatok rá, melyeket a nemzetközi szakirodalom és a saját tapasztalataim alapján azonosítottam. Ismertetem, hogy milyen megoldást találtam a hiányosságok kiküszöbölésére (3.1. ábra).

PROBLÉMÁK, HIÁNYOSSÁGOK

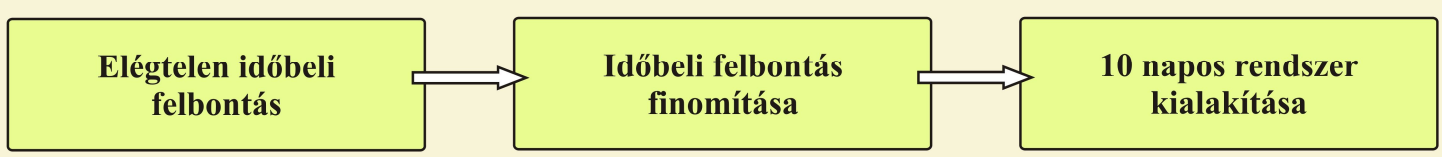

TCI

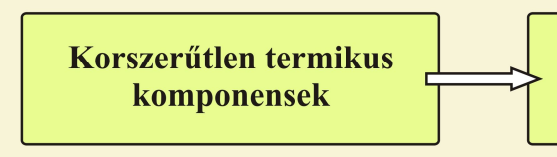

Termikus komponensek modernizálása

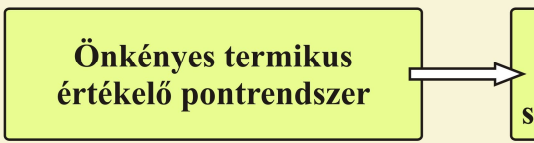

Értékelő pontrendszer hitelesítése valós szubjektív reakciók alapján
FELADAT

\section{CTIS \\ Termikus komponensek Termikus komponensek nem tükrözik a valós szubjektív reakciókat \\ hitelesítése valós szubjektív reakciók alapján \\ PET termikus percepció értéktartományok lehatárolása}

3.1. ábra: A TCI és a CTIS eszközökkel kapcsolatban felmerült hiányosságok, a problémák megoldására tett javaslatok és az elvégzett feladatok

A TCI egyik hátrányaként kiemelhető annak elégtelen időbeli felbontása (3.1. ábra). A 2.3.1. fejezetben ismertettem, hogy kiszámításához a meteorológiai változók havi átlagai szükségesek. Mieczkowski (1985) célja ugyanis az volt, hogy az index évtizedekre visszamenőleg, mindenki számára elérhető klímainformációkra épüljön. Több korszerü turisztikai klimatológiai munka ugyanakkor hangsúlyozza, hogy mivel egy átlagos üdülés időtartama általában egy-két hét (Scott and McBoyle 2001, de Freitas et al. 2008, Perch-Nielsen et al. 2010), a TCI időbeli felbontását célszerü ezzel a rövidebb időtartammal összhangba hozni (Scott et al. 2004, Matzarakis 2007, de Freitas et al. 2008, Perch-Nielsen et al. 2010). A problémával egyetértve javaslatom a 10 napos (ún. dekádos) értékelö rendszer, melyet a későbbiekben alkalmazok is a turisztikai klímapotenciál jellemzésére. 
A TCI rendszerével kapcsolatban azonosítható második probléma, hogy a termikus komponensei mögött lévő tudományos ismeret a mai tudásunk szerint már nem megfelelő, mivel nem veszi figyelembe korrekt módon a légköri környezet termikus folyamatait (3.1. ábra). A 2.3.1. fejezetben ismertettem, hogy a TCI termikus komfortot jellemző komponensei (a nappali és a napi komfortindex) az effektív hőmérsékleten alapulnak, amely a léghőmérséklet és a légnedvesség kombinált hatására épül (2.2. táblázat). A légköri környezet termofiziológiai hatása ugyanakkor ennél komplexebb módon nyilvánul meg: további termikus paraméterek, valamint személyes tényezők is befolyással vannak rá (Mayer and Höppe 1987, Jendritzky 1993, Mayer 1993, 2008, Matzarakis and Mayer 1996, VDI 1998, Höppe 1999, Ali-Toudert 2005) (2.2.4. fejezet). A problémakört felismerve több tanulmány is kiemeli, hogy a TCI termikus tagjait módosítani, korszerüsíteni szükséges (Scott and McBoyle 2001, Scott et al. 2004, Amelung and Viner 2006, Perch-Nielsen et al. 2010). Erre vonatkozóan azonban szakirodalmi ismereteim szerint érdemi elörelépés nem történt. Jómagam célszerünek tartom az effektív hőmérsékletet egy olyan termikus komfortindexre cserélni, amely valamennyi termikus és személyes tényező fiziológiai hatását egyesíti (Mayer and Höppe 1987, Höppe 1999). Erre legalkalmasabbnak a már többször szóba került PET-indexet tartom, így dolgozatom másik módszertani fejlesztéseként a PET-indexet integrálom a TCI jelenlegi termikus komponenseibe (3.1. ábra).

Számos turisztikai klimatológiai tanulmány kiemeli $\mathrm{s}$ egyben a legnagyobb TCIproblémakörnek tartja, hogy a komponenseinek - köztük a termikus tagoknak - az értékelö pontrendszerei, valamint az al-indexek súlyozása alapvetően önkényes: részben az akkor rendelkezésre álló humán-biometeorológiai szakirodalmon, részben a szerző saját szakértői meglátásán alapul (Mieczkowski 1985, Scott et al. 2004, Amelung and Viner 2006, de Freitas et al. 2008, Farajzadeh and Matzarakis 2009, Moreno and Amelung 2009, Eugenio-Martin and Campos-Soria 2010, Perch-Nielsen et al. 2010). Mindenképp szükséges az értékelő pontrendszerek és a súlyértékek hitelesítése a helyi lakosság vagy a turisták tényleges szubjektív reakciói alapján (3.2. fejezet). A dolgozat harmadik TCI-módosítással kapcsolatos célja a termikus komponenseire egy olyan értékelő pontrendszer kidolgozása, mely figyelembe veszi a tényleges szubjektív reakciókat. Mivel a második problémakör értelmében a két termikus komponensbe beillesztem a PET-indexet, a feladatom egy olyan új, PET-alapú értékelö pontrendszer kidolgozása s annak integrálása a TCI termikus komponenseibe, amely a magyar lakosság tényleges szubjektív értékeléseit veszi figyelembe, s így az index jobban igazodik a hazai klimatikus körülményekhez (3.1. ábra).

A másik részletesen vizsgált értékelő módszer, a CTIS használatakor általában tíznapos átlagos gyakoriságokat használnak a haviak helyett. Emellett létrehozásakor már figyelembe vették, hogy a termikus komponensek a mai tudásunk szerint is korszerü komfortindexen (PET) alapuljanak (2.3.3. fejezet). Ugyanakkor a CTIS-ben a termikus hatások értékelése a nyugat-közép-európai viszonyokra vonatkozó PET termikus stressz kategóriahatárokon alapul (Matzarakis and Mayer 1996, Matzarakis et al. 1999, Matzarakis 2007) (3.2. ábra, 2.5. táblázat), és ennek megfelelően használják világszerte. A CTIS-ben lévő termikus események három csoportba sorolhatók: termikus komfort (nincs termikus stressz), hőstressz és hidegstressz (2.5. és 3.1. táblázat). Megjegyzendő, hogy a CTIS stresszmentes tartományaként az európai viszonyok között általában a $18-29{ }^{\circ} \mathrm{C}$-os intervallumot javasolják és használják (2.5. és 3.1. táblázat), ami az eredeti PET-skála stresszmentes, valamint enyhe hőstressz kategóriáit foglalja magában (3.2. ábra, Matzarakis and Mayer 1996, Matzarakis et al. 1999). 
Az alkalmazott PET kategóriarendszer azonban nem tükrözi a helyi lakosság szubjektív reakcióit. Így a TCI harmadik problémaköréhez hasonlóan ez esetben is az a célom, hogy a termikus komponensek hitelesen kifejezzék a helyi - jelen esetben magyar - lakosság szubjektív reakcióit. Az ehhez kapcsolódó feladat egy olyan új PET-kategóriarendszer (küszöbértékek) felállítása és beillesztése a CTIS-be, amely a helyi lakosság által ténylegesen neutrálisnak, melegnek és hidegnek érzett körülményeket határozza meg (3.1. ábra).

\begin{tabular}{|c|c|c|c|c|c|c|c|c|c|}
\hline \multirow{3}{*}{$\begin{array}{l}\text { fiziológiai } \\
\text { stressz szint }\end{array}$} & & & 8 & 13 & 18 & & 29 & 35 & \\
\hline & $\begin{array}{l}\text { extrém } \\
\text { hideg- } \\
\text { stressz }\end{array}$ & $\begin{array}{l}\text { erōs } \\
\text { hideg- } \\
\text { stressz }\end{array}$ & $\begin{array}{c}\text { mérsékelt } \\
\text { hidegstressz }\end{array}$ & $\begin{array}{c}\text { enyhe } \\
\text { hidegstressz }\end{array}$ & $\begin{array}{c}\text { nincs termikus } \\
\text { stressz }\end{array}$ & $\begin{array}{c}\text { enyhe } \\
\text { hőstressz }\end{array}$ & $\begin{array}{l}\text { mérsékelt } \\
\text { hőstressz }\end{array}$ & $\begin{array}{c}\text { erös } \\
\text { hőstressz }\end{array}$ & $\begin{array}{c}\text { extrém } \\
\text { höstressz }\end{array}$ \\
\hline & & & 8 & 13 & 18 & & 29 & 35 & \\
\hline hőérzet & $\begin{array}{l}\text { nagyon } \\
\text { hideg }\end{array}$ & hideg & hũvös & $\begin{array}{l}\text { enyhén } \\
\text { hưvöss }\end{array}$ & neutrális & $\begin{array}{l}\text { enyhén } \\
\text { meleg }\end{array}$ & meleg & forró & nagyon forrc \\
\hline
\end{tabular}

3.2. ábra: A PET-index értéktartományai a nyugat- és közép-európai személyre kifejlesztve a fiziológiai stressz mértéke és az emberi höérzet alapján (Matzarakis and Mayer 1996, Matzarakis et al. 1999)

A CTIS-sel kapcsolatban a szakirodalom alapján egy további probléma is azonosítható, amely részben kapcsolódik az előző ponthoz. A küszöbértékekre - föként a hidegstressz és a napfénytartam esetében - ugyanis gyakran eltérő értékeket találunk, amelyek mögött alapvetően a terület karakterisztikus éghajlati különbségei állhatnak (pl. Matzarakis 2007, Lin and Matzarakis 2008, Matzarakis et al. 2012, Brosy et al. 2014, 3.1. táblázat). E probléma feloldására az előző ponthoz hasonlóan definiálni kell, hogy mik azok a küszöbértékek, melyek az adott klimatikus körülmények között a legrelevánsabbak. Ehhez egyrészt éghajlati adatsorok tanulmányozására van szükség, másrészt a küszöbértékek újradefiniálására a lakosság szubjektív reakciói alapján.

3.1. táblázat: A CTIS által vizsgált klimatológiai események definíciói néhány tanulmányban (Kovács et al. 2016)

\begin{tabular}{|c|c|c|c|c|c|}
\hline $\begin{array}{l}\text { Éghajlati } \\
\text { tényezők }\end{array}$ & $\begin{array}{l}\text { Vizsgált klimato- } \\
\text { lógiai esemény }\end{array}$ & $\begin{array}{c}\text { Alpok/Ausztria } \\
\text { (Matzarakis et } \\
\text { al. 2012) }\end{array}$ & $\begin{array}{l}\text { Horvátország } \\
\text { (Brosy et al. } \\
\text { 2014) }\end{array}$ & $\begin{array}{c}\text { Kréta } \\
\text { (Matzarakis } \\
\text { 2007) }\end{array}$ & $\begin{array}{c}\text { Tajvan } \\
\text { (Lin and Matzarakis } \\
\text { 2008) }\end{array}$ \\
\hline \multirow{4}{*}{ Termikus } & termikus komfort & \multicolumn{3}{|c|}{$18^{\circ} \mathrm{C}<\mathrm{PET}<29^{\circ} \mathrm{C}$} & $22^{\circ} \mathrm{C}<\mathrm{PET}<34^{\circ} \mathrm{C}$ \\
\hline & hidegstressz & $\mathrm{PET}<0^{\circ} \mathrm{C}$ & $\mathrm{PET}<4{ }^{\circ} \mathrm{C}$ & $\mathrm{PET}<8^{\circ} \mathrm{C}$ & $\mathrm{PET}<18^{\circ} \mathrm{C}$ \\
\hline & hőstressz & \multicolumn{3}{|c|}{$\mathrm{PET}>35^{\circ} \mathrm{C}$} & $\mathrm{PET}>38^{\circ} \mathrm{C}$ \\
\hline & fülledtség & \multicolumn{4}{|c|}{$e>18 \mathrm{hPa}$} \\
\hline \multirow{2}{*}{ Esztétikai } & napsütés ${ }^{\text {a }}$ & $n<4$ okta & \multicolumn{3}{|c|}{$n<5$ okta } \\
\hline & köd & \multicolumn{4}{|c|}{$R H>93 \%$} \\
\hline \multirow{4}{*}{ Fizikai } & száraz nap $^{\mathrm{a}}$ & \multicolumn{4}{|c|}{$p<1 \mathrm{~mm}$} \\
\hline & nedves nap & \multicolumn{4}{|c|}{$p>5 \mathrm{~mm}$} \\
\hline & szeles idő & \multicolumn{4}{|c|}{$v>8 \mathrm{~m} / \mathrm{s}$} \\
\hline & sípotenciál & \multicolumn{4}{|c|}{$h>10 \mathrm{~cm}$ és $30 \mathrm{~cm}$} \\
\hline
\end{tabular}

PET = fiziológiailag ekvivalens hőmérséklet, $e=$ vízgőzznyomás, $n=$ felhőzet mennyisége, $R H=$ relatív nedvesség, $p=$ csapadékösszeg, $v=$ szélsebesség, $h=$ hótakaró vastagsága

${ }^{a}$ néhány tanulmány fordítva definiálja: felhős égboltviszonyok ( $n>5$ okta), illetve csapadékos nap $(p>1 \mathrm{~mm})$ 


\subsection{A termikus viszonyok szubjektív értékelésében jelentkező különbségek}

A turisztikai klíma értékelésére bemutatott módszerek kialakításakor igyekeztek a légköri környezet minél több, a turizmus szempontjából releváns jellemzőjét számításba venni. A figyelembe vett paraméterek közül - mint azt a 2.1. táblázatban is feltüntettem - a termikus komponensek (léghőmérséklet, légnedvesség, szélsebesség, valamint a hőhatású sugárzási fluxusok összessége) az emberi szervezet hőháztartására hatnak (Jendritzky 1993, VDI 1998). Ezt a hatást általában hőérzeti vagy hőstressz-kategóriákban fejezi ki a szakirodalom, és az értékelés rendszerint egy standard alanyra vonatkozik, aki a teljes populációt reprezentálja. A PET-alapú értékelés általános alanya például egy 1,75 m magas, $75 \mathrm{~kg}$ súlyú, 35 éves férfi, aki könnyü ruházatot visel és mérsékelt mozgást végez (Höppe 1999).

A termikus környezet érzékelése és értékelése azonban szubjektív folyamat, tehát a különböző egyének vagy csoportok másként érzékelhetik és értékelhetik ugyanazokat a termikus viszonyokat (Knez and Thorsson 2006, 2008), amelyre a fiziológiai, fizikai és a pszichológiai alkalmazkodás (adaptáció) mechanizmusain keresztül egy sor személyes jellemző kihat ( $\mathrm{Ni}$ kolopoulou and Steemers 2003, Nikolopoulou and Lykoudis 2006).

Az emberi szervezet fiziológiailag alkalmazkodik az adott földrajzi régió éghajlatát jellemző termikus viszonyokhoz, így annak megváltozása vagy (évszakos) változékonysága különböző érzékenységet s az extrém viszonyokkal szemben eltérö toleranciát okoz (Nikolopoulou and Steemers 2003, Kántor 2016). Ez természetesen maga után vonja azt is, hogy a turisztikai utazások során az emberi szervezetnek akklimatizálódnia kell a célterületek esetlegesen eltérő éghajlati adottságaihoz.

A fizikai adaptáció alatt az egyének olyan viselkedési reakcióit értjük, mint például a ruházat típusának és rétegzettségének vagy az aktivitás mértékének (tevékenységforma) - általában az évszakokkal összefüggő - megváltozása. A fizikai alkalmazkodás érvényre jut a napnak való kitettség (expozíció) változtatásával is, amely úgyszintén befolyásolja az emberi szervezetet érő hőterhelést (Nikolopoulou and Steemers 2003, Kántor and Unger 2010). A turisztikai tevékenységek különböző formái és eltérő helyszínei, valamint az esetenként ezekkel összefüggő ruházat jellege tehát a fizikai alkalmazkodás más és más lehetőségét veti fel.

A fiziológiai és a fizikai adaptáció mellett pszichológiai alkalmazkodási mechanizmusok is megnyilvánulnak (Nikolopoulou and Steemers 2003). Így például az egyének tisztában vannak a lakóhelyük (évszakos) klimatikus adottságaival a termikus tapasztalataik alapján, s így egy bizonyos szintig tolerálják azt (pl. hazánkban a nyári meleg megszokott jelenségnek számít). Ugyancsak tudatában vannak azzal, hogy a kültéri klimatikus viszonyokat természetes úton nincs módjuk kontrollálni, amely úgyszintén a termikus érzékenységük és türőképességük szélesebb spektrumát váltja ki. (Kisebb léptékben természetesen adott esetben befolyásolhatják termikus környezetüket, pl. tengerparton napernyő alá húzódhatnak, egy beltéri helyiséget pedig klimatizálhatnak.) Kardinális szerepe van a klimatikus viszonyokkal való elégedettség alakításában az adott termikus környezet (turisztikai desztináció) és időszak (évszak) klimatikus adottságaival kapcsolatos elvárásoknak (vagyis hogy mire számíthat az egyén előzetes ismeretei szerint, és ehhez képest mit tapasztal meg ténylegesen az adott területen). A termikus viszonyokkal kapcsolatos pszichológiai adaptációs mechanizmusok közül turisztikai szempontból a legjelentősebb talán az, hogy előzetes információk révén a turista mentálisan fel tud készülni a klíma földrajzi és évszakos változékonyságára. 
A fenti adaptációs mechanizmusok jellegén és „sikerességén” az adott kultúra norma- és szabályrendszere is sok esetben nyomot hagy. Fizikai értelemben befolyásolhatja például a ruházat vagy az aktivitás formáját, de a különböző népcsoportoknak pszichológiai vonatkozásban (pl. az eltérő nevelési elvek miatt) is más és más lehet a termikus viszonyokkal kapcsolatos érzékenysége és toleranciája (Knez and Thorsson 2006, 2008, Tung et al. 2014).

A különböző személyes jellemzők (kor, nem, magasság, testsúly és különösen az egészségi állapot) fiziológiai szinten, a hőszabályozás befolyásolásán keresztül ugyancsak nagyban hozzájárulnak a termikus környezet szubjektív jellegü érzékeléséhez és értékeléséhez (Fanger 1972, Havenith 2005).

A termikus környezetre adott szubjektív reakciók és az esetleges különbségek feltárása az utóbbi körülbelül másfél évtized turisztikai klimatológiai kutatásaiban is egyre nagyobb szerephez jut. A felmérések elsősorban a turisták vagy a helyi lakosok különböző meteorológiai alapparaméterek szerinti szubjektív értékeléseinek (percepciók, preferenciák ${ }^{3}$, érzékenységek) feltárására irányulnak. Sok esetben meghatározzák azokat a klímaparamétertartományokat, amelyeket a turisták optimálisnak, elfogadhatónak vagy éppen elfogadhatatlannak értékelnek. Vizsgálják, hogy mely klímaparaméter milyen relatív fontossággal bír a turisták értékelése alapján, s egyáltalán az éghajlat mint motivációs tényező mekkora szerepet játszik a célterületek felkeresésében.

A fenti vizsgálatokat gyakran jól meghatározott piaci szegmensek szerint csoportosítva végzik, vagyis például a kérdőíveken rákérdeznek az egyének lakóhelyére vagy életkorára, majd statisztikai módszerekkel megvizsgálják a közöttük jelentkező különbségeket. Az eredmények alapján a szubjektív értékelések között különbségek mutathatók ki a fizikai környezettől és a turisztikai tevékenység típusától függően (pl. városi, tengerparti, hegyvidéki turizmus és az itt jellemző tevékenységformák) (Kozak 2002, Scott et al. 2008, Rutty and Scott 2010, 2015). Ugyancsak különbségeket azonosítottak az eltérő nemzet, származási helyszín (Morgan et al. 2000, Kozak 2002, Vigotti et al. 2006, Mansfeld et al. 2007, Scott et al. 2008, Moreno 2010a, Rutty and Scott 2013, 2015, Lindner-Cendrowska and Blazejczyk 2016), valamint a korosztály és a nem (Rutty and Scott 2015, Lindner-Cendrowska and Blazejczyk 2016) alapján, s attól függően is, hogy egy adott populáció beföldi vagy nemzetközi turizmusban vesz-e részt (Rutty and Scott 2016).

Napjainkig a szakirodalom legnagyobb része a termikus komfortindexek és a turisztikai klímát értékelő mutatók standard formáját használja. Ez a TCI esetében a már említett önkényes értékelö pontrendszerek és súlyozás használatát jelenti (példaként hivatkozható az összes, a 2.3.1. fejezetben felsorolt, TCI-t használó forrás). Az általam nem vizsgált CIT esetében az a probléma, hogy a standard értékelő mátrixa (2.4. táblázat) csak egy adott nemzet és korosztály „ex-situ” módon felmért és csak egyetlen tevékenységre vonatkozó értékelését tartalmazza (ilyen használatra példa: Amengual et al. 2012). Ezt viszont nem célszerű változatlan formában alkalmazni minden nemzetre, korcsoportra és turisztikai tevékenységre. Ezenfelül egy a konkrét helyszínen kivitelezett (,in-situ”) felmérés (p1. Rutty and Scott 2013, 2015, Lindner-Cendrowska and Blazejczyk 2016) pontosabb képet ad, mint a fiktív helyszín képzeletén alapuló értékelés.

A problémakör során kiemelt fontossággal bír a PET-index, hiszen széles körben használják a termikus komfortkutatásokban, illetve több turisztikai értékelö módszerben (pl. CIT,

\footnotetext{
3 A preferencia a különböző meteorológiai paraméterek bizonyos értéktartományaira vonatkozó szubjektív igény, a velük kapcsolatban kívánt ideális állapot (Oliveira and Andrade 2007).
} 
CTIS) is megtalálható (3.3. ábra). A 3.1. fejezetben említettem, hogy a PET standard kategóriahatárai egy nyugat- és közép-európai személy fiziológiai reakcióin alapulnak (3.2. ábra). Elegendő az elmúlt néhány év publikációi közül válogatni, ezek között is nagyszámú példát találhatunk a hagyományos PET-értéktartományok használatára. Így humán-biometeorológiai vonatkozásokban például Charalampopoulos et al. (2013), Nastos and Matzarakis (2013), Giannaros et al. (2015), Vitt et al. (2015), Basarin et al. (2016) vagy Roshan et al. (2016b), míg turisztikai klimatológiai célokra például Matzarakis et al. (2010b, 2012), Ndetto and Matzarakis (2013) vagy Brosy et al. (2014) használta. A CTIS-ben pedig eredeti PETküszöbértékeket alkalmazott például Zaninovic and Matzarakis (2009), Shiue and Matzarakis (2011), Caliskan et al. (2012), Farajzadeh and Matzarakis (2012) vagy Matzarakis (2014).

Az univerzálisan használt kategóriatartományokon túl az is problémát jelent, hogy a PETet bevezető publikációk ugyanazokat a küszöbértékeket definiálták a különböző fokú termofiziológiai stressz és egyéni hőérzet jellemzésére. E tanulmányok mind a stresszmentes körülményekre, mind a neutrális hőérzetre $18-23{ }^{\circ} \mathrm{C}$-os PET-tartományt határoztak meg. Hasonlóan a $23-29{ }^{\circ} \mathrm{C}$-os intervallum mind az enyhe hőstresszviszonyokat, mind az enyhén meleg hőérzetet tükrözi (3.2. ábra, Matzarakis and Mayer 1996, Matzarakis et al. 1999). A PET-et használó szakirodalom nagy részében pedig a későbbiekben e két fajta megközelítésmód használata gyakran keveredik, nem konzisztens. A valóságban viszont a PET termikus stresszkategóriák és az egyének aktuális höérzete általában nem esik egybe, így ekvivalens értelemben való használata nem megfelelö (Lin and Matzarakis 2008, Kántor et al. 2012, Cohen et al. 2013, Yang et al. 2013b, Lai et al. 2014, Kovács et al. 2016). Például az eredeti PET-kategóriahatárok egy szubtrópusi területen élő egyén szemszögéből felülbecsülhetik a meleg termikus viszonyokra vonatkozó érzékenységüket, ugyanakkor alábecsülhetik a hidegre való érzékenységüket (Kántor et al. 2016a).

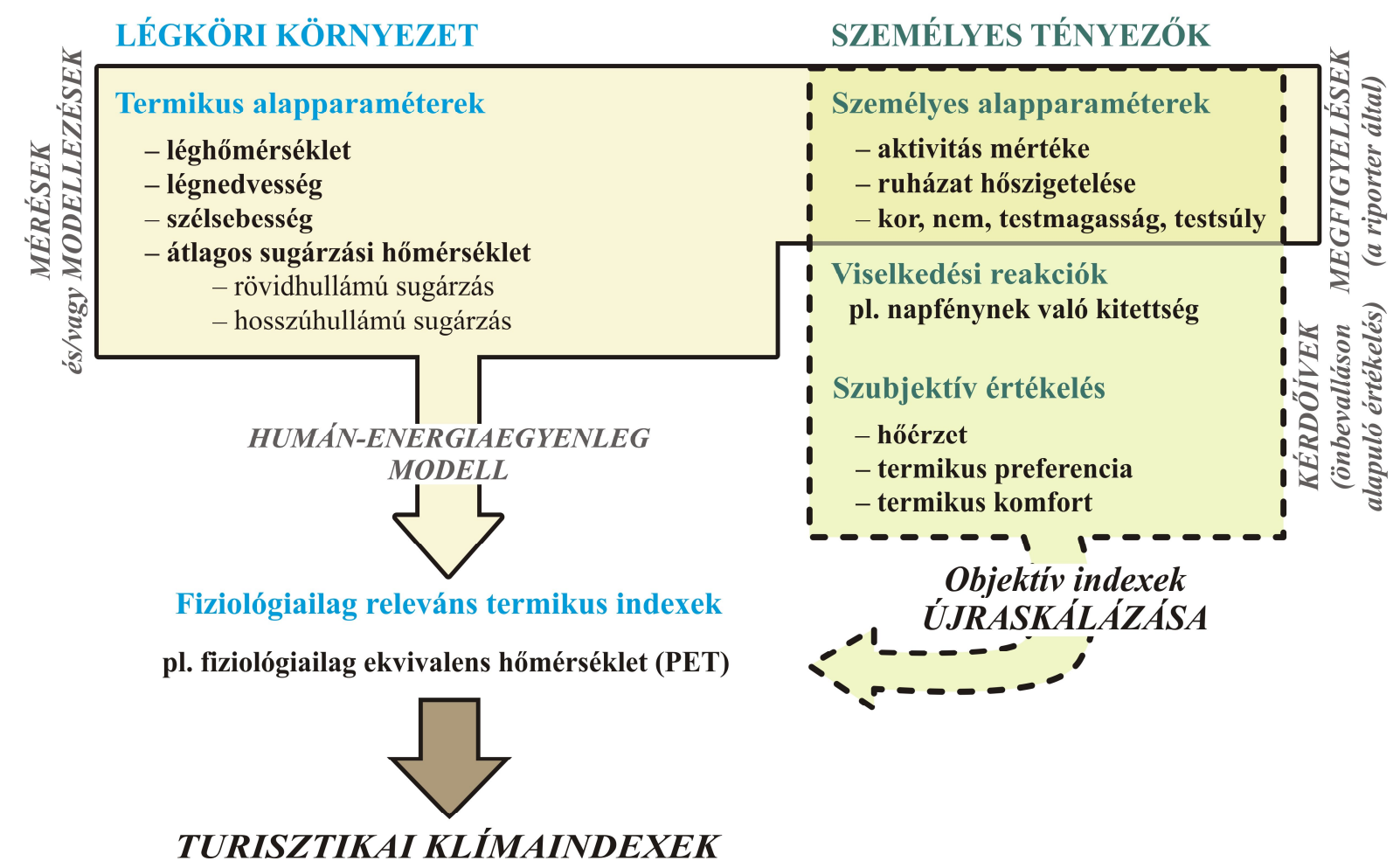

3.3. ábra: A komfortindexek újraskálázásának szerepe a termikus komfortviszonyok és a turisztikai klímapotenciál hiteles leírása céljából (Toy and Kántor 2016 után módosítva) 
Felvetődik tehát a kérdés, hogy a humán-biometeorológiai vagy a turisztikai klimatológiai mutatók univerzális használata - figyelmen kívül hagyva a helyi lakosság vagy a turisták tényleges reakcióit - korrekt értékelést tesz-e lehetővé a termikus komfortviszonyok vagy a turisztikai klímapotenciál vonatkozásában (3.3. ábra). E problémakörre már több tanulmány is rávilágított (Spagnolo and de Dear 2003, Knez and Thorsson 2006, 2008, Meze-Hausken 2008, Kántor 2012, Kántor et al. 2012, 2016a, Lin et al. 2015, Rutty and Scott 2015, Kovács et al. 2016, Toy and Kántor 2016), és napjainkra egyre inkább teret hódít a klimatikus viszonyokra adott szubjektív reakciók sajátosságainak megismerése. A közöttük lévő különbségek hatására pedig egyre nagyobb a törekvés, hogy a termikus komfortindexek és a turisztikai klíma értékelésére használt módszertant (skála, pontrendszer, küszöbértékek) megkíséreljük a helyi lakosság vagy a turisták reakcióival összhangba hozni.

\subsection{Magyarországi előzmények}

\subsubsection{Turisztikai desztinációk klímapotenciáljának értékelése}

A fenntartható turizmusfejlesztés egyik kulcstényezője, hogy tisztában legyünk azzal, hogy a különböző turisztikai tevékenységek éghajlati feltételei megfelelőek-e egy adott régióban. A kedvező klimatikus adottságokkal rendelkező fogadóterületek versenyelönybe kerülhetnek a többi desztinációhoz képest. A klímapotenciál ismeretében a turisztikai szolgáltatók a kínált termékeket és szolgáltatásokat optimálisabban tudják kialakítani és elosztani, míg az utazók a megfelelő helyszínt és időpontot, illetve tevékenységformát optimálisabban tudják kiválasztani. Egy adott régió klímapotenciáljának vizsgálatához célszerüen a területen elhelyezkedő meteorológiai állomások éghajlati adatsorainak elemzése és a turisztikai mérőszámok számítása teremt egy megfelelö lehetőséget.

A komplexebb turisztikai klimatológiai mutatókon alapuló vizsgálatok száma hazánk területére vonatkozóan egyelőre alacsony, holott a téma fontossága, hiánypótló szerepe indokolja az ilyen jellegü kutatásokat. A Szegedi Tudományegyetem (SZTE) Éghajlattani és Tájföldrajzi Tanszékén jómagam, az Országos Meteorológiai Szolgálatnál (OMSZ) pedig elsősorban Németh Ákos dolgozik a témában. A kutatások egyik csoportját hazai és európai turisztikai desztinációk éghajlati feltételeinek vizsgálata alkotja. Valamennyi értékelésben a nemzeti meteorológiai szolgálatok mérőállomásainak mért adatait használják fel a mutatók meghatározásához.

Az OMSZ-ban folytatott vizsgálatok részeként elsőként Németh (2013) a TCI és a CTIS, majd pedig Németh (2015) a CIT alakulását vizsgálta Siófokra vonatkozóan. A CITértékeléskor a Bafaluy et al. (2014) által kialakított, tevékenységspecifikus tipológiai mátrixokat alkalmazta (2.3.2. fejezet). Vitt (2012) és Vitt et al. (2015) pedig a tanszékünkön végzett munkája eredményeként a CTIS-t használta Szegedre a belvárosi és a külterületi klimatikus viszonyok összehasonlítására.

Jómagam hazánkban elsőként a hagyományos eszközöket megkíséreltem a hazai lakossághoz adaptálni, elsősorban a termikus értékeléseiket figyelembe véve. Korábbi munkáimban a TCI egy kezdeti módosított verzióját dolgoztam ki, és az alapján négy hazai és két egyéb európai célterületre elemeztem a klímapotenciál alakulását. E módosított TCI termikus komponenseibe már integráltam a PET-indexet, viszont az értékelő pontjai még nem tényleges szubjektív reakciókon alapultak (Kovács and Unger 2013, 2014a, 2014c). A későbbiekben kidol- 
goztam a TCI egy újabb módosított változatát, amely már a magyar lakosság termikus viszonyokkal kapcsolatos értékelését tükrözte. Ezzel az indexváltozattal négy (Kovács and Unger 2014b), illetve három (Kovács et al. 2016) magyar célterületre értékeltem a klímapotenciál alakulását. Az eredeti és a módosított index alakulását két hazai város példáján összehasonlítottam (Kovács et al. 2015). Újabb irányként pedig a TCI-on felül a CTIS-t is bekapcsoltam vizsgálataimba, melyben az eredeti és a magyar lakossághoz adaptált PET-kategóriarendszert is alkalmaztam (Kovács et al. 2016). E tanulmányokhoz hasonlóan disszertációm 6.1. fejezetében is mutatok példákat turisztikai desztinációk értékelésére az eredeti és a módosított TCI és CTIS alapján.

Hazánkban a turisztikai indexek első térképes megjelenítésére az OMSZ kötelékében került sor, Hódos (2014) munkájához kapcsolódóan. Vizsgálatában az eredeti TCI térbeli eloszlásának alakulását elemezte a Kárpát-régióra $\left(44-50^{\circ} \mathrm{E}\right.$ és $\left.17-27^{\circ} \mathrm{K}\right)$. A vizsgálati területe megegyezett a nemzetközi CarpatClim projekt által lefedett célterülettel (Szalai et al. 2013). E projekt keretében létrejött a Kárpát-régióra vonatkozóan egy $0,1^{\circ} \times 0,1^{\circ}(\mathrm{kb} .10 \mathrm{~km} \times 10 \mathrm{~km})$ horizontális térbeli felbontású, napi felbontású rácsponti adatbázis az 1961-2010 időszakra, amely számos meteorológiai alapváltozót és származtatott indikátort tartalmaz. A rácsponti értékek előállítása ellenőrzött, homogenizált mérési adatokból történt, melyeket a $0,1^{\circ}$ felbontású rácsra interpolálták s az országhatárok mentén harmonizálták. A homogenizálás egy matematikai alapokon nyugvó eljáráson és számítási programrendszeren, a MASH-on (Multiple Analysis of Series for Homogenization) alapult (Szentimrey 2011). Az interpoláció folyamata pedig a MISH (Meteorological Interpolation based on Surface Homogenized Data Basis) matematikai statisztikai alapokon nyugvó interpolációs rendszerrel történt (Szentimrey and Bihari 2007). Mindkét eljárást az OMSZ-ban fejlesztették ki és alkalmazták. Hódos (2014) az így előállított CarpatClim-változókból számolta ki a TCI-értékeket, majd térképes formában ábrázolta.

\subsubsection{Az éghajlatváltozás turizmusra gyakorolt hatásának vizsgálata}

Magyarország gazdasági-társadalmi helyzetét számottevően befolyásolják a hosszú távú globális folyamatok, közülük is főként a klíma-, az energia-, az élelmiszer- és a vízbiztonság problémakörei. Hazánkban különböző természetü, számos okra visszavezethető folyamatok eredményeként területi egyenlőtlenségek figyelhetők meg, amelyek az éghajlatváltozás és más begyürüző globális változások hatására tovább mélyülhetnek, mivel az egyes régiók és társadalmi rétegek más-más módon és mértékben sérülékenyek a változásokkal szemben (Pálvölgyi et al. 2010). Az éghajlatváltozáshoz való alkalmazkodás területi és ágazati stratégiai integrációja széles körü információkat igényel a változásokkal szembeni területi szintü, társadalmi, gazdasági és környezeti sérülékenységről. A hazai szakpolitikai döntéshozók számára különösen fontos az éghajlatváltozás megelőzése mellett a következményekhez való adaptáció feltételeinek megteremtése, a klímaváltozás által szolgáltatott lehetőségek kiaknázása, és szükséges esetén a mitigációs intézkedések meghozatala vagy hatékonyabb megvalósítása (Uzzoli 2015). Ugyanakkor mind a mai napig alig rendelkezünk olyan összehangolt vizsgálatokkal, amelyek az éghajlatváltozás különböző szakterületekre kifejtett hatását célozzák, s egy összehangolt adaptációs stratégia kidolgozását segítik elő. A célirányos alkalmazkodási stratégia kialakításához elkerülhetetlen egy olyan objektív alapú hatásvizsgálati módszertan kialakítása, amely alapján az egyes szektoroknak a klímaváltozás hatásainak való ki- 
tettségét, alkalmazkodási képességét és sérülékenységét objektív módon számszerüsíteni lehet.

A hazai éghajlat-változási sérülékenységvizsgálatok alapjait Pálvölgyi et al. (2010) teremtette meg. A CLAVIER nemzetközi klímakutatási projekt keretében elkészítették az ún. CIVAS-modellt (Climate Impact and Vulnerability Assessment Scheme), mely egységes fogalmi és módszertani kereteket biztosít a kvantitatív éghajlati hatásvizsgálatokhoz. A modell az IPCC harmadik és negyedik értékelö jelentésében közzétett megközelítésen alapul. A sérülékenység fogalmi kereteit és a modell elvi felépítését a 3.4. ábra illusztrálja. A modell az éghajlat-változási sérülékenységet egy komplex mutatóként írja le, amely a kitettség, az érzékenység és az alkalmazkodóképesség integrálásával meghatározza az éghajlatváltozás okozta komplex természeti, gazdasági és társadalmi sérülékenységet (Pálvölgyi et al. 2010). A modell egyik kezdeti lépcsőjét minden esetben a kitettség (exposure) meghatározása adja, amely az adott földrajzi helyre vonatkozó éghajlati feltételeken és ezek megváltozásán alapul. A kitettségre vonatkozó számszerü értékeket a regionális klímamodellek becslései szolgáltatják, így az objektív alapú hatás- és sérülékenységvizsgálatok egyik fontos eleme a klímamodellekből nyerhető információ.

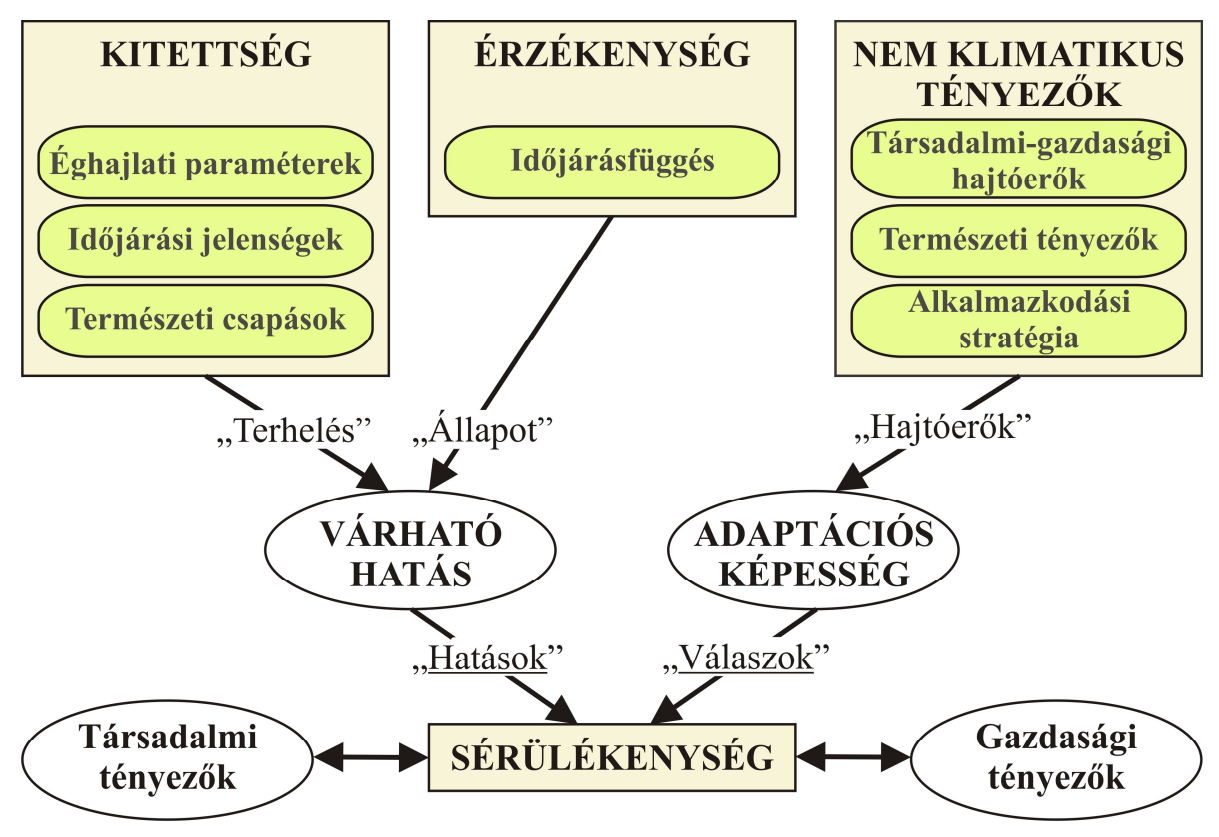

3.4. ábra: A CIVAS-modell felépítése (Pálvölgyi et al. 2010)

Az egyik legújabb, éghajlat-változási sérülékenységgel kapcsolatos nemzetközi projekt a 2015 májusa és decembere között kivitelezett KRITéR („A klímaváltozás okozta sérülékenység vizsgálata, különös tekintettel a turizmusra és a kritikus infrastruktúrákra”) elnevezésű program volt, melyben jómagam is részt vettem. A projekt egyik célja egy olyan módszertan kidolgozása volt, amely alapján hazánk területén különféle ágazatoknak a klímaváltozás hatásának való kitettségét, érzékenységét, alkalmazkodási képességét és végső soron sérülékenységét objektív módon számszerüsíteni lehet (KRITéR 2015). A cél eléréséhez megfelelő indikátorok kidolgozására volt szükség. A projekt három fókuszterületét a környezet-egészségügy (a höhullámok okozta többlethalálozásra vonatkozó vizsgálatok), a kritikus infrastruktúra (a szélsőséges időjárási helyzetek közúti balesetekre gyakorolt hatásának vizsgálata) és a turizmus (a klimatikus viszonyok turizmusra gyakorolt hatásának vizsgálata) képezte. 
A 2.2.2. fejezetben vázoltam, hogy napjainkra széles körü tudományos konszenzus alakult ki azzal kapcsolatban, hogy az éghajlatváltozás hatást gyakorol a turizmus szektorra, és a turisztikai desztinációk valamilyen mértékben sérülékenyek e hatásokkal szemben. Ennek vizsgálata létfontosságú, hiszen a turizmus amellett, hogy az egyik legfontosabb és növekvő jelentőséggel bíró nemzetgazdasági ágazat, rendkívül érzékenyen reagál az éghajlatváltozás következményeire. Hazánkban az éghajlatváltozás turizmusra gyakorolt sérülékenységének a vizsgálatát Csete et al. (2013) alapozta meg, aki a CIVAS-modell alapján Magyarország turisztikai régióira meghatározta az ország legfontosabb turisztikai kínálataira vonatkozó sérülékenységek mértékét. Kitettségi klímaindikátorként összesen tizenegy mennyiséget használt fel a sérülékenységek meghatározásához, mégpedig a nemzetközi meteorológiai gyakorlatban használt hőmérsékleti, csapadék, nedvesség, napfénytartam és szélsebesség küszöbértékeket (Csete et al. 2013). Ugyanakkor e klímaindikátorok nem klímamodellek eredményeként integrálódtak a modellbe, hanem a rendelkezésre álló szakirodalomra támaszkodva értékelték őket.

Az említett KRITéR projekt keretében a turizmus területére vonatkozóan a CIVAS-modell kitettségre vonatkozó elemét valósítottuk meg. Hazánkban elsőként a turisztikai klímaindikátorainkat (az eredeti és a módosított TCI-t, valamint a CIT-t) használtuk kitettségi indikátorokként, amelyekből jómagam az eredeti és a módosított TCI számításait végeztem. A vizsgálatban mért meteorológiai adatokat és regionális klímamodell adatokat használtam, s a vizsgált terület felbontása Magyarország járási szintje volt. (A részletes módszertant a 4.2.2. fejezet tartalmazza.)

\subsection{Kutatási célok kitúzése}

A 3.1-3.3. fejezetben vázolt problémakörökre épülve disszertációmban az alábbi célokat tüzöm ki és a következő feladatokat végzem el (3.1. és 4.1. ábra):

\section{A turisztikai klimatológia módszertanának fejlesztése és a magyar lakossághoz történő adaptálása}

a) A TCI időbeli felbontásának finomítása;

b) A TCI termikus komponenseinek korszerüsítése;

c) A TCI termikus komponenseinek hitelesítése a magyar lakosság szubjektív reakciói alapján;

d) A CTIS termikus komponenseinek hitelesítése a hazai lakosok szubjektív reakciói alapján.

Az alcélok eléréséhez a következő feladatokat végzem el:

a) A TCI tíznapos időbeli rendszerének kialakítása (és ehhez kapcsolódóan a csapadék al-index értékelő pontrendszerének módosítása);

b) Módszertani fejlesztés kidolgozása, amellyel a PET-index integrálható a TCI jelenlegi termikus komponensei helyére;

c) A magyar lakosság termikus környezetre adott szubjektív reakcióinak feltérképezése, majd a TCI termikus komponenseire új értékelő pontrendszer kialakítása; 
d) Új PET-értéktartományok lehatárolása, majd a hazai lakosok által neutrálisnak, melegnek és hidegnek érzett zónák (PET-küszöbértékek) integrálása a CTIS termikus komponenseihez.

A magyar lakosság szubjektív értékeléseinek vizsgálatát évszakonként elkülönítve, integrálásukat a két eszközbe pedig az évszakos különbségek figyelembevételével végzem. Tehát a TCI esetében évszakonként változó PET-alapú pontrendszert alakítok ki, míg a CTIS-hez évszakonként változó PET-kategóriarendszert hozok létre. Az értékelő eszközök adaptálásához felhasznált adatbázis előállításának bemutatása a 4.1.1. fejezetben történik, a TCI módosításának és adaptálásának, valamint a CTIS adaptálásának módszertani koncepciója pedig a 4.1.2. fejezetben kerül ismertetésre. A hazai lakosok termikus értékelésének sajátosságait az 5.2. fejezetben, az elöállított módosított és/vagy adaptált turisztikai eszközöket pedig az 5.3. fejezetben mutatom be.

\section{Az értékelő eszközök alkalmazása}

a) Hazai és európai turisztikai célterületek jelenlegi turisztikai klímapotenciáljának jellemzése az eredeti és a módosított TCI, valamint a CTIS alapján;

b) A turizmus szektor klímaváltozásnak való kitettségének számszerüsítése a TCI és a módosított TCI alapján.

A két alkalmazási példához felhasznált meteorológiai és klimatológiai adatbázis bemutatása és az indexek előállításának ismertetése a 4.2. fejezetben történik. Az alkalmazási példák eredményeit a 6. fejezet tartalmazza. 


\section{Adatbázisok és módszertani fejlesztés}

\subsection{A turisztikai klíma értékelésének adaptálása a magyar lakossághoz}

A TCI és a CTIS hitelesítése a magyar lakosság szubjektív reakciói alapján elsőként magának a termikus környezetre adott szubjektív reakcióknak a feltérképezését igényli (3.1-3.2. fejezet, 3.1. ábra). A termikus viszonyokra adott - meghatározott populációra jellemző szubjektív értékelési minták feltárása általában két, egymással párhuzamosan végzett felméréssorozaton alapul (4.1. ábra). Az egyik során a termikus környezet paramétereit rögzítik a vizsgálati helyszínen speciális előírásoknak megfelelő, mikro-biometeorológiai mérések keretében. A másik felméréssorozat a területre látogatók szubjektív (egyéni) reakcióinak vizsgálatát foglalja magában, melynek felvételezése általában kérdőívek alkalmazásával történik. Az objektív (mérési) adatok (és az ezekből kiszámolt komfortindexek), valamint a pillanatnyi szubjektív reakciók összevetése által tárhatjuk fel az adott populációra jellemző értékelésmintázatokat (ún. thermal assessment patterns) (4.1. ábra). Objektív mérőszámként szolgálhat maga a léghőmérséklet $\left(T_{a}\right)$ is, de a hitelesebb értékelés érdekében célszerü inkább egy komplex termikus indexet alkalmazni (pl. PET) (Függelék 1. táblázat). Szubjektív mérőszámként használhatjuk a höérzetet (thermal sensation vagy thermal perception), a termikus viszonyokkal kapcsolatos preferenciát (thermal preference), de kérdőívünkben rákérdezhetünk akár a termikus viszonyokkal kapcsolatos elégedettségre vagy azok elfogadhatóságára is (thermal suitability vagy thermal acceptance).

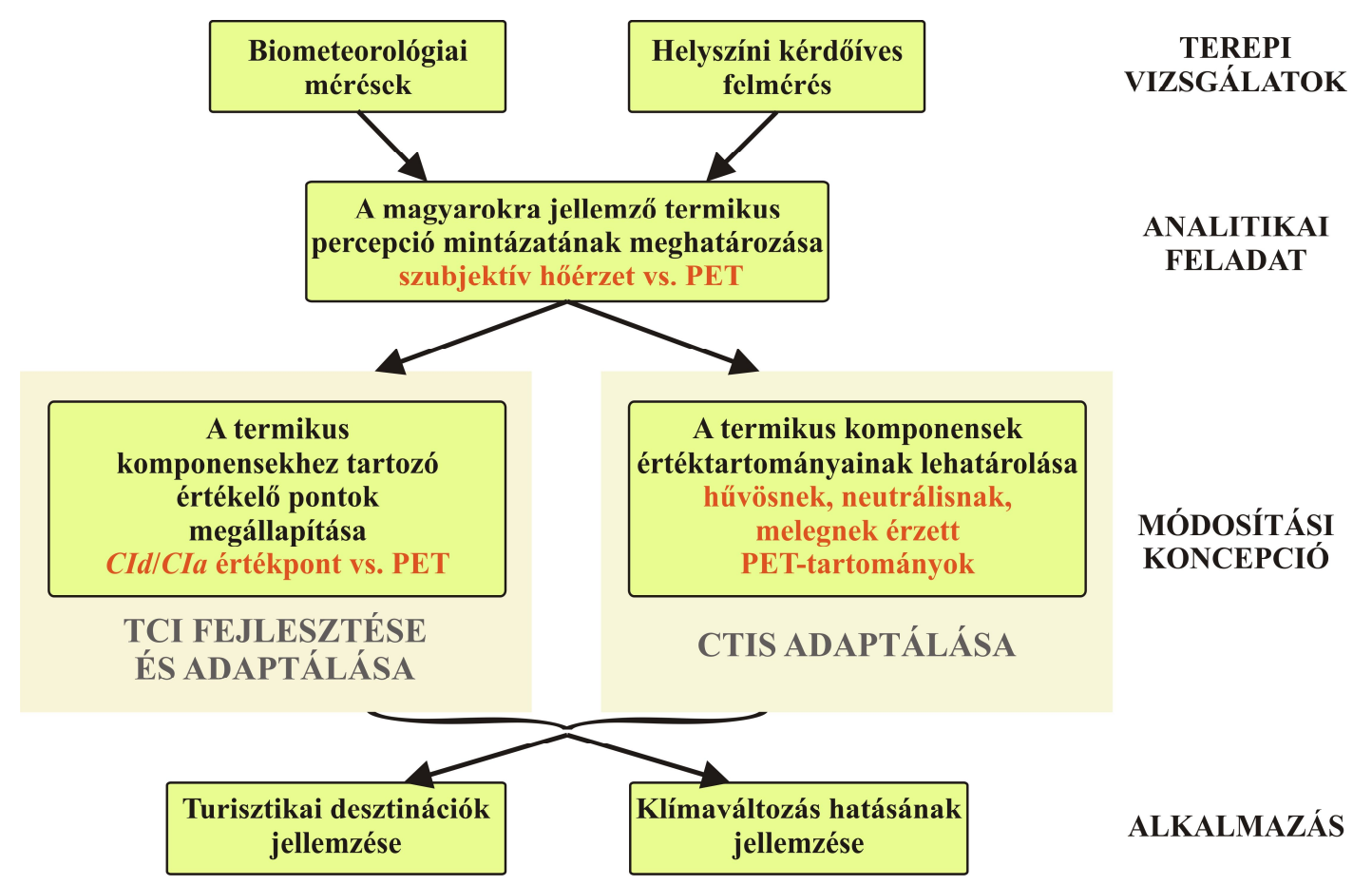

4.1. ábra: A dolgozat eredményeinek vázlatos felépítése a terepi felméréstől az alkalmazási példák bemutatásáig

A hazai lakosok szubjektív reakcióinak feltérképezéséhez egy hosszú távú, Szegeden végzett szabadtéri humánkomfort mérési kampány adatait használtam fel. A következő alfejezetben a terepi mérések során felvételezett adatbázist ismertetem, amely a bázisát képezi a turisztikai értékelő eszközök adaptálásának. 
Mielőtt azonban tovább haladnék ezen a vonalon, fontosnak tartom újfent hangsúlyozni, hogy - a 3.2. fejezetben részletezett adaptációs mechanizmusok révén - a szubjektív értékelések során „semlegesnek” vagy „kellemesnek” („komfortosnak”) ítélt termikus viszonyok az esetek többségében nem esnek egybe a különféle indexek (pl. a PET) által „stresszmentesnek” definiált termikus viszonyokkal. Dolgozatomban a magyar lakosság hőérzeti mintázatait vizsgálom, külön figyelmet fordítva a „neutrálisnak”, a „hüvösnek” és a „,melegnek” érzett tartományok meghatározására, mégpedig évszakos felbontásban. A 3.2. ábrán feltüntetett eredeti PET-kategóriahatárokat dolgozatom további részeiben a termofiziológiai stressz mértékének leírására használom (,stresszmentes”, „hőstressz” vagy „hidegstressz” állapotaként). E stresszkategóriák határai mindegyik évszakban ugyanazok, s nem szándékozom őket módosítani, hiszen ahhoz sokkal részletesebb, fiziológiai vizsgálatokra lenne szükség.

\subsubsection{Szegedi felmérések}

\section{A felmérések általános keretei}

Szeged $\left(46^{\circ}\right.$ É, $\left.20^{\circ} \mathrm{K}\right)$ Magyarország délkeleti részén, a Dél-Alföld régióban helyezkedik el. Az ország harmadik legnépesebb városa, lakosainak száma közel 163000 fö. Közigazgatási területe $281 \mathrm{~km}^{2}$, ebből a városi, elővárosi területek $40 \mathrm{~km}^{2}$-t tesznek ki. Beépítettsége a sürün elhelyezkedő középmagas (2-es lokális klímazóna - LCZ2) területtől az alig beépített (LCZ 9) területekig terjed (Lelovics et al. 2014, Unger et al. 2014). A város sík területen fekszik (tengerszint feletti magassága 75-85 m között változik), ami biztosítja a kis léptékü mikrometeorológiai eredmények általánosítási lehetőségeit (Andrade and Vieira 2007).

Köppen éghajlat-osztályozási rendszere szerint - amely figyelembe véve a növényföldrajzi sajátosságokat, a csapadék és a léghőmérséklet éven belüli változásán és összegén alapul - a város térsége a $C f$ osztályba sorolható, ami meleg-mérsékelt éghajlati viszonyokat és egyenletes csapadékeloszlást jelent. A Trewartha-féle kategorizálás alapján, amely még inkább kiemeli a növényzeti adottságokat, Szeged a D.1. osztályba tartozik: kontinentális éghajlat hoszszabb meleg évszakkal (Péczely 1979). Szeged sokévi középhőmérséklete az 1981-2010-es éghajlati normálidőszak adatai alapján $10,9{ }^{\circ} \mathrm{C}$, a napi maximum-hőmérsékletek átlaga 16,6 ${ }^{\circ} \mathrm{C}$, a minimumoké pedig $5,9^{\circ} \mathrm{C}$. A csapadék sokévi összege $514 \mathrm{~mm}$, a napfénytartam 2049 óra (OMSZ 2015a). A havi középhőmérséklet áprilistól októberig $10{ }^{\circ} \mathrm{C}$ felett alakul, a maximum-hőmérséklet pedig megközelíti vagy meghaladja a $20^{\circ} \mathrm{C}$-ot, így ez az időszak tekinthető a legalkalmasabbnak szabadtéri (turisztikai) tevékenységek szempontjából. Mivel Szeged Magyarország egyik legmelegebb városa, napjaink Kárpát-medencére prognosztizált melegedő tendenciája révén (Krüzselyi et al. 2011, Pongrácz et al. 2013, Bartholy et al. 2014, Szépszó 2014, Belda et al. 2015, Csorvási et al. 2016) városklímája intenzíven érintett a klímaváltozás által.

Az SZTE Éghajlattani és Tájföldrajzi Tanszékének városklíma-kutatócsoportja (UCRG 2015 ) - melynek 2012 óta jómagam is tagja vagyok - 2006 óta végez komplex humánbioklimatológiai felméréseket (pl. Égerházi et al. 2013a, 2013b, 2014, Kántor 2016, Kántor et al. 2012, 2016a, 2016b, Kovács et al. 2014, 2016, Takács et al. 2016). A legkiterjedtebb mérési kampány - melynek adatait a dolgozatomhoz felhasználom - elsősorban 2011 és 2012-ben kivitelezett köztéri méréseket foglal magában, amit 2015-ben újabbakkal egészítettünk ki. 
A terepi felmérések 2011 és 2012-ben márciustól októberig zajlottak. Mivel a májusjúniusi hónapokban a humánerőforrás hiánya miatt kisebb számban születtek mérési eredmények, 2015 folyamán kiegészítettük adatbázisunkat e két hónap adataival a korábbiakban teljesen megegyező mérési szisztéma alapján. A téli időszakban azért nem végeztünk méréseket, mert ekkor a területeken időző látogatók száma (akár a helyi lakosság, akár a turisták vonatkozásában) minimális, s így a szabadtéri termikus komfort vagy a turisztikai klíma vizsgálata szempontjából ez az időszak nem bír számottevő jelentőséggel ezen az éghajlaton. A felmérések kivitelezésében a tanszéki munkatársakon kívül számos egyetemi hallgató és demonstrátor is segítségünkre volt, jómagam pedig 2012 őszétől kapcsolódtam be a felmérésekbe.

A mérési időszakban Szeged hat, frekventált területen lévő, nagy számban látogatott közterületét mértük fel: a közkedvelt sétálóutca, a Kárász utca és a szervesen hozzátartozó Klauzál tér együttesét, a város központi tereiként szolgáló, rendkívül gyakran látogatott Dugonics teret és Széchenyi teret, továbbá a Szent István teret, valamint az elsősorban játszótérként funkcionáló, parkos Honvéd teret és Retek utcai játszóteret (4.2. ábra). A területek rendkívül sokféle térkialakítással rendelkeznek, változatos felszín- és vegetációborításúak, így a kis léptékű humán-biometeorológiai viszonyok széles skálája tud érvényesülni a területeken. $\mathrm{Az}$ adatgyüjtésnél arra törekedtünk, hogy az egyes mintaterületeken lehetőleg mind a három vizsgált évszakban (tavasz, nyár, ősz) végezzünk méréseket.
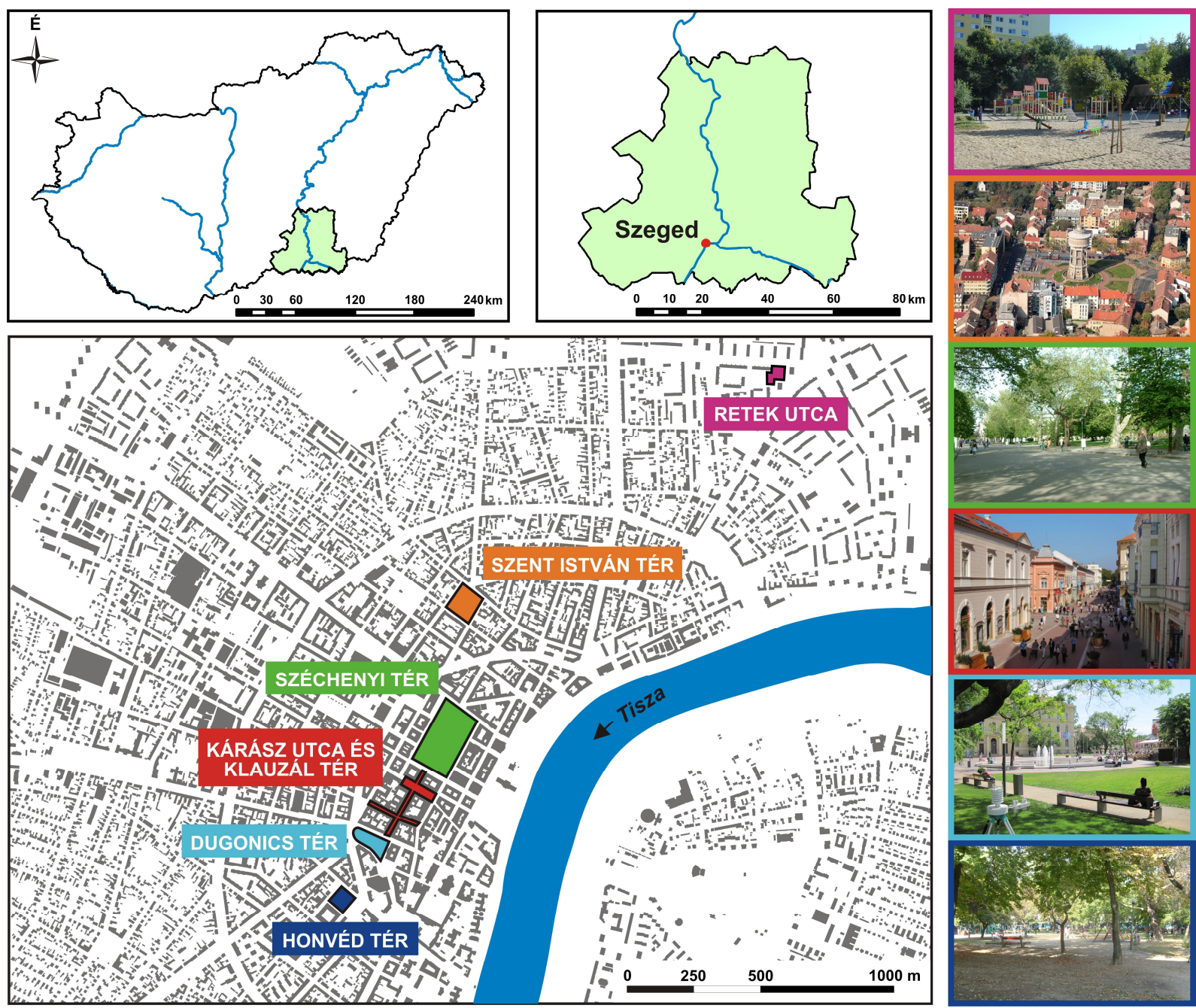

4.2. ábra: A szegedi humánkomfort-felmérés mintaterületeinek elhelyezkedése 
A meteorológiai adatok gyüjtését két könnyen mobilizálható városklíma-állomással végeztük. 2011 tavaszán a Széchenyi és a Dugonics téren egymással párhuzamosan folyt mérés. A két terület viszonylag eltérő felszín- és vegetációborítással rendelkezik: a Széchenyi tér nagy része parkosított, jelentős árnyékoló faállománnyal, míg a Dugonics teret nagyobbrészt mesterséges felszínborítás uralja, árnyékos terület kevesebb található. Ebben az esetben a Széchenyi téren árnyékos helyre helyeztük az egyik állomásunkat, a másikat pedig a Dugonics tér egy napos területére. 2011 nyarától mindkét müszerünket mindig ugyanarra a térre, de annak két különböző pontjára tettük, melyek közül az egyik egy napnak kitett, míg a másik (épület vagy vegetáció által) árnyékolt pont volt. A Szent István téren - árnyék szinte teljes hiányában - mindkét müszer napon, ugyanakkor eltérő felszínborítású területen helyezkedett el (térkövön és füves felszínen) (4.1. táblázat).

4.1. táblázat: A szegedi humánkomfort-felmérés adatgyüjtési módszerei mérések útján

\begin{tabular}{|c|c|c|c|}
\hline $\begin{array}{l}\text { Felmérési } \\
\text { periódus }\end{array}$ & Helyszín & $\begin{array}{l}\text { Mérési } \\
\text { napok }\end{array}$ & $\begin{array}{c}\text { Állomás } \\
\text { elhelyezése }\end{array}$ \\
\hline \multirow{2}{*}{ 2011. tavasz } & Széchenyi tér & 12-12 nap, & \multirow{2}{*}{$\begin{array}{c}\text { 1-1 állomás párhuzamosan } \\
\text { a két téren }\end{array}$} \\
\hline & Dugonics tér & párhuzamosan & \\
\hline 2011. nyár & $\begin{array}{l}\text { Honvéd tér } \\
\text { Retek u. } \\
\text { Kárász u. } \\
\text { Szt. István tér }\end{array}$ & 2-2 nap/terület & \multirow{9}{*}{$\begin{array}{l}\text { 1-1 állomás ugyanazon tér } \\
\text { két eltérő pontján }\end{array}$} \\
\hline \multirow{2}{*}{ 2011. ősz } & Retek u. & 6 nap & \\
\hline & Kárász u. & 5 nap & \\
\hline \multirow{2}{*}{ 2012. tavasz } & Retek u. & 5 nap & \\
\hline & Kárász u. & 5 nap & \\
\hline 2012. nyár & $\begin{array}{l}\text { Honvéd tér } \\
\text { Retek u. } \\
\text { Kárász u. } \\
\text { Széchenyi tér }\end{array}$ & 4-4 nap/terület & \\
\hline \multirow{2}{*}{ 2012. ősz } & Széchenyi tér & 6 nap & \\
\hline & Szt. István tér & 7 nap & \\
\hline $\begin{array}{l}\text { 2015. tavasz } \\
\text { 2015. nyár }\end{array}$ & Dugonics tér & 8 nap & \\
\hline
\end{tabular}

A mérések a három év során minden nap 10:00 és 18:00 óra között zajlottak (néhány esetben a mérést eső miatt korábban meg kellett szakítani), s összesen 78 mérési nap született. A sokrétü vizsgálatsorozatból dolgozatomhoz a mérési és a kérdöíves eredmények szükségesek, így a következőkben az ezekkel kapcsolatos, vizsgálatomhoz szükséges részleteket mutatom be.

\section{A szubjektiv höérzet felmérése}

A kérdőíves felmérést a területeken hosszabb ideje tartózkodó látogatókkal végeztük. Az adatgyüjtés transzverzális kialakítású volt, vagyis nagyszámú személy egyszeri, pillanatnyi értékelésére voltunk kíváncsiak, szemben az ugyancsak elterjedt longitudinális vizsgálatokkal, 
melyekben kevesebb egyén, egy adott időtartam során többször is értékel (de Freitas 1990). A kérdőívek egymástól jól elkülönülő kérdéscsoportok mentén épültek fel, és kitöltésük optimális esetben öt-hat percet vett igénybe. A kérdőívek egyes blokkjaiban feljegyeztük a látogatók személyes jellemzőit (elsősorban azon tényezők felvételezését tartottuk fontosnak, melyek befolyással bírhatnak a termikus környezet értékelésére), felmértük területhasználati szokásaikat és motivációikat, a termikus környezetre vonatkozó szubjektív reakcióikat és értékeléseiket, valamint a térkialakítással kapcsolatos egyéni megítélésüket (Függelék 2. ábra). Dolgozatomban a termikus viszonyokra adott szubjektív reakciókat, és ezen belül is a látogatók hőérzetét vizsgáló blokk adatait használom fel (4.3. ábra).

A szubjektív hőérzet (thermal sensation - TS) rögzítésére a legtöbb termikus komfortot vizsgáló tanulmány 7 fokozatú szemantikus differenciálskálát használ (Függelék 1. táblázat), melyen hidegtől forróig terjednek a választható hőérzetopciók (hőérzetszavazatok) (TSV thermal sensation vote). Ezt a fajta - eredetileg beltéri vizsgálatokhoz kifejlesztett - hőérzeti skálát a szegedi vizsgálatokban 9 fokozatúvá bővítettük, beiktatva egy-egy kategóriát a nagyon hideg és a nagyon forró viszonyok jellemzésére (Kántor 2012, 2016, Kántor et al. 2011a, 2011b, 2012, 2016a, Kovács et al. 2014, 2016) (2.2.4. fejezet). Ennek motivációját egyrészt az képezte, hogy így a kültéren tapasztalható termikus viszonyok szélesebb spektrumát tudjuk lefedni. Másrészt a hagyományos PET-kategóriarendszer is 9 kategóriából áll, az extrém hidegstressz/nagyon hideg hőérzettől az extrém hőstressz/nagyon forró hőérzetig (3.2. ábra, Matzarakis and Mayer 1996, Matzarakis et al. 1999), s így megalapozottabbá válik a későbbiekben az objektív adatok és a szubjektív értékelések közötti kapcsolat vizsgálata. Kilencpontos TSV-skálára Cohen et al. (2013) és Yahia and Johansson (2013) munkájában találunk példát (Függelék 1. táblázat).

Az elemzés megkönnyítése érdekében a kategóriákat -4 és +4 közötti értékekkel dekódoltuk, ahol a -4 jelenti a nagyon hideg, a +4 pedig a nagyon forró hőérzetet (4.3. ábra). A TSVskálánk lehetővé tette a kilenc fő hőérzeti kategória megjelölésén túl a hőérzet tizedesjegy pontosságú megjelölését is (erre mindössze Xi et al. 2012 munkájában láthatunk példát). Tudomásom szerint a magyar vizsgálat az egyetlen, amely kilenc fó kategóriából álló TSVskálát alkalmazott és ezzel együtt köztes tartományok kiválasztását is lehetővé tette. A vizsgált három év során összesen 6764 darab kérdőív született.

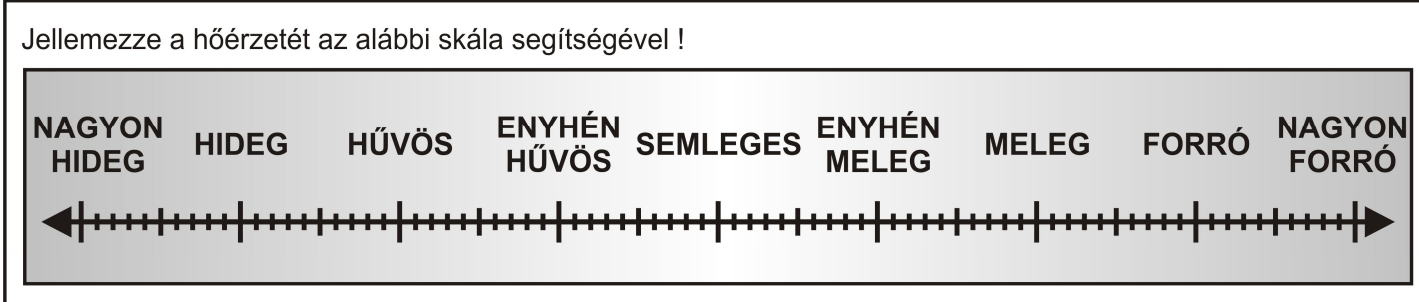

4.3. ábra: A szegedi humánkomfort-felmérés során használt kilenc fő kategóriából álló hőérzeti skála (részlet a kérdőívből)

\section{A mikrometeorológiai paraméterek mérése}

A mikrometeorológiai adatok gyưjitését az említett két mobil városklíma-állomással végeztük (a továbbiakban VK-1 és VK-2 állomás), melyeket speciálisan a humánkomfortfelméréseink céljából állítottak össze (4.4. ábra). Teleszkópos háromlábak segítségével mind- 
két müszeregyüttes 1,1-1,2 m magasságra szintezhető, amely megfelel a városi humánbioklimatológiai vizsgálatokra vonatkozó irányelveknek (VDI 3787), vagyis egy átlagos európai személy súlypont-magasságának (Mayer 2008, Mayer et al. 2008, VDI 1998).

A müszerek a termikus viszonyok értékeléséhez szükséges meteorológiai változók (léghömérséklet, relatív nedvesség, szélsebesség, rövidhullámú és hosszúhullámú sugárzási fluxusok) egyperces átlagértékeit rögzítették. Az állomások két-két fő müszeregyüttesből épülnek fel. A léghőmérséklet, a légnedvesség, valamint a szélsebesség perces értékeit egy-egy Vaisala WXT520 típusú mérőmüszer szolgáltatta (4.4. ábra). A rövid- és hosszúhullámú sugárzási fluxusok mérését egy-egy Kipp \& Zonen gyártmányú CNR 1 (a VK-1 állomáson) és CNR 4 típusú (a VK-2 állomáson) nettó radiométer tette lehetővé, melyek egy-egy, egymásnak háttal elhelyezkedő (vagyis egyszerre két hemiszféra monitorozását lehetővé tevő) piranométerből és pirgeométerböl állnak (4.4. ábra). A szenzorokra vonatkozó adatokat a 4.2. táblázat tartalmazza. A sugárzásmérők egy-egy forgatható karra voltak felszerelve, ami lehetővé tette mind a sugárzásmérő, mind a kar $90^{\circ}$-kal történő elforgatását. Így biztosítva volt, hogy a rövid- és hosszúhullámú sugárzási fluxusokat hat, egymásra merőleges irányból mérjük (felső és alsó hemiszféra, kelet-nyugat és észak-dél). A két $90^{\circ}$-os forgatást hárompercenként, manuálisan végeztük (az érdekesség kedvéért megemlítem, hogy a három év során a két állomáson ez közel $25000 \mathrm{db}$ forgatást jelentett). A szenzorok beállási idejére és a forgatással nyert időveszteségre tekintettel az első egyperces sugárzási fluxus adatokat töröltük adatbázisunkból.

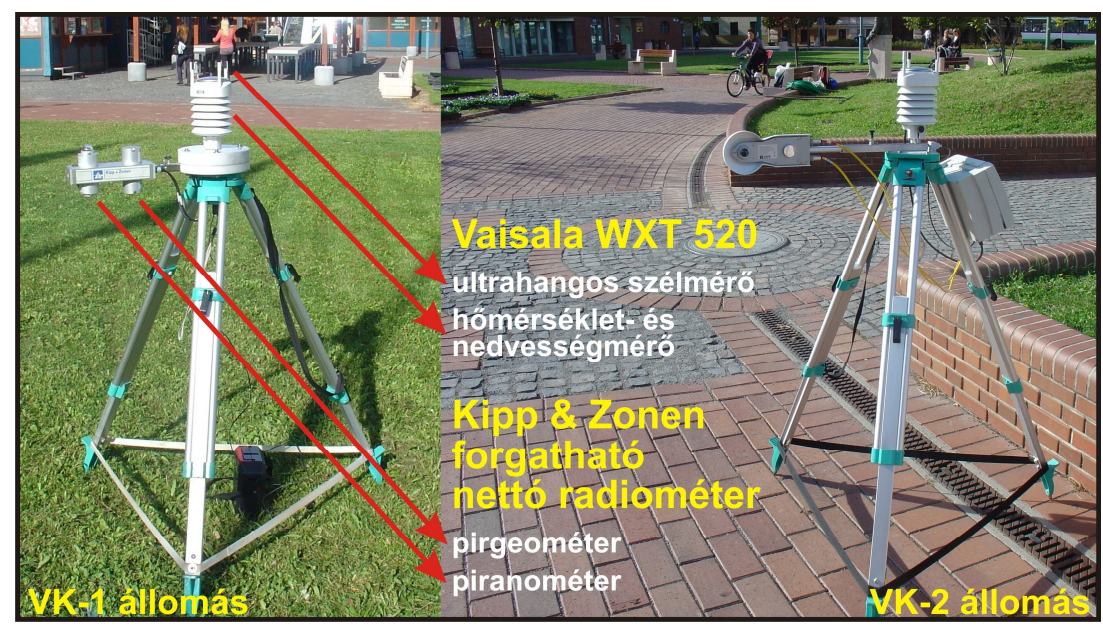

4.4. ábra: A szegedi humánkomfort-felmérés során használt városklíma-állomások (VK-1 és VK-2) és legfontosabb egységeik

4.2. táblázat: A városklíma-állomások szenzorai, pontosságuk és mérési magasságuk

\begin{tabular}{cccc}
\hline Paraméter & Szenzor & Pontosság & Magasság \\
\hline$T_{a}\left[{ }^{\circ} \mathrm{C}\right]$ & Thermocap, WXT 520, Vaisala & $\pm 0,3{ }^{\circ} \mathrm{C} 20{ }^{\circ} \mathrm{C}$-nál, $\pm 0,25{ }^{\circ} \mathrm{C} 0{ }^{\circ} \mathrm{C}$-nál & $1,2 \mathrm{~m}$ \\
\hline$R H[\%]$ & Humicap, WXT 520, Vaisala & $\pm 3 \% 0-90 \%$-nál, $\pm 5 \% 90-100 \%$-nál & $1,2 \mathrm{~m}$ \\
\hline$v[\mathrm{~m} / \mathrm{s}]$ & $\begin{array}{c}\text { Windcap ultraszónikus anemomé- } \\
\text { ter, WXT 520, Vaisala }\end{array}$ & $\pm 3 \%$ vagy $\pm 0,3 \mathrm{~m} / \mathrm{s}$ (nagyobb) & $1,2 \mathrm{~m}$ \\
\hline$K_{i}, L_{i}\left[\mathrm{~W} / \mathrm{m}^{2}\right]$ & $\begin{array}{c}\text { forgatható CNR 1 és CNR 4 nettó } \\
\text { radiométer, Kipp \& Zonen }\end{array}$ & $1,1 \mathrm{~m}$ \\
\hline
\end{tabular}

$T_{a}=$ léghőmérséklet, $R H=$ relatív nedvesség, $v=$ szélsebesség, $K_{i}=$ rövidhullámú sugárzási fluxusok, $L_{i}=$ hosszúhullámú sugárzási fluxusok 
A sugárzásmérők forgatásának az ún. átlagos sugárzási (radiációs) hőmérséklet $\left(\boldsymbol{T}_{\boldsymbol{m} r \boldsymbol{t}}\right)$ számításában volt szerepe, amelyet később a PET számításához kellett felhasználnom. A $T_{m r t}$ mérőszám egyetlen, Celsius-fok dimenziójú számértékben összegzi az emberi szervezetet érő valamennyi rövid- és hosszúhullámú sugárzás höhatását. Definíció szerint annak a képzeletbeli feketetestként sugárzó ( $\varepsilon=1$ emisszivitású) buroknak az egységes hőmérséklete, amely ugyanazt a sugárzási hőcserét eredményezné egy, a hipotetikus környezetben lévő ember számára, mint a valóságos (komplex) sugárzási környezet, amelyben ez a személy valójában tartózkodik (Fanger 1972, Höppe 1992, VDI 1998, ASHRAE 2001, Kántor and Unger 2011). Értéke a gyenge sugárzással jellemezhető zárt terekben nagyjából megegyezik a beltéri környezet léghőmérsékletével, szabadtéren azonban többszörösen meghaladhatja azt (VDI 1998, Kántor and Unger 2011). Mivel a sugárzási tér szabadtéri környezetben (különösen városi környezetben) rendkívül komplex, a $T_{m r t}$ pontos meghatározása az egyik legnehezebb feladat a szabadtéri termikus komfortkutatásokban (Höppe 1992, Spagnolo and de Dear 2003, Kántor et al. 2015).

Mai ismereteink szerint a $T_{m r t}$ meghatározásának legpontosabb módszere a már említett, hat kardinális irányból érkező rövid- és hosszúhullámú sugárzási fluxusok mérését veszi alapul (Höppe 1992). Az eljárás lényege, hogy a hat féltérből érkező sugárzási fluxusokat ún. láthatósági tényezőkkel súlyozza, majd ennek eredőjeként számítja ki a $T_{m r t}$-t:

$$
T_{m r t}=\sqrt[4]{\frac{\sum_{i=1}^{6} W_{i} \times\left(a_{k} \times K_{i}+a_{l} \times L_{i}\right)}{a_{l} \times \sigma}}-273,15 \quad\left[{ }^{\circ} \mathrm{C}\right] .
$$

Az egyenletben $K_{i}$ a rövidhullámú, míg $L_{i}$ a hosszúhullámú sugárzási fluxusok értékét jelöli, $a_{k}$ és $a_{l}$ az emberi test rövid- és hosszúhullámú tartományra vonatkozó abszorpciós képessége (standard értékük 0,7 és 0,97). A $\sigma$ jelöli a Stefan-Boltzmann-állandót, melynek értéke $\sigma$ $=5,67 \times 10^{-8} \mathrm{~W} / \mathrm{m}^{2} \mathrm{~K}^{4} . W_{i}$ a láthatósági súlytényező, melynek értéke a különböző irányoknak kitett testfelszín méretétől függ $\left(\Sigma W_{i}=1\right)$. Megszokott gyakorlat a humán-biometeorológiai kutatások során, hogy $W_{i}$ értékeit egy forgásszimmetrikusnak tekintett álló vagy sétáló emberre adják meg: a négy oldalirány (négy égtáj) esetében 0,22 , míg a két függőleges irányt (az alsó és felső hemiszférát) tekintve 0,06 (Höppe 1992, VDI 1998).

Miután valamennyi mérési adat rendelkezésemre állt (tehát a két VK-állomással mért $T_{a^{-}}$, $R H$-, $v$-, valamint a kiszámolt $T_{m r t}$-adatok), az egyperces értékekböl ötperces mozgóátlagokat számoltam (összhangban a kérdőíves interjúk tipikus időtartamával), s ezeket használtam fel további számításaimhoz.

\section{A mérési és a kérdöíves adatok összekapcsolása}

A 4.1. ábra értelmében a mérések révén előállított objektív adatokat hozzárendeltem a kérdőíves adatbázishoz, hogy reprezentálhassam a megkérdezett személyek aktuális termikus környezetét. Az adatok csatolása az állomások (közterenként és időszakonként eltérő) elhelyezkedésétől (4.1. táblázat), az aktuális égboltviszonyoktól és maguktól a meteorológiai paraméterektől függően rendkívül komplex módon, jól meghatározott módszertan szerint történt. A következőkben a csatolás módszertanának legfontosabb elemeit vázolom (4.3. táblá$z a t)$. 
4.3. táblázat: A mérési és a kérdőíves adatok összekapcsolásának módszertana

\begin{tabular}{|c|c|c|c|c|c|}
\hline \multirow[b]{2}{*}{$\begin{array}{l}\text { Felmérési } \\
\text { periódus }\end{array}$} & \multirow[b]{2}{*}{ Helyszín } & \multirow[b]{2}{*}{$\begin{array}{c}\text { Állomás } \\
\text { elhelyezése }\end{array}$} & \multicolumn{2}{|c|}{$T_{m r t}, T_{a}$ - és $R H$-adatok csatolása } & \multirow[t]{2}{*}{$v$-adatok csatolása } \\
\hline & & & $\begin{array}{c}\text { Napos és árnyékos } \\
\text { térrészek } \\
\text { elkülöníthetők }\end{array}$ & $\begin{array}{l}\text { Napos és árnyékos } \\
\text { térrészek nem } \\
\text { elkülöníthetők, } \\
\text { vagy az egész } \\
\text { terület árnyékban } \\
\text { van }\end{array}$ & \\
\hline \multirow{2}{*}{ 2011. tavasz } & Széchenyi & „árnyékos” VK-1 & $\begin{array}{l}\rightarrow \text { árnyékban lévő } \\
\text { alanyok }\end{array}$ & \multirow{6}{*}{$\begin{array}{c}\rightarrow \text { állomás } \\
\text { közelsége } \\
\text { alapján }\end{array}$} & \multirow{6}{*}{$\begin{array}{c}\longrightarrow \text { állomás } \\
\text { közelsége } \\
\text { alapján }\end{array}$} \\
\hline & Dugonics & „napos” VK-2 & $\begin{array}{l}\rightarrow \text { napon lévő } \\
\text { alanyok }\end{array}$ & & \\
\hline \multirow{4}{*}{$\begin{array}{l}\text { 2011. nyár } \\
\text { 2011. ősz } \\
\text { 2012. tavasz } \\
\text { 2012. nyár } \\
\text { 2012. ősz } \\
\text { 2015. tavasz } \\
\text { 2015. nyár }\end{array}$} & \multirow{2}{*}{$\begin{array}{l}\text { Honvéd } \\
\text { Retek } \\
\text { Kárász } \\
\text { Széchenyi } \\
\text { Dugonics }\end{array}$} & ,árnyékos” VK-1 & $\begin{array}{l}\rightarrow \text { árnyékban lévő } \\
\text { alanyok }\end{array}$ & & \\
\hline & & „napos” VK-2 & $\begin{array}{l}\rightarrow \text { napon lévő } \\
\text { alanyok }\end{array}$ & & \\
\hline & \multirow{2}{*}{ Szt. István } & „füves” VK-1 & $\rightarrow$ állomás & & \\
\hline & & „térköves” VK-2 & közelsége alapján & & \\
\hline
\end{tabular}

VK-1, VK-2 = városklíma-állomások, $T_{m r t}=$ átlagos sugárzási hőmérséklet, $T_{a}=$ léghőmérséklet, $R H=$ relatív nedvesség, $v=$ szélsebesség

A szélsebesség esetén a csatoláskor meghatározó tényező minden esetben az egyének pontos elhelyezkedése volt, amelyet minden alkalommal a területet ábrázoló térképen jelöltünk. Mindig az adott egyénhez közelebb elhelyezkedő VK-állomás szélsebességadatát csatoltam a kérdőíves adatokhoz.

Ahhoz, hogy eldöntsem, hogy melyik méröpont $T_{a^{-}}, R H$ - és $T_{m r t}$-adatát rendeljem az egyes kérdőívekhez, figyelembe vettem az egyes alanyok napfénynek való kitettségét (expozíció), a kérdőíveken ugyanis jelöltük, hogy az adott személy napon, félárnyékban vagy árnyékban helyezkedik-e el (feltéve, hogy lehetőség volt a különböző árnyékviszonyokkal rendelkező területek elkülönítésére). Felhasználtam az interjú idejére jellemző aktuális égboltviszonyadatokat is, hogy elkülönítsem azokat az eseteket, amikor az alanyok napfénynek való kitettsége egyértelműen meghatározható volt (Függelék 2. ábra).

A $T_{a^{-}}, R H$ - és $T_{m r t}$-értékek csatolásával kapcsolatban megemlítem, hogy igyekeztünk mindig valamelyik állomáshoz közel elhelyezkedő, a napfénynek az adott állomással ekvivalens kitettségű személyt megkérdezni, s így ennek az állomásnak az adatát csatolni. Tehát gyakorlatilag ez azt jelentette, hogy 2011 tavaszán a Széchenyi téri árnyékos állomás adatait az azon a téren árnyékban tartózkodó alanyokhoz csatoltam, a Dugonics téri napos állomás adatait pedig az ott megkérdezett napon lévő alanyokhoz. 2011 nyarától pedig az árnyékban lévő személyekhez a tér árnyékos részén elhelyezkedő állomás, a „napos” alanyokhoz pedig a napon lévő állomás $T_{a^{-}}, R H$ - és $T_{m r t}$-adatát csatoltam.

Természetesen azt, hogy folyamatosan napon vagy árnyékban helyezkedjen el a müszer, rendkívül nehéz volt biztosítani a köztér sajátosságai (épületek elhelyezkedése, faállomány sugárzásáteresztő-képességének jellege) és a napmagasság folyamatosan változó (évi és napi) menete miatt. Ennek kiküszöbölése úgy müködött az adatok összekapcsolása során, hogy a problémás esetekben az adott napi $K_{i^{-}}$(rövidhullámú sugárzási komponensek) és $T_{m r t}$-adatok alapján eldöntöttem, hogy a müszer valójában napon vagy árnyékban helyezkedett-e el. Ilyen 
„rendellenes” időszakokban a 2011. tavaszi méréskor természetesen csak az állomás aktuális benapozódásával vagy beárnyékolódásával ekvivalens kitettségü alanyokhoz csatoltam (feltéve egyáltalán, hogy a problémás időszak érintett kérdőívet), az ellentétes kitettségű alanyokhoz nem. 2011 nyarától abban a néhány esetben, ha az árnyékos állomás rövid időre napra került, és ez érintett kérdőívet, a kilengéstől mentes (benapozódás előtti-utáni) adatot csatoltam. Ha az adott terület a késő délutáni órákban árnyékba került (leginkább 2011 és 2012 őszén az alacsony napállás miatt a Kárász utcán, a Retek utcai játszótéren és a Széchenyi téren), és ez az időszak érintett napon elhelyezkedő alanyt, akkor a $T_{a}$, $R H$ - és $T_{m r t}$-értékeket az állomásközelség alapján csatoltam (tehát ahogyan a $v$-adatot).

A Szent István tér esetében pedig - ahol mindkét müszerünket csak napra tudtuk helyezni - minden paraméterre az állomás közelsége döntött. Ezen a téren 2012 öszén a késő délutáni órákban az alacsony napállás miatt már beárnyékolódtak a müszerek, így ekkor már csak az árnyékos alanyokhoz csatoltam, az esetleges napon elhelyezkedő személyekhez nem.

A teljes adatbázisra érvényes az, hogy a félárnyékban lévő személyeket minden esetben árnyékosnak tekintettem, és az árnyékos személyekkel ekvivalens szisztéma szerint történt az adatok csatolása. Borult égboltviszonyok esetében (vagyis azokban a percekben, amikor az alanyok napfénynek való kitettségét nem lehetett megállapítani a felhőzet miatt) mind a négy paramétert az állomásokhoz való közelség alapján csatoltam minden helyszínen és időszakban. Elöfordult néhány eset, hogy a csatolási koncepció szerint szükségem lett volna az alany aktuális expozíciójára, de adathiány miatt ez nem állt rendelkezésre. Természetesen ilyen esetekben nem csatoltam az alanyokhoz meteorológiai adatot.

A termikus környezet $\left(T_{a}, R H, v, T_{m r t}\right)$ emberi szervezetre gyakorolt együttes hatásának kifejezése céljából - s így a termikus terhelés objektív számszerüsítésére - a PET-indexet számoltam ki. Fontos kiemelni, hogy a PET-értékeket az imént ismertetett módszertan alapján csatolt $T_{a}-R H-v-T_{m r t}$ kombinációból számoltam ki, végeredményben tehát minden egyes PETérték az adott alany körüli kis termikus környezetet jellemzi. Azokat az eseteket, amikor nem állt rendelkezésemre expozícióadat vagy valamely mérési adatot nem tudtam csatolni (és így természetesen PET-et sem tudtam számolni), kiszürtem az adatbázisból. Így valamennyi elemzésem bázisát összesen $\mathbf{5 8 0 5}$ darab szubjektív-objektív adatpár képezi. Ezen belül a továbbiakban az objektív adatok közül a mérési adatokból számolt PET-értékekre, a szubjektív adatok közül pedig a -4 és +4 közötti értékekként dekódolt szubjektív hőérzeti adatokra (TSV) volt szükségem.

\section{A PET-index és meghatározási lehetösége}

E fejezet lezárásaként röviden kitérek a PET-index, illetve a kiszámításához használt szoftver bemutatására. A PET-indexet kifejezetten kültéri használat céljából fejlesztették ki, így széles körben alkalmazzák a szabadtéri termikus komfortvizsgálatok során (pl. Matzarakis et al. 1999, Gulyás et al. 2006, Lin 2009, Matzarakis and Endler 2010, Mahmoud 2011, Cheng et al. 2012, Kántor et al. 2012, 2016a, Cohen et al. 2013, Pearlmutter et al. 2014, Kovács and Németh 2012, Kovács et al. 2016). A PET értéke a következőképpen értelmezhető. Tegyük fel, hogy enyhén szeles, magas léghőmérséklettel és alacsony páratartalommal jellemezhető kültéri környezetben tartózkodunk, testünket pedig direkt napsugárzás éri. E paraméterek együttese bizonyos fiziológiai válaszokat vált ki szervezetünkből, hogy az elkerülje a túlhevülést (testfelszínközeli vérereink kitágulnak, verejtéktermelésünk intenzívebbé válik). E reak- 
ciók eredőjeként módosul belső testhőmérsékletünk és bőrhőmérsékletünk (utóbbi esetében természetesen jelentősebb különbségek adódnak különböző környezetekben). Ezután képzeljük el, hogy egy tipikus beltéri környezetben tartózkodunk, amelyben a léghőmérsékleten kívül valamennyi termikus paraméter értékét standardizáljuk: $v=0,1 \mathrm{~m} / \mathrm{s}$ (alig van légmozgás), $e=12 \mathrm{hPa}$ (ami $T_{a}=20^{\circ} \mathrm{C}$ esetén $R H=50 \%$ ) és $T_{m r t}=T_{a}$ (nem éri direkt sugárzás a testet). Keressük azt a léghőmérsékletet $\left(T_{a}\right)$, amely esetén a feltételezett beltéri környezet pontosan olyan fiziológiai reakciókat vált ki belölünk (és ezáltal ugyanarra a belső testhőmérséklet- és bőrhőmérséklet-értékre vezet), mint az aktuális szabadtéri környezet. Az aktuális kültéri környezet PET-értéke e léghőmérsékletként értelmezhetö (Mayer and Höppe 1987, Höppe 1999).

Az értékelés minden esetben egy, a közösséget reprezentáló „átlagos” személyre vonatkozik, aki definíció szerint egy 35 éves, 1,75 m magas, 75 kg-os férfi, aki mérsékelt mozgást végez és könnyü ruházatot visel (Mayer and Höppe 1987, Höppe 1999). (Humánbiometeorológiai mérőszámokkal leírva: alapmetabolizmusa és aktivitása révén $85 \mathrm{~W}+80 \mathrm{~W}$ hőt termel a szervezete, és 0,9 clo hőszigetelésü ruházat fedi a testét.)

A PET-értékeket a RayMan Pro 2.1 (továbbiakban RayMan) sugárzási és bioklímamodell segítségével számoltam ki (Matzarakis et al. 2007, 2010a) (4.5. ábra). A modellt a Német Mérnöki Kamara (Verein Deutscher Ingenieure - VDI) irányelvei (VDI 1994, 1998) alapján fejlesztették ki a Freiburgi Egyetem Meteorológiai Intézetében. Sokrétü felhasználási lehetőségei közül az egyik legfontosabb a termikus komfortindexek meghatározása. (A RayMan jelenlegi verziója a PET mellett másik három komfortindex kiszámítását is támogatja, 4.5. $a ́ b r a)$. Ehhez mindössze a négy termikus alapadat ( $T_{a}, R H, v$ és $\left.T_{m r t}\right)$ egyszerü bemenetére volt szükségem. A modell a PET-indexet - definíciójának megfelelően - minden esetben a már említett standard alanyra számítja. (Megjegyzendő, hogy amennyiben $T_{m r t}$-adat nem áll rendelkezésre, a PET más úton is meghatározható a RayMannel, amelyről a 4.2.1. fejezetben található információ.)

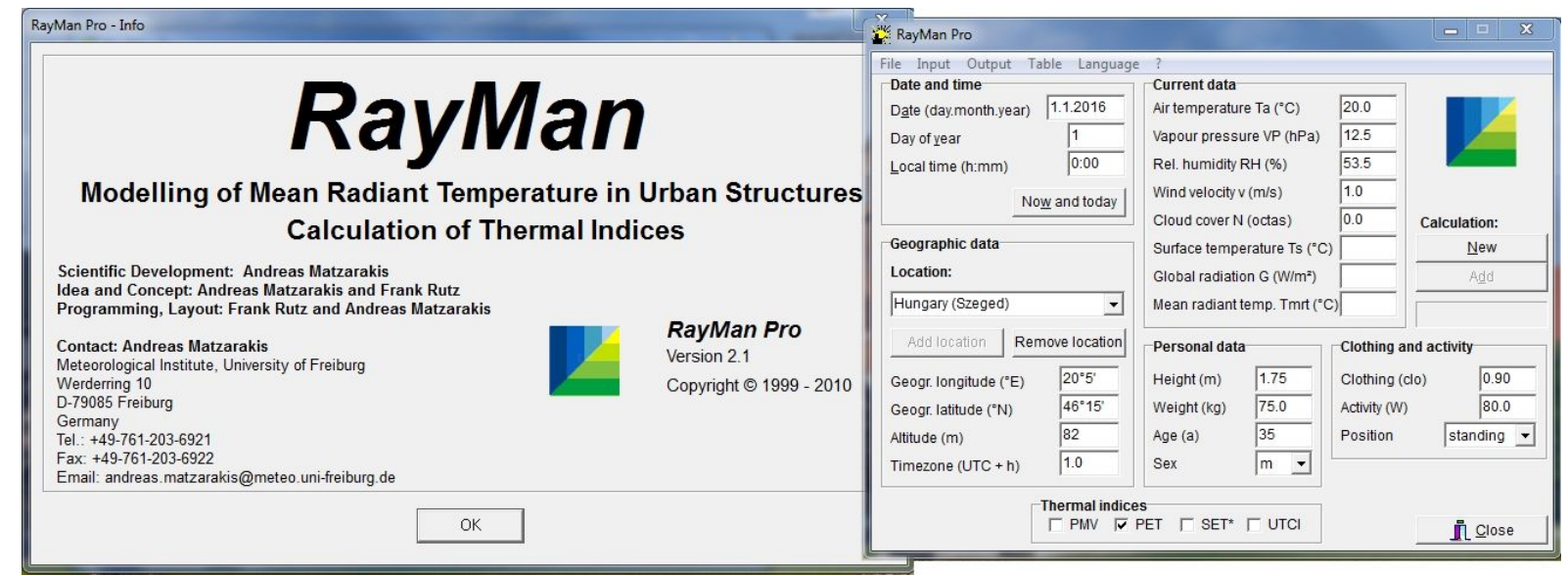

4.5. ábra: A RayMan szoftver nyitóoldala és kezdő munkafelülete

\subsubsection{A turisztikai klímát értékelö eszközök módosítási koncepciói}

\section{A mérési és a kérdöíves adatok közötti kapcsolat meghatározása}

A csatolt objektív (PET) és szubjektív (TSV) adatbázis létrejötte után a következő feladatot a magyar lakosságra jellemző szubjektív hőérzet mintázatának a meghatározása képezte, ami 
gyakorlatilag a két mennyiség közötti kapcsolat vizsgálatát jelenti (4.1. ábra). Valamely szubjektív és objektív termikus adat közötti kapcsolat elemzésére többféle lehetőség nyílik (részletes áttekintés Kántor et al. 2016a munkájában található). Ezek közül a legismertebb és leggyakrabban használt módszer a regressziós technika (Függelék 1. táblázat).

E módszer egyik alapesete, hogy az összes PET-TSV adatpár felhasználásával állítanak fel regressziós kapcsolatot (pl. Krüger and Rossi 2011, Xi et al. 2012, Pearlmutter et al. 2014, Kántor et al. 2016a, Függelék 1. táblázat). Ez esetben azonban nem számíthatunk túl szoros kapcsolatra és magas $\mathrm{R}^{2}$ (determinációs együttható) értékre olyan kiterjedt adatbázisok esetén, mint amilyen a szegedi is, mivel a szubjektív termikus értékelések jelentősen eltérőek lehetnek egyénenként, még azonos (ugyanazzal a komfortindexértékkel jellemzett) termikus viszonyok esetén is. Az egyéni változatosságokból eredö különbségek csökkentése érdekében több szakirodalomban az objektív index kis intervallumaiként (binenként) átlagolják az aktuális TSV-értékeket, s helyettük ezeket az átlagos TSV-értékeket (MTSV - mean thermal sensation vote) állítják párba a komfortindexértékekkel. Így az adatpárok száma a több száz vagy több ezer helyett az alkalmazott binek számával lesz ekvivalens, a grafikus ábrázolás áttekinthetőbbé válik, az $\mathrm{R}^{2}$ értéke pedig szorosabb kapcsolatot jelez. Leginkább az $1{ }^{\circ} \mathrm{C}$-os bin használata terjedt el (pl. Hwang and Lin 2007, Mahmoud 2011, Pantavou et al. 2013, Zeng and Dong 2015), de találhatunk példát $0,5^{\circ} \mathrm{C}$-os (Yang et al. 2013a, 2013b) és $1,2{ }^{\circ} \mathrm{C}$-os intervallum használatára is (Krüger et al. 2013) (Függelék 1. táblázat).

Kántor et al. (2016a) azonban rámutatott, hogy a binenként történő TSV-átlagolás, illetve az MTSV vs. PET regresszió eredményeként jelentősen megváltozhat a regressziós egyenlet, ami később kihat a termikus indexek újraskálázására. Egyszerü átlagolás helyett esetszámmal súlyozott TSV-átlagolást javasolt, ami ötvözi az adott populáció termikus válaszreakcióját hitelesen leíró eredeti TSV vs. PET regresszió és az áttekinthetőbb eredményre és szorosabb kapcsolatra vezető MTSV vs. PET technika előnyeit. Ilyen esetben az illesztett regressziós egyenes egyenlete szinte ugyanaz, mint a súlyozás és binenkénti átlagolás nélküli esetben (az esetek száma ugyanaz a két esetben), de a kapcsolat jóval szorosabbnak adódik. Esetszámmal súlyozott TSV-átlagolást alkalmazott Nakano and Tanabe (2004), Yang et al. (2013a), Kántor (2016) és Kántor et al. (2016a) (Függelék 1. táblázat).

A fenti regressziós technikát használó példák többségében lineáris illesztést alkalmaztak, ugyanakkor néhány irodalomban négyzetes regresszió alkalmazására is találunk példát (Lindner-Cendrowska 2013, Kántor 2016, Kántor et al. 2012, 2016a, Kovács et al. 2014, 2016, 2017). A hazai tanulmányok közül súlyozott hőérzetszavazatokon alapuló regresszióra eddig Kántor (2016), Kántor et al. (2016a) és Kovács et al. (2017) mutatott példát, s a diszszertációmban bemutatandó regressziós eredmények (5.2. fejezet) is e tanulmányokra támaszkodnak. A regresszióanalízist az SPSS Statistics szoftverrel hajtottam végre.

A regressziós módszer révén, a szakirodalomhoz hasonlóan (Függelék 1. táblázat), meghatározható az ún. neutrális hőmérséklet, valamint egyszerüen levezethetők új, a helyi populáció termikus válaszreakcióival összhangban lévő PET-kategóriahatárok (Kántor 2016, Kántor et al. 2012, 2016a, Kovács et al. 2014, 2016, 2017) (4.6. ábra). A neutrális hömérséklet alatt az a (valamely ${ }^{\circ} \mathrm{C}$-dimenziójú mérőszámban kifejezett) hőmérséklet értendő, amelynél az egyének hőérzete semleges, tehát nem fáznak és melegük sincsen. A neutrális hőmérsékletet megkaphatjuk, ha behelyettesítjük az adott TSV vs. PET regressziós függvénykapcsolatba a neutrális höérzetet (vagyis a TSV $=0$ értéket) (4.6. ábra). Az új hőérzeti kategóriahatárok leképezése pedig a TSV $=-3,5,-2,5,-1,5, \ldots,+3,5$ értékek regressziós függvénybe való be- 
helyettesítésével történik. Definíció szerint a neutrális höérzet tartományát a TSV $=[-0,5$; $0,5]$ intervallum jelöli ki, az enyhén meleg kategóriát a TSV $=[0,5 ; 1,5]$, az enyhén hűvös hőérzetet a TSV $=[-1,5 ;-0,5]$ és így tovább (4.6. ábra).

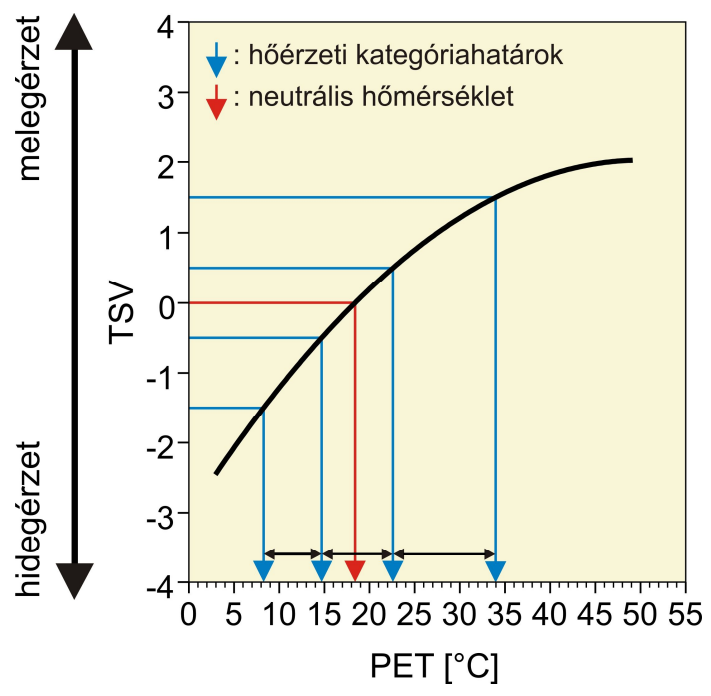

4.6. ábra: A neutrális hőmérséklet és a hőérzeti kategóriahatárok levezetésének elvi alapja regresszió útján (Kovács et al. 2016)

Fontos hangsúlyozni, hogy annak érdekében, hogy a höérzeti mintázatban jelentkező esetleges szezonális különbségeket megvizsgáljam, a regresszióanalízist külön-külön végeztem el minden általam vizsgált évszakra (tavasz, nyár, ösz) (Kántor et al. 2016a, Kovács et al. 2016, 2017). Vizsgálataimban a PET-TSV adatpárok száma a korábban említett összesen 5805 darabból tavasszal 2792, nyáron 1097, míg összel 1916 darab.

A súlyozott, négyzetes, évszakonkénti regressziós függvények, a levezetett évszakos neutrális hőmérsékletek, valamint az évszakos PET-kategóriahatárok alapján részletesen értékelhetők a hazai lakosság hőérzeti sajátosságai (5.2. fejezet). E regressziós függvények képezték az alapját a módosított TCI új termikus al-indexeinek, a levezetett hőérzeti kategóriahatárok pedig a CTIS-hez szükséges új PET-küszöbértékeknek (5.3. fejezet) (4.1. ábra). A következőkben a TCI és a CTIS konkrét módosítási koncepcióját ismertetem.

\section{Értékelő pontok származtatása a TCI-hoz}

A TCI esetében az új termikus értékelő rendszer levezetéséhez - Mieczkowski (1985) alapmódszertanához hasonlóan - 0 (kedvezötlen) és 5 (optimális) közötti értékelő pontokat kellett rendelni a különböző termikus index értékekhez. A következőkben ezen értékelö pontok és a PET közötti kapcsolat levezetésének folyamatát ismertetem, amelyet a 4.7. ábra sematikusan is összefoglal (Kovács et al. 2016).

Mieczkowskitól eltérő módon ez esetben az értékelő pontok hozzárendelése nem önkényesen és nem szakaszosan történt (vö. 2.5.d. és 4.7.b. ábra). Elsöként szükség volt egy új függvénykapcsolatra, amelyben az értékelő pontok a kitüntetett (egész) TSV hőérzetszavazatokhoz vannak hozzárendelve. A párosítást mindkét (a hideg- és melegérzeti) irányban ekvivalens módon végeztem: 0 pont járul a TSV $= \pm 3$ értékhez, 1-es érték a TSV $= \pm 2,5$-hez, 2 a $\mathrm{TSV}= \pm 2$-höz és így tovább. Ahhoz, hogy folytonos értékelő pontsorozatot kapjak, függvényt illesztettem ezekre az egész TSV-értékekre (4.7.a. ábra). Ennek során a lehetséges maximális 
5 pontot (optimális) a neutrális hőérzet $(\mathrm{TSV}=0)$ kapta, míg a 4-es értékelő pont a TSV $= \pm 1$ hez járult. Közöttük másodfokú függvény szerint csökken az adható pont értéke. E TSVtartományon kívül az értékelö pontok lineárisan csökkennek mindkét irányban -1 pont/0,5 TSV meredekséggel. A TSV $= \pm 3$ tartományon kívül 0 (kedvezőtlen) pont járul a TSVértékekhez.

A végső PET-alapú értékelő rendszert (4.7.b. ábra) az előző részben ismertetett TSV vs. PET regressziós függvénykapcsolatot (4.7.c. ábra) az értékelö pont vs. TSV kapcsolatba (4.7.a. ábra) helyettesítve kapjuk. Az így kapott folytonos értékelő pont vs. PET függvény alapján minden egyes PET-értékhez egy-egy 0 és 5 közötti értékelö pont járul, s így a módosított TCI kiszámítható (Kovács et al. 2016). A fenti módszertant mindegyik vizsgált évszakra külön-külön alkalmaztam, a megfelelö évszakos MTSV vs. PET függvénykapcsolat felhasználásával.
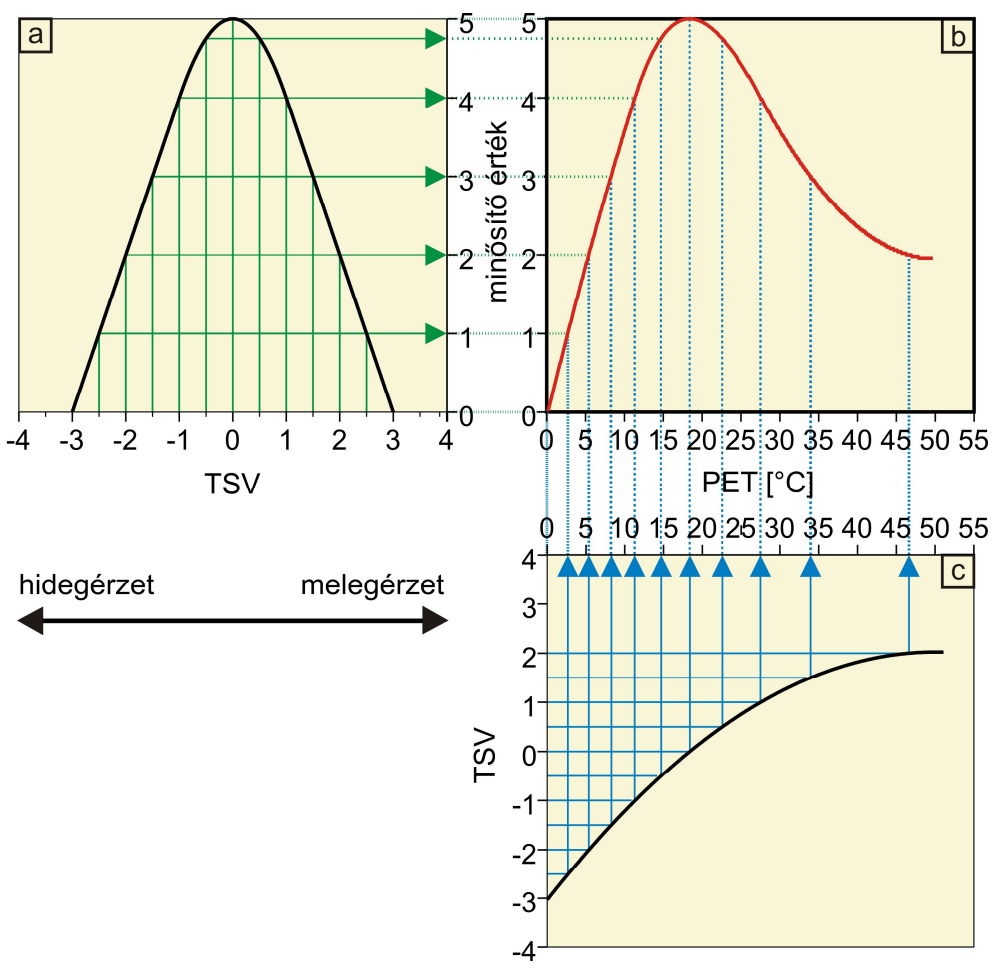

4.7. ábra: A TCI módosításához szükséges PET-alapú értékelő rendszer (b) levezetése sematikusan, felhasználva az értékelő pont vs. TSV (a), illetve a TSV vs. PET (c) függvénykapcsolatokat (Kovács et al. 2016)

A gyakorlati számítások során (4.2. fejezet) a módosított TCI új nappali komfort tagjaként (CId) a napi maximum PET-, a napi komfort tagjaként $(C I a)$ pedig a napi átlagos PETértékeket vettem, s ezeket értékeltem a fenti módszertan szerint levezetett, évszaktól függő értékelö pontokkal. (A dolgozat további részeiben a módosított TCI-t röviden mTCI-nak, míg az eredeti, Mieczkowski-féle változatot TCI-nak nevezem. Az mTCI termikus komponenseire pedig $\boldsymbol{m} \boldsymbol{C I d}$, illetve $\boldsymbol{m} \boldsymbol{C I} \boldsymbol{a}$ jelölésekkel hivatkozom.)

\section{Hőérzeti kategóriák származtatása a CTIS-hez}

A CTIS új PET hőérzeti küszöbértékeinek definiálásához elegendő egyetlen függvénykapcsolat, mégpedig a TSV vs. PET regressziós függvény, mivel annak segítségével levezethetőek hőérzeti kategóriák (4.6. ábra). A $\pm 0,5$ TSV-intervallumhoz tartozó PET-tartomány jelöli 
ki azokat a termikus viszonyokat, amelyeket a magyar lakosok átlagosan neutrálisnak éreznek (4.8. ábra). A CTIS-hez szükséges meleg höérzeti küszöbértéket a meleg PET-kategória kezdetétől vettem, amelyet a TSV $=1,5$ érték jelöl ki. Hasonló szisztémát használtam a hideg höérzeti küszöbérték meghatározásához, vagyis ezt a TSV $=-1,5-h e z$ tartozó PET-érték adta (4.8. ábra) (Kovács et al. 2016). E módszertant jelen esetben is mindegyik vizsgált évszakra külön-külön elvégeztem a megfelelö regressziós függvénykapcsolatból kiindulva.

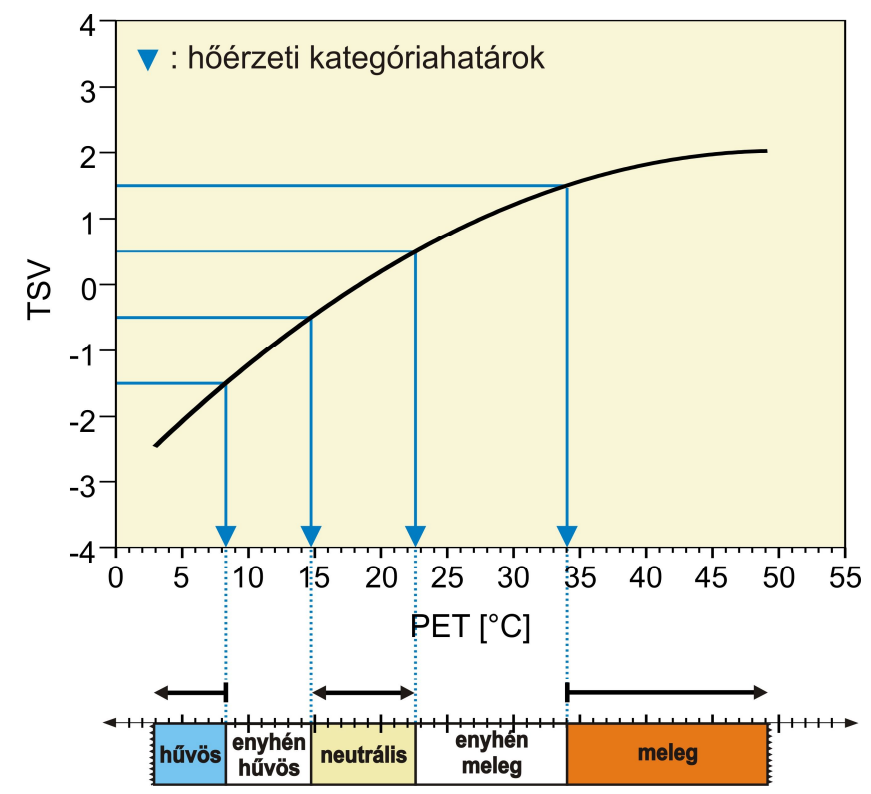

4.8. ábra: A CTIS-hez szükséges, a helyi lakosság hőérzetét tükröző kategóriahatárok (küszöbértékek) levezetésének elvi alapja (Kovács et al. 2016)

\subsection{Az alkalmazási példák adatbázisa és módszertana}

\subsubsection{A turisztikai desztinációk értékelésének adatbázisa és módszertana}

Az első alkalmazási példa során turisztikai desztinációk klímapotenciálját értékelem a TCI, az mTCI és a CTIS alapján (4.1. ábra). A magyar lakosokra adaptált eszközök lehetővé teszik, hogy a különböző területek klímapotenciálját az odautazó, az otthoni klimatikus körülményekhez szokott lakosság szemszögéböl elemezhessük. Vizsgálatomat hat hazai és négy további európai célterület példáján végzem, melyek jól reprezentálják hazánk és Európa változatos éghajlati viszonyait. Az értékelésekhez a területeken elhelyezkedő - a nemzeti meteorológiai szolgálatok által üzemeltetett - meteorológiai állomások mérési adatait használtam fel (4.9. ábra, 4.4. táblázat).

A mérőállomások közös jellemzője, hogy külvárosokban vagy külterületeken helyezkednek el, s füvel borított felszínen, nagy égboltláthatóságú területen találhatók, így megfelelő reprezentációi a regionális háttérklímának. A hazai területekre az OMSZ által rendelkezésemre bocsátott állomási mérési adatokat használtam fel. A külföldi állomások adatait a spanyol fejlesztésű OGIMET adatbázisból, szinoptikus időjárási táviratokból válogattam le (OGIMET 2014), melyek nyers adatok voltak, ezért ellenőriztem és javítottam őket. Elemzéseim négy hazai város esetében az 1996 és 2010 közötti tizenöt év átlagára vonatkoznak, míg két hazai és a külföldi városok esetében a 2000-2010 időszakra álltak rendelkezésre adatok. 

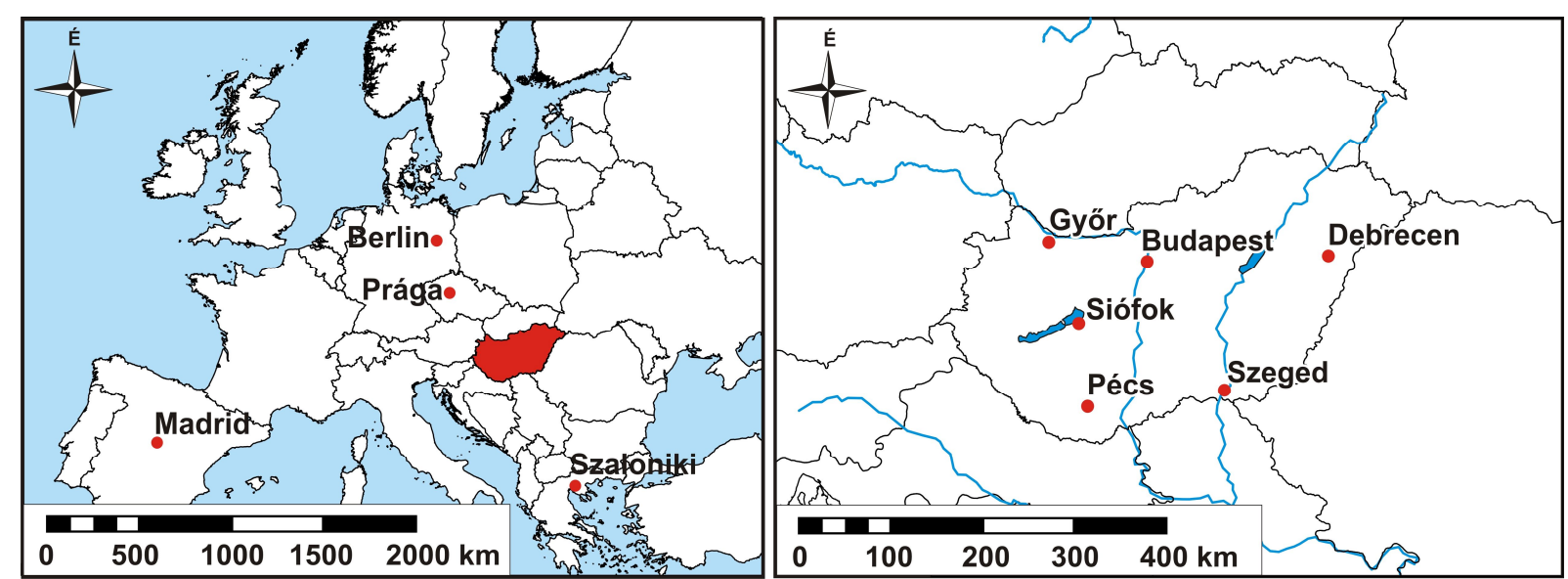

4.9. ábra: A vizsgált turisztikai célterületek elhelyezkedése

4.4. táblázat: A vizsgált területek meteorológiai állomásainak földrajzi adatai

\begin{tabular}{cccc}
\hline Állomás & Szélesség (É) & Hosszúság (K) & Tengerszint feletti magasság (m) \\
\hline Szeged-Bajai út & $46^{\circ} 15^{\prime}$ & $20^{\circ} 05^{\prime}$ & 82,0 \\
\hline $\begin{array}{c}\text { Budapest- } \\
\text { Pestszentlörinc }\end{array}$ & $47^{\circ} 25^{\prime}$ & $19^{\circ} 10^{\prime}$ & 139,1 \\
\hline Debrecen & $47^{\circ} 29^{\prime}$ & $21^{\circ} 36^{\prime}$ & 107,6 \\
\hline Siófok & $46^{\circ} 54^{\prime}$ & $18^{\circ} 02^{\prime}$ & 108,2 \\
\hline Györ-Likócs & $47^{\circ} 42^{\prime}$ & $17^{\circ} 40^{\prime}$ & 116,7 \\
\hline Pécs-Pogány & $45^{\circ} 59^{\prime}$ & $18^{\circ} 14^{\prime}$ & 200,2 \\
\hline Berlin-Tegel & $52^{\circ} 33^{\prime}$ & $13^{\circ} 18^{\prime}$ & 37,0 \\
\hline Prága-Libus & $50^{\circ} 0^{\prime}$ & $14^{\circ} 26^{\prime}$ & 302,0 \\
\hline Szaloniki-repülötér & $40^{\circ} 31^{\prime}$ & $22^{\circ} 58^{\prime}$ & 4,0 \\
\hline Madrid-Barajas & $40^{\circ} 28^{\prime}$ & $3^{\circ} 33^{\prime}$ & 609,0 \\
\hline
\end{tabular}

A TCI-számításhoz órás léghőmérséklet-, relatív nedvesség, szélsebesség-, valamint napi napfénytartam- és napi csapadékösszeg-adatokra volt szükségem. Az mTCI-hoz ezeken felül órás összfelhőzetadatot is felhasználtam, amely a módosított termikus komfort tagokat alkotó PET-értékek kiszámításához kellett. E pontnál meg kell jegyeznem, hogy mivel a meteorológiai állomások nincsenek felszerelve speciális humán-biometeorológiai müszerekkel, a PETértékeket a 4.1.1. fejezetben ismertetett, hatirányú $T_{m r t}$-számítási módszer alapján természetesen nem lehet meghatározni. $T_{m r t}$-adat hiányában ugyanakkor a RayMan modell alkalmas annak modellezésére is, majd a modellezett $T_{m r t}$ felhasználásával a különböző komfortindexek kiszámolására. Ehhez meg kell adni negyedik termikus alapadatnak globálsugárzás- $\left(\mathrm{W} / \mathrm{m}^{2}\right)$ vagy felhőborítottság-adatokat (okta), továbbá a modellezett időre vonatkozó dátumot és időpontot, valamint a földrajzi helyszínnel kapcsolatos paramétereket: földrajzi szélességet, hoszszúságot és tengerszint feletti magasságot. A modell ennek során az adott időpontra és helyszínre szimulálja a rövid- és hosszúhullámú sugárzási fluxusokat és így a $T_{m r t}$-t. Sürün beépített környezetben történő modellezésre háromdimenziós felszínmorfológiai adatbázis (domborzat és tereptárgyak) vagy a modellben halszemoptikás felvételböl megrajzolt horizontkorlátozási poligon használata is célszerü. 
A külföldi meteorológiai állomások esetében a szinoptikus táviratokban a relatív nedvesség nem szerepelt, viszont a rendelkezésre álló léghőmérséklet- és harmatpontadatok alapján egyértelmüen meg tudtam határozni a következö összefüggések szerint (Bartholy et al. 2013):

$$
\begin{gathered}
e_{s}=e_{s}\left(T_{a}\right)=6,11 \times 10^{\frac{a \times T_{a}}{b+T_{a}}} \quad[\mathrm{hPa}] \\
e=e_{s}\left(T_{d}\right)=6,11 \times 10^{\frac{a \times T_{d}}{b+T_{d}}} \quad[\mathrm{hPa}] \\
R H=\frac{e}{e_{s}} \times 100[\%] .
\end{gathered}
$$

Az (5) összefüggés az $e_{s}$ telítési vízgőznyomás kiszámításának gyakorlatban használt formuláját mutatja egy $T_{a}\left({ }^{\circ} \mathrm{C}\right)$ léghőmérsékletü telített levegőre vonatkozóan, ahol $a$ és $b$ állandók értékei vízfelszín felett: $a=7,5$ és $b=237,3{ }^{\circ} \mathrm{C}$, míg jégfelszín felett: $a=9,5$ és $b=265,5$ ${ }^{\circ} \mathrm{C}$ (Tetens-formula, Tetens 1930). A (6) összefüggésben kihasználtam, hogy a $T_{d}$ harmatponthoz tartozó telítési gőznyomás megegyezik az e tényleges gőznyomással. Végül az $R H$ relatív nedvesség értékeit előállítottam a (7) definíció szerint az $e$ és $e_{s}$ hányadosaként.

A TCI-hoz meghatároztam az órás adatokból a napi maximum-hőmérséklet és minimum relatív nedvesség, valamint a napi átlaghőmérséklet és átlagos relatív nedvesség értékeit. Az mTCI-hoz először az órás léghőmérséklet-, relatív nedvesség, szélsebesség- és felhőborítottság-adatokból PET-értékeket számoltam a RayMan modellel. (A modellfuttatáshoz szükségem volt az aktuális dátumokra, időpontokra, valamint a 4.4. táblázatban is feltüntetett állomási földrajzi koordinátákra és tengerszint feletti magasságokra.) A 10 m-en mért állomási szélsebességadatokat még a PET-számítás előtt a humán-bioklimatológiai irányelveknek megfelelően 1,1 m-es magasságra redukáltam. A termikus komfortvizsgálatokkal foglalkozó szakirodalom a következő összefüggést használja a szélsebesség 1,1 m-re történő redukálásához (pl. Spagnolo and de Dear 2003, Gulyás et al. 2006, 2010, Nikolopoulou and Lykoudis 2007, Kántor 2012, Vitt 2012, Fröhlich and Matzarakis 2013, Égerházi 2014, Toy and Kántor 2016):

$$
v_{1,1}=v_{10} \times\left(\frac{1,1}{10}\right)^{\alpha} \quad[\mathrm{m} / \mathrm{s}], \quad \alpha=0,12 \times z_{0}+0,18
$$

Az összefüggésben $v_{10}$ a 10 m magasságban mért szélsebesség, $\alpha$ pedig egy olyan empirikus együttható, mely a felszíni érdességet jellemző $z_{0}$ érdességi paraméter függvénye. A $z_{0^{-}}$ értékek meghatározása az egyes állomásokra a WMO (2012, I.5. fejezet, 13. o.) érdességi paraméter táblázata alapján történt.

Az órás PET-értékek kiszámítása után meghatároztam a napi maximum és átlagos PETértékeket. Az mTCI nappali $(m C I d)$, illetve napi komfortindex $(m C I a)$ tagját e napi maximum PET-, illetve napi átlagos PET-értékek alkották.

A TCI és mTCI-hoz szükséges változókból végül tíznapos átlagokat képeztem (a napi csapadékösszeg esetében tíznapos összegeket), mivel az indexeket az eredeti időbeli felbontásnál finomabb tíznapos bontásban használom (3.1. fejezet, 1. TCI-problémakör). Így az egyes al- 
indexek értékelő ponttal történő ellátását is a tíznapi értékekre alkalmaztam. Ezenfelül a napi értékek (átlagok, maximumok, minimumok) képezésekor az éjjeli órákat kihagytam, mivel a turisztikai aktivitás elhanyagolhatónak tekinthető ebben az időszakban, így véleményem szerint a vizsgálatára nincs szükség. A nappali órákat úgy határoztam meg, hogy kiszámoltam az egyes városok átlagos tíznapos napfelkelte és napnyugta időpontjait, s a kettő közé eső egész órákat (órás adatokat) tekintettem nappaliaknak, így ezeket vontam be a számításokba.

A TCI meghatározása az időbeli felbontást kivéve teljes mértékben megegyezett $M i$ eczkowski (1985) módszerével (2.5. ábra). Az mTCI termikus tagjainak ( $m$ CId, $m C I a$ ) értékelése pedig a 4.1.2. fejezetben ismertetett módszertan szerint levezetett, a magyar lakosokra vonatkozó, évszakosan változó értékelő pontokkal történt. A napfénytartam és a szélsebesség al-index $(S, W)$ értékelő rendszereit, valamint valamennyi al-index súlyértékét változatlanul hagytam, Mieczkowski értékelő rendszerének megfelelően (2.2. táblázat, 2.5. ábra). További fontos kiegészítő információ, hogy mivel a csapadék tag $(\boldsymbol{R})$ értékelő pontrendszere is eredetileg havi adatokra (havi csapadékösszegre) vonatkozott, a tíznapi összegek értékeléséhez hárommal leosztottam az eredeti csapadékösszeg kategóriahatárokat (2.5. ábra), és ezeket értékeltem az eredeti, Mieczkowski-féle pontértékekkel.

A CTIS esetében a termikus komponensek értékelését az eredeti és a hazai lakosságra vonatkozó évszakos PET-küszöbértékek alapján is bemutatom (módszertan: 4.1.2. fejezet). A fizikai és az esztétikai komponensek esetében az eredeti küszöbértékeket használtam a gyakorisági eloszlás meghatározásához (2.5. táblázat). A CTIS-értékelést is tíznapos felbontásban alkalmazom, s ez esetben is kizárólag a nappali időszakra vonatkozó órás adatokat használtam fel a gyakoriságok számításához. Az eredményeket a CTIS 1.1b szoftver segítségével jelenítettem meg (Matzarakis 2007, Matzarakis et al. 2010c).

\subsubsection{A turisztikai klímapotenciál-változás vizsgálatához használt adatbázis és módszertan}

Ebben a fejezetben a második alkalmazási példához szükséges módszertani ismereteket és adatbázist mutatom be (4.1. ábra) (Kovács et al. 2017). A turisztikai klímapotenciál jövőbeli változásának értékeléséhez a TCI és az mTCI mutatókat használtam. Az indexeket elsőként a jelen klímát jellemző referencia-időszakra (1961-1990) számoltam ki az OMSZ által létrehozott mérési adatbázis felhasználásával. Az adatbázis a 3.3.1. fejezetben ismertetett, $10 \mathrm{~km}$-es felbontású CarpatClim-adatokon alapult (melyet Hódos 2014 is használt). A CarpatClim projektterületét az OMSZ a későbbiekben kiterjesztette Magyarország teljes területére, lefedve a $45,8-48,6^{\circ} \mathrm{E}$ és $16-27^{\circ} \mathrm{K}$ rácsot, ezáltal az ország egész területére lehetővé vált a klímapotenciál értékelése. E $10 \mathrm{~km}$-es felbontású adatbázis 1104 rácspontot jelentett az ország területén (4.10. ábra). A rácsponti adatok előállítása a CarpatClim projektben is alkalmazott MASH és MISH homogenizációs és interpolációs eljárásokkal történt (3.3.1 fejezet).

A relatív nedvesség napi minimumértékei nem álltak rendelkezésre a mérési adatbázisban, így azokat egy délnyugat-angliai éghajlati esettanulmányban alkalmazott becslési módszerrel határozta meg az OMSZ (Whittlesea and Amelung 2010). A becslés egyrészt kihasználja, hogy a (7) egyenlet értelmében a relatív nedvesség napi minimális értéke fordítottan arányos a napi maximum-hőmérséklethez tartozó telítési gőznyomással, s az utóbbi pedig meghatározható a (5) Tetens-formula alapján a maximum-hőmérséklet behelyettesítésével. A (7) egyenlet $e$ tényleges gőznyomás tagjának meghatározásához pedig feltételezi, hogy az $e$ a nap folyamán állandó, így a napi átlagos relatív nedvességből és a napi átlaghőmérséklethez tartozó 
telítési gőznyomásból (ami a Tetens-formulából a napi átlaghőmérsékletet behelyettesítve kiszámolható) a (7) összefüggés átrendezett alakjával meghatározható. A napi minimum relatív nedvesség kiszámolásához szükséges összes mennyiség szerepelt a mérési adatbázisban.

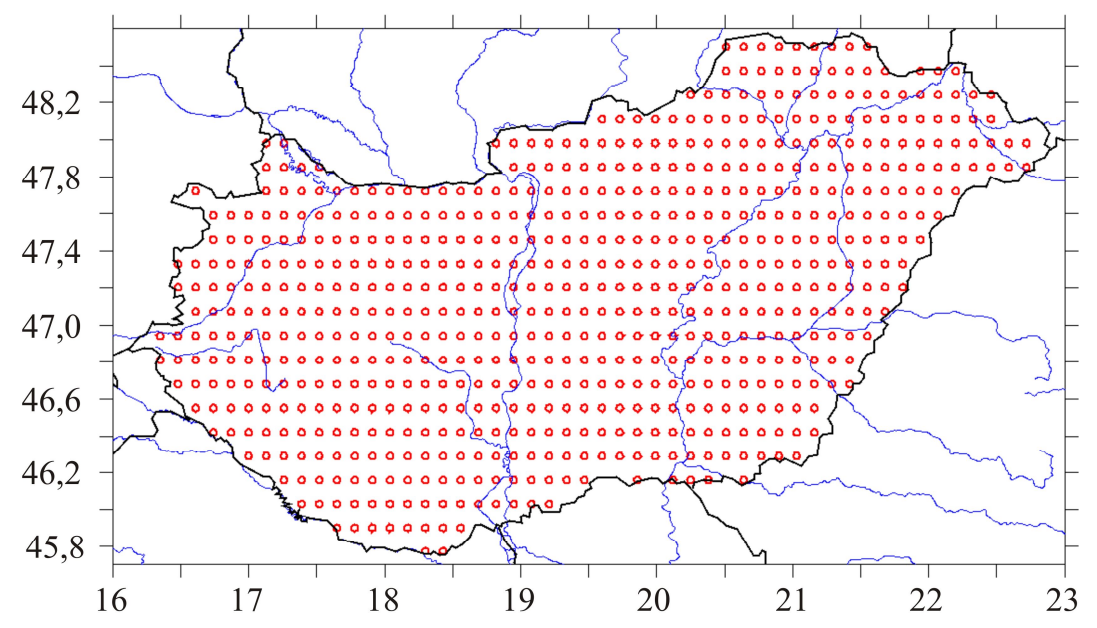

4.10. ábra: A homogenizált, interpolált mérési adatbázis és az ALADIN-Climate modell $0,1^{\circ} \times 0,1^{\circ}$ felbontású rácshálózata (Sábitz et al. 2015)

A jövőbeli becslésre vonatkozó meteorológiai adatokat az OMSZ-ban korábban futtatott ALADIN-Climate 4.5 regionális klímamodell szolgáltatta. A modellel egy a Kárpátmedencét ugyancsak az említett $10 \mathrm{~km}$-es rácsfelbontással lefedő tartományra készültek éghajlat-változási szimulációk (Csima and Horányi 2008). A modellkísérlet során az emberi tevékenység jövőbeli alakulására az IPCC SRES (Special Report on Emissions Scenarios, Nakicenovic et al. 2000) forgatókönyv-családjából a közepes A1B kibocsátási szcenáriót alkalmazták. A forgatókönyv az antropogén szennyezőanyag- és üvegházgáz-kibocsátásra a 21. század közepéig növekvő, majd a század végéig csökkenő tendenciával, s a század végére 700 ppm-et meghaladó szén-dioxid-koncentrációval számol. A Kárpát-medence tartományán kívül zajló folyamatok leírását (azaz az oldalsó határfeltételeket) az ARPEGE-Climat globális klímamodell szolgáltatta.

A modellkísérletek az 1951-2100 közötti időszakra készültek, melyből a következő évtizedekre való tervezéshez szükséges 2021-2050, illetve a hosszabb távú stratégiaalkotáshoz szükséges 2071-2100 időszakra vonatkozó eredményeket használtam fel. A változások meghatározásához szükséges modellreferenciaként - a mérési adatokhoz hasonlóan - az 19611990 időszak szolgált.

A jövőre vonatkozó projekciók kiértékelésekor figyelembe kell venni, hogy a regionális (és globális) modelleredmények szükségszerúen kisebb-nagyobb hibával terheltek, emiatt eliminálni kell a jövőre és a múltra vonatkozó szisztematikus modellhibákat (Szépszó 2014). E hibák kiszürésére több módszer is elterjedt, melyek közül az ún. delta-módszert használtam (Hawkins et al. 2013). Ez azt jelenti, hogy a jövőbeli modelleredményeket nem önmagukban értelmezzük, hanem a változásértékek megadása révén a modell saját referencia-időszakához viszonyítunk. Meghatároztam tehát a TCI- és mTCI-indexek jövőbeli (2021-2050 és 20712100) értékei és a modellreferencia időszakára (1961-1990) vonatkozó értékei közötti különbségeket, és e változásértékeket hozzáadtam a mérési eredményekhez (1961-1990). Fontos hangsúlyozni, hogy a delta-módszert nem a nyers mérési és modelladatokra alkalmaztam, 
hanem az éghajlatváltozásnak való kitettséget jellemző, származtatott eredményekre (azaz a kiszámolt TCI- és mTCI-adatokra). Így a végeredmény a múltbeli „kitettség-méréseket” és a kitettségben jelentkező változást ötvözi (4.11. ábra).

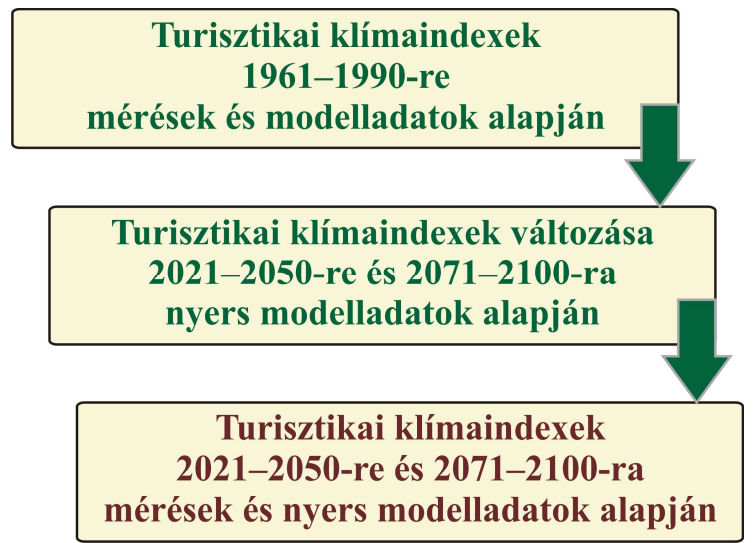

4.11. ábra: A turisztikai klímaindexek meghatározásának lépései a mérési és a modelladatok alapján (Kovács et al. 2017)

Klímamodell-eredmények a napfénytartamra vonatkozóan nem álltak rendelkezésre, ugyanakkor a TCI és mTCI kiszámításához ez az adat is szükséges. A napfénytartamadatokat az Amelung (2006) munkájában részletesen ismertetett módszertan alapján határoztam meg, a felhőborítottság-adatokból kiindulva. Az eljárást az előbbin kívül más tanulmányok is alkalmazták a TCI klímamodelladatokból történő kiszámolására (Perch-Nielsen et al. 2010, Mailly et al. 2014). A módszer a csillagászatilag lehetséges napi napfénytartamhoz viszonyítja a nap napfénnyel jellemzett (százalékban kifejezett) időtartamát, amit a felhőzet (ugyancsak százalékban kifejezett) mennyisége csökkent. A lehetséges napfénytartam pedig meghatározható a napciklus, földrajzi helyszín és időpont figyelembevételével csillagászati összefüggések szerint (Amelung 2006). Mivel a számoláshoz minden szükséges adat rendelkezésemre állt, a fenti módszerrel valamennyi rácspontra és napra meg tudtam határozni a napfénytartam értékét.

A TCI és mTCI kiszámításához a mérési és a klímamodell-eredményekből napi és havi bontású adatok álltak rendelkezésre. A TCI meghatározásához a szükséges mennyiségek havi értékeit használtam fel, s a számítási metódus (értékelő pontrendszerek és formula) teljes mértékben megegyezett Mieczkowski módszertanával (2.3.1. fejezet). Az mTCI kiszámolásához (legalább) napi értékek kellenek a haviak helyett, mivel az mTCI napi maximum és napi átlagos PET-eket igényel. A PET-számítás jelen esetben is a RayMan modellel történt. A számoláshoz a szükséges szélsebességen és felhőborítottságon kívül az $m C I d$ taghoz - ami a napi maximum PET-en alapul - a napi maximum-hőmérsékletet és minimum relatív nedvességet használtam fel, míg az $m C I a$ taghoz - ami a napi átlagos PET-et igényli - a napi átlaghőmérsékletet és átlagos relatív nedvességet. Miután kiszámoltam a PET-értékeket, valamennyi napi értékből (napi maximum PET, napi átlagos PET, szélsebesség, csapadékösszeg és napfénytartam) havi átlagokat képeztem, majd kiszámoltam a havi mTCI-értékeket. A PET-ek értékelése az mTCI-ban természetesen a magyar lakosokra adaptált, évszakosan változó értékelö pontok figyelembevételével történt (módszertan: 4.1.2. fejezet). (Megjegyzendő, hogy a TCI- és az mTCI-indexek havi bontású használata közös megegyezés eredménye: a KRITéR 
projekt keretei és távlati céljai (7.3. fejezet) ennél kisebb felbontást nem engedtek meg, de a turisztikai klímapotenciál értékeléséhez még egy elfogadható időtartamról van szó.)

Miután a havi turisztikai indexeket előállítottam, alkalmaztam rájuk az említett deltamódszert. Végeredményben Magyarország valamennyi rácspontjára (4.10. ábra) rendelkezésemre álltak a TCI- és mTCI-értékek a két jövőbeli időszakra és minden hónapra (kivéve természetesen télre az mTCI esetében). Végezetül a felhasználhatóságot szem elött tartva ArcGIS 10.4. szoftver segítségével járási átlagokat állítottam elő a rácsponti adatokból, s az indexek térbeli eloszlását térképes formában megjelenítettem (Kovács et al. 2017). 


\section{Módszertani fejlesztéshez kapcsolódó eredmények}

\subsection{Az interjúalanyok jellemzői és a humán-biometeorológiai háttérkörülmények}

Az 5.1. táblázat az 5805 darab kérdőíves interjú idejére vonatkozó meteorológiai és humán-biometeorológiai háttérkörülmények legfontosabb statisztikai jellemzőit foglalja öszsze. A felvételezett tavaszi, nyári és őszi időszakok során 7 és $38^{\circ} \mathrm{C}$ közötti $T_{a}$-értékeket mértünk (minimum és maximum). PET-értékekben kifejezve a látogatók ennél jóval szélesebb hőmérséklet-tartományt tapasztalhattak, ugyanis $4-54{ }^{\circ} \mathrm{C}$-os tartományt fedtek le. A tág spektrum még inkább igaz a $T_{m r t}$ eloszlására, amely 3 és $71{ }^{\circ} \mathrm{C}$ között alakult. Az interjúk 50\%-a 17-29 ${ }^{\circ} \mathrm{C}$-os PET-tartományba esett (25-ös és 75-ös percentilis), s a legtöbb interjú 28 ${ }^{\circ} \mathrm{C}$ körüli PET-értékek esetében zajlott (módusz). A PET-értékek eloszlása platikurtikus, vagyis lapult (negatív csúcsosságérték), és kissé jobb oldalra nyúlik el (kevéssel 0 feletti ferdeségi együttható). Hasonló jellemzők mondhatók el az interjúk $T_{a^{-}}$és $T_{m r t}$-eloszlására is. A hőmérséklet-dimenziójú mutatók közül a $T_{m r t}$ rendelkezik a legnagyobb, míg a $T_{a}$ a legkisebb szórással. A relatív nedvesség mennyiségéröl elmondható, hogy igen tág határok között változott (15 és $82 \%$ ), ugyanakkor az interjúalanyok 50\%-a hasonló nedvességi viszonyokat tapasztalt (30 és 46\% között). Ennek megfelelöen az $e$ terjedelme is hasonlóan nagy $(2,2-20,6$ hPa), míg az interkvartilis tartomány szük (7,6-12,5 hPa). A kérdöívek háromnegyede közel szélcsendes vagy gyengén szeles viszonyok között készült $(<1,5 \mathrm{~m} / \mathrm{s})$. A szélsebességadatok eloszlása leptokurtikus, vagyis csúcsos, és erőteljesen jobb oldalra nyúlik el (5.1. táblázat).

5.1. táblázat: A kérdőíves interjúk alatt uralkodó mikrometeorológiai és mikro-biometerológiai háttérkörülmények statisztikai jellemzői (Kántor et al. 2016a)

\begin{tabular}{lcccccc}
\hline & $\boldsymbol{v}(\mathbf{m} / \mathbf{s})$ & $\boldsymbol{e}(\mathbf{h P a})$ & $\boldsymbol{R H}(\mathbf{\%})$ & $\boldsymbol{T}_{\boldsymbol{a}}\left({ }^{\circ} \mathbf{C}\right)$ & $\boldsymbol{T}_{\boldsymbol{m r t}}\left({ }^{\circ} \mathbf{C}\right)$ & $\mathbf{P E T}\left({ }^{\circ} \mathbf{C}\right)$ \\
\hline Átlag & 1,2 & 10,2 & 39,7 & 21,4 & 33,2 & 23,1 \\
\hline Medián & 1,1 & 10,5 & 37,5 & 21,1 & 30,5 & 22,9 \\
\hline Módusz & 0,8 & 11,4 & 28,6 & 13,3 & 31,0 & 27,8 \\
\hline Minimum & 0,1 & 2,2 & 14,8 & 6,9 & 2,7 & 3,6 \\
\hline Maximum & 4,2 & 20,6 & 82,1 & 38,0 & 70,9 & 53,9 \\
\hline 25-ös percentilis & 0,8 & 7,6 & 30,3 & 16,1 & 23,4 & 17,1 \\
\hline 75-ös percentilis & 1,5 & 12,5 & 46,1 & 26,0 & 42,8 & 29,0 \\
\hline Szórás & 0,543 & 3,479 & 12,589 & 6,282 & 13,349 & 8,436 \\
\hline Ferdeség & 0,812 & 0,006 & 0,889 & 0,215 & 0,482 & 0,210 \\
\hline Ferdeség standard hibája & 0,032 & 0,032 & 0,032 & 0,032 & 0,032 & 0,032 \\
\hline Csúcsosság & 0,852 & $-0,458$ & 0,530 & $-0,698$ & $-0,635$ & $-0,291$ \\
\hline Csúcsosság standard hibája & 0,064 & 0,064 & 0,064 & 0,064 & 0,064 & 0,064 \\
\hline$v=$ szélsebesség, $e=$ vízgóznyomás, $R H=$ relatív nedvesség, & $T_{a}=1$ léghömérséklet, $T_{m r t}=$ átlagos sugárzási hö- \\
mérséklet, PET = fiziológiailag ekvivalens hőmérséklet & & & &
\end{tabular}

A megkérdezett interjúalanyok 65\%-a nőnemü volt. Az életkoruk 5 és 95 év között változott, és 59\%-uk a fiatal korosztályhoz tartozott (14-30 év). Többségük jó egészségi állapotnak örvend, és $77 \%$-uk pihenni érkezett a területre, amit az is tükröz, hogy $70 \%$-uk ülő testhelyze- 
tet foglalt el. Az interjúalanyok 63\%-a célzottan az adott térre érkezett, és a terület felkeresésének fő oka másokkal való találkozás (40\%), órák közötti vagy munkahelyi szünet eltöltése (23\%) vagy éppen a jó idő (22\%) volt. A megkérdezettek $82 \%$-a állította, hogy legalább hetente egyszer meglátogatja a területet.

A felmérés során az alanyok leggyakrabban az enyhén meleg (1) hőérzeti kategóriát jelö1ték meg, ezt követték a meleg (2), enyhén hüvös (-1) és a semleges (0) értékelések (5.2. táblázat). Az extrém szavazatok ( -4 vagy 4$)$ előfordulása meglehetősen ritka volt. A megkérdezett személyek több mint 20\%-a választott közbülső szavazatértékeket; ez az arány mindössze $10 \%$ volt a neutrális szavazatcsoport esetében, míg a pozitív extrém höérzetszavazatok esetében csaknem elérte az 50\%-ot (5.2. táblázat). A leggyakrabban választott tizedes értékek két egész érték között éppen félúton voltak (pl. 2,5 vagy 1,5).

5.2. táblázat: A hőérzetszavazatok (TSV) eloszlása, jelölve az adott csoporthoz tartozó egész és köztes szavazatok relatív gyakoriságát (Kántor et al. 2016a)

\begin{tabular}{lcccc}
\hline Höérzet & TSV & Alanyok száma & $\begin{array}{c}\text { Fö kategóriák } \\
\text { gyakorisága (\%) }\end{array}$ & $\begin{array}{c}\text { Köztes kategóriák } \\
\text { gyakorisága (\%) }\end{array}$ \\
\hline Nagyon forró & 4 & 63 & 52 & 48 \\
\hline Forró & 3 & 347 & 51 & 49 \\
\hline Meleg & 2 & 1390 & 73 & 27 \\
\hline Enyhén meleg & 1 & 1708 & 82 & 18 \\
\hline Semleges & 0 & 849 & 90 & 10 \\
\hline Enyhén hüvös & -1 & 942 & 80 & 20 \\
\hline Hüvös & -2 & 388 & 74 & 24 \\
\hline Hideg & -3 & 101 & 76 & 35 \\
\hline Nagyon hideg & -4 & 17 & 65 & 22 \\
\hline Összesen & & 5805 & 78 & \\
\hline
\end{tabular}

\subsection{A magyar lakosság hőérzeti mintázata}

E fejezetben a hazai lakosok hőérzeti mintázatának sajátosságait mutatom be a 4.1.2. fejezetben ismertetett módszerekre épülve. A súlyozott átlagos hőérzetszavazatok (MTSV) és a PET-értékek közötti lineáris és négyzetes regressziós függvénykapcsolatokat az 5.1. ábra szemlélteti. A kapcsolatok feltárása a három vizsgált évszak szerint külön-külön történt ( $N=$ 2792 tavasszal, 1097 nyáron és 1916 ősszel). A lineáris és a négyzetes regresszió is szignifikánsnak bizonyult $(p=0,000)$ mindegyik évszakban. A négyzetes modell alkalmazása mérsékelten növeli a kapcsolat erősségét (nagyobb $\mathrm{R}^{2}$-et eredményez) mindhárom évszakban, mint a lineáris regresszió. A legnagyobb $\mathrm{R}^{2}$-értékek tavasszal és ősszel mutatkoznak $(0,96)$, de a nyári érték is alig kisebb $(0,94)$.

A regressziós görbék meredeksége az alanyok egységnyi PET-változásra eső „termikus érzékenységét" tükrözi. Az eredményül kapott másodfokú egyenletek tanúsága szerint a magyar lakosok hőérzete általában intenzívebben változik a PET-skála hűvösebb viszonyokat jelző végén, s ez a mintázat mindegyik évszak esetén megfigyelhető. Ezzel szemben a melegebb tartományban (magasabb PET-értékek esetén) a megkérdezettek hőérzete csupán enyhén 
emelkedik, ami arra utal, hogy alanyaink a höséggel (melegebb termikus viszonyokkal) szemben toleránsabbak, mint a hideg termikus viszonyokkal kapcsolatban.
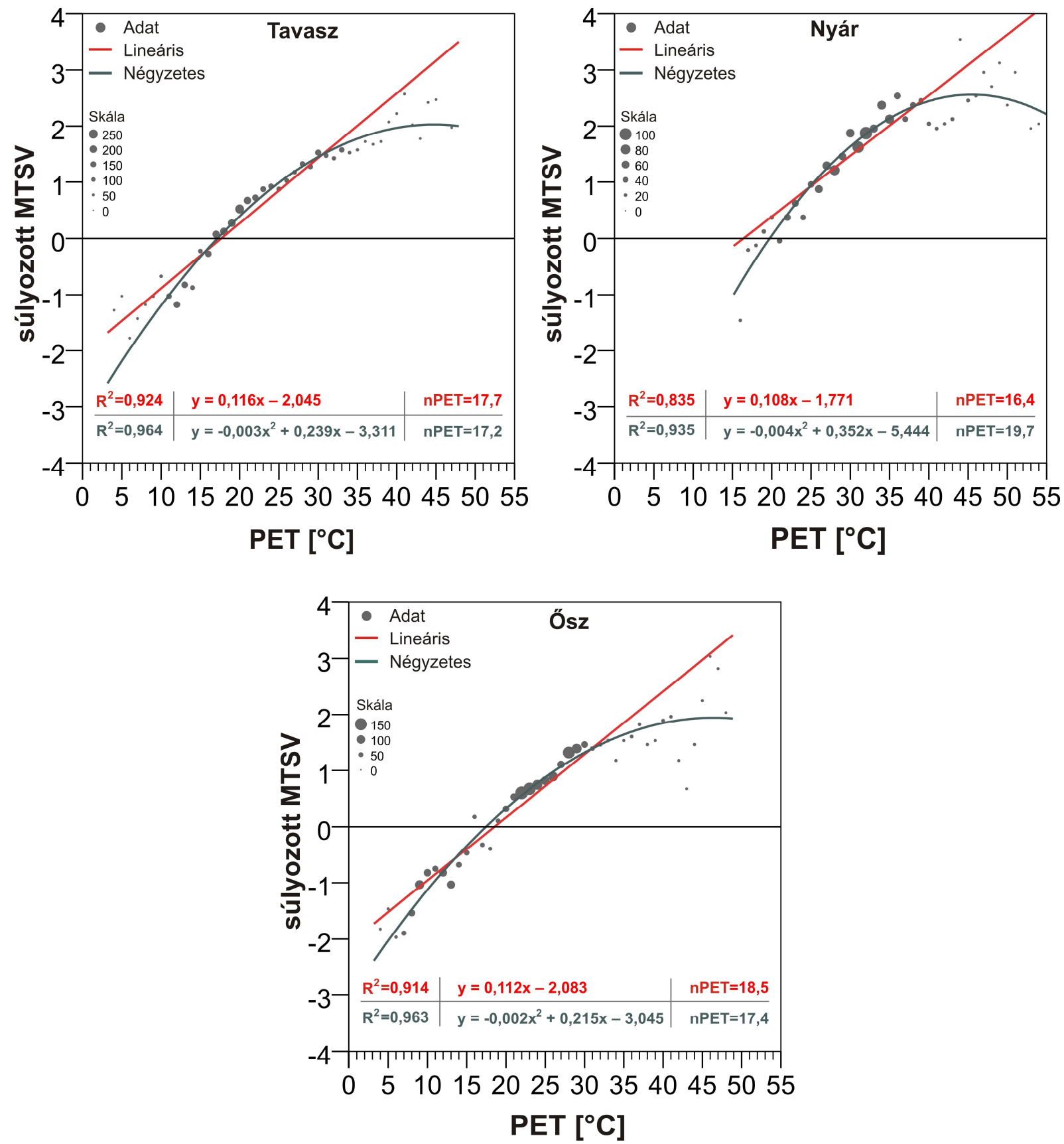

5.1. ábra: A magyar lakosság súlyozott átlagos höérzetszavazatai (MTSV) és a PET közötti regressziós függvények tavasszal $(N=2792)$, nyáron $(N=1097)$ és összel $(N=1916)$, valamint a kapott neutrális hőmérsékletek

(nPET, $\left.{ }^{\circ} \mathrm{C}\right)(p=0,000)$ (Kántor et al. 2016a, Kovács et al. 2016, 2017)

Amennyiben a regressziós egyenleteket TSV $=0$-ra megoldjuk, megkapjuk a neutrális PET hőmérsékleteket (nPET). A négyzetes regresszió eltérő nPET-eket eredményez a lineárishoz képest, s a legnagyobb különbség nyáron tapasztalható (19,7 és $\left.16,4{ }^{\circ} \mathrm{C}\right)$. A négyzetes regresszió esetében csaknem ugyanakkora nPET-ek jelennek meg tavasszal és ősszel $(17,2$ és $\left.17,4{ }^{\circ} \mathrm{C}\right)$, míg jóval nagyobb értéket találhatunk nyáron $\left(19,7^{\circ} \mathrm{C}\right)$. Ugyanakkor a lineáris regresszió esetében a tavasz és az ösz jobban különbözik, és magasabb nPET-et ad (17,7 és 18,5 $\left.{ }^{\circ} \mathrm{C}\right)$, míg a nyári nPET a legalacsonyabb $\left(16,4{ }^{\circ} \mathrm{C}\right)$. 
Mivel a négyzetes illeszkedés szorosabb kapcsolatot jelez, a következökben ezeket a függvénykapcsolatokat vizsgálom és használom fel további elemzéseimhez. A négyzetes regresszió esetében kapott évszakos neutrális hőmérsékleti trend (tavasz, ősz, nyár) összhangban van a hazai szezonális trenddel kapcsolatos elvárásainkkal. A szezonális különbségek változatos adaptációs mechanizmusok következményei, melyek magukba foglalják egyrészt a fiziológiai akklimatizációt a melegebb/hidegebb hőmérsékletekhez, másrészt olyan viselkedési reakciókat, mint például az évszaknak megfelelő öltözet, valamint a mentális felkészülés (korábbi tapasztalatokban gyökerező elvárások) az évszakosan eltérő viszonyokra (Kántor et al. 2016a, Kovács et al. 2016) (3.2. fejezet).

A regressziós technika alkalmas arra, hogy az nPET-hez hasonló módon új hőérzeti értéktartományokat vezessünk le (4.6. ábra). A magyar lakosokra vonatkozó évszakos PETtartományokat és a hagyományos PET fiziológiai stressz tartományokat az 5.2. ábra szemlélteti, amelyeket ugyancsak a súlyozott négyzetes regressziós egyenletekből vezettem le (5.1. ábra).

Tavasszal és ősszel a hazai hőérzeti zónák a hűvöstől a melegig terjednek, nyáron pedig az enyhén hűvöstől a forróig. A regressziós görbék meredekségéből (vagyis az alanyoknak a különböző termikus viszonyokra való eltérő érzékenységéből) adódóan mindegyik évszakban megfigyelhető, hogy alacsonyabb PET-értékeknél keskenyebb, míg magasabbaknál szélesebb hőérzeti zónák adódnak. A kategóriák között eltolódások tapasztalhatók az évszakoktól függően. A neutrális tartomány nyáron magasabb értékeknél található $\left(17,3-22,4{ }^{\circ} \mathrm{C}\right)$, mint tavasszal $\left(14,0-20,8^{\circ} \mathrm{C}\right)$, ami a szezonális termikus adaptációs folyamatokkal magyarázható. A nyári neutrális tartomány a legszűkebb, míg az őszi fedi le a legszélesebb területet (13,9-21,4 ${ }^{\circ} \mathrm{C}$ ): körülbelül ott kezdődik, mint a tavaszi, de annál némileg magasabb értékeket is még neutrálisnak éreznek a magyar emberek.

Megemlítendő, hogy különösen tavasszal és ősszel a neutrális zónák (és természetesen a neutrális hőmérsékletek is) alacsonyabb PET-értékeknél találhatók, mint a hagyományos kategóriarendszer szerint, ahol a $18-23{ }^{\circ} \mathrm{C}$ közötti tartomány felel meg a stresszmentes körülményeknek (Matzarakis and Mayer 1996, Matzarakis et al. 1999). Ezenfelül a szélesebb hazai neutrális intervallumok (úgyszintén elsősorban tavasszal és ősszel) alacsonyabb termikus érzékenységről tesznek tanúbizonyságot, vagyis nagyobb toleranciát jeleznek a szabadtéri termikus körülmények megváltozásával szemben (5.2. ábra). E megállapítás összhangban van például Nikolopoulou and Steemers (2003), Thorsson et al. (2004) és Nikolopoulou and Lykoudis (2006) tanulmányaiban közöltekkel.

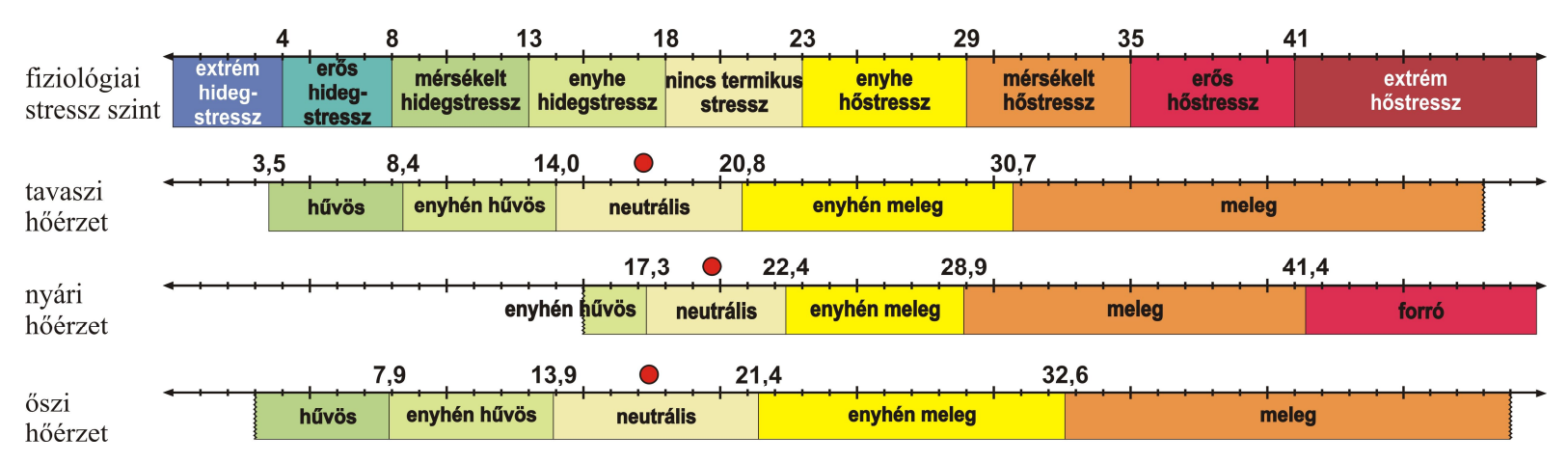

5.2. ábra: A nyugat- és közép-európaiakra vonatkozó PET fiziológiai stressz kategóriák $\left({ }^{\circ} \mathrm{C}\right)($ Matzarakis and Mayer 1996, Matzarakis et al. 1999) és a magyar lakosságra vonatkozó PET-hőérzettartományok $\left({ }^{\circ} \mathrm{C}\right)$ tavasszal, nyáron és ősszel (a piros körök a neutrális hőmérsékleteket jelzik) (Kántor et al. 2016a, Kovács et al. 2016) 
Összefoglalásként elmondható, hogy a magyar emberek hőérzeti mintázatában az eredeti, általánosan használt értéktartományokhoz képest különbségek mutatkoznak (5.2. ábra). Emellett eltérések jelentkeznek az egyes évszakok között is (5.1-2. ábra). Az 5.1. ábrán látható évszakos MTSV vs. PET négyzetes regressziós összefüggések adják az egyik függvénykapcsolatot, amely az mTCI új PET értékelő pontjainak levezetéséhez szükséges (4.7. ábra). Az 5.2. ábrán látható PET-értéktartományokból pedig kialakíthatók a CTIS termikus komponenseinek hazai lakosokra adaptált küszöbértékei (4.8. ábra).

\subsection{A hazai lakossághoz adaptált turisztikai klímát értékelő eszközök}

Az mTCI alapját képező értékelő pont vs. PET közötti évszakos függvénykapcsolatokat az 5.3. ábra mutatja be, amin feltüntettem a neutrális PET hömérsékleteket is, melyek a levezetés értelmében a maximális (5) értékelő pontot kapták. Minden más PET-értékhez pedig egy $[0 ; 5]$ intervallumba eső értékelő pont járult.
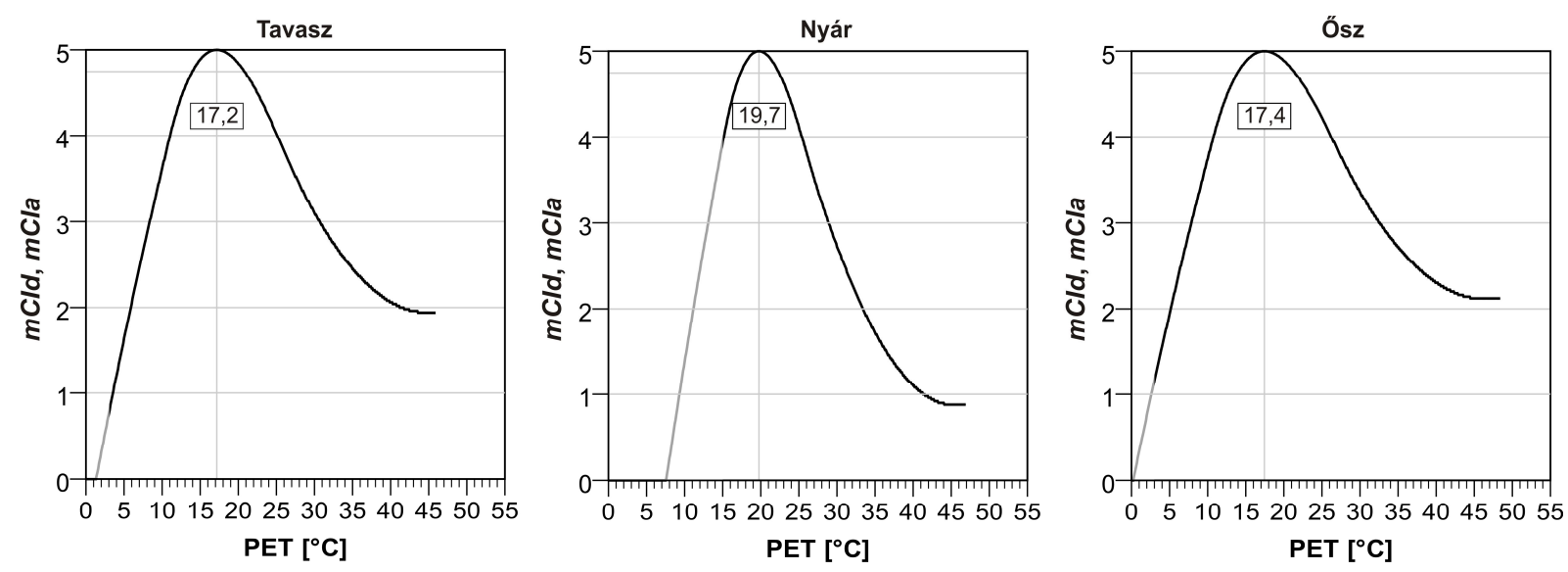

5.3. ábra: Az mTCI termikus al-indexeihez ( $m C I d$ és $m C I a)$ szükséges PET értékelő pontok a különböző évszakokban a magyar lakosság hőérzetszavazatai alapján [azon PET-tartományok esetében, melyek nem álltak fenn a humánkomfort-felmérés idején, a görbeszakasz halványított; a függőleges segédvonal a neutrális PET hőmérsékleteket $\left({ }^{\circ} \mathrm{C}\right)$ jelöli ki] (Kovács et al. 2016, 2017)

Az ábráról leolvasható, hogy mindhárom évszakban a növekvő PET-értékekkel párhuzamosan az értékelö pontok intenzívebben növekednek a hidegebb termikus viszonyok esetében, mint ahogy csökkennek a melegebb körülmények során. Ez az aszimmetria annak a következménye, hogy az MTSV vs. PET regressziós függvényeknek egyre kisebb a meredeksége a magasabb PET-értékek felé haladva (5.1. ábra). Mivel az értékelő pontok a regressziós függvényekből származnak, az ott megjelenő évszakos különbségek átöröklődnek az értékelő pont vs. PET függvénykapcsolatokra is. Így megmutatkozik például az, hogy magasabb PETértékek esetében (kb. $26^{\circ} \mathrm{C}$ felett) kisebb értékelő pontok adódnak nyáron, mint a többi évszakban ugyanolyan PET-érték esetében, ami az eltérő szezonális percepció következménye (5.1-2. ábra).

A CTIS termikus komponenseiben használt magyar PET hőérzeti küszöbértékeket az 5.3. táblázat foglalja össze, évszakos bontásban. A PET-értéktartományok a CTIS-ben mint neutrális, meleg-forró („legalább meleg”), valamint hüvös-hideg („legalább hűvös”) küszöbértékek jelennek meg, és a 4.1.2. fejezetben ismertetett módszertan szerint vezettem le az 5.2. ábrán látható PET-skálákból kiindulva. Az 5.3. táblázat a megfelelö termofiziológiai stressz 
szinteket is mutatja, amelyek természetesen minden évszakban ekvivalensek. A soron következő alkalmazási példákban a CTIS ezen eredeti termikus komponenseit is megjelenítem és összehasonlítom a hazai tartományokkal. A fizikai és az esztétikai komponensek küszöbértékeit változatlannak hagytam, vagyis a 2.5. táblázatban közölt értékeket használtam fel a gyakorisági eloszlások vizsgálatához.

5.3. táblázat: A hagyományos fiziológiai stressz küszöbértékek (Matzarakis and Mayer 1996, Matzarakis et al. 1999), valamint az éghajlat termikus tényezőjének évszakosan eltérő értékelése a magyar lakosság szubjektív értékelése alapján (Kántor et al. 2016a, Kovács et al. 2016)

\begin{tabular}{|c|c|c|c|c|}
\hline \multirow{2}{*}{ Típus } & \multirow{2}{*}{$\begin{array}{c}\text { Kategória- } \\
\text { név }\end{array}$} & \multicolumn{3}{|c|}{ Küszöbértékek } \\
\hline & & Tavasz & Nyár & Ősz \\
\hline \multirow{3}{*}{$\begin{array}{l}\text { Szervezetet } \\
\text { érő } \\
\text { termikus } \\
\text { stressz }\end{array}$} & Stresszmentes & & $18^{\circ} \mathrm{C}<\mathrm{PET}<23^{\circ} \mathrm{C}$ & \\
\hline & Hőstressz & & $\mathrm{PET}>35^{\circ} \mathrm{C}$ & \\
\hline & Hidegstressz & & $\mathrm{PET}<8^{\circ} \mathrm{C}$ & \\
\hline \multirow{3}{*}{$\begin{array}{l}\text { Magyar } \\
\text { lakosság } \\
\text { hőérzeti } \\
\text { mintázata }\end{array}$} & Neutrális & $14{ }^{\circ} \mathrm{C}<\mathrm{PET}<20,8^{\circ} \mathrm{C}$ & $17,3^{\circ} \mathrm{C}<\mathrm{PET}<22,4^{\circ} \mathrm{C}$ & $13,9^{\circ} \mathrm{C}<\mathrm{PET}<21,4^{\circ} \mathrm{C}$ \\
\hline & Meleg-forró & $\mathrm{PET}>30,7^{\circ} \mathrm{C}$ & $\mathrm{PET}>28,9^{\circ} \mathrm{C}$ & $\mathrm{PET}>32,6^{\circ} \mathrm{C}$ \\
\hline & Hüvös-hideg & $\mathrm{PET}<8,4^{\circ} \mathrm{C}$ & $\mathrm{PET}<13,1^{\circ} \mathrm{C}^{\mathrm{a}}$ & $\mathrm{PET}<7,9^{\circ} \mathrm{C}$ \\
\hline
\end{tabular}

a extrapolált eredmény 


\section{Alkalmazási példák}

\subsection{Turisztikai desztinációk értékelése}

\subsubsection{Turisztikai klíma index és módosított Turisztikai klíma index}

Első példaként hat magyar és négy külföldi célterület jelenlegi turisztikai klímapotenciálját értékelem a TCI és az mTCI alapján. Az eredmények a nappali időszak adatain alapulnak (4.2.1. fejezet).

$\underline{\text { Szeged klímapotenciáljának elemzése }}$

A TCI és az mTCI tíznapi értékeinek évi menetét a 6.1. ábra szemlélteti Szegedre vonatkozóan az 1996-2010-es időszak átlagára (a TCI esetében egész évre, az mTCI esetében pedig márciustól novemberig). A TCI évi eloszlása egy nyári csúcshoz hasonlatos szerkezetet jelez (2.7. ábra), de a nyári időszakon belül jelentős különbségek nem mutatkoznak. A legkedvezőbb körülmények májustól szeptemberig találhatók 80-90 körüli értékekkel, ami kitünő körülményeket jelez (2.3. táblázat). Július utolsó dekádjában egy mérsékelt visszaesés látható (TCI $=76$, nagyon jó körülmény). Télen a TCI-értékek 50 alá csökkennek, ami semleges vagy kedvezőtlen viszonyokat jelent. A kedvezőtlenebb téli viszonyok után a tavasz közepén intenzív javulás figyelhető meg, majd a kedvező nyári időszak után az ősz közepén gyors ütemben hanyatlanak a körülmények (6.1. ábra).

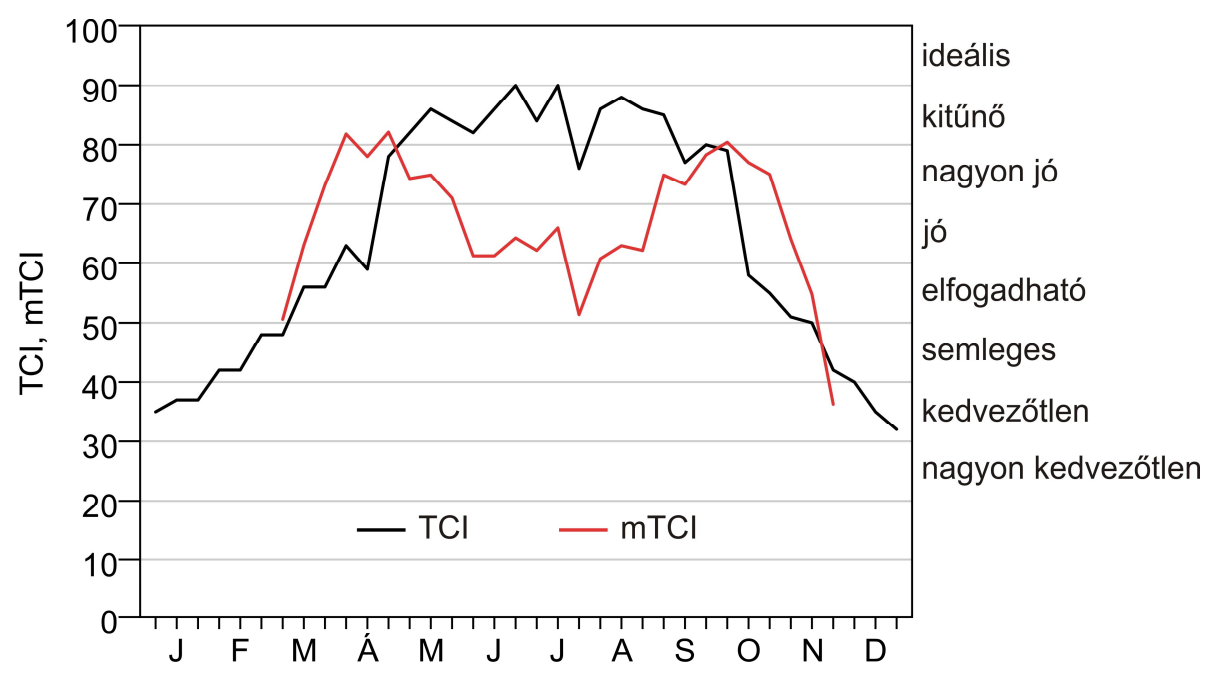

6.1. ábra: A TCI és az mTCI évi menete Szegeden tíznapos felbontásban (1996-2010)

Az mTCI évi menete jelentősen eltér a TCI-éhoz képest. Ez esetben egy erőteljes bimodális szerkezet tünik fel (2.7. ábra), vagyis a legoptimálisabb klíma szabadtéri turizmus szempontjából tavasszal, illetve ősszel jelentkezik, nyáron ugyanakkor kedvezőtlenebb körülmények mutatkoznak. A tavasz és az ősz több, elsősorban középső dekádjaiban nagyon jó (mTCI $\geq 70)$, esetenként kitünő viszonyok uralkodnak (mTCI $\geq 80)$. Április végéig, illetve október elejétől az mTCI kedvezőbb viszonyokat jelez, mint a TCI. Nyáron ugyanakkor határozott visszaesés jelentkezik, ám ki kell emelni, hogy még ekkor is jónak minősülnek a klimatikus körülmények a kevéssel 60 feletti értékekkel. Július utolsó harmadában a módosított index 
esetében is megtalálható egy nagyobb mértékü csökkenés (mTCI $=51$, elfogadható körülmény) (6.1. ábra).

Annak érdekében, hogy tisztában legyünk a TCI és az mTCI eltérö évi menetének lehetséges okaival, fontosnak tartom bemutatni, hogy milyen mértékben járulnak hozzá a TCI/mTCI-t felépítő egyes al-indexek az indexek összértékéhez, tehát a fenti általános sajátosságok kialakításához. A 6.2. ábra mutatja az al-indexekhez tartozó pontértékek évi menetét ugyancsak Szegeden, melyen nemcsak az egyes időszakok közötti különbségek láthatók, hanem a termikus al-indexek szeparációja révén ( $C I d$ vs. $m C I d$, CIa vs. $m C I a$ ) megállapíthatók a két index közötti különbségek okai is.

\section{Szeged}
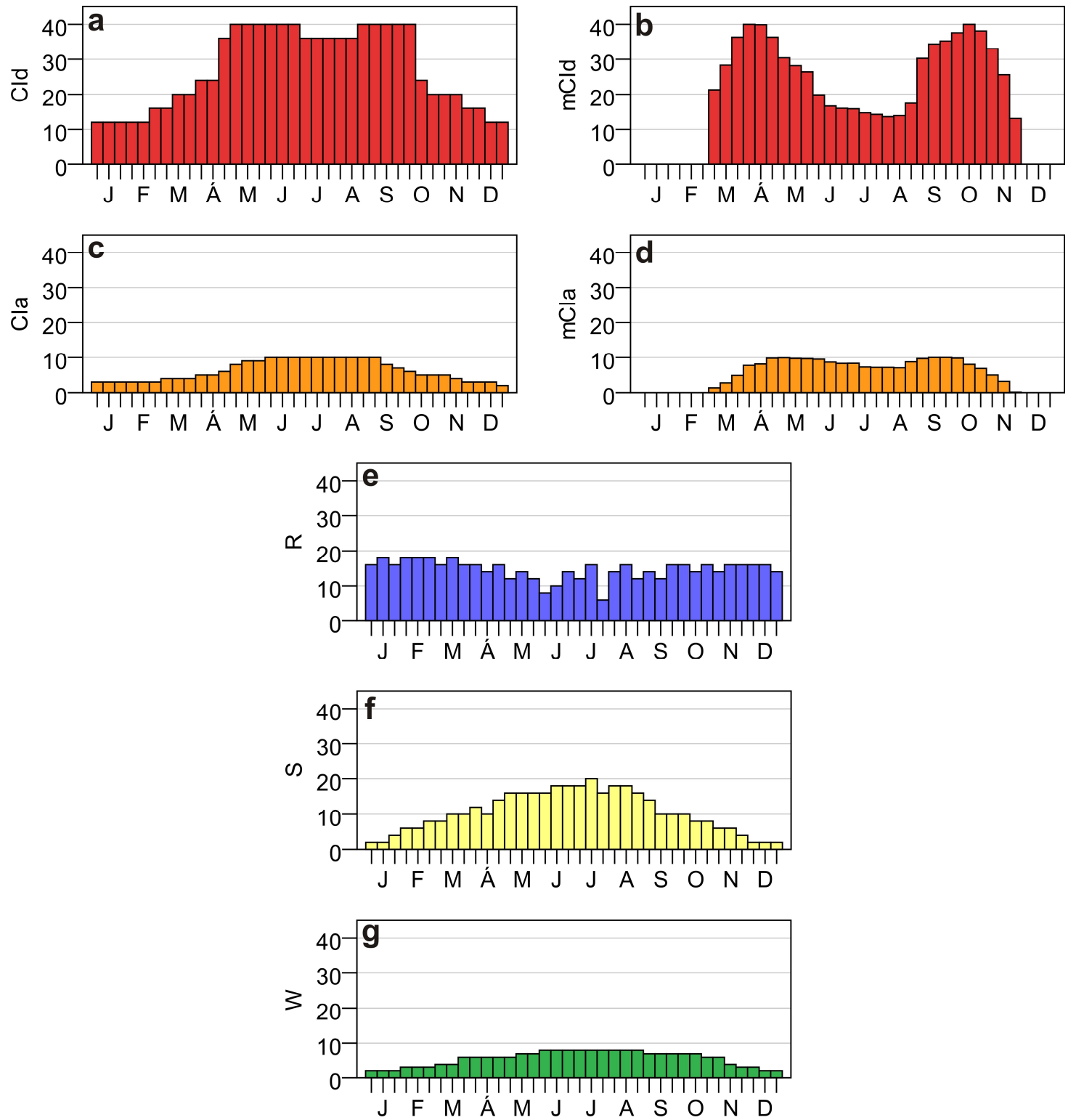

6.2. ábra: A TCI-t és az mTCI-t felépítő al-indexek évi menete Szegeden tíznapos felbontásban (1996-2010). Az egyes al-indexek pontértékelése: $C I d$ - „nappali” maximum-hőmérséklet és minimum relatív nedvesség, $C I a-$ „nappali” átlaghőmérséklet és átlagos relatív nedvesség, $m C I d$ - „nappali” maximum PET, $m C I a-$, ,nappali” átlagos PET, $R$ - tíznapi csapadékösszeg, $S$ - napi napfénytartam, $W$ - ,nappali” átlagos szélsebesség alapján. Az $R, S$ és $W$ al-indexek értékelése a TCI és az mTCI esetében azonos, és megegyezik Mieczkowski (1985) módszerével, annyi különbséggel, hogy a tíznapi értékelés miatt az eredeti $R$-küszöbértékek osztva vannak hárommal 
A 6.2.a-b. ábra alapján világosan megmutatkozik, hogy elsősorban a $C I d / m C I d$ tag a fö felelőse a TCI és az mTCI különböző évi menetének. Ugyanis a nyári időszakban a délutáni órákban, amikor általában magas PET-értékek uralkodnak, a „nappali” maximum PET-en alapuló $m C I d$ tag jelentősen csökkenti az adható pontértéket az átmeneti évszakokhoz képest (5.3. ábra). A különbségek mértékéhez nagymértékben hozzájárul az is, hogy a CId/mCId alindex jelentős súlyt képvisel az indexekben (2.2. táblázat). Az is szembetünő, hogy a nyár néhány dekádjában már a TCI esetében is megjelenik egy kismértékü CId-értékbeli csökkenés.

A nyári csúcs és a bimodális alakzat kialakításában a CIa/mCIa tag is szereppel bír, noha ennek hatása csekély a $C I d / m C I d$-hez képest (6.2.c-d. ábra). A csapadék tagról $(R)$ elmondható, hogy május és augusztus között sokszor kisebb mértékben járul hozzá a TCI/mTCI értékéhez, mint a többi időszakban, mivel ekkor gyakran nagyobb csapadékmennyiség detektálható a tíznapos összegek tekintetében, ami Mieczkowski (1985) értékelö rendszere szerint rontja a turisztikai klimatikus viszonyokat (2.5. ábra). Így tehát a bimodális alakú mTCImenet létrejöttéhez a csapadék al-index is hozzájárul, szerepe ugyanakkor elhanyagolható az $m C I d$ taghoz képest (6.2.e. ábra). A csapadékkal ellentétben a napfénytartam al-index $(S)$ - a napi napfénytartam téli minimuma és nyári maximuma miatt - nyáron nagyobb mértékben járul hozzá az index értékéhez, így a bimodális szerkezetet kissé tompítja, a nyári csúcsot pedig elősegíti (6.2.f. ábra). A nyári csúcs kialakításához a szélsebességindex is hozzájárul kismértékben (6.2.g. ábra).

\section{A vizsgált területek klímapotenciáljának összevetése}

Amennyiben áttekintjük a többi hazai terület (Budapest, Siófok, Debrecen, Pécs, Győr) TCI/mTCI-alakulását, elmondhatjuk, hogy mindegyik nyári csúccsal jellemezhető a TCI alapján, míg bimodális szerkezettel az mTCI szerint (6.3.a-d. ábra). Valamennyi helyszín a júniusinál kedvezőtlenebb körülményekkel rendelkezik júliusban és augusztusban. Szembetűnő, hogy Siófokon június és július dekádjaiban némileg kedvezőbb klimatikus viszonyok találhatók a többi városhoz képest (a TCI 90 körül vagy kissé afelett, az mTCI kevéssel 70 alatt alakul). E különbség kialakulásában mindenképpen nagy szerepe van a szélsebességindexnek $(W)$, ugyanis Siófokon magasabb átlagos szélsebességek detektálhatók, és ebben az időszakban Mieczkowski „passzát szélrendszer” kategóriarendszere érvényesül a területen, amelyben a szélsebességértékek éppen a maximálisan adható 5 értékelő pontot jelölik ki (2.5. ábra). A többi városban ugyanakkor súlyozva 2-4 ponttal kisebb $W$-érték adódik (Függelék 3.a-7.a. ábra).

A külföldi területek esetében változatosabb kép bontakozik ki (6.3.e-f. ábra). A TCI-t tekintve Prágában és Berlinben a magyarországi helyszínekhez hasonlóan a nyári időszak rendelkezik a legkedvezőbb körülményekkel, ami általában kitünőt jelent $(80<\mathrm{TCI}<89)$ (6.3.e. ábra). Szembetűnő ugyanakkor, hogy a május és a szeptember néhány értékkel kedvezőtlenebbnek mutatkozik a magyarországinál. Ennek oka világosan magyarázható a nagy súllyal bíró $C I d$ al-index értékeiből következően, mivel az említett helyszíneken a „nappali” maximális PET-ek értéke alacsonyabb. Érdekesség, hogy Berlinben és Prágában a legterhelőbb nyári dekádokban nem jelenik meg a $C I d$-értékek csökkenése, ellentétben a hazai helyszínekkel (Függelék 8.a-9.a. ábra). 
$\mathrm{TCl}$
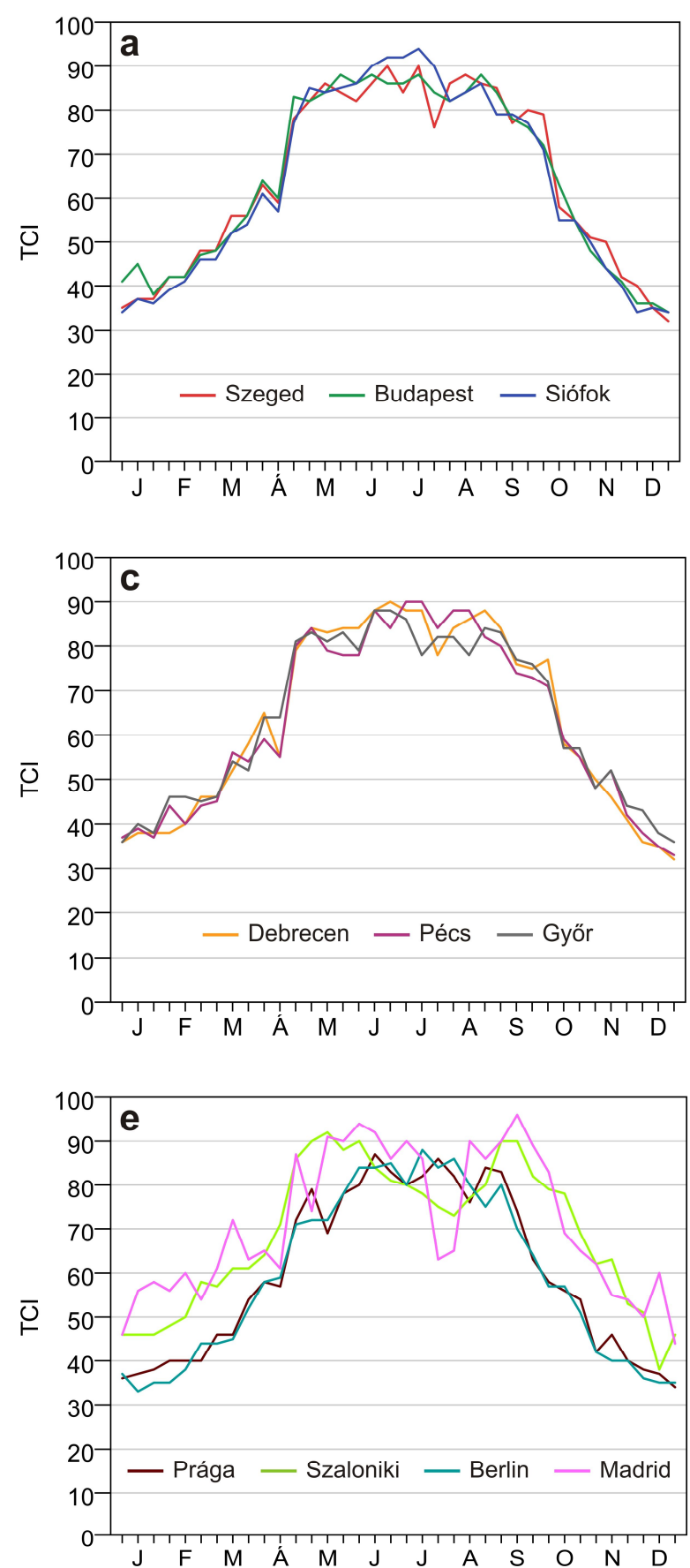

$\mathrm{mTCl}$
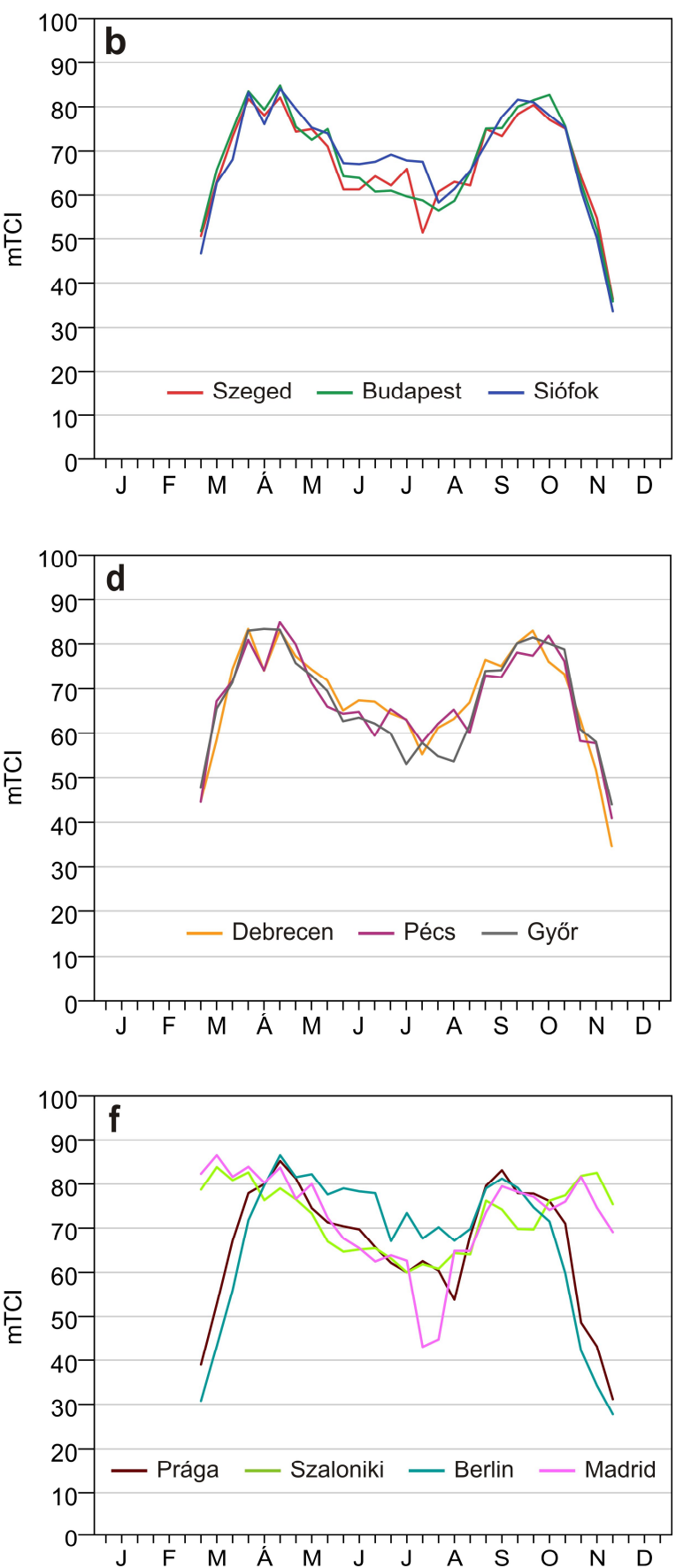

6.3. ábra: A TCI és az mTCI évi menete a vizsgált turisztikai célterületekre tíznapos felbontásban (Szegeden, Budapesten, Siófokon és Debrecenben az 1996-2010, Pécsen, Győrben, Prágában, Szalonikiben, Berlinben és Madridban a 2000-2010 időszakra vonatkozóan)

Madridban és Szalonikiben már a TCI eloszlása is bimodális jelleget mutat, ami Szaloniki esetében kifejezettebb: egészen június elejétől szeptember elejéig kissé visszaesnek az értékek (6.3.e. ábra). A nyári visszaesések egyik fö okozója is a CId tagban keresendő, ami mindkét déli régióban bimodális jelleget mutat, sőt Szalonikiben a „nappali” átlagos PET-en alapuló CIa tag hozzájárulása is kisebbnek adódik néhány nyári dekádban. Látható az is, hogy a kis csapadék (magas $R$-érték) és a nagy napfénytartam (nagy $S$-érték) a bimodális jelleg ellen dolgozik a két városban, ugyanakkor ezek hatása kisebb súlyértékük miatt kevésbé érvényesül (Függelék 10.a-11.a. ábra). Madridban a bimodális jelleg tekintetében csak egy rövidebb, 
viszont jelentős visszaesés látható: július utolsó és augusztus első dekádjában jónak minősülnek az éghajlati viszonyok, egyébként közel ideálisnak mutatkoznak (6.3.e. ábra). E csökkenésért egyértelmüen a szélsebességindex tehető felelössé. A spanyol területen ugyanis a sehol máshol nem jelentkező több mint $33{ }^{\circ} \mathrm{C}$-os átlagos nappali maximum-hömérséklet adódott e két dekádban, amely esetben a „forró klíma” elnevezésű szélsebességértékelő-pontok használandók (2.5. ábra). A viszonylag erős szél e meleg nappali időszakban pedig olyan komoly terhelést okoz, hogy ez mindössze 0,5 vagy 0 pontot eredményez (Függelék 10.a. ábra). E nyári csökkenést leszámítva ugyanakkor a déli területeken csaknem egész évben kedvezőbb turisztikai klimatikus körülmények detektálhatók, ami a magyarországi helyszínekhez képest általában egy, míg az északi régiókhoz képest egy vagy két kategóriányi javulást jelent. Ennek okozója elsősorban a nagyobb értékü CId tagok, másodsorban az egész évben jellemző magasabb $S$-értékek.

Az mTCI esetében a magyar helyszínekhez hasonlóan mindegyik külföldi célterületen bimodális szerkezet mutatkozik, ám jelentős eltérések fedezhetők fel (6.3.f. ábra). Berlinben a nyári visszaesés mértéke csekélyebb (körülbelül egy kategóriányi), míg a többi területen egyöntetűen több mint két kategóriányi hanyatlás jelentkezik. E különbség oka, hogy a német területen kisebb mértékü a nyári $m C I d$-visszaesés, vagyis ebben az időszakban ott olyan maximum PET-ek adódnak a nappali órákban, amelyek kevésbé terhelőek, így értékelésük magasabb ponttal történik, mint a többi területen (Függelék 8.a. ábra). Madridban még ezenfelül - mint ahogy a TCI-nál is láttuk - július végén és augusztus elején az éghajlati viszonyok jelentősen kedvezőtlenebbé válnak ( $40<\mathrm{mTCI}<49$, semleges), amely nyilvánvalóan most is a $W$-indexszel magyarázható. Április és szeptember környékén mind a négy régióban hasonlóan magasan, 80 körül alakul az mTCI értéke, ugyanakkor márciusban és októbernovemberben az északi területeken jóval kedvezőtlenebbek a körülmények, ellenben Szalonikiben és Madridban hasonlóan vagy még kedvezőbben alakulnak, ami 40-50 körüli mTCIkülönbséget alakít ki az északi és a déli régiók között (6.3.f. ábra). Ennek az az oka, hogy az északi területeken ekkor a hidegterhelés fokozódása kisebb $m C I d$ - és $m C I a$-értékeket generál (Függelék 8.a-9.a. ábra), míg délen ezekben az időszakokban is igen magas (esetenként a legmagasabb) értékek mutatkoznak. A madridi és szaloniki magasabb napfénytartam (így $S$ érték) is kismértékben hozzájárul e különbséghez (Függelék 10.a-11.a.ábra).

\subsubsection{Klíma-Turizmus-Információs-Rendszer}

A következőkben a klimatikus és bioklimatikus adatok gyakorisági eloszlásán alapuló CTIS-eredményeket mutatom be a vizsgált helyszínekre. Az eredmények jelen esetben is csak a nappali időszak adataira támaszkodnak. Elsőként a termikus paraméterek gyakoriságát vizsgálom, mind a hagyományos PET-stresszkategóriák, mind a magyar lakosokra adaptált hőérzeti értéktartományok alapján. A termikus komponensek elemzése után az esztétikai és a fizikai komponenseken alapuló eredményeket mutatom be.

Szeged klímapotenciáljának elemzése

Elsőként jelen esetben is Szeged városát elemzem részletesen, amelyre vonatkozóan kétféle ábrázolási módszeren alapuló eredményt is bemutatok (6.4. ábra). Az egyik megjelenítési 
mód a gyakoriságok egyszerü, százalékos kifejezésén (6.4.a. ábra), míg a másik a CIT-alapú turisztikai értékelésekben használatos hétfokozatú diszkrét skálán alapul (6.4.b. ábra).
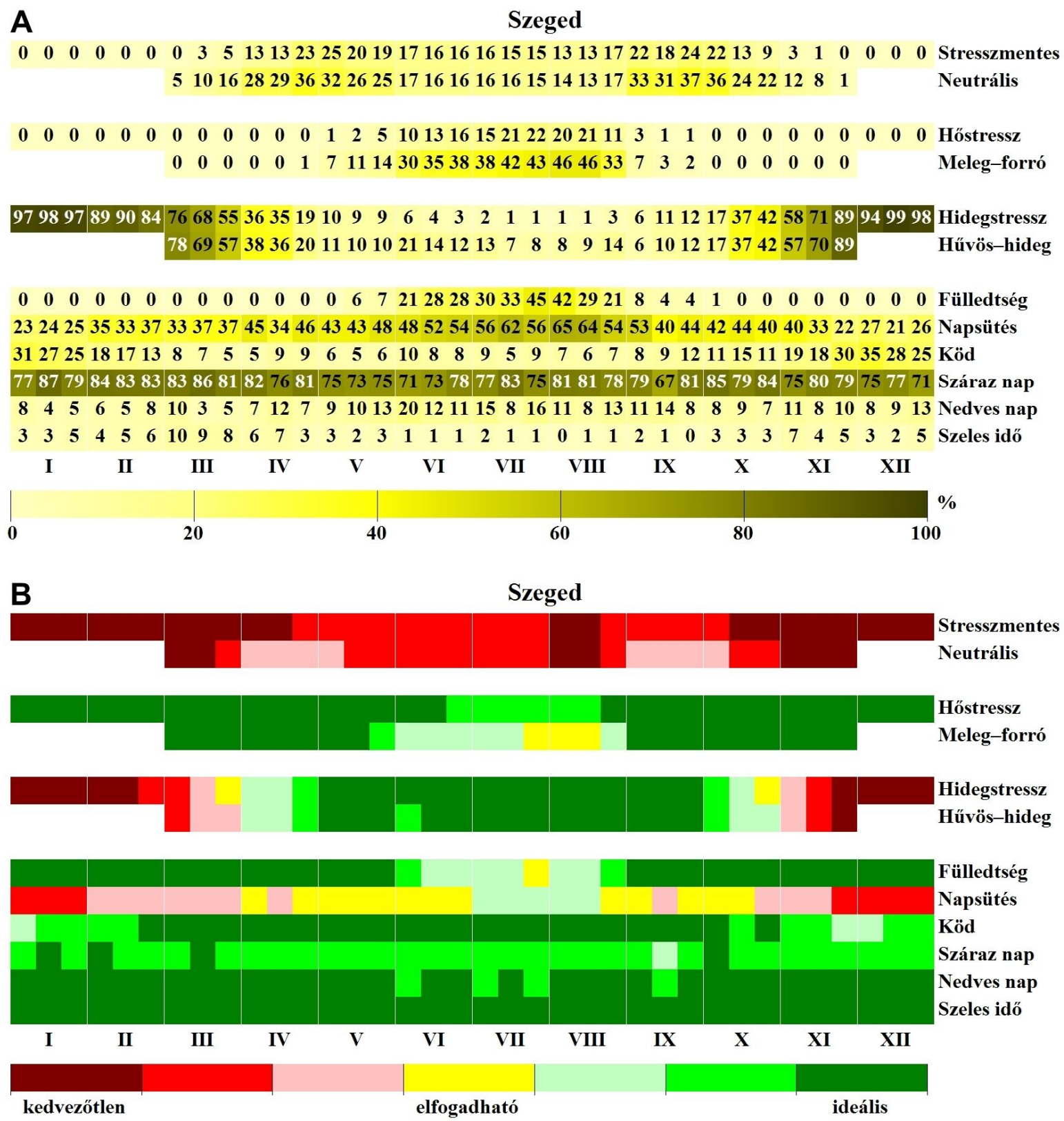

6.4. ábra: Klíma-Turizmus-Információs-Rendszer (CTIS) Szegeden tíznapos felbontásban (1996-2010), interpolált színskálával (a), illetve hétfokozatú értékeléshez rendelt diszkrét színekkel (b) ellátva. A termikus stresszre és a höérzetre vonatkozó küszöbértékek az 5.3. táblázaton, a többi paraméteré a 2.5. táblázaton alapulnak

Az első módszer esetében a különböző jellegű paraméterekhez köthető színasszociációk (pl. hideg - kék, meleg - piros) kiküszöbölése érdekében egy semleges színárnyalatú (sárgászöld) ábrázolási mód mellett döntöttem (6.4.a. ábra). Termikus szempontból stresszmentes viszonyok legnagyobb gyakorisággal (20\% körül) április utolsó dekádjában, májusban, szeptemberben és október első dekádjában fordulnak elő. A felmérések révén levezetett, a magyar lakosok által neutrálisnak érzett viszonyok alapján a kedvező feltételek nagyobb gyakorisággal fordulnak elő az említett időszakokban (kb. 25-35\%). Nyáron a neutrálisnak érzett körülmények gyakorisága csupán 15\% körüli, ami hasonló az eredeti küszöbértékek által jelzetthez. 
Meleg-forró hőérzetet eredményező viszonyok elsősorban nyáron fordulnak elő, mégpedig 35-45\%-os gyakorisággal. A magyarok hőérzetére alapozott értékelés általában több mint kétszer gyakrabban jelez kedvezőtlen viszonyokat, mint amit az eredetileg definiált höstressz küszöbérték alapján mondhatunk.

A magyar emberek által hüvösnek és hidegnek érzett körülmények előfordulása a nyarat kivéve csaknem megegyezik az eredeti hidegstressz küszöbérték alapján vett gyakoriságokkkal a teljes vizsgált időszakban. A legmagasabb gyakorisági értékek kora tavaszra és késő őszre összpontosulnak 60-90\%-kal. Az eredeti küszöbérték télre 85-100\% gyakoriságú hidegstresszt jelez. A nyári időszakban lényegében nem fordul elő hidegstressz, viszont olyan körülmények, melyeket a magyar emberek hidegnek vagy hüvösnek éreznek, kissé nagyobb gyakorisággal fordul elő, különösen a nyár első felében (ugyanakkor ez bizonytalanabb eredménynek tekintendö, mivel a kérdöíves adatbázis alapján a hüvös és a hideg PETtartományok határát nem lehetett levezetni; 5.2. ábra, 5.3. táblázat).

Az ugyancsak a termikus csoportba tartozó fülledt viszonyokat csak május második dekádjától október első dekádjáig tapasztalhatunk, de a 20-45\%-os gyakoriságával nyáron fordul elő számottevő mértékben. Az esztétikai komponensnek számító napsütés gyakorisága június közepétől szeptember első dekádjáig meghaladja az 50\%-ot, előfordulásának minimuma (25\% körül) pedig decemberben és januárban található. Ködös körülmények a legnagyobb valószínüséggel november végétől január végéig alakulhatnak ki. Száraz nap kb. 65-85\%-os gyakorisággal fordul elő az év folyamán, a kisebb értékek főként májusra és júniusra összpontosulnak. A nedves napok előfordulási gyakorisága általában 15\% alatt marad, s legnagyobb valószínűséggel májustól szeptemberig fordulnak elő. Szeles idő leginkább márciusban és áprilisban tapasztalható, de gyakorisága még ekkor is $10 \%$ alatt marad (6.4.a. ábra).

A diszkrét színekkel kódolt turisztikai értékelő skála szerint (6.4.b. ábra), akár a stresszmentes, akár a neutrálisnak érződő viszonyokat tekintjük, az elfogadhatónak számító gyakoriságnál (42-56\%) mindig alacsonyabbat kaptam, vagyis valamilyen mértékben kedvezőtlen körülményeket találunk a dél-alföldi területen. A legkedvezőtlenebb viszonyok télen, tavasz elején, ősz végén és augusztus első két dekádjában jelennek meg. Az eredeti stresszmentes kategóriát alapul véve vagy ugyanolyan, vagy egy kategóriával kedvezőtlenebb viszonyokat kaptam eredményül.

Hőstressz szempontjából még a nyári időszak is csak egy kategóriával marad el az ideálistól. Ugyanakkor a meleg-forró hőérzet tekintetében a július vége, augusztus eleje és közepe mindössze elfogadhatónak minősül, s a többi nyári dekád esetén is csupán egy kategóriával kedvezőbb az állapot. A nyarat nem számítva az esetlegesen előforduló hőstressz vagy meleg höérzet nem ront az ideális körülményeken.

A hidegstressz és a hűvös-hideg hőérzet csekély mértékủ előfordulása májustól szeptemberig ideálisnak minősül. A többi időszakban is ugyanarra a minősítésre vezet a kétféle megközelítés, s általában dekádról dekádra egy-egy kategóriával kedvezőtlenebb viszonyokra (10-15\%-kal nagyobb előfordulási gyakoriságokra) számíthatunk. Télen a gyakori hidegstressz abszolút kedvezőtlen körülményeket okoz.

A fülledtség nyáron némiképp csorbítja az időjárási viszonyok élvezeti értékét, így július végén már csak elfogadható minősítésre vezet. Júliusban és augusztus első két dekádjában jelez kedvező képet a napsütésre vonatkozó értékelő sor, de ideális körülményeket ekkor sem várhatunk. Áprilistól június végéig és augusztus végétől október végéig még elfogadható, míg decemberben és januárban már kedvezötlen a napsütés mennyisége. Ködös körülmények álta- 
lában novembertől februárig fordulnak elő, de az elfogadhatónál mindvégig kedvezőbbek maradnak. A nedves napok előfordulási gyakorisága szempontjából néhány nyári dekádot leszámítva ideális viszonyokat várhatunk, és a száraz napok gyakorisága alapján is csaknem ideális kép mutatkozik. A szelesnek minősülő körülmények alacsony előfordulási gyakorisága valamennyi dekádban ideális minősítéssel értékelhető (6.4.b. ábra).

A fentieket összegezve Szegeden a városi turizmusra való legalkalmasabb időszaknak a májust és a szeptembert tartom. Ekkor hőstressz és hidegstressz nem jellemző, a termikus stressztől mentes körülmények pedig a legnagyobb valószínüséggel fordulnak elö. A neutrálisnak, meleg-forrónak s hüvös-hidegnek érzett viszonyok tekintetében is kedvezőnek minősülnek e periódusok. A fizikai és az esztétikai paraméterek alapján is megfelelőnek értékelhetők ezek az időszakok, egyedül a nagyobb valószínüséggel előforduló csapadék jelenthet némi bizonytalanságot.

\section{$\underline{\text { A vizsgált területek klímapotenciáljának összevetése }}$}

Összehasonlítva Szegedet a többi magyar helyszínnel, a stresszmentes és a neutrálisnak érzett viszonyok, valamint a hidegstressz és a hüvös-hideg hőérzet gyakoriságában csak kis különbségeket találhatunk. A hőstresszel jellemezhető, valamint a melegnek és forrónak érzett körülmények előfordulása Debrecen és Siófok esetében általában néhány százalékkal kisebb gyakoriságokat mutat a többi területhez képest (6.5. ábra). Fülledt viszonyok a nyári dekádokban Budapesten fordulnak elö a legkisebb, míg Siófokon, Debrecenben és Szegeden a legnagyobb gyakorisággal. Ezen belül is kiemelendő a balatoni térség, ahol valamennyi dekádban a legnagyobb - július közepétől augusztus közepéig több mint 50\%-os - valószínüséggel számíthatunk fülledt körülményekre. A napsütést tekintve a legnagyobb előfordulási gyakoriságok nyáron Siófokon és Szegeden figyelhetők meg. A ködös időszakok tekintetében általában Győrben mutatkoznak a legkisebb gyakorisági értékek, míg e körülmény Szegeden, Debrecenben és Siófokon okoz nagyobb valószínűséggel kedvezőtlenebb viszonyokat. A száraz és a nedves napok előfordulásában Szegedhez viszonyítva csak kisebb különbségek mutatkoznak. A szeles időszakok Szegedhez képest általában kisebb gyakorisággal fordulnak elő, mely alól kivétel Siófok, ahol az egész év folyamán a leggyakrabban fordul elő a hazai városok közül (6.6. ábra).

A külföldi helyszíneken a TCI/mTCI-értékeléshez hasonlóan nagyobb különbségeket és eltolódásokat találunk a magyar területekhez képest (6.5-6. ábra). Prága és Berlin esetében a hőstresszmentes és a neutrálisnak érzett viszonyok tekintetében szembetűnő, hogy a nyári dekádokban néhány százalékkal nagyobb gyakoriságokkal fordulnak elő. Az átmeneti évszakokban mindkét körülmény gyakorisága hasonlónak vagy némileg kisebbnek adódik, mint a magyar területeken. Szaloniki és Madrid esetében jelentős eltérések mutatkoznak nyáron a többi helyszínhez képest, akárcsak a TCI-értékelés esetén. Ugyanis mind a stresszmentes, mind pedig a neutrálisnak érzett viszonyok mindössze néhány százaléknyi gyakorisággal fordulnak elö, ami júliusban és augusztusban, valamint a görög régió esetén a legkifejezettebb. Tavasszal és ősszel jelen esetben is kedvezőbb feltételek mutatkoznak, s a maximális gyakoriságokkal rendelkező időszakokban megfigyelhető egy eltolódás a tavasz kezdete s az ősz vége felé. Például Szaloniki esetében április első két és október utolsó két dekádjában számíthatunk a legnagyobb valószínűséggel (közel 50\%-os gyakorisággal) neutrálisnak érzett körülményekre. 
Prágában és Berlinben a hőstresszel jellemezhető viszonyok szinte elhanyagolható mértékben fordulnak elő. A magyar lakosok hőérzetére alapozott értékelés e területeken is gyakrabban jelez kedvezőtlen viszonyokat, de a magyar területekhez képest jóval kisebb gyakorisággal fordulnak elő meleg-forró hőérzetü körülmények. A két északi helyszínt összehasonlítva, a cseh területen mutatkoznak kissé nagyobb gyakorisággal kedvezőtlen körülmények. Madrid és Szaloniki térségében a hőstressz és a meleg-forró hőérzet gyakoriságát elemezve drasztikusan kedvezőtlenebb viszonyokat találunk. Hőstresszes körülmény július közepétől augusztus közepéig kb. 50\%-os gyakorisággal fordul elő a két területen, míg a meleg-forró hőérzet esetében még ennél is jóval kedvezőtlenebb körülményeket várhatunk nyáron, melynek gyakorisága Szalonikiben megközelíti a 90\%-ot. Megfigyelhető az is, hogy a két déli régióban a magyar és az északi területekhez képest nagyobb valószínüséggel fordulnak elő kedvezőtlen körülmények a májusi és a szeptemberi dekádokban is.

Az erős hidegstresszel jellemezhető és a hűvös-hideg hőérzetű viszonyok gyakoriságának alakulása a külföldi területeken a magyarországihoz hasonlóan alakul, vagyis a tél felé haladva fokozatosan nagyobb valószínüséggel számíthatunk kialakulásukra. Ugyanakkor a gyakoriságok nagyságában és időbeli alakulásában jelentős eltolódásokat találunk. Berlin és Prága térségében a magyar viszonyokhoz képest nagyobb gyakorisággal fordulnak elő, és májusban, valamint szeptemberben sem elhanyagolhatók. A déli helyszíneken ugyanakkor az erős hidegstresszel jellemezhető, valamint a hűvösnek és hidegnek érzett viszonyok leginkább csak a téli hónapokra szorítkoznak, és jóval kisebb valószínüséggel számíthatunk rájuk, mint a többi területen. Hidegstresszes viszonyok nyáron nem jellemzők a külföldi területeken, a szubjektív hőérzetalapú értékelés viszont az északi helyszínekre kissé nagyobb mértékben jelez kedvezőtlen viszonyokat (ám ez bizonytalanabb eredménynek tekintendö, 5.3. táblázat) (6.5. ábra).

Fülledt viszonyok Prágában és Berlinben kisebb gyakorisággal fordulnak elő a hazai területekhez képest, s leginkább júliusra és augusztusra szorítkoznak. Madridban a fülledtség kialakulása elhanyagolható, ugyanakkor Szalonikiben nyáron szinte mindennapos eseménynek számít. Legnagyobb valószínűséggel augusztus első két dekádjában számíthatunk rá (85 és 84\%), s figyelemre méltó, hogy májusban, szeptemberben, valamint októberben is számottevő mértékben tapasztalhatunk itt fülledt viszonyokat. Napsütéses viszonyok az északi régiókban szinte mindegyik dekádban kisebb, a déli területeken pedig nagyobb gyakorisággal fordulnak elő, mint Magyarországon. A két déli helyszínen még az átmeneti és a téli évszakokban is viszonylag kiegyenlítetten magas gyakorisággal számíthatunk napsütésre, június utolsó dekádjától augusztus végéig pedig a mennyisége eléri a 85-90\%-ot is. Köd az északi területeken ősszel kissé nagyobb valószínüséggel fordulhat elö, mint a hazai helyszíneken, télen viszont fordított a helyzet. A déli régiókban kevésbé jellemzőek a ködös viszonyok, de különösen a görög térségben késő ősztől február végéig nagyobb valószínűséggel számíthatunk rá, ám a mértéke nem éri el a Magyarországon tapasztalhatót. A déli helyszíneken a nyár összes dekádja ideálisnak tekinthető a csapadékkal kapcsolatos események tekintetében. Ösztől tavaszig viszont gyakrabban jelennek meg csapadékos időszakok, esetenként a magyarországinál is nagyobb gyakorisággal. Prága és némileg kisebb mértékben Berlin térségében - a magyar területekhez hasonlóan - nyáron adódik a legnagyobb valószínüséggel nedves nap. Száraz nap némileg kisebb arányban fordul elő e két városban a magyar területekhez képest. A legtöbb hazai helyszínhez hasonlóan a szeles viszonyok előfordulási gyakorisága az északi területeken kicsi, míg a görög és a spanyol régióban novembertől áprilisig nagyobb gyakorisággal teheti kedvezötlenebbé a körülményeket (6.6. ábra). 
What

T근 ป⿻

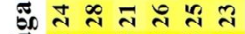

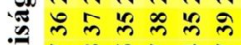

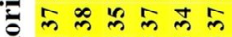
ल के ले ले लै है लै ले 두 $\infty$ 으

인ำㄴ

호는

กู่

诃

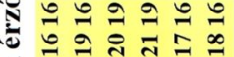

든ำ

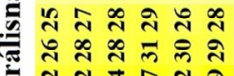

जूले ले लू ले

లొ లో లో

ते ले ले क्रे ले ले

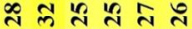

으는 그

음 $=\mathbb{I}$

n $+\mathrm{N}+\mathrm{m}$ 잘

o o a

$\left.0-\frac{1}{4}\right)^{2}$

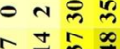

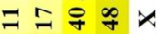

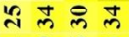

के ते ट्ष

ले

7)

जै की

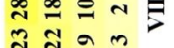

$\tilde{\pi} \vec{\sim} \infty \mathrm{N}$

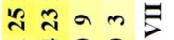

त $\overrightarrow{4} \varrho 0$

तิ

तั

तิ $⿻$ 느

लै लै సี

के केते =

कि से स्त

ले लै

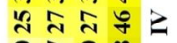

등

๑ $\approx$ ส

तथल क्ष

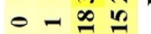

\section{Whys}

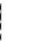

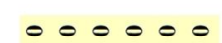

o 0000

o 0000

$\theta \theta \theta \theta 0$

$\theta \theta \theta \theta \theta$

o $\theta 0 \theta 0$

$\overbrace{0}^{0} N-T-N-$

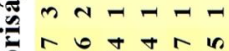

- $10+7 r$

ले ले है ले लै

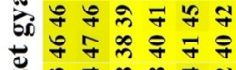

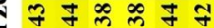

行 ๆ

क ले ले ते है

ॠ ले ले ले ले

है ले त्र ते ले ले

ธิ ले ले ผै

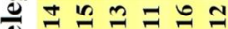

$\exists=\infty+r$

a 0 o t n

$A 4 \rightarrow-4 a$

- 0000

$\theta \theta \theta \theta \theta$

$\theta \theta \theta \theta \theta$

$\theta \theta \theta \theta \theta$

000000

\section{可}

0000

00007

$000-1$

$00-N$

$0 \theta-n x$

o 0 n

$0-0 b$

$0-g r \dot{u}$

- m i 2

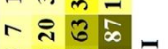

ป

กิ

古 $\bar{m}$ i $\infty$

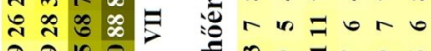

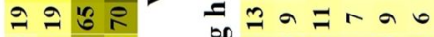

อ

은ำกับ

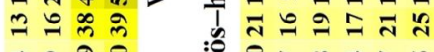

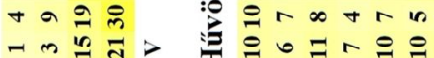

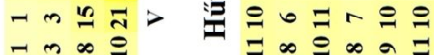

(

o o or

$\theta e \theta+$

$\theta \theta \theta$

$0=--\ldots$

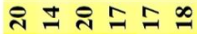

ले ल ले స्ल ले

क्ले लै ले ₹

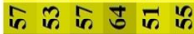

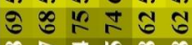

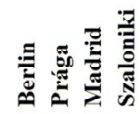

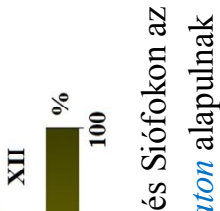

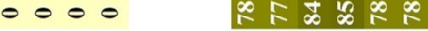

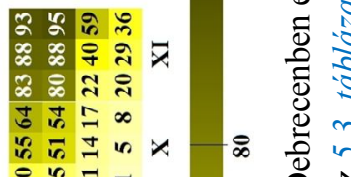

द्व

$\pm \cong+\theta$

$r \infty-\theta$

กิป

$2 \approx n 0 \equiv$

IN

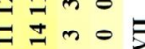

तิ ने

तิ ने $\mathrm{N}$

ลูกิ

ते ले $\simeq$

능의

$\infty \sim \infty 0$

긍

มิ

ๆ ศึำ

जี in

(6) 8 ले

एव ल ल

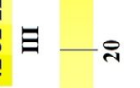

胥

=

$$
=
$$

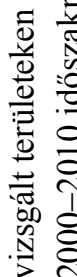

Whys

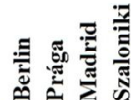

Fivis

$\begin{array}{lll}0 & 0 & n \\ 0 & 0\end{array}$

- $\theta \theta \theta \theta$

$\theta \theta \theta \theta \theta$

Fo 0000

mNm-ma

a $\infty$ a 0 I

药 2 a

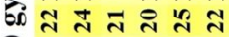

ชิ

$\infty \stackrel{4}{\sim} \underset{\sim}{4} \tilde{ก}$

ส

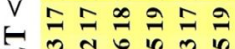

미름

드는두

$\checkmark \div 6$ ำ

บำลี

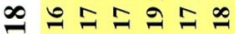

$=\bar{\imath}-\infty \overline{0}$

능

도 $\infty \propto \infty \pm$

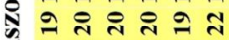

गิ

ग एँ

అ

은 1206

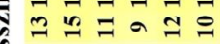

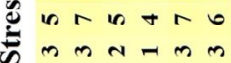

o $\theta-\theta 0$

$\theta \theta \theta \theta \theta$

$\theta \theta \theta \theta 0$

$\theta \theta \theta \theta \theta$

$\theta \theta \theta \theta \theta 0$

- $\theta 0 \theta 0$

$\theta \theta-\theta$

$0 \sim$

0 o a b

$00 \pm 2$

- m

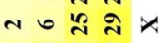

เปกิ สิ

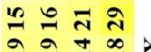

의

$\overline{\text { ก }}=$

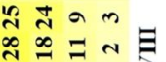

ส तथल

4

4 ส

तै ते 2

ㅇํㄹ

든

$\stackrel{2}{2} \stackrel{2}{2}$

그류 눈

ㅊำ

च

ำ 구

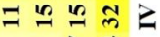

$m$ 들

$n+Z \cong$

- - 9 目目

$\theta=\infty b$

r 음

o enr

$0 \theta+a$

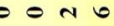

$00 N+$

0000

- 0000

I $\theta 00 \theta 00$

To 00000

000000

$\theta \theta \theta \theta 0$

$\hat{3}_{0} 00000$

Oे $\theta 0 \theta 00$

䜣 $-00-00$

$\Lambda-00000$

I

되 $\exists a \infty$ n $a$ 의

ㄱิ

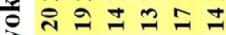

ปี่

สีก

느음

느의

$2 \simeq r=2=$

음 $=$ a

and a n w

a erath

可 $0=0$

S $\theta 0 \theta 0$
00000

000000

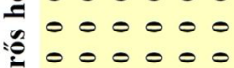

a 00000

000000

$0 \theta 000$

- 0000

- $\theta 0 \theta \theta$

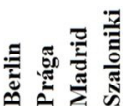

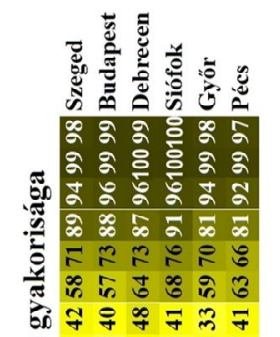

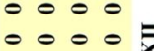

000

000

$0000 \not$

$\theta \theta \theta 0$

$000-1$

$00-x$

$\theta \theta-m$

$0=n+$

$00 \infty+\underline{x}$

$0- \pm \infty$

- $\nabla$ ले लै

ल ब हैं है

๙

$\infty \approx \frac{\pi}{2}$

$\infty \simeq$ ก

- $10 \begin{gathered}\infty \\ -\infty\end{gathered}$

त ले ले

$m+4 \pi /$

a t 음

tes $a$

$0-n b>$

$0-r m$

$\theta \theta-t$

$\theta \theta=m$

$000-$

$000-$

0000 列

o 000

0000

- 000

0000

0000

00001

$\theta 0 \theta$

कि

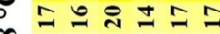

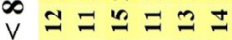

$\forall=\wedge \infty \infty$

됨 $0 m=m$ in 


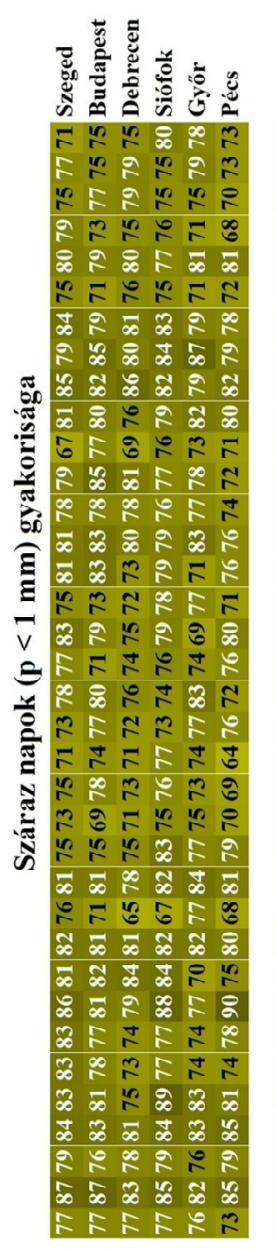

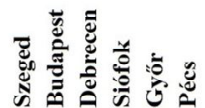

00000

or $\theta 0$

$\theta \theta \theta \theta \theta$

c $\theta=0$ o

o 00000

000000

o 0000

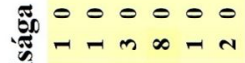

角 $+4+0-1$

$\int_{0} \infty+0 \Omega$

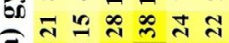

ॠ

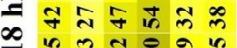

舫

$\wedge$ ले

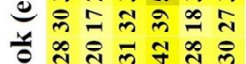

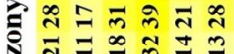

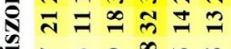

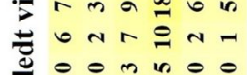

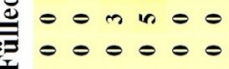

$\theta \theta \theta \theta 0$

e $\theta \theta \theta$

$\theta \theta \theta \theta$

c $\theta=\theta 0$

000000

00000

- 00000

000000

- 0000

- 0000

$\theta \theta \theta \theta \theta$

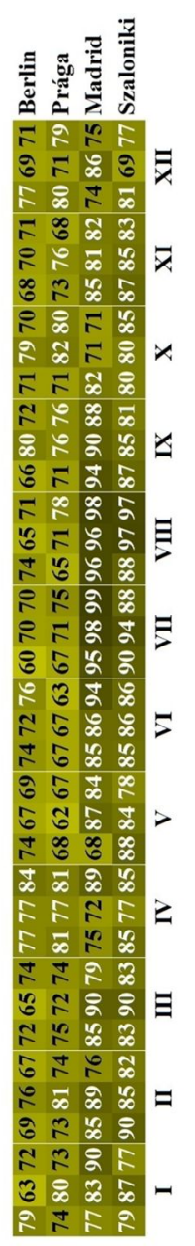

돌

- 00

$\theta \theta \theta$

$\theta \theta \theta$

o $=0$

o o o N

o o on

- 002

$00-\stackrel{\infty}{=} x$

- 0 ते

- $0-$ ल

m n

1- 1 a

ปี

ลิ $2 \sim \mathscr{\infty}$

$\stackrel{\sim}{\sim}$ 늠

范

$\because \frac{0}{-1}-1$

$=\infty \times \sigma$

च J十 5

1- 으 =

- no

000 I

$\theta e=m$

$=0 \mathrm{r}$

- $0-1$ l

$\theta \theta \theta$

$\theta \theta \theta$

co 00 目

0000

000

- 000 l

0000

- 000

o $00-$

$\theta \theta \theta$

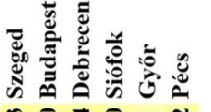
2 은 a a a a b $\infty$ a 음 $=\infty$ 음 $a$ 음 $\infty$ 프 $\infty=r \operatorname{rr}$ $\exists=290 \pm$ $r \Theta \infty+a \triangleq$ $a$ u $=\infty \infty r$

ix $\infty \infty$ u a ve

夹 $\infty=r=a$

ปン

$\exists=\Xi \approx$ 뇍

$2=2 \div 2=$

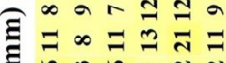
I $) \div$

$\Lambda \infty \approx \pm \cong n$

으능

$\forall= \pm N \cong$ a

产

$\infty 2 \simeq 2 \simeq \longleftarrow$

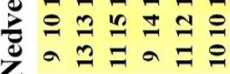

$\therefore=5 N$ -

$r=+\infty$ a 0

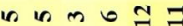

m na mo

으의 $0=r$

$\infty$ a $\backsim \theta \infty \infty$

in in $\mathrm{n}+\ln \mathrm{n}$

b $\infty \infty+1$

na $\infty \infty n$

$+n+n+n$

$\infty \infty a=\infty$

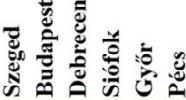

สै

สี สำ

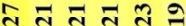

ส

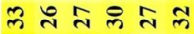

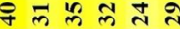

के ले भ भ ले

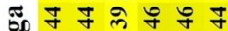

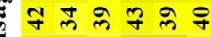

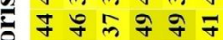

웠

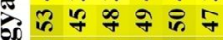

के

$\frac{1}{6}$ in is 6 है 6

$\checkmark$ in in $\begin{aligned} & 6 \\ & 6\end{aligned}$ is in

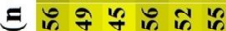

* ํำ

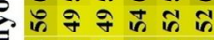

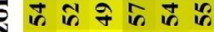

कै 18 ปै

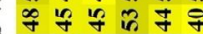

舫

羊

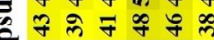

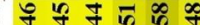

से ले ले लै हे

$\checkmark$ ले ले † ज ले

ก 닌

ले ले के ले से

ले न्ते ले స

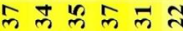

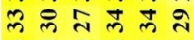

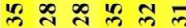

यू

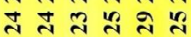

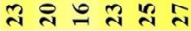

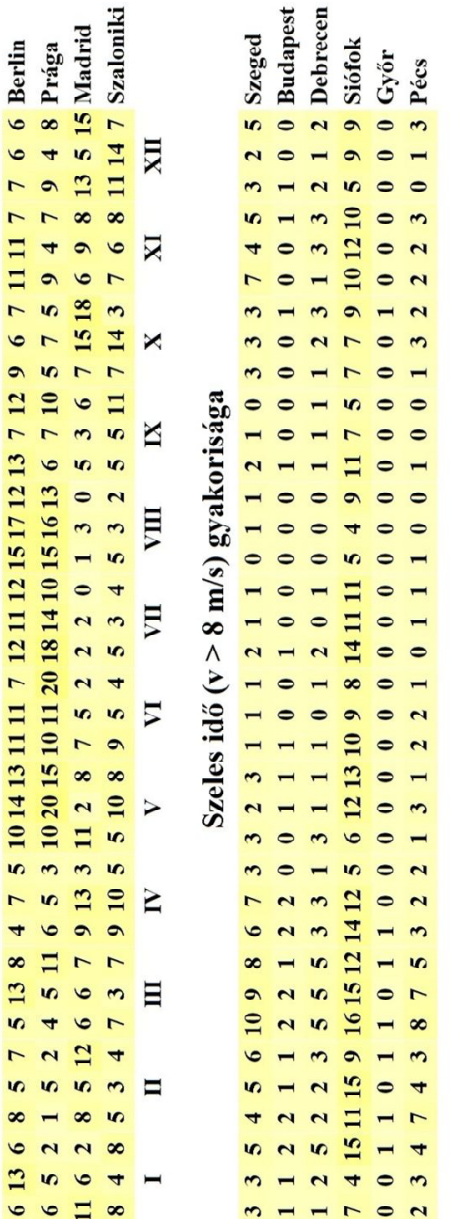

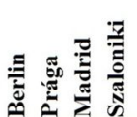

-

I ป ⿵⺆ है

$\infty$ 등

뉴유

๓ กิ ขับ

$\infty \stackrel{\infty}{\infty}$ 约

ते

कल

ते ते है

ว 寻

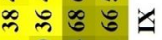

于 मे

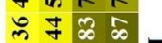

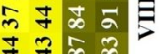

I 7 我

워 궐

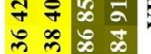

in 10

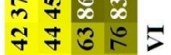

च ले जु ऊु

ल

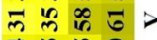

† 15

†

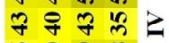



के ले चै अ

กิ

$\infty$ ำ

구

तิ

근

도

4.

(

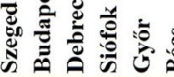

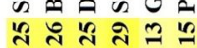

赵节武

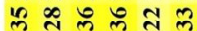

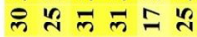

$\infty \stackrel{2}{2} \cong$

$2 \stackrel{2}{2} \cong \simeq$

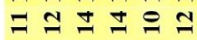

w $\infty$ I $\square$

$=a \stackrel{m}{m} a r$

I $\infty$ 可 $\sim=$

등

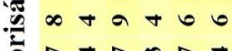

的的的

先 $0 m+4$ an

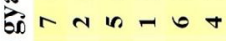

oantota

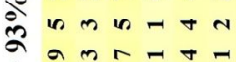

人antat

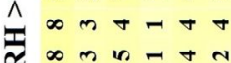

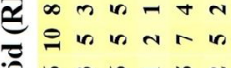

:

0 tan
a

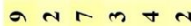

a or mor

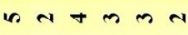

is $t$ in in $\infty$ in

ता a

$\infty \infty \infty \Theta$ in $\infty$

$m a \simeq 2=\infty$

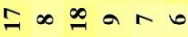

$\infty \approx \widetilde{\pi} \Omega \infty \equiv$

M

तथ 牙的可

कट्ष ते है ज्ञ

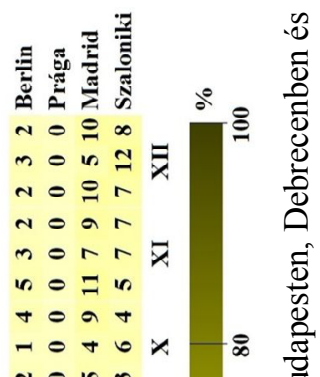

ฮี
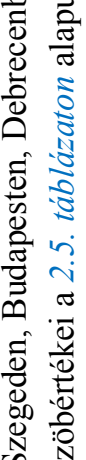

nem $n$

Nomm

$N=$ in $\infty$

nOm

$\rightarrow 00 \mathrm{mE}$

न 0 त

10 क m

ก。+

rem

tema

a $40+2$

to ent

तe $+\mathrm{m}$

4
$H$

No⿱ $=\infty$

$n=\pi$

$--Z N Z$

$--\infty+$

$m-\mathcal{2}$

nobra

-

- - 응

- - 으을 =

o 9

$a \circ 9=$

n $-\exists \infty$

8

(2):

0 en -

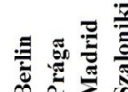

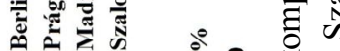

$\infty$ 4ลำ

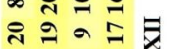

$=\infty \simeq 8$

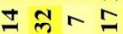

ㄴำ

สิก

ด กิต

m 0

च ने $+m$

$\operatorname{manm}$

$\infty a \theta-x$

$-\infty \theta-$

nnoo

a 000 列

$n=0$

n

$\infty \infty 00 \equiv$

$\infty a 00$

$\infty=-$

+ 0 - 5

1 $=-$

- $\infty$ m -

$\infty \infty n-1$

a $0 \mathrm{mo}$

o tom

$+\infty \sin 1$

+ Tor

a 0 个 $\infty$

or 0 in

0 $\varrho \infty$ in

$\infty$ 음

$\therefore$ a in $a=$

$a \equiv a \approx$

$\exists \equiv \infty$

$\rightarrow \exists \stackrel{\infty}{a}$

$b$ 我 $\infty$

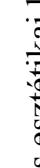

苗

音 
Összegzésként elmondható, hogy a magyar területekhez hasonlóan a külföldi helyszíneken is elsősorban az átmeneti évszakok mutatkoznak a legalkalmasabbnak városi turizmusra. Különösen igaz ez a déli területekre, ahol nyáron mind az erős hőstresszel, mind a meleg-forró hőérzettel jellemezhető viszonyok nagy gyakorisággal fordulnak elö, a stresszmentes és a neutrálisnak érzett körülmények pedig nem jellemzőek. A görög területen emellett a rendkívül fülledt levegő is negatívan befolyásolhatja közérzetünket. A déli helyszíneken még májusban és szeptemberben is gyakran tapasztalhatunk kellemetlen höérzetet eredményező viszonyokat, így ez alapján leginkább az április és az október ajánlható szabadtéri tevékenységekre. Az átmeneti évszakokban viszont már fel kell készülnünk csapadéktevékenységre is. Az északi régiókban még májusban és szeptemberben is nagy gyakorisággal fordulnak elő neutrálisnak érzett viszonyok, és elhanyagolhatóak az erős hőstresszel és meleg-forró hőérzettel jellemezhető körülmények, így leginkább ezek a hónapok kedvezőek. Ugyanakkor ki kell emelni, hogy e területeken még a nyári dekádokban sem rontja komfortérzetünket és közérzetünket számottevő mértékben hőstressz, és a termikus stressztől mentes viszonyok is az átmeneti évszakokhoz hasonló gyakorisággal fordulnak elő. Az északi helyszíneken ugyanakkor - hasonlóan a déli területekhez - éppen a kedvezőnek minősülő időszakokban (májustól szeptemberig) számíthatunk nagyobb valószínüséggel csapadékra.

\subsection{A turisztikai klímapotenciál mintázatának változása}

A következő alkalmazási példa során a turisztikai klímapotenciál változását vizsgálom az éghajlatváltozás tükrében - hazánk területére a TCI és az mTCI segítségével. Mindkét index esetén elöször a jelenlegi turisztikai klimatikus viszonyok alakulását ismertetem (19611990 időszak), majd pedig a jövőben valószínüsíthető körülményeket mutatom be (20212050 és 2071-2100 időszak) (Kovács et al. 2017). A TCI- és mTCI-értékek térképi kategorizálása a 2.3. táblázatban látható kategóriarendszer szerint történt, annyi különbséggel, hogy a 40 alatti TCI-/mTCI-értékeket egy egyetlen, „kedvezőtlen” elnevezésű kategóriába vontam össze.

\subsubsection{A jelenlegi körülmények}

A mérési eredmények alapján a TCI-értékelés decemberre és januárra jelzi a legkedvezőtlenebb turisztikai klimatikus viszonyokat (6.7. ábra). Decemberben a járások 97, januárban pedig 98\%-ában „kedvezőtlen” körülmények uralkodnak. A legalkalmatlanabb időszakok egybeesnek az év leghűvösebb és napfényben legszegényebb periódusával (OMSZ 2015b), amikor a szabadtéri turisztikai tevékenységek - a karácsonyi ünnepkört leszámítva - egyébként sem jellemzőek. A legalkalmasabb időszak a kültéri turisztikai tevékenységek számára júliusban adódik. Ebben a hónapban a járások 99\%-a legalább „kitűnő” klimatikus körülményekkel jellemezhető, sőt az Alföld nagy részén - a hazai járások 25\%-ában - az éghajlati viszonyok minősítése eléri az ,ideális” szintet.

A novemberi és a februári hónapok némileg kedvezőbb viszonyokkal jellemezhetők az említett téli időszakokhoz képest. A „kedvezőtlennek” minősülő járások aránya e két hónapban hasonlóan alakul (14 és 17\%), de eloszlásuk eltérő mintázatot mutat: míg novemberben az ország délnyugati területeire összpontosulnak, februárban jóval elszórtabban jelennek meg. Ahogy novembernek a februári, októbernek az áprilisi mintázat feltethető meg, de ez esetben 

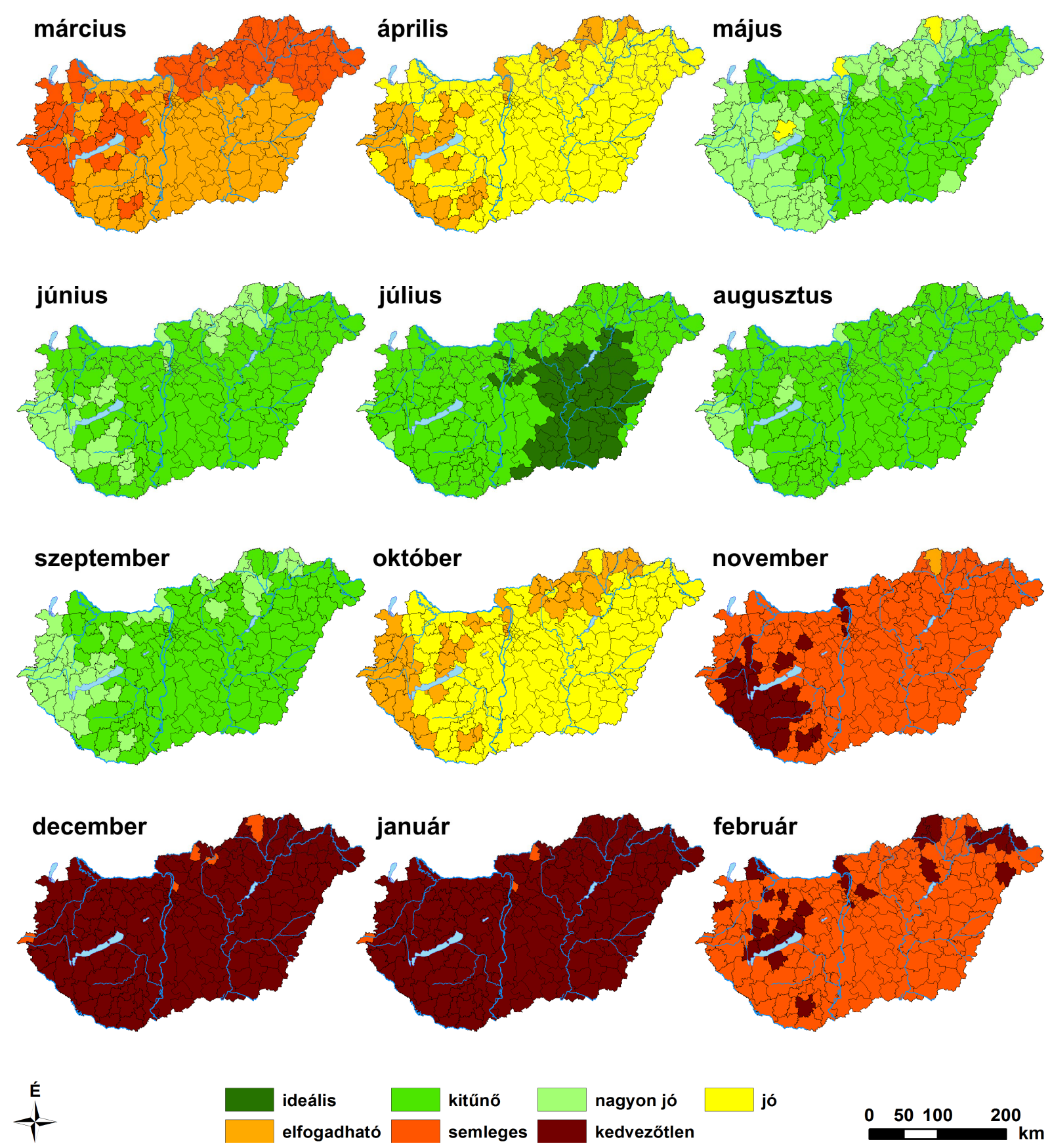

jó

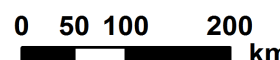

6.7. ábra: A TCI-kategóriák térbeli eloszlása járásonként havi bontásban az 1961-1990 időszakra vonatkozóan

nemcsak a minősítő kategóriák, hanem azok térbeli eloszlása is rendkívül hasonlónak adódik. Ezekben az időszakokban az ország nagyobb részén - beleértve az egész Alföldet - ,jó" körülmények uralkodnak, néhány nyugat-dunántúli és észak-magyarországi járás pedig „elfogadható" klímapotenciállal jellemezhetö.

A májustól szeptemberig tartó időszak kedvező feltételeket teremt a TCI-értékelés szerint, ugyanis „kitűnő” értékeléssel jellemezhető területek dominálnak az ország nagyobb részén. Májusban, júniusban és szeptemberben a Dunántúl nyugati területein és néhány északi járásban „nagyon jónak” minősülő területek is előfordulnak viszonylag magas részaránnyal $(42,20$ és $21 \%$ ), júliusban pedig - ahogyan már említettem - az Alföld nagy részén és a föváros környékén az ,ideálisnak” minősülő viszonyok uralkodnak (6.7. ábra). 

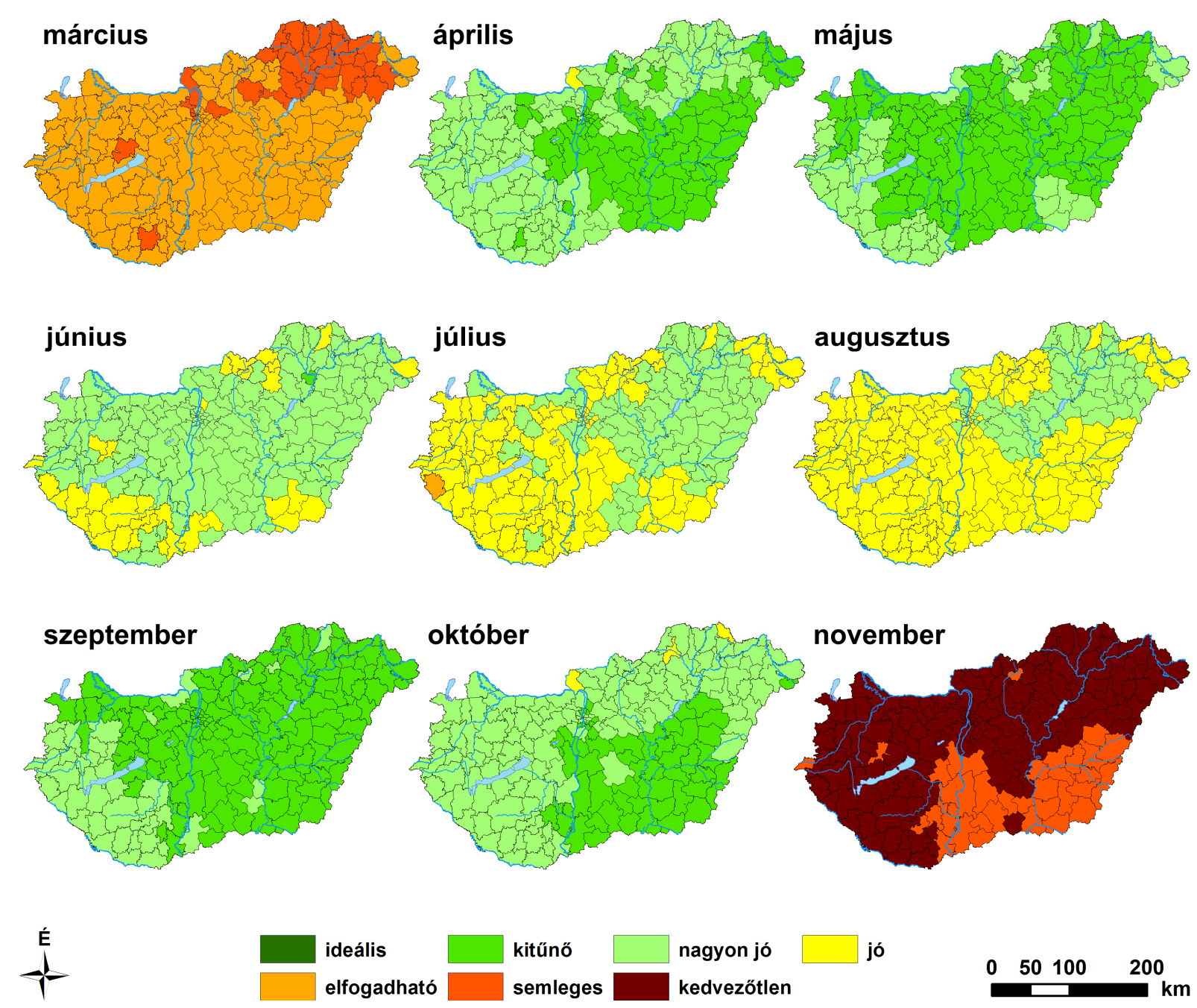

6.8. ábra: Az mTCI-kategóriák térbeli eloszlása járásonként havi bontásban az 1961-1990 időszakra vonatkozóan

A TCI-kategóriák évi alakulását tekintve a jelen alkalmazási példában is megfigyelhetjük a 6.1., 6.3.a. és 6.3.c. ábrák kapcsán már említett „nyári csúccsal” jellemezhető klímapotenciálszerkezetet (6.1.1. fejezet). A téli hónapok (elsősorban a december és a január) adódnak a legalkalmatlanabbnak, míg a nyári időszak minősíthető a legkedvezőbbnek. Jelen esetben is megfigyelhető az a további sajátosság, hogy a kedvezőtlen téli viszonyok után tavasszal intenzíven javulnak a körülmények, május és szeptember között hozzávetőlegesen változatlan viszonyok, majd az ősz folyamán nagymértékü visszaesés tapasztalható (6.7. ábra).

Az mTCI-index évi alakulása is visszatükrözi a turisztikai célterületek mTCI-alapú értékelésénél megfigyelt eloszlást (6.1., 6.3.b. és 6.3.d. ábra) (6.1.1. fejezet). Hazánk területén a legkedvezőtlenebbnek minősülő hónap az mTCI-értékelés szerint a november, melyet a március követ (6.8. ábra). Novemberben a TCI-hoz képest az mTCI az ország jóval nagyobb területére - a Dél-Alföldet leszámítva szinte az egész országra - jelez „kedvezőtlen” viszonyokat (81\%). Márciusban az mTCI mintázata hasonlónak adódik, mint a TCI-é, de ez esetben az mTCI jelez országos viszonylatban kissé kedvezőbb körülményeket. Áprilisban javulás figyelhető meg a turisztikai klimatikus viszonyokban, ami a TCI esetében tapasztaltnál jóval nagyobb mértékü. A javulás tovább folytatódik májusban is, s ekkor már a „kitünő” területek dominálnak az országban, hasonlóan a TCI esetében megfigyeltekkel. Júniustól szeptemberig az mTCI alakulása már nem követi a TCI-ét, ugyanis egy enyhe, de fokozatos visszaesés ta- 
pasztalható (6.7-8. ábra). Megfigyelhető nyáron, hogy fokozatosan növekszik a csupán ,jó” minősítéssel jellemezhető területek aránya a „nagyon jó” értékelés rovására (6.8. ábra). Az mTCI-értékelés általában 1-2 kategóriával mutat kedvezőtlenebb körülményeket, mint a TCI (6.7-8. ábra). Szeptemberben fellendülés mutatkozik a klímapotenciál alakulásában, s az ország nagyobb részén már „kitűnő” körülmények mutatkoznak. E javulás által az mTCI mintázata hasonlóvá válik ahhoz, mint ami májusban tapasztalható. Októberben egy enyhe, novemberben pedig egy drasztikus visszaesés figyelhető meg az mTCI-értékelés alapján (6.8. ábra).

\subsubsection{A jövöben valószínüsíthetö körülmények}

A jövőbeli tendenciák kapcsán első lépésben jelen esetben is a TCI alakulását elemzem. A tavasz elején, márciusban a TCI az „elfogadhatónak” minősülő területek arányának növekedését jelzi a század közepére (6.9. ábra). A század végére pedig már az ország nagy része ilyen minősítéssel rendelkezhet, sőt a déli járásokban a ,jó" viszonyok is megjelennek (6.10. ábra). Áprilisban a század közepére jelentős változás nem valószínüsíthető (6.9. ábra). A későbbi időszakra pedig tovább növekedhet a ,jó" viszonyokkal jellemezhető területek aránya, s csak néhány hegyvidéki járás maradhat „elfogadható” minősítésű (6.10. ábra). Májusban a század közepére kissé növekszik a „kitünő” körülményekkel rendelkező területek menynyisége (6.9. ábra), a század végére viszont további érdemi változás nem valószínűsíthető (6.10. ábra).

A legnagyobb turisztikai forgalommal rendelkező nyári időszakban a tavaszi tendenciával ellentétben kedvezőtlen irányú változásra számíthatunk. Júniusban a „kitűnő” területek aránya csökkenést mutat a század közepére, így az ország nagyobb részén „,nagyon jó” körülmények mutatkoznak (6.9. ábra). A későbbi időszakban pedig már csaknem mindegyik járás ilyen viszonyokkal rendelkezhet (6.10. ábra). Júliusban is kedvezőtlen irányú tendencia figyelhető meg, sőt a júniusinál jóval számottevőbb változásra számíthatunk. Az Alföldön megfigyelhető jelenlegi „,ideális” viszonyok megszünnek a század közepére, és a „kitűnő” területek aránya is csökkenést mutat az országban (6.9. ábra). A század végi időszakban pedig további jelentős hanyatlás valószínűsíthető: az ország északi felén „nagyon jónak” minősíthető körülmények jelennek meg, az Alföld nagy részén és a Dunántúl délnyugati részén pedig még egy kategóriával kedvezőtlenebbé válnak a viszonyok (6.10. ábra). Augusztusban is igen kedvezőtlen tendencia figyelhető meg, ugyanis a század közepén a jelenlegi „kitűnő” körülmények helyett az ország nagy részén „nagyon jó” (6.9. ábra), a század végén már csupán ,jó” körülményeket tapasztalhatunk, sőt néhány délnyugati járásban megjelennek az „elfogadhatónak” minősülő viszonyok is (6.10. ábra).

$\mathrm{Az}$ ősz elején, szeptemberben érdemi változás nem várható sem a század közepére (6.9. ábra), sem pedig a század végére (6.10 ábra). Októberben ugyanakkor a klímapotenciál erőteljes javulása valószínűsíthető, s ez jóval számottevőbb, mint bármely tavaszi hónapban. Már a század közepi időszakban is markáns változásnak lehetünk tanúi: az ország nagy részén már „jó” körülmények mutatkoznak, sőt az Alföld egy jelentős része „nagyon jó” minősítésűvé válhat (6.9. ábra). A javuló tendencia folytatódik a század végére is, ráadásul ebben az időszakban már „,kitünő” viszonyok is előtűnnek az Alföld délkeleti részén (6.10. ábra). Novemberben a TCI az ország nagy részén nem vár változást, délnyugaton csökkenhet a „kedvezőtlen” területek aránya (6.9-10. ábra). 

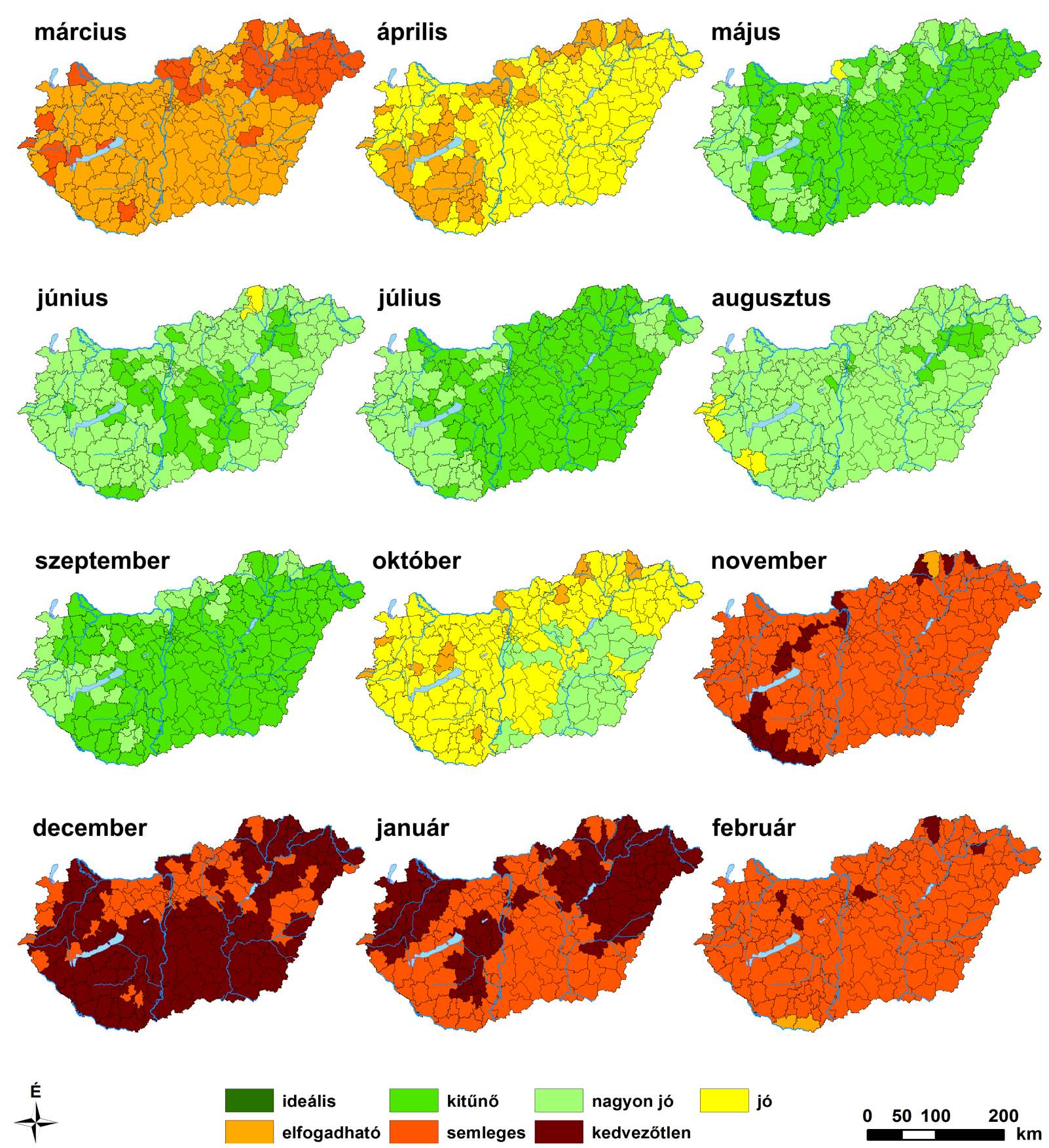

jó

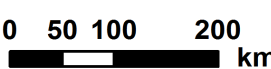

6.9. ábra: A TCI-kategóriák térbeli eloszlása járásonként havi bontásban a 2021-2050 időszakra vonatkozóan

A csak a TCI alapján elemzett téli időszak elején, decemberben több - elsősorban északi járásban már „semleges” viszonyok valószínűsíthetők a jelenlegi „kedvezőtlenek” helyett a század közepén (6.9. ábra), és ennek aránya a későbbi időszakra kissé tovább növekszik (6.10. ábra). Januárban némileg nagyobb mértékü javulás látható, $\mathrm{s}$ az ország több mint felén már „semleges” viszonyok várhatók a század közepére (6.9. ábra), a század végén pedig már csak néhány északi-északkeleti járás maradhat „kedvezőtlennek” minősülő (6.10. ábra). Februárban számottevő változás nem várható, a század közepére kissé csökken a „kedvezőtlen” viszonyok aránya, s csak néhány járás maradhat ilyen minősítésű (6.9. ábra). A század végén is hasonló mintázat mutatkozik, a „kedvezőtlen” körülmények gyakorlatilag megszünnek (6.10. ábra). 

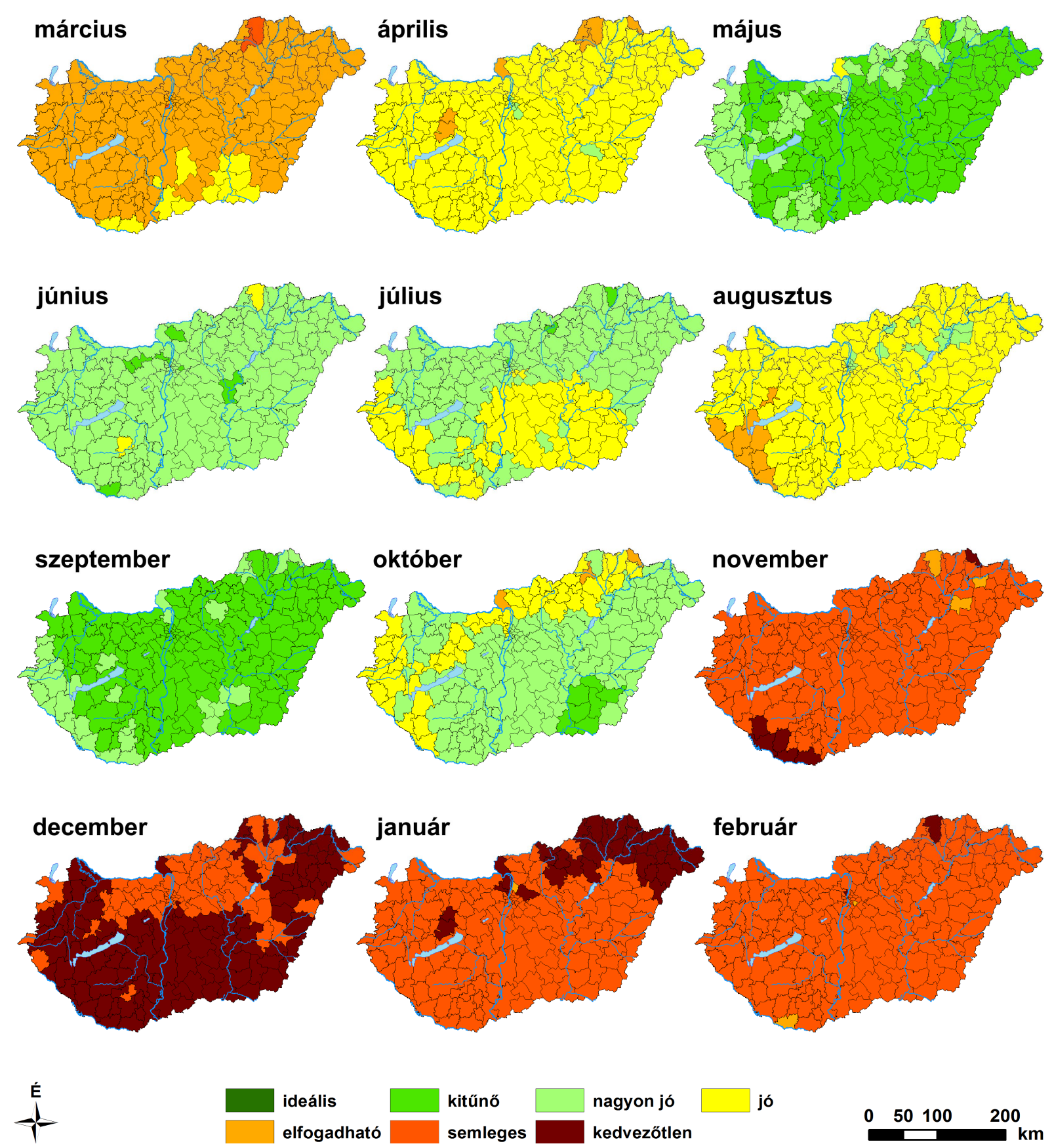

6.10. ábra: A TCI-kategóriák térbeli eloszlása járásonként havi bontásban a 2071-2100 időszakra vonatkozóan

Összegzésként megállapítható, hogy tavasszal változatlanok maradhatnak a turisztikai klimatikus viszonyok, vagy pedig kismértékü (egy kategóriányi) javulásra számíthatunk. Októberben jelentős javulás mutatkozik a TCI mintázata szerint, míg a másik két őszi hónapban nagymértékü változás nem várható. A jelentős turistaforgalommal bíró nyár valamennyi hónapjában kedvezőtlen irányú tendencia figyelhető meg, s a változások júliusban és augusztusban igen nagymértéküek (általában két kategóriányi). Télen kismértékü javulás mutatkozik, amely kedvezhet a szabadtéri aktivitás szempontjából.

Végezetül rátérek az mTCI alakulásában megmutatkozó tendenciák elemzésére, és vázolom, hogy az mTCI-alapú értékelésben milyen fontosabb eltérések figyelhetők meg a TCI mintázatához képest. Tavasszal, márciusban az mTCI mintázata a TCI-hoz hasonlóan javulást jelez, de az ország jelentős részén annál nagyobb mértékben. A század közepén a jelenle- 

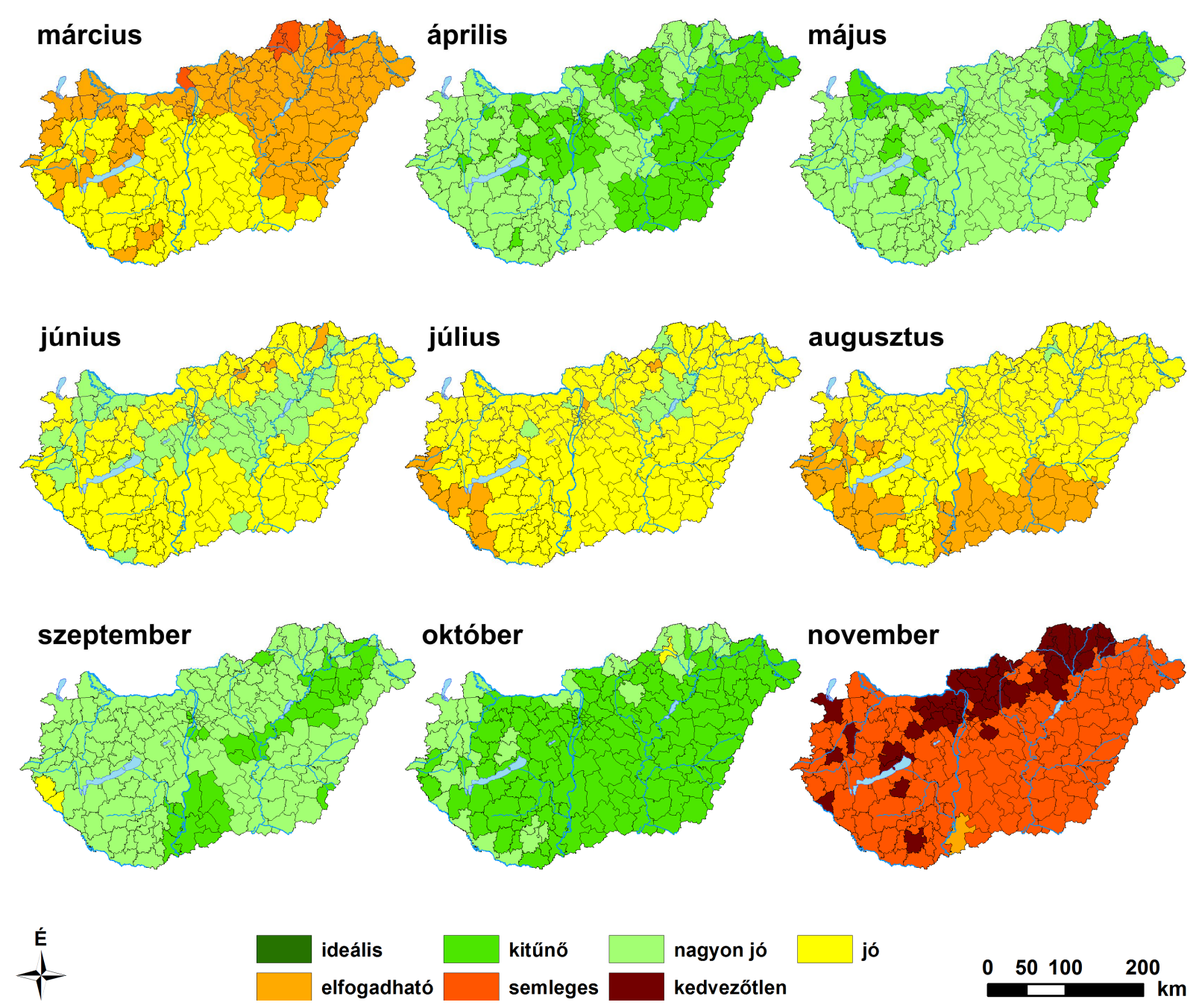

6.11. ábra: Az mTCI-kategóriák térbeli eloszlása járásonként havi bontásban a 2021-2050 időszakra vonatkozóan

gi „elfogadhatónak” minősülő körülmények helyett a Dunántúl és az Alföld nagyobb részén már ,jó” viszonyok valószínűsíthetők (6.11. ábra), a század végén pedig már a „nagyon jó” viszonyok dominálhatnak a déli és nyugati területeken (6.12. ábra). Áprilisban a TCI-hoz hasonlóan egy enyhe javulás várható az mTCI mintázata alapján is. Ekkor a század közepére mindössze egy kismértékü átrendeződés valószínüsíthető (6.11. ábra). Később ugyanakkor az ország nagy területe javulást tapasztalhat, ugyanis a Dunántúlon és az északi járásokban a klímapotenciál az Alföldhöz hasonlóan „kitünő” lehet (6.12. ábra). Májusban a TCI esetével ellentétes tendencia figyelhető meg, ugyanis a klímapotenciál kismértékü romlása mutatkozik. A század közepi időszakra a „kitűnő” területek aránya csökkenést mutat (6.11. ábra), s a század végén már csaknem mindenhol „nagyon jó” körülmények mutatkoznak (6.12. ábra).

A nyár valamennyi hónapjában az mTCI is kedvezőtlen tendenciát mutat, és jelen esetben is júliusban és augusztusban számíthatunk számottevőbb változásra. Júniusban csupán egy enyhébb hanyatlás mutatkozik a korábbi időszakra (a ,jónak" minősülő területek aránya növekszik a „nagyon jó” körülmények rovására) (6.11. ábra), a század végére pedig további jelentős változás már nem várható (6.12. ábra). Július folyamán az mTCI a „nagyon jó” területek arányának csökkenését jelzi a század közepére, így az ország nagy részén a ,jó” viszonyok dominálhatnak, a Dunántúl délnyugati részén pedig megjelenhetnek az „elfogadható- 

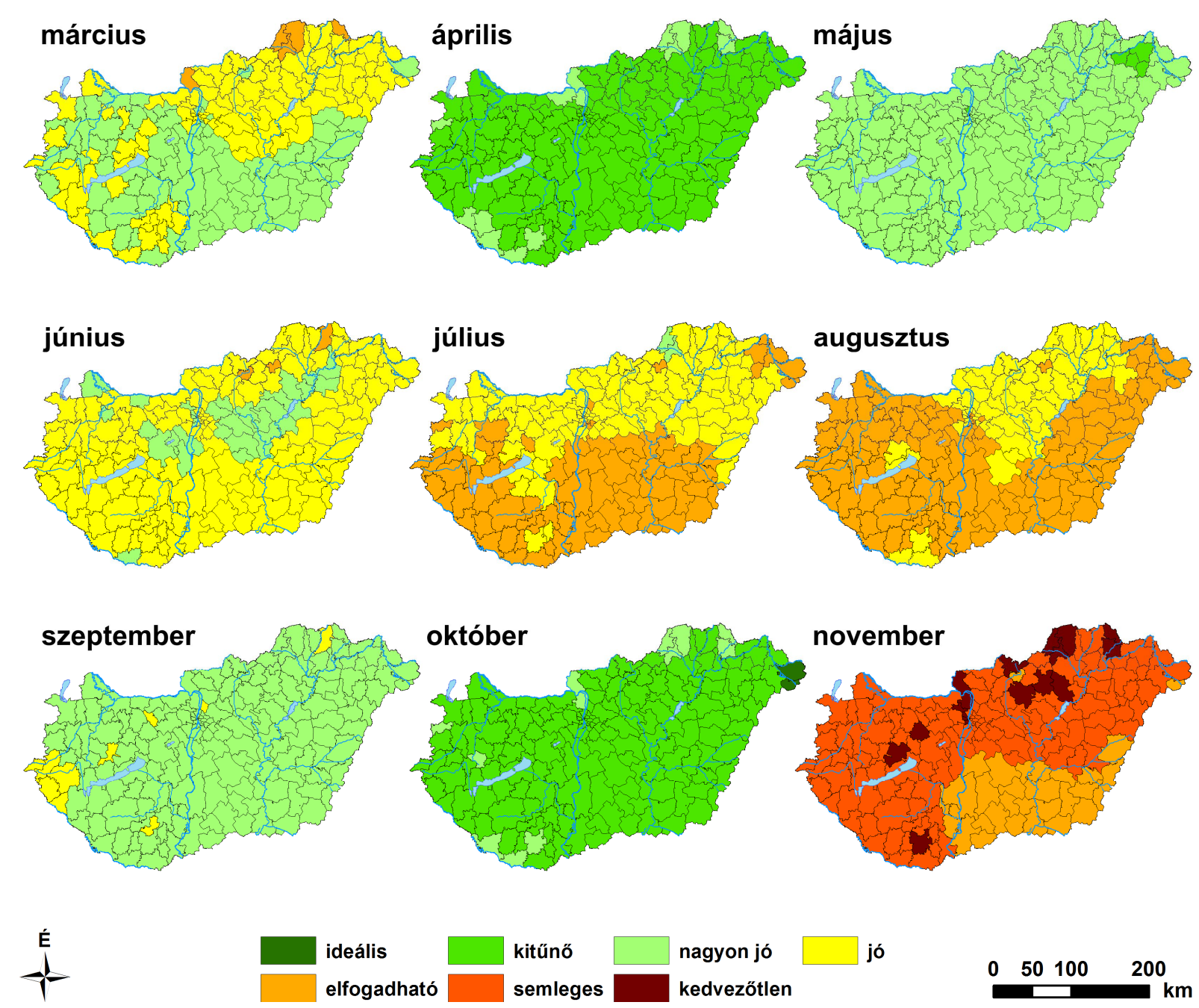

6.12. ábra: Az mTCI-kategóriák térbeli eloszlása járásonként havi bontásban a 2071-2100 időszakra vonatkozóan

nak” minősülő viszonyok is (6.11. ábra). A század végére az mTCI mintázata már „elfogadható" körülményeket jelez az ország körülbelül felén, főként a Délnyugat-Dunántúlon és a Dél-Alföldön (6.12. ábra). Az mTCI-kategóriák térbeli mintázata a század végén hasonlóan alakulhat, mint a TCI-é, viszont egy kategóriával kedvezőtlenebb körülményeket jelez (6.10. és 6.12. ábra). Augusztusban is a júliusihoz hasonló hanyatlás valószínü, a század közepén még csak a Dél-Alföld és néhány délnyugati járás lehet „elfogadható” (6.11. ábra), a század végére már az ország nagyobbik részén ilyen körülmény valószínüsíthető (6.12. ábra).

Ősszel a tavaszhoz hasonlóan nem ekvivalens mindegyik hónapban a várható tendencia. Szeptemberben a májusihoz hasonló változások tapasztalhatók, vagyis kismértékü hanyatlás várható: a „kitűnő” területek megszünnek, az ország nagy része „,nagyon jó” körülményekkel rendelkezhet, s néhány járásban már a ,jó” viszonyok is megjelennek (6.11-12. ábra). Az októberi tendencia viszonylag jól párba állítható az áprilisival, ugyanis a század végére a javulás eredményeként az ország nagy részén már „kitünő” viszonyok lehetnek (6.12. ábra). E pozitív tendencia a TCI esetében is megfigyelhető volt, ám ott jóval nagyobb mértékü változásnak lehettünk tanúi (6.7. és 6.9-10. ábra). Novemberben szintén pozitív tendencia figyelhető meg, ám jelen esetben az mTCI esetében jelentősebb a változás. A század végére a jelenlegi nagy részarányú „kedvezőtlennek” minősülő területek néhány északi járásra szorulnak vissza, a Dél-Alföldön pedig az „elfogadható” viszonyok is megjelennek (6.12. ábra). 


\section{Diszkusszió}

\subsection{Az alkalmazott eszközök értékelése a szakirodalom és saját tapasztalatok tükrében}

Az elmúlt évtizedekben a turizmust befolyásoló éghajlati feltételek jellemzésére többféle értékelő eszközt fejlesztettek ki, az egyszerübb méröszámoktól (pl. TCI) egészen a komplexebb mátrixokig és sémákig (pl. CIT, CTIS) (2.2.4. és 2.3. fejezet). A mutatók felépítésüket és kimeneti formájukat tekintve ugyan jelentősen különböznek egymástól, alkalmazásuk célját és a célközönségüket tekintve szigorú prioritási sorrend nem állítható fel közöttük, sokkal inkább úgy tekinthetők, mint egymás kiegészítői. Ezért egy turisztikai régió klímapotenciáljának komplex értékelését az eszközök együttes használatával célszerü megvalósítani. Egy ilyen átfogó „elemzéscsomag” lehetővé teszi azt is, hogy a szolgáltatók és a turisták kiválaszthassák a céljaikhoz legalkalmasabb módszert, s így a szolgáltatók optimálisabban tudják kialakítani kínálati elemeik körét, a turisták utazással kapcsolatos döntéshozatala pedig megalapozottabb legyen. Ebben a fejezetben saját tapasztalataim és szakirodalmi kutatásaim alapján sorra veszem, hogy a részletesen vizsgált TCI és CTIS eszközök alapvető tulajdonságai hogyan szolgálják azok alkalmazhatóságát a különféle célokra (7.1. táblázat). Az elemzett hazai és külföldi területekre vonatkozó TCI értékelö pontok és CTIS-táblázatok - helyszínenkénti bontásban - megtekinthetők a 6.2., 6.4. és a Függelék 3-11. ábrákon, melyeken jól nyomon követhető az adott terület értékelése a különböző szempontrendszerek szerint.

7.1. táblázat: A Turisztikai klíma index (TCI) és a Klíma-Turizmus-Információs-Rendszer (CTIS) mint egymást kiegészítő értékelő eszközök (Kovács et al. 2016)

\begin{tabular}{lcc}
\hline \multicolumn{1}{c}{ Szempont } & TCI & CTIS \\
\hline Kimenet formája & $\begin{array}{c}\text { egyetlen számérték } \\
\text { (ami al-indexekre } \\
\text { bontható })\end{array}$ & $\begin{array}{c}\text { gyakorisági mátrix bármilyen } \\
\text { (bio)klimatológiai körülményre }\end{array}$ \\
\hline $\begin{array}{l}\text { Releváns új változó hozzáadása / } \\
\text { szükségtelen változó eltávolítása }\end{array}$ & nem lehetséges & lehetséges \\
\hline Térképezés & lehetséges & $\begin{array}{c}\text { nem lehetséges } \\
\text { (javaslatom: kereshető rá megol- } \\
\text { dás, lásd lejjebb) }\end{array}$ \\
\hline Időbeli felbontás módosítása & lehetséges & lehetséges \\
\hline $\begin{array}{l}\text { Komponensek (termikus, fizikai, } \\
\text { esztétikai) módosítása/validálása }\end{array}$ & lehetséges & lehetséges \\
\hline
\end{tabular}

A TCI a turizmus számára releváns klimatológiai változókat súlyozva, additív módon, egyetlen mérőszámba integrálja (2.3.1. fejezet), ami a legkompaktabb és leggyorsabb módja annak, hogy egy terület klimatikus viszonyairól tájékozódni tudjunk (7.1. táblázat). A módszer előnyös lehet azon felhasználók számára, akik nem kívánnak hosszú időt szánni az információszerzésre. A TCI mérőszám jellegéből is következik, hogy könnyedén térképezhető, így egy adott régió viszonyairól átfogó képet tud szolgáltatni, ebből következően kifejezetten jól használható a tájékozódás kezdeti, áttekintő jellegü fázisában. Az indexet széles körben alkalmazzák a jelen és a jövőben várható turisztikai klimatikus viszonyok térképi 
megjelenítésére (pl. Mieczkowski 1985, Scott et al. 2004, Amelung et al. 2007, Farajzadeh and Matzarakis 2009, Perch-Nielsen et al. 2010, Kovács et al. 2017).

Természetesen a TCI számérték volta lehetővé teszi az egyes desztinációk klímapotenciáljának értékelését is (pl. Scott et al. 2004, Amelung and Viner 2006, Németh 2013, Kovács et al. 2016, Roshan et al. 2016a). A kompakt kifejezésmód azonban nem alkalmas arra, hogy külön-külön, részletesen tanulmányozhassuk az egyes klimatológiai körülményekben (pl. csapadékmennyiség, szélsebesség) mutatkozó sajátosságokat. Ráadásul nem biztos, hogy mindegyik paraméter ugyanolyan fontossággal bír a különböző felhasználók számára. Ebből a szempontból kifejezetten előnyös, hogy a TCI számértéke felbontható az alegységeinek ( $C I d, C I a, R, S$ és $W$ ) értékeire, így a felhasználók igényei szerint olyan formába hozható, mely által részletesebben át lehet tekinteni, az egyes tényezők miként járulnak hozzá az általános sajátosságok kialakításához az adott desztinációban (6.2. ábra, Függelék 3.a-11.a. ábra). Szakirodalmi kutatásom során ugyanakkor mindössze Scott and McBoyle (2001), Farajzadeh and Matzarakis (2009) és Whittlesea and Amelung (2010) munkájában találtam erre példát.

Egyes desztinációk részletes vizsgálatára rendeltetésénél fogva alkalmas eszköz a CTIS, amely a relevánsnak ítélt klimatológiai és bioklimatológiai események gyakoriságának ábrázolásán alapul (2.3.3. fejezet). Ebböl kifolyólag ezt az eszközt több tanulmány alkalmasabbnak minősítette a klímapotenciál értékelésére, mint a TCI additív jellegü megközelítését (pl. Matzarakis 2007, 2014, de Freitas et al. 2008, Rutty 2014). A CTIS a kiválasztott események előfordulási valószínűségét egy színkódolt táblázat formájában jeleníti meg. A szoftverben rendelkezésre álló különféle színkódolási opciók lehetővé teszik az összetett információhalmaz könnyebb megértését (2.8., 6.4. ábra, Függelék 3.b-11.b. ábra). Az eszköz lehetővé teszi a felhasználó számára, hogy önmaga döntse el, mely körülménynek szán nagyobb jelentőséget, s melyet tart kevésbé relevánsnak (pl. inkább a napsütés vagy a csapadék mennyisége fontosabb a számára, vagy pedig a termikus körülmények, s azon belül is inkább a hőstresszes vagy pedig a hidegstresszes körülményekre érzékenyebb).

Ehhez a ponthoz kapcsolódóan szót kell ejteni a CTIS-nek arról a további flexibilis tulajdonságáról is, hogy szabadon bele lehet foglalni vagy el lehet hagyni belőle bármilyen éghajlati paramétert, attól függően, hogy mennyire tartja őt a felhasználó relevánsnak az adott területen vagy az egyes turisztikai tevékenységek esetében (Matzarakis 2007, 2014, Lin and Matzarakis 2008, Zaninovic and Matzarakis 2009). A dolgozatban vizsgált helyszínek számára például a sípotenciál vizsgálata egyáltalán nem bír gyakorlati jelentőséggel, így elhagyható az értékelésből. A CTIS-sel ellentétben a TCI esetében nincs lehetőség ily módon figyelembe venni az egyéni igényeket (7.1. táblázat).

A fenti számos pozitív tulajdonság mellett a CTIS egy jelentős gyakorlati hátrányaként ki kell emelni, hogy a TCI-al ellentétben kimenete térképes formában nem jeleníthető meg (Zaninovic and Matzarakis 2009) (7.1. táblázat). Személyes tapasztalataim alapján azonban úgy vélem, hogy a TCI alkalmazásainak analógiájára a CTIS esetében is elérhető többféle felhasználási terület, csak ez esetben éppen az ellenkező irányból kell elindulni a továbbfejlesztéshez. Míg a TCI esetében az alapvetően kompakt, térképi ábrázolásra alkalmas indexet (pl. 6.7. ábra) al-indexeire bontva használhatjuk különböző desztinációk részletező, összehasonlító vizsgálatára (pl. 6.2. ábra), a CTIS sokrétü információi is összevonhatók lehetnek néhány vagy csupán egyetlen számértékbe. Például az egyes klimatológiai eseményekhez tartozó gyakorisági cellaértékeket súlyozhatjuk a jövőben aszerint, hogy az adott célközönség 
egy bizonyos tevékenység esetében mennyire tartja fontosnak az adott körülményt. A súlyozott cellaértékek természetesen ezután is konvertálhatóak lehetnek például az „ideálistól” a „kedvezőtlen” minősítésig terjedő diszkrét kategóriákra. Ezek alapján megalkotható egy a TCI al-indexekhez hasonló ábrázolási forma (6.2. ábra, Függelék 3.a-11.a. ábra), melyen a különböző tényezők (pl. a neutrálisnak érzett körülmények) előfordulásának súlyozott gyakorisága szerepelne. Sőt, további összevonásokkal desztinációnként akár egyetlen számértékig is eljuthatunk, amely azután alkalmas lehet olyasfajta áttekintő, regionális térképezésre, melyet a TCI esetében bemutattam (pl. 6.7. ábra). Bizonyos személyiségtípus számára előnyösebb lehet ez a fajta megjelenítés a CTIS-táblázat aprólékos tanulmányozásához képest. Az említett súlyértékek hiteles meghatározásához természetesen egy hosszú távú kérdőíves felmérés kivitelezése lenne szükséges.

A vizsgált eszközök időbeli felbontásának tekintetében elmondható, hogy a CTIS bázisát általában tíznapos (dekádos) gyakoriságok alkotják, és megjelenítése is tíznapos intervallumonként történik (havi bontású használatát mindössze Endler et al. 2010, Ketterer and Matzarakis 2010, valamint Farajzadeh and Matzarakis 2012 tanulmányában azonosítottam). Munkám során jómagam is tíznapos megjelenítést alkalmaztam a turisztikai célterületek értékeléséhez. A dekádos ábrázolást azért tartottam fontosnak, mert sokkal közelebb áll egy átlagos üdülés tipikus időtartamához, és így jobban igazodik a felhasználók igényeihez, mint a havi megjelenítés (3.1. fejezet). Az időbeli felbontása miatt a TCI-t gyakran kritika éri (3.1. fejezet). Szakirodalmi kutatásaim során - Perch-Nielsen et al. (2010) munkájának kivételével - jómagam is csak olyan tanulmányokat azonosítottam, melyekben a TCI-számítás alapját havi meteorológiai adatok képezték, és a TCI-eredményeket havi bontásban jelenítették meg. Munkámban bizonyítottam, hogy a TCI esetén is finomítható az időbeli felbontás, és dekádos átlagokat képezve tíznapi bontásban jelenítettem meg eredményeimet, mely összhangban van a CTIS-el (6.1.1. fejezet). Meglátásom szerint Mieczkowski (1985) értékelő pontrendszereinek változatlan formájú használata - az időbeli felbontás tekintetében - helyénvalónak tekinthető a dekádos átlagok képezésekor is. A csapadék al-index esetében viszont mindenképpen szükséges volt az értékelő pontrendszerben alkalmazott módosítás, mivel ez a tag a csapadék összmennyiségén alapul, melynek minősítéséhez természetesen más és más küszöbértékek szükségesek az időbeli léptéktől függően (4.2.1. fejezet). A TCI-t alkalmazó szakirodalomban csupán Perch-Nielsen et al. (2010) munkájában találkoztam havi bontásnál finomabb alkalmazással. A tanulmányban a szerzők napi meteorológiai adatokból indultak ki, az eredményeket pedig vagy havi TCI-átlagok formájában jelenítették meg, vagy a napi TCI-értékeket kategorizálták, s havi bontásban vizsgálták annak alakulását (pl. január folyamán az „elfogadhatónak" minősülő napok számát). Összegzésként megállapítható, hogy mindkét értékelő eszköz lehetővé teszi az időbeli felbontás módosítását (7.1. táblázat), amelyre természetesen kitüntetett figyelemmel kell lenni az átlagok és a gyakoriságok képezésekor, és a TCI csapadékértékelö pontrendszerének alkalmazásakor.

Mindkét módszer alkalmas arra, hogy a helyi lakossághoz vagy a turistákhoz adaptáljuk őket, figyelembe véve a szubjektív reakcióikat adott tevékenységek esetében (7.1. táblázat). E folyamat a TCI esetében új értékelő pontrendszerek, a CTIS kapcsán pedig új kategóriahatárok és/vagy küszöbértékek felállítását igényli az egyes komponensekre vonatkozóan. Mivel a dolgozat egyik legfontosabb célját a TCI és a CTIS magyar lakossághoz való adaptálása jelentette, a következő alfejezetben áttekintem az adaptálás és a véghezvitt módszertani fejlesztés újszerűségét, valamint azok nemzetközi alkalmazási lehetőségét. 


\subsection{A módszertani fejlesztés és az adaptálás értékelése, valamint nemzetközi alkalmaz- hatóságuk}

Munkám során a TCI és a CTIS termikus komponenseit vetettem vizsgálat alá. Ez a TCI esetében a nappali komfortindex (CId) és a napi komfortindex (CIa) tagokat, míg a CTIS esetében a termikus stressztől mentes, a höstresszes, valamint a hidegstresszel rendelkező körülményeket jelentette. A TCI termikus al-indexeit egyrészt módszertanilag fejlesztettem, másrészt a hazai lakosokhoz igazítottam. A munka gyakorlatilag két nagyobb lépést foglalt magában: (i) a PET integrálását a termikus al-indexekbe, valamint (ii) egy olyan PET-alapú értékelő pontrendszer kidolgozását, mely a hazai lakosság hőérzetében megnyilvánuló sajátosságokat tükrözi. A CTIS kapcsán a végrehajtott feladat némileg egyszerübb volt, mivel a termikus komponensei már eleve a PET-indexen alapulnak. Így csupán egy bizonyos populációhoz, illetve tevékenységformához - jelen esetben a magyar lakosokhoz és a városi turizmus körébe eső aktivitásformákhoz - történő adaptálást kellett megvalósítani a PETküszöbértékek módosítása által. Az új PET-határértékek definiálása után pedig a magyar lakosság által neutrálisnak, hüvös-hidegnek és meleg-forrónak érzett termikus viszonyok gyakoriságait kellett meghatároznom.

A TCI-t, illetve bármely komponensét tudomásom szerint mind ez idáig nem kísérelték meg adaptálni adott populációhoz. A TCI-tagok elméleti korszerúsítése kapcsán meg kell említeni, hogy az effektív hőmérséklet helyett néhány tanulmány az ún. „látszólagos hőmérsékletet" (Apparent Temperature - AT, Steadman 1979, 1984) alkalmazta (Scott and McBoyle 2001, Scott et al. 2004, Amelung 2006, Amelung and Viner 2006, Perch-Nielsen et al. 2010). Az idézett tanulmányok - Amelung (2006) kivételével - az AT használatának tényét pusztán megemlítik, annak módszertanáról - például hogy milyen összefüggést és értékelő pontrendszert használtak - viszont nem szólnak. Amelung (2006) ugyanakkor közölte az általa használt AT-formulát, és megemlítette, hogy a Mieczkowski (1985)-féle ET értékelő pontokat változatlan formában használta az AT-értékek minősítésére is. A Steadman (1984) által megalkotott négy összefüggés közül - feltehetöen az egyszerüsége folytán - a beltérre kifejlesztett ATváltozatot használta, amely pusztán a léghőmérsékleten és a gőznyomáson alapul, s így mai tudásunk szerint már korszerütlennek számít. Az általam alkalmazott PET-index minőségi javulást hoz a TCI számára, mivel a PET valamennyi termofiziológiailag releváns tényező hatását figyelembe veszi $(2.2 .4$, 3.1. és 4.1.1. fejezet).

A nemzetközi szakirodalomban több példa is azonosítható, hogy az egyes PETtartományokhoz új küszöbértékeket rendelnek hozzá egy adott klimatikus adottságú területen élö populáció szubjektív reakcióinak felhasználásával (Függelék 1. táblázat). (A szubjektív reakció ez esetben általában kérdőíves formában felmért hőérzet vagy pedig a termikus viszonyokkal kapcsolatos elégedettség/elégedetlenség aránya a lakosság körében.) A PETkategóriahatárokat a helyi lakosok szubjektív reakciói alapján újraskálázták például Tajvan (Lin and Matzarakis 2008), Szingapúr és Délkelet-Kína (Yang et al. 2013b), Észak-Kína (Lai et al. 2014), valamint Izrael területére (Cohen et al. 2013, Pearlmutter et al. 2014) (Függelék 1. táblázat). Szakirodalmi áttekintésem alapján ugyanakkor a turisztikai klimatikus viszonyok jellemzésére mind ez idáig csak Lin and Matzarakis (2008) alkalmazott helyi lakosokhoz adaptált küszöbértékeket. A tanulmányban - a munkámhoz hasonlóan - a CTIS termikus komponenseiben a helyi (tajvani) lakosság szubjektív reakcióihoz igazított PETküszöbértékeket használtak. Az új kategóriahatárokat kérdőíves úton gyüjtött adatokból vezet- 
ték le, de nem hőérzetadatból (TSV vs. PET függvénykapcsolatból) kiindulva, hanem a lakosok termikus viszonyokkal kapcsolatos elégedettségét/elégedetlenségét felmérő kérdésre alapozva (melynek százalékos arányát ábrázolták a PET függvényében). A kategóriahatárok levezetése ugyanakkor teljes mértékben önkényes volt: adatesztétikai okokból a 88\%-os elégedettségi arány jelölte ki a stresszmentes kategóriát $\left(26-30{ }^{\circ} \mathrm{C}\right)$, majd pedig ugyancsak önkényesen 4-4 ${ }^{\circ} \mathrm{C}$-onként jelölték ki mindkét irányban az egyes hőérzeti kategóriahatárokat ( $\mathrm{pl}$. az „enyhén hüvös” kategóriát a $22-26{ }^{\circ} \mathrm{C}-\mathrm{os}$, az ,enyhén meleget” pedig a $30-34{ }^{\circ} \mathrm{C}$-os tartomány adta). További problémákat fedeztem fel a nomenklatúra szintjén is, ugyanis a levezetett szubjektív elégedettséget/elégedetlenséget tükröző PET-kategóriákra időnként mint termikus stressz-, időnként mint hőérzeti kategóriák hivatkoznak. A CTIS-be foglalt új küszöbértékek esetén pedig következetesen stresszkategóriákat említenek (pl. hidegstressz, hőstressz). Mindkettő elnevezés helytelen.

Munkám során a TCI és a CTIS termikus tagjainak adaptálását a magyar lakosság szabadtéri (városi környezetbeli) hőérzeti mintázatainak figyelembevételével végeztem el, mégpedig évszakosan differenciálva. Az adaptálás azonban más földrajzi környezetben (más klímazónán) élő populációkra és természetesen más tevékenységformákra is kiterjeszthetők, figyelembe véve a helyi klimatikus körülményekhez alkalmazkodott lakosság szubjektív reakcióit. A módszerek egy kiterjedt adatbázis létrehozását igénylik, amely hosszú távú, szabadtéren kivitelezett humánkomfort-felmérés segítségével valósítható meg, kérdőíves interjúk és párhuzamos meteorológiai mérések útján. A vizsgálat kiterjeszthető bármelyik évszakra vagy akár a teljes évre, amennyiben az az adott területen releváns. Egy következő vizsgálati lépés lehet - melyet a szegedi adatbázis egyelőre nem tett lehetővé - a fenti módszertant alapul véve hiteles TCI-pontrendszerek és CTIS-küszöbértékek felállítása az éghajlat fizikai (pl. csapadék, szélsebesség) és esztétikai (pl. napsütés) aspektusaira.

A közelmúltban Tajvanon kidolgoztak egy új, kétlépcsős módszertant az éghajlati körülményekkel való elégedettség értékelésére („Customized rating assessment of climate suitability” - CRACS, Lin et al. 2015). E módszertan úgyszintén alkalmazható az éghajlat mindhárom aspektusára és nemzetközi szinten kiterjeszthető, amennyiben rendelkezésre áll hozzá komplex meteorológiai mérésekből és kérdőíves eredményekből álló adatbázis. A legfontosabb újítás a turisztikai klimatológiai szakirodalom tükrében annak kihangsúlyozása, hogy a klíma valamennyi aspektusának értékelését egy adott népcsoport (pl. a tajvani lakosság) szubjektív reakcióihoz szükséges igazítani. Az idézett tanulmány módszertanának első lépcsője az ún. „személyre szabott elégedettséget” értékelő rész, melyben egy adott területen a releváns termikus, fizikai és esztétikai jellegü éghajlati eseményekre a helyi lakosok szubjektív reakcióin alapuló küszöbértékeket kell meghatározni, majd a gyakoriságokat egy adott időbeli bontásban (pl. dekádok) a CTIS-hez hasonló táblázatos formában ábrázolni. A szerzők hangsúlyozzák, hogy amennyiben az adatbázis nagysága és minősége lehetővé teszi, a statisztikai analízis előtt célszerü a mintát kettébontani, mégpedig az egyes éghajlati körülményekkel kapcsolatos preferenciák alapján. Például külön meg kell határozni a meleget és a hűvöset preferáló csoportokhoz tartozó küszöbértékeket, vagy szintén felbontható az adott minta a napsütést kedvelö, valamint a felhősebb viszonyokat preferáló alcsoportokra is. A táblázatos megjelenítést célszerü az adott preferencia vonatkozásában a terhelőbb (kellemetlenebb) körülményekre elvégezni, mert ennek ismerete az adott egyén számára nagyobb információtartalommal bír (pl. a hűvösebb körülményeket kedvelők számára a hőstressz, a túl magas hőmérséklet, a túl magas napfénytartam mint kellemetlen viszonyok gyakoriságát meghatározni és 
szemléltetni). A CRACS másik blokkja az első részre épül, és az éghajlati viszonyokkal kapcsolatos általános elégedettséget értékeli egy adott területen élő népcsoport esetében. A végeredmény ebben az esetben egy-egy százalékban kifejezett elégedettségi arány mindegyik időszakra, amely együttesen tükrözi a populáció valamennyi körülménnyel kapcsolatos elégedettségét. Minél nagyobb a számérték, annál nagyobb az elégedetlenek aránya, így egyre kevésbé tekinthető komfortosnak az adott időszak.

A munkámban bemutatott, helyi lakosokra (jelen esetben a magyar emberekre) adaptált TCI és CTIS eszközök alkalmazásával lehetőség nyílik rá, hogy a különböző területek klímapotenciálját az odautazó, az otthoni klimatikus körülményekhez szokott lakosság szemszögéböl elemezhessük. Az adaptált eszközök információt nyújthatnak a turisták számára oly módon, hogy - jelen esetben - a höérzetükkel kapcsolatos jellemzőiket alapul véve kiválaszthatják a számukra legkedvezőbb utazási időszakot és célterületet. Ilyen megfontolásból néhány példát mutattam be a TCI, az mTCI és a CTIS alkalmazására, melyhez hazai és külföldi turisztikai desztinációk éghajlati adatait, valamint rácspontokra vonatkozó mérési és klímamodelladatokat használtam fel (6. fejezet). Az értékelések minden esetben könnyed szabadtéri tevékenységekre vonatkoznak, mint például városnézés, vásárlás, látnivalók meglátogatása. Más tevékenységek (pl. tengerparti turizmus) esetében az adott cselekményben részt vevő látogatók értékeléséről kell információval rendelkeznünk, mivel ez a különböző tevékenységet folytatók esetében jelentősen eltérhet.

\subsection{Az alkalmazási példák értékelése a szakirodalom és a gyakorlati szféra tükrében}

Az alkalmazási példák eredményeivel (6. fejezet) kapcsolatban szükségesnek (és a turisztikai klimatológia szakirodalmának szintjén hiánypótlónak) tartom, hogy nemzetközi viszonylatban is tárgyaljam az egyes megállapításokat. Az adaptált eszközök esetében (mTCI és a CTIS módosított része) természetesen erre nincs lehetőségem, így gyakorlatilag az eredeti TCI-t, valamint a CTIS bizonyos komponenseit lehetne összevetni a szakirodalmi eredményekkel. Ez irányú törekvéseim során azonban számos problémába ütköztem, melyek nemcsak megnehezítik, hanem sok esetben ésszerütlen feladattá is teszik az eredmények összevetését a korábban publikált eredményekkel. Ez nemcsak a saját munkám vonatkozásában, hanem gyakorlatilag valamennyi irodalom összevetésével kapcsolatban is érvényes. A hiteles összevethetőséget egyfelől akadályozza a turisztikai klimatológiai mutatók meghatározásához használt kiindulási adatbázisok eltérése (alapadatok, modellek, vizsgálati időszakok), másrészt a sokrétü adatfeldolgozási és -elemzési módszer, valamint az eredmények eltérő megjelenítése (térképezés, skálázás, különböző időbeli lépték). Sok esetben az alapinformációk hiányossága is nehezíti az összehasonlítást. Mivel az alkalmazási eredményeim nemzetközi példákkal való direkt összevetése szakmailag kifogásolható lenne, csupán bizonyos tendenciákra fókuszálok, és csak az eredeti TCI-ra szorítkozom e fejezetben.

Eredményeim alapján a jelenlegi klimatikus viszonyok között vitathatatlanul a nyár rendelkezik a legkedvezőbb turisztikai klimatikus körülményekkel („,nyári csúcs”), és a tél mutatkozik a legkedvezőtlenebbnek, mind a vizsgált hazai és európai célterületek (6.1. és 6.3.a., c., e. ábra), mind a teljes hazai viszonyok esetében (6.7. ábra). E megállapítás összhangban van az évszakos TCI-viszonyokat is taglaló európai és észak-amerikai tanulmányokkal (Scott and McBoyle 2001, Scott et al. 2004, Amelung and Viner 2006, Hein et al. 2009, PerchNielsen et al. 2010, Németh 2013). A Madrid és Szaloniki térségére kapott enyhén bimodális 
évi menet (6.3.e. ábra) sem meglepő annak fényében, hogy a nyári csúccsal jellemezhető európai és amerikai térségektől délre övezetes elterülésben rendre bimodális jellegü városokat vagy területeket találunk (Scott and McBoyle 2001, Scott et al. 2004, Amelung and Viner 2006, Hein et al. 2009, Perch-Nielsen et al. 2010). A vizsgált tanulmányok közül Amelung and Viner (2006), valamint Perch-Nielsen et al. (2010) már kifejezetten a mediterrán térség bizonyos területeire (pl. spanyol félsziget) is kimutatott egy enyhén bimodális évi menetet. Madrid és Szaloniki térségére az északabbi területekhez képest csaknem egész évben kedvezöbb viszonyokat kaptam (6.3.a., c., e. ábra), ami úgyszintén jól illeszkedik az Európában megfigyelt övezetes eloszlású abszolút TCI-tendenciákhoz (Amelung et al. 2007, Hein et al. 2009, Perch-Nielsen et al. 2010, Amelung and Moreno 2012).

A jövőben várható viszonyok tekintetében az európai és észak-amerikai tanulmányok hasonló álláspontot képviselnek (2.2.2. fejezet), amely szerint az övezetesen elterülö nyári csúcsú és bimodális területek várhatóan északabbra húzódnak a jövőben. Ez maga után vonja azt, hogy Európában a déli területek (mediterrán térség) jelenlegi nyári csúccsal (vagy esetleg még csak nagyon enyhén bimodális viszonyokkal) rendelkező területei egyre erőteljesebben bimodálissá válhatnak. Évszakos szinten ez azt jelenti, hogy a jelenleg nyáron igazán kiválónak (s Európában az egyik legkedvezőbbnek) mutatkozó mediterrán térségben éppen a fö turistaszezont képező nyári időszakban erőteljes visszaesés várható. Ezzel szemben az átmeneti évszakokban és esetleg télen kedvezőbb körülmények adódhatnak. Az észak-európai és északamerikai területeken viszont éppen nyáron számíthatunk javulásra, amely több vizsgálat szerint a tavasz és az ősz jelentős hányadára is kitolódhat (Scott and McBoyle 2001, Scott et al. 2004, Amelung and Viner 2006, Amelung et al. 2007, Nicholls and Amelung 2008, Hein et al. 2009, Perch-Nielsen et al. 2010, Amelung and Moreno 2012). Megemlítem, hogy egy-egy pesszimistább forgatókönyvvel végzett modellkísérlet a század végére már egyes északeurópai és észak-amerikai területeken is a nyári körülmények kismértékü hanyatlását jelzi (nyári csúcsból átmenet egy enyhe bimodális szerkezetbe) (Scott and McBoyle 2001, Scott et al. 2004, Nicholls and Amelung 2008, Perch-Nielsen et al. 2010). A magyar körülményekre kapott, jövőbeli TCI-viszonyokat taglaló eredményeim ismét jól illeszkednek az európai és észak-amerikai tendenciákhoz (6.9-10. ábra). Hazánk a földrajzi elhelyezkedéséből adódóan egyfajta átmenetet képezhet az északi és a déli területeken mutatkozó évszakos tendenciák között. Eredményeim szerint hazánkban a 21. század folyamán télen, tavasszal és ősszel változatlanok maradhatnak a viszonyok, vagy kisebb-nagyobb mértékü javulás várható. E tendencia megegyezik az Európa és Észak-Amerika középső területein megfigyelhető eredményekkel az említett három évszakban. A hazánkban a nyári időszakban mutatkozó jelentős visszaesés szintén összhangban van a szakirodalommal, ugyanis a mediterrán térségben mutatkozó erőteljes negatív tendencia - általában kisebb mértékben - még hazánk tágabb térségében is megjelenik (Amelung and Viner 2006, Amelung et al. 2007, Hein et al. 2009, Amelung and Moreno 2012, Perch-Nielsen et al. 2010).

A jövőre vonatkozó saját következtetéseim és szakirodalmi eredmények értékelése és összevetése során szem előtt kell tartani azt is, hogy azok csupán egy-egy lehetséges forgatókönyvet jelentenek, s nem a várható viszonyok biztos előrejelzéseként szolgálnak. A klímamodellekre alapozott projekciók ugyanis minden esetben bizonytalansággal terheltek, ami az éghajlat természetes változékonyságából és a modellbe foglalt fizikai folyamatok közelítő jellegü leírásából ered. Emellett nem rendelkezünk biztos információval arra vonatkozóan sem, hogy az éghajlati rendszerre hatással bíró társadalmi-gazdasági folyamatok a jövőben 
hogyan alakulhatnak. A jövőbeli éghajlati viszonyok (és hatások) megismeréséhez figyelembe kell venni a projekciók (és hatásvizsgálatok) bizonytalanságait, melyek számszerüsítését több modellre és forgatókönyvre alapozva lehet megtenni. E módszer biztosíthatja, hogy kiegyensúlyozottan megjelenjenek a különböző forgatókönyvek megválasztásából, a regionális klímamodellek eltéréseiből vagy a regionális modellek számára határfeltételt szolgáltató globális klímamodellekből származó bizonytalanságok. Egy optimális szimulációegyüttes legalább 810 körültekintően kiválasztott tagot tartalmaz (Szépszó et al. 2016).

A 4.2.2. fejezetben ismertettem, hogy a KRITéR projekt keretében született eredményeim (6.7-12. ábra) egyetlen forgatókönyvre (SRES A1B) végrehajtott egyetlen modellkísérleten (Aladin-Climate 4.5) alapulnak. Ebből kifolyólag az eredmények nem adnak lehetőséget a projekciókban megjelenő bizonytalanságok számszerüsítésére. További munkám során minőségi előrelépést jelenthet egy jól összeválogatott szimulációegyüttes (ensemble) alkalmazása, többféle forgatókönyvön alapulva, többféle regionális modellel végrehajtva, melyeket különböző globális modellek hajtanak meg. Az éghajlati forgatókönyveket tekintve a SRESszcenáriók mellett az IPCC legújabb, RCP (Representative Concentration Pathways, Moss et al. 2010) forgatókönyveit is szükséges bekapcsolni a vizsgálatokba.

Mindazonáltal a TCI és az mTCI meghatározásához kialakított módszertan, valamint az mTCI kapcsán végrehajtott fejlesztések egy megfelelő kezdeti lépést jelentenek abban az irányban, hogy segítsük az éghajlatváltozás hatásaihoz való alkalmazkodást és az ezzel kapcsolatos szakpolitikai tervezést és döntéshozatalt. A döntéshozók és az éghajlati információk egyéb felhasználóinak informálásával segítséget nyújthatunk a turisztikai szolgáltatások fejlesztéséhez, ami végső soron gyakorlati segítséget jelent a fenntartható turizmusfejlesztés megteremtése érdekében.

A módszertani értékelések és azok fejlesztése mellett a KRITéR projekt egyik eddig nem említett célja volt az eredmények nyilvános keretek közé helyezése. A Magyar Földtani és Geofizikai Intézet munkatársai az elmúlt években kifejlesztették a Nemzeti Alkalmazkodási Térinformatikai Rendszer (NATéR) elnevezésű multifunkciós rendszert, amelynek célja, hogy elősegítse a klímaváltozás hatásaihoz való alkalmazkodást szolgáló jogalkotást, stratégiaépítést és a szükséges intézkedések megalapozását Magyarországon (Orosz 2016). A NATéR számára számos szakterület képviselői állították elő adatrétegeiket az elmúlt néhány év folyamán (pl. hidrológia, mezőgazdaság, társadalomföldrajz). Jelen eredményeim, valamint a CIT-indexre kapott eredmények térképes formában 2016 májusától elérhetőek (NATéR 2016). A fent említett elvek - több szimulációra és forgatókönyvre alapozott modellkísérletek - mentén már körvonalazódik a NATéR-nek jelenleg alapot adó adatrendszer továbbfejlesztése. 


\section{8. Összefoglalás}

Doktori értekezésem zárásaként összegzem munkám fontosabb eredményeit és következtetéseit az 1. fejezetben kitüzött általános célok, illetve a 3.4. fejezetben részletezett célkitüzések alapján.

I. Hiányosságokat és egyéb problémákat azonosítottam a turisztikai klímát értékelő TCI és CTIS felépítésével és hitelességével kapcsolatban a nemzetközi szakirodalom és saját tapasztalataim alapján (Kovács and Unger 2014a, 2014b, Kovács et al. 2014, 2016, 2017).

1. A módszerek kritikai vizsgálata révén megállapítottam, hogy a TCI jelenlegi időbeli felbontása elégtelen, a termikus komponensei (nappali és napi komfortindex) mai tudásunk szerint már korszerütlennek számítanak, továbbá valamennyi komponensének értékelő pontrendszerei, valamint az al-indexek súlyozása alapvetően önkényes. A CTIS esetében megállapítottam, hogy az általánosan alkalmazott értéktartományok és küszöbértékek nem tükrözik a helyi lakosság szubjektív reakcióit (3.1. fejezet).

2. Rámutattam, hogy mivel a termikus környezet értékelése erősen szubjektív folyamat, szükséges és hiánypótló feladat a termikus komfortindexek, valamint a turisztikai klíma értékelésére használatos módszertan (skála, pontrendszer, küszöbértékek) hitelesítése a helyi lakosság vagy a turisták tényleges reakciói alapján (3.2. fejezet).

II. Továbbfejlesztettem a TCI módszertanát, valamint a magyar lakosság termikus viszonyokkal kapcsolatos szubjektív értékeléséhez adaptáltam a TCI-t és a CTIS-t (Kovács and Unger 2014a, 2014b, Kovács et al. 2014, 2016, 2017, Kántor et al. 2016a).

3. Módosítottam a TCI felépítését és struktúráját.

a. Korszerüsítettem a TCI termikus komponenseit: módszertani fejlesztést dolgoztam ki, mellyel a PET-index integrálható a TCI eredeti termikus komponensei helyére (3.1. és 4.1.2. fejezet).

b. Finomítottam a TCI időbeli felbontását: tíznapos időbeli rendszert javasoltam és alakítottam ki, s ehhez kapcsolódóan módosítottam a csapadék al-index értékelö pontrendszerét (3.1. és 4.2.1. fejezet).

4. Meghatároztam a magyar lakosok termikus környezetre adott szubjektív reakcióinak évszakos mintázatát. Megállapítottam, hogy az alanyok a melegebb termikus viszonyokkal szemben mindegyik vizsgált évszakban toleránsabbak, mint a hideg termikus viszonyokkal kapcsolatban. A PET-ben kifejezett neutrális hőmérséklet szezonális trendje (tavasz ősz < nyár) rámutat a magyar lakosság évközi klimatikus adaptációs folyamataira. Az eredeti PET-értéktartományokhoz képest jelentős eltéréseket fedeztem fel, melyek közül kiemelendő a magyar lakosok fokozott toleranciája a melegebb termikus viszonyokkal szemben az átmeneti évszakokban (4.1. és 5.2. fejezet). 
5. A magyar lakosokhoz igazítottam a TCI termikus komponenseit: új értékelő pontrendszert alakítottam ki a magyar lakosság tényleges, évszakonként változó szubjektív reakciói alapján (3.1., 4.1.2. és 5.3. fejezet).

6. A magyar lakosokhoz igazítottam a CTIS termikus komponenseit: új, évszakos PET-értéktartományokat határoltam le a hazai lakosság hőérzeti mintázatai alapján, majd a magyar lakosok által neutrálisnak, melegnek és hidegnek érzett zónákat (PET-küszöbértékeket) új termikus komponensekként integráltam a CTISalapú értékelésbe (3.1., 4.1.2. és 5.3. fejezet).

III. Értékeltem néhány kiemelt hazai és európai turisztikai célterület jelenlegi klímapotenciálját a TCI, az mTCI és a CTIS alapján (Kovács and Unger 2014a, 2014b, Kovács et al. 2016).

7. Kimutattam, hogy a TCI évi eloszlása jelentősen eltér az mTCI-hoz képest. A TCI esetében a kedvezőtlenebb téli viszonyok után tavasszal intenzív javulás figyelhető meg, s a legkedvezőbb körülmények a hazai területeken májustól szeptemberig, az északi régiókban júniustól augusztusig detektálhatók. Ezután az ősz folyamán a körülmények gyors ütemben hanyatlanak. Az évi eloszlás így egy „nyári csúcshoz" hasonló szerkezetet vesz fel. Ezzel szemben az mTCI esetében az eloszlás „bimodális”: a legoptimálisabb klíma a tavasz és az ősz egy részében (általában április és szeptember-október környékén) mutatkozik, nyáron pedig jelentősen kedvezőtlenebbek a körülmények. A dél-európai régiókban a TCI eloszlása alapján egy enyhe, az mTCI esetében viszont egy erőteljes „bimodális” szerkezetet kaptam (6.1.1. fejezet).

8. A TCI és az mTCI al-indexekre bontása révén kimutattam, hogy elsősorban a $C I d / m C I d$ tag felelős a két index különböző futású évi meneteiért és a vizsgált területek közötti jelentős különbségekért. Ehhez gyakran a többi tag ( $C I a / m C I a, R$, $S, W)$ hatása is hozzájárul kisebb mértékben (6.1.1. fejezet).

9. Mind az mTCI, mind a CTIS alapján elvégzett értékelések azt mutatják, hogy valamennyi vizsgált területen alapvetően az átmeneti évszakok a legalkalmasabb időszakok szabadtéri városi tevékenységekre. Az mTCI évi eloszlása ugyanis mindegyik területen erőteljesen „,bimodális”. A CTIS-alapú komplex értékelés eredményeként pedig alátámasztottam, hogy a hazai területeken és az északi régiókban leginkább a május és a szeptember mutatkozik kedvezőnek, sőt az utóbbi területeken a nyári dekádokban is viszonylag kellemesen alakulnak a termikus körülmények. A dél-európai régiókban szintén az átmeneti évszakok - különösen az április és az október - ajánlhatók szabadtéri tevékenységekre. Kimutattam azt is, hogy a fenti képet a csapadék árnyalhatja, mivel éppen a kedvezőnek minősíthető időszakokban nagyobb valószínüséggel számíthatunk rá (6.1.1. és 6.1.2. fejezet).

\section{Elemeztem Magyarország jövőben várható turisztikai klímapotenciálját a TCI és az mTCI alapján (Kovács et al. 2017).}

10. A jelen klímát tükröző mérési eredmények alapján kimutattam, hogy mind a TCI, mind az mTCI évi alakulása visszatükrözi a turisztikai célterületek adott indexszel végzett értékelésénél megfigyelt tendenciákat. A TCI-értékelés szerint ugyanis télre kaptam a legkedvezőtlenebb viszonyokat, májustól szeptemberig viszont ked- 
vező feltételek mutatkoznak. Az eredmények jelen esetben is azt jelzik, hogy a kedvezőtlen téli viszonyok után tavasszal intenzíven javulnak a körülmények, május és szeptember között hozzávetőlegesen változatlan körülmények, majd az ősz folyamán nagymértékü visszaesés jellemző. Az mTCI esetében - amelynél a téli hónapok elemzését kihagytam - a legkedvezőtlenebb hónapok a november és a március. A tavasz folyamán jelen esetben is jelentős javulás, júniustól szeptemberig viszont egy enyhe visszaesés figyelhető meg. Ezután ismét javulás, majd viszszaesés történik az ősz végéig (6.1.1. és 6.2.1. fejezet).

11. Kimutattam, hogy a TCI és az mTCI nyárra megegyező, tavaszra és őszre hasonló tendenciát jelez a 21. század végéig. Mindkét index alapján kedvezőtlen változás várható a nyár összes hónapjára, ami júliusban és augusztusban igen nagymértékü (1-3 kategóriányi). Tavasszal a TCI szerint változatlan vagy kissé (1 kategóriával) javuló viszonyokra számíthatunk. Az mTCI márciusban jelentős javulást, áprilisban változatlan vagy kissé javuló viszonyokat, májusban viszont a TCI-al ellentétben az ország nagyobb részén 1 kategóriányi visszaesést jelez. Összel szintén nem ekvivalens a tendencia iránya mindegyik hónapban. A TCI alapján szeptemberben változatlan, októberben jelentősen javuló, novemberben változatlan vagy néhol 1 kategóriával javuló viszonyok várhatók. Az mTCI szeptemberben a májushoz hasonlóan általában 1 kategóriányi visszaesést, októberben a TCI-hoz hasonlóan javulást, novemberben pedig szinte mindenhol 1 kategóriányi javulást mutat (6.2.2. fejezet). 


\section{Köszönetnyilvánítás}

Köszönettel tartozom témavezetőmnek, DR. UNGER JÁNOS tanszékvezető egyetemi tanárnak, hogy megteremtette kutatásom feltételeit, koordinálta munkámat és előrehaladásomat, valamint számos hasznos tanáccsal és észrevétellel látott el. Hálás köszönetemet fejezem ki témavezetőmnek, DR. KÁNTOR NOÉMI tudományos munkatársnak, aki időt és energiát nem kímélve segítette munkám elörehaladását és eredményeim létrejöttét. Megköszönöm a számos szakmai tanácsát, ötletét, melyet kamatoztatni tudtam munkám során.

Hálával tartozom TAKÁCS ÁGNES doktorjelöltnek a közös munkáért, segítségeiért, és hogy mindig mindenben számíthattam rá. Megköszönöm MuCSINÉ DR. ÉGERHÁZI LILLA munkáját, akivel úgyszintén nagyon sokat dolgoztam együtt. Hálás vagyok LERNERNÉ LELOVICS ENIKÖNEK is a segítségeiért.

Köszönöm az Éghajlattani és Tájföldrajzi Tanszék munkatársainak és PhD-hallgatóinak: Dr. GulyÁs ÁGNeSNEK, DR. TANÁCs EsZTERNEK, Dr. GÁl TAMÁSNAK, SKARBit NÓRÁNAK, GYÖRI ZSUZSÁNAK, KisS MÁRTONNAK és MOLNÁR GERGÖNEK, hogy az utolsó percekig támogattak és biztattak. Külön köszönöm DR. KEVEINÉ DR. BÁRÁNY ILONA professzor asszony szavait, aki lelkesedésével és biztatásával sokszor elősegítette, hogy átlendüljek a mélypontokon.

Ezúton is köszönetet mondok mindazon kollégának és hallgatónak, akik valamely terepi mérésben vagy adat-elöállításban részt vettek. Sokat jelentett több szakdolgozónak is a munkája, akik révén nem egyszer tudtam újat tanulni.

Megköszönöm NÉMETH ÁKOSNAK, az Országos Meteorológiai Szolgálat éghajlati szakértöjének munkáját, akivel a kezdetek óta töretlen lelkesedéssel dolgozunk együtt. Köszönetemet fejezem ki továbbá az Országos Meteorológiai Szolgálat ÉGHaJlati OszTÁlya valamennyi munkatársának a közös munkákért, valamint számos meteorológiai és éghajlati adat rendelkezésemre bocsátásáért. Megköszönöm DR. FORMAN BALÁzSNAK, a Budapesti Corvinus Egyetem egyetemi docensének munkáját.

Hálával tartozom Dr. GÁl CSILLÁNAK, DR. TANÁCS ESZTERNEK és NŐVÉREMNEK az angol nyelvi lektorálásokért.

Mindent köszönök CSALÁDOMNAK és BARÁTAIMNAK! 


\section{Irodalomjegyzék}

Abegg B (1996): Klimaänderung und Tourismus - Klimafolgenforschung am Beispiel des Wintertourismus in den Schweizer Alpen. Schlussbericht NFP 31, Zürich

Ali-Toudert F (2005): Dependence of outdoor thermal comfort on street design in hot and dry climate. Ber Meteor Inst Albert-Ludwigs-Univ Freiburg 15, $224 \mathrm{p}$

Ali-Toudert F, Mayer H (2006): Numerical study on the effects of aspect ratio and orientation of an urban street canyon on outdoor thermal comfort in hot and dry climate. Build Environ 41, 94-108

Amelung B (2006): Global (environmental) change and tourism. Issues of scale and distribution. PhD Dissertation, Universitaire Pers Maastricht. Amelung Publishers, Maastricht.

https://cris.maastrichtuniversity.nl/portal/files/1730329/guid-02675359-b867-453b-be8b-64fbba24c6aeASSET1.0

Amelung B, Viner D (2006): Mediterranean tourism: exploring the future with the tourism climatic index. $J$ Sustain Tour 14, 349-366

Amelung B, Nicholls S, Viner D (2007): Implications of global climate change for tourism flows and seasonality. $J$ Travel Res 45, 285-296

Amelung B, Moreno A (2012): Costing the impact of climate change on tourism in Europe: results of the PESETA project. Climatic Change 112, 83-100

Amelung B, Nicholls S (2014): Implications of climate change for tourism in Australia. Tourism Manage 41, 228-244

Amengual A, Homar V, Romero R, Alonso S, Ramis C (2012): Projections of the climate potential for tourism at local scales: application to Platja de Palma, Spain. Int J Climatol 32, 2095-2107

Andrade H, Vieira R (2007): A climatic study of an urban green space: The Gulbenkian park in Lisbon (Portugal). Finisterra 42, 27-46

ASHRAE (1974): Handbook of fundamentals. American Society of Heating, Refrigerating and Air-Conditioning Engineers Inc., New York

ASHRAE (2001): Chapter 14 - Measurement and instruments. In: ASHRAE Handbook: Fundamentals. American Society of Heating, Refrigerating and Air-Conditioning Engineers Inc., Atlanta, 14.28-14.29

ASHRAE (2004): ANSI/ASHRAE Standard 55-2004. Thermal environmental conditions for human occupancy. American Society of Heating, Refrigerating and Air-Conditioning Engineers Inc., Atlanta

Auliciems A, Szokolay SV (2007): Thermal comfort. PLEA Note 3, Passive and Low Energy Architecture International, Department of Architecture, The University of Queensland, Brisbane.

http://me.emu.edu.tr/hacisevki/MENG443\%20PPT1B.pdf

Aynsley RM, Szokolay SV (1998): Options for assessment of thermal comfort/discomfort for aggregation into NatHERS star ratings. Report of James Cook University, Townsville.

http://www.envirosustain.com.au/page18.php

Bafaluy D, Amengual A, Romero R, Homar V (2014): Present and future climate resources for various types of tourism in the Bay of Palma, Spain. Reg Environ Change 14, 1995-2006

Bartholy J, Mészáros R, Geresdi I, Matyasovszky I, Pongrácz R, Weidinger T (2013): Meteorológiai alapismeretek. Eötvös Loránd Tudományegyetem, Budapest. http://elte.prompt.hu/sites/default/files/tananyagok/MeteorologiaAlapismeretek/book.pdf

Bartholy J, Pongrácz R, Pieczka I (2014): How the climate will change in this century? Hung Geogr Bull 63, 55-67

Basarin B, Lukic T, Matzarakis A (2016): Quantification and assessment of heat and cold waves in Novi Sad, Northern Serbia. Int J Biometeorol 60, 139-150

Becker S, Potchter O, Yaakov Y (2003): Calculated and observed human thermal sensation in an extremely hot and dry climate. Energ Buildings 35, 747-756

Belda M, Skalák P, Farda A, Halenka T, Déqué M, Csima G, Bartholy J, Torma Cs, Boroneant C, Caian M, Spiridonov $V$ (2015): CECILIA regional climate simulations for future climate: Analysis of climate change signal. Adv Meteorol 2015, Article ID: 354727

Bernecker P (1962): Grundlagenlehre des Fremdenverkehrs. Österreichischer Gewerbeverlag, Wien

Besancenot J-P (1990): Climat et tourisme (Collection geographie). Masson, Paris 
Brosy C, Zaninovic K, Matzarakis A (2014): Quantification of climate tourism potential of Croatia based on measured data and regional modeling. Int J Biometeorol 58, 1369-1381

Caliskan O, Cicek I, Matzarakis A (2012): The climate and bioclimate of Bursa (Turkey) from the perspective of tourism. Theor Appl Climatol 107, 417-425

Charalampopoulos I, Tsiros I, Chronopoulou-Sereli A, Matzarakis A (2013): Analysis of thermal bioclimate in various urban configurations in Athens, Greece. Urban Ecosyst 16, 217-233

Chen L, Wen Y, Zhang L, Xiang WN (2015): Studies of thermal comfort and space use in an urban park square in cool and cold seasons in Shanghai. Build Environ 94, 644-653

Cheng $\mathrm{V}, \mathrm{Ng}$ E, Chan C, Givoni B (2012): Outdoor thermal comfort study in a sub-tropical climate: a longitudinal study based in Hong Kong. Int J Biometeorol 56, 43-56

Cohen P, Potchter O, Matzarakis A (2013): Human thermal perception of coastal Mediterranean outdoor urban environments. Appl Geogr 37, 1-10

Crompton JL (1979): Motivations for pleasure vacation. Ann Tourism Res 6, 408-424

Csete M, Pálvölgyi T, Szendrö G (2013): Assessment of climate change vulnerability of tourism in Hungary. Reg Environ Change 13, 1043-1057

Csima G, Horányi A (2008): Validation of the ALADIN-Climate regional climate model at the Hungarian Meteorological Service. Idöjárás 112, 155-177

Csorvási A, Illy T, Sábitz J, Szabó P, Szépszó G, Zsebeházi G (2016): A jövőre vonatkozó projekciók eredményeinek együttes kiértékelése, bizonytalanságok számszerüsítése. Beszámoló tanulmány, „A sugárzási kényszer változásán alapuló új éghajlati szcenáriók a Kárpát-medence térségére (RCMTéR)” projekt, Országos Meteorológiai Szolgálat, Budapest. http://www.met.hu/RCMTeR/hu/publikacio/

Dann GMS (1977): Anomie, ego-enhancement and tourism. Ann Tourism Res 4, 184-194

Davis NE (1968): An optimum summer weather. Weather 23, 305-317

Dávid L, Jancsik A, Rátz T (2007): Turisztikai erőforrások. A természeti és kulturális erőforrások turisztikai hasznosítása. 2. kiadás. Perfekt Gazdasági Tanácsadó, Oktató és Kiadó Zrt., Budapest

de Freitas CR (1985): Assessment of human bioclimate based on thermal response. Int J Biometeorol 29, $97-$ 119

de Freitas CR (1990): Recreation climate assessment. Int J Climatol 10, 89-103

de Freitas CR (2003): Tourism climatology: evaluating environmental information for decision making and business planning in the recreation and tourism sector. Int J Biometeorol 48, 45-54

de Freitas CR, Scott D, McBoyle G (2008): A second generation climate index for tourism (CIT): specification and verification. Int J Biometeorol 52, 399-407

de Freitas $C R$ (2015): Weather and place-based human behavior: recreational preferences and sensitivity. Int $J$ Biometeorol 59, 55-63

Dixon JC, Prior MJ (1987): Wind-chill indices - a review. Meteorol Mag 116, 1-17

Endler C, Oehler K, Matzarakis A (2010): Vertical gradient of climate change and climate tourism conditions in the Black Forest. Int J Biometeorol 54, 45-61

Eugenio-Martin JL, Campos-Soria JA (2010): Climate in the region of origin and destination choice in outbound tourism demand. Tourism Manage 31, 744-753

Égerházi LA, Kovács A, Unger J (2013a): Application of microclimate modelling and onsite survey in planning practice related to an urban micro environment. Adv Meteorol 2013, Article ID: 251586

Égerházi LA, Kovács A, Kántor N, Unger J (2013b): Examination of the simulated thermal conditions in a popular playground related to the human reactions and the judgment of the area design. In: Pandi G, Moldovan F (szerk): Air and water components of the environment. Babeș-Bolyai University, Cluj-Napoca, 277-284

Égerházi LA (2014): Városi közterületek komplex humán-bioklimatológiai értékelése és annak várostervezési vonatkozásai szegedi példák alapján. Doktori értekezés. Földtudományok Doktori Iskola, Szegedi Tudományegyetem, Szeged. http://doktori.bibl.u-szeged.hu/2223/

Égerházi LA, Kovács A, Takács Á, Égerházi L (2014): Comparison of the results of two micrometeorological models and measurements. Acta Clim Chorol Univ Szegediensis 47-48, 33-42

Fagence M, Kevan S (1998): Migration, recreation and tourism: Human responses to climate differences. In: Auliciems A, de Dear R, Fagence M, Kolkstein LS, Kevan SD, Szokolay SV, Webb AR (szerk): Advances in Bioclimatology 5. Springer-Verlag Berlin Heidelberg, 133-160

Fanger PO (1972): Thermal comfort. McGraw-Hill Book Co, New York 
Farajzadeh H, Matzarakis A (2009): Quantification of climate for tourism in the northwest of Iran. Meteorol Appl 16, 545-555

Farajzadeh H, Matzarakis A (2012): Evaluation of thermal comfort conditions in Ourmieh Lake, Iran. Theor Appl Climatol 107, 451-459

Fountain ME, Arens E, Xu T, Bauman FS, Oguru M (1999): An investigation of thermal comfort at high humidities. ASHRAE Trans 105, 94-103

Fröhlich D, Matzarakis A (2013): Modeling of changes in thermal bioclimate: examples based on urban spaces in Freiburg, Germany. Theor Appl Climatol 111, 547-558

Gagge AP, Stolwijk JAJ, Nishi Y (1971): An effective temperature scale based on a simple model of human physiological regulatory response. ASHRAE Trans 77, 247-262

Getz D, Nilsson PA (2004): Responses of family businesses to extreme seasonality in demand: the case of Bornholm, Denmark. Tourism Manage 25, 17-30

Giannaros TM, Melas D, Matzarakis A (2015): Evaluation of thermal bioclimate based on observational data and numerical simulations: an application to Greece. Int J Biometeorol 59, 151-164

Gómez Martín B (2004): An evaluation of the tourist potential of the climate in Catalonia (Spain): A regional study. Geogr Ann 86, 249-264

Gómez Martín B (2005): Weather, climate and tourism. A geographical perspective. Ann Tourism Res 32, 571591

Gómez Martín B (2006): Climate potential and tourist demand in Catalonia (Spain) during the summer season. Climate Res 32, 75-87

Gössling S, Bredberg M, Randow A, Sandström E, Svensson P (2006): Tourist perceptions of climate change: A study of international tourists in Zanzibar. Curr Issues Tourism 9, 419-435

Gössling S, Scott D, Hall CM, Ceron J-P, Dubois G (2012): Consumer behaviour and demand response of tourists to climate change. Ann Tourism Res 39, 36-58

Gulyás Á, Unger J, Matzarakis A (2006): Assessment of the microclimatic and human comfort conditions in a complex urban environment: modelling and measurements. Build Environ 41, 1713-1722

Gulyás Á, Matzarakis A, Unger J (2010): Comparison of the urban-rural comfort sensation in a city with warm continental climate. In: Matzarakis A, Mayer H, Chmielewski F-M (szerk): Proceedings of the 7th Conference on Biometeorology. Ber Meteor Inst Albert-Ludwigs-Univ Freiburg 20, 473-478

Hamilton JM, Lau MA (2005). The role of climate information in tourist destination choice decision-making. In: Gössling S, Hall CM (szerk): Tourism and Global Environmental Change. Routledge, London

Hamilton JM, Maddison DJ, Tol RSJ (2005): Climate change and international tourism: A simulation study. Global Environ Change 15, 253-266

Havenith $G$ (2005): Temperature regulation, heat balance and climatic stress. In: Kirch W, Bertollini R, Menne B (szerk): Extreme weather events and public health responses. Springer-Verlag Berlin Heidelberg, 69-80

Hawkins Ed, Osborne TM, Ho CK, Challinor AJ (2013): Calibration and bias correction of climate projections for crop modelling: An idealised case study over Europe. Agr Forest Meteorol 170, 19-31

Hein L, Metzger MJ, Moreno A (2009): Potential impacts of climate change on tourism; a case study for Spain. Curr Opin Environ Sustain 1, 170-178

Higham J, Hinch T (2002): Tourism, sport and seasons: the challenges and potential of overcoming seasonality in the sport and tourism sectors. Tourism Manage 23, 175-185

Houghten FC, Yaglou CP (1923): Determining equal comfort lines. J Am Soc Heat Vent Eng 29, 165-176

Hódos R (2014): A turisztikai klímapotenciál alakulása a Kárpát-régióban 1961-2010 között. BSc szakdolgozat. Eötvös Loránd Tudományegyetem, Budapest.

http://nimbus.elte.hu/tanszek/docs/BSc/2014/HodosRita_2014.pdf

Höppe P (1992): Ein neues Verfahren zur Bestimmung der mittleren Strahlungstemperatur im Freien [A new method to determine the mean radiant temperature outdoors]. Wetter und Leben 44, 147-151

Höppe P (1993): Heat balance modelling. Experientia 49, 741-746

Höppe $P$ (1999): The physiological equivalent temperature - a universal index for the biometeorological assessment of the thermal environment. Int $J$ Biometeorol 43, 71-75

Hübner A, Gössling S (2012): Tourist perceptions of extreme weather events in Martinique. J Destin Mark Manage 1, 47-55

Hwang R-L, Lin T-P (2007): Thermal comfort requirements for occupants of semi-outdoor and outdoor environments in hot-humid regions. Architect Sci Rev 50, 357-364 
IPCC (2014a): Annex II: Glossary [Mach KJ, Planton S, von Stechow C (szerk)]. In: Climate Change 2014: Synthesis Report. Contribution of Working Groups I, II and III to the Fifth Assessment Report of the Intergovernmental Panel on Climate Change [(Core Writing Team, Pachauri RK, Meyer LA (szerk)]. IPCC, Geneva, 117-130. https://www.ipcc.ch/pdf/assessment-report/ar5/syr/SYR_AR5_FINAL_full.pdf

IPCC (2014b): Climate Change 2014: Synthesis Report. Summary for Policymakers. Contribution of Working Groups I, II and III to the Fifth Assessment Report of the Intergovernmental Panel on Climate Change [Core Writing Team, Pachauri RK, Meyer LA (szerk)]. IPCC, Geneva. https://www.ipcc.ch/pdf/assessmentreport/ar5/syr/AR5_SYR_FINAL_SPM.pdf

IPCC (2014c): Climate Change 2014: Impacts, Adaptation, and Vulnerability. Part A: Global and Sectoral Aspects. Contribution of Working Group II to the Fifth Assessment Report of the Intergovernmental Panel on Climate Change [Field CB, Barros VR, Dokken DJ, Mach KJ, Mastrandrea MD, Bilir TE, Chatterjee M, Ebi KL, Estrada YO, Genova RC, Girma B, Kissel ES, Levy AN, MacCracken S, Mastrandrea PR, White LL (szerk)]. Cambridge University Press, Cambridge, United Kingdom and New York, NY, USA. https://www.ipcc.ch/pdf/assessment-report/ar5/wg2/WGIIAR5-PartA_FINAL.pdf

Jang $S$ (2004): Mitigating tourism seasonality: A quantitative approach. Ann Tourism Res 31, 819-836

Jendritzky $G$ (1993): The atmospheric environment - an introduction. Experientia 49, 733-738

Kahulits L, Kemény E, Bódi E, Nagy A (1997): Bevezetés a közgazdaságtanba I. Alapfogalmak és mikroökonómia. Tankönyv távoktatás célra. Pénzügyi és Számviteli Föiskola, Budapest

Kántor N, Unger $J$ (2010): Benefits and opportunities of adopting GIS in thermal comfort studies in resting places: An urban park as an example. Landscape Urban Plan 98, 36-46

Kántor N, Unger $J$ (2011): The most problematic variable in the course of human biometeorological comfort assessment - the mean radiant temperature. Cent Eur J Geosci 3, 90-100

Kántor N, Égerházi LA, Gulyás Á (2011a): Assessments of the outdoor thermal conditions in Szeged, Hungary: perceptions and preferences of local individuals. In: Gerdes A, Kottmeier C, Wagner A (szerk): Climate and Constructions Int Conf Karlsruher Institut für Technologie, Karlsruhe, 307-314

Kántor N, Gulyás Á, Égerházi LA, Unger J (2011b): Assessment of the outdoor thermal conditions in Szeged, Hungary: thermal sensation ranges for local residents. In: Gerdes A, Kottmeier C, Wagner A (szerk): Climate and Constructions Int Conf Karlsruher Institut für Technologie, Karlsruhe, 181-190

Kántor N (2012): Városi közterületek termikus komfortviszonyainak értékelése Szeged példáján különös tekintettel a látogatók szubjektív reakcióira. Doktori értekezés. Környezettudományi Doktori Iskola, Szegedi Tudományegyetem, Szeged. http://doktori.bibl.u-szeged.hu/1450/

Kántor N, Égerházi LA, Unger J (2012): Subjective estimation of thermal environment in recreational urban spaces - part 1: investigations in Szeged, Hungary. Int J Biometeorol 56, 1075-1088

Kántor N, Kovács A, Lin T-P (2015): Looking for simple correction functions between the mean radiant temperature from the 'standard black globe' and the 'six-directional' techniques in Taiwan. Theor Appl Climatol $121,99-111$

Kántor $N$ (2016): Differences between the evaluation of thermal environment in shaded and sunny position. Hung Geogr Bull 65, 139-153

Kántor N, Kovács A, Takács Á (2016a): Seasonal differences in the subjective assessment of outdoor thermal conditions and the impact of analysis techniques on the obtained results. Int J Biometeorol 60, 1615-1635

Kántor N, Kovács A, Takács Á (2016b): Small-scale human-biometeorological impacts of shading by a large tree. Open Geosci 8, 231-245

Ketterer C, Matzarakis A (2010): The tourism climate of Engadin, Switzerland. In: Matzarakis A, Mayer H, Chmielewski F-M (szerk): Proceed 7th Conf on Biometeorology. Ber Meteor Inst Albert-Ludwigs-Univ Freiburg 20, 398-403

Knez I, Thorsson $S$ (2006): Influences of culture and environmental attitude on thermal, emotional and perceptual evaluations of a public square. Int $J$ Biometeorol 50, 258-268

Knez I, Thorsson S (2008): Thermal, emotional and perceptual evaluations of a park: Cross-cultural and environmental attitude comparisons. Build Environ 43, 1483-1490

Kovats RS, Valentini R, Bouwer LM, Georgopoulou E, Jacob D, Martin E, Rounsevell M, Soussana J-F (2014): Europe. In: Climate Change 2014: Impacts, Adaptation, and Vulnerability. Part B: Regional Aspects. Contribution of Working Group II to the Fifth Assessment Report of the Intergovernmental Panel on Climate Change [Barros VR, Field CB, Dokken DJ, Mastrandrea MD, Mach KJ, Bilir TE, Chatterjee M, Ebi KL, Est- 
rada YO, Genova RC, Girma B, Kissel ES, Levy AN, MacCracken S, Mastrandrea PR, White LL (szerk)]. Cambridge University Press, Cambridge, United Kingdom and New York, NY, USA, 1267-1326.

https://www.ipcc.ch/pdf/assessment-report/ar5/wg2/WGIIAR5-Chap23_FINAL.pdf

Kovács A, Németh Á (2012): Tendencies and differences in human thermal comfort in distinct urban areas in Budapest, Hungary. Acta Clim Chorol Univ Szegediensis 46, 115-124

Kovács A, Unger J (2013): A turizmus klíma index első módosítása a közép-európai viszonyokhoz - példák. In: Németh Á (szerk): Orvosmeteorológiai Konferencia - 2013 Konferenciakötet. MMT-MBE-MHT, Budapest, $36-50$

Kovács A, Unger J (2014a): Modification of the Tourism Climatic Index to Central European climatic conditions - examples. Idöjárás 118, 147-166

Kovács A, Unger J (2014b): Analysis of tourism climatic conditions in Hungary considering the subjective thermal sensation characteristics of the south-Hungarian residents. Acta Clim Chorol Univ Szegediensis 47-48, $77-84$

Kovács A, Unger $J$ (2014c): A turizmus klíma index módosítási lehetősége a közép-európai klimatikus viszonyokhoz. Légkör 59, 78-85

Kovács A, Kántor N, Égerházi LA (2014): Assessment of thermal sensation of residents in the Southern Great Plain, Hungary. In: Pandi G, Moldovan F (szerk): Air and water components of the environment. BabeșBolyai University, Cluj-Napoca, 354-361

Kovács A, Unger J, Szépszó G (2015): Adjustment of tourism climatological indicators for the Hungarian population in assessing exposure and vulnerability to climate change. In: Demiroğlu OC, de Freitas CR, Scott D, Kurnaz ML, Ünalan D (szerk): Proceed 4th Int Conf on Climate, Tourism and Recreation - CCTR2015. Istanbul Policy Center, Istanbul, 71-76

Kovács A, Unger J, Gál CV, Kántor N (2016): Adjustment of the thermal component of two tourism climatological assessment tools using thermal perception and preference surveys from Hungary. Theor Appl Climatol 125, 113-130

Kovács A, Németh Á, Unger J, Kántor N (2017): Tourism climatic conditions of Hungary - present situation and assessment of future changes. Idöjárás 121, in press

Kozak M (2002): Comparative analysis of tourist motivations by nationality and destinations. Tourism Manage 23, 221-232

KRITéR (2015): „A klímaváltozás okozta sérülékenység vizsgálata, különös tekintettel a turizmusra és a kritikus infrastruktúrákra" projekt. http://www.met.hu/KRITeR/hu/kezdo/index.php

Krüger EL, Rossi FA (2011): Effect of personal and microclimatic variables on observed thermal sensation from a field study in southern Brazil. Build Environ 46, 690-697

Krüger EL, Drach P, Emmanuel R, Corbella $O$ (2013): Assessment of daytime outdoor comfort levels in and outside the urban area of Glasgow, UK. Int J Biometeorol 57, 521-533

Krüzselyi I, Bartholy J, Horányi A, Pieczka I, Pongrácz R, Szabó P, Szépszó G, Torma Cs (2011): The future climate characteristics of the Carpathian Basin based on a regional climate model mini-ensemble. $A d v S c i$ Res 6, 69-73

KSH (2016): Jelentés a turizmus és vendéglátás éves teljesítményéről, 2015. Központi Statisztikai Hivatal, Budapest. http://www.ksh.hu/docs/hun/xftp/idoszaki/jeltur/jeltur15.pdf

KSH (2017): Turizmus-szatellitszámlák, 2013. Központi Statisztikai Hivatal, Budapest. http://www.ksh.hu/docs/hun/xftp/idoszaki/turizmszatt/turizmszat13.pdf

Lai D, Guo D, Hou Y, Lin C, Chen Q (2014): Studies of outdoor thermal comfort in northern China. Build Environ $77,110-118$

Lelovics E, Unger J, Gál T, Gál CV (2014): Design of an urban monitoring network based on Local Climate Zone mapping and temperature pattern modelling. Climate Res 60, 51-62

Lengyel M (1986): A turizmus állandó és új tényezői, valamint motivációi (A turizmus új megközelítése). Doktori Értekezés, Budapest

Lengyel M (2004): A turizmus általános elmélete. Kereskedelmi és Idegenforgalmi Továbbképző Kft., Budapest

Lin T-P, Matzarakis A (2008): Tourism climate and thermal comfort in Sun Moon Lake, Taiwan. Int J Biometeorol 52, 281-290

Lin T-P (2009): Thermal perception, adaptation and attendance in a public square in hot and humid regions. Build Environ 44, 2017-2026 
Lin T-P, de Dear R, Hwang R-L (2011): Effect of thermal adaptation on seasonal outdoor thermal comfort. Int $J$ Climatol 31, 302-312

Lin T-P, Yang S-R, Matzarakis A (2015): Customized rating assessment of climate suitability (CRACS): climate satisfaction evaluation based on subjective perception. Int J Biometeorol 59, 1825-1837

Lindner-Cendrowska K (2013): Assessment of bioclimatic conditions in cities for tourism and recreational purposes (a Warsaw case study). Geogr Pol 86, 55-66

Lindner-Cendrowska K, Blazejczyk K (2016): Impact of selected personal factors on seasonal variability of recreationist weather perceptions and preferences in Warsaw (Poland). Int J Biometeorol. doi: 10.1007/s00484016-1220-1

Lohmann M, Kaim E (1999): Weather and holiday destination preferences image, attitude and experience. Tourism Rev 54, 54-64

Mahmoud AHA (2011): Analysis of the microclimatic and human comfort conditions in an urban park in hot and arid regions. Build Environ 46, 2641-2656

Mailly D, Abi-Zeid I, Pepin S (2014): A multi-criteria classification approach for identifying favourable climates for tourism. J Multi-Crit Decis Anal 21, 65-75

Mansfeld Y, Freundlich A, Kutiel H (2007): The relationship between weather conditions and tourists' perceptions of comfort: the case of the winter sun resort of Eilat. In: Amelung B, Blazejczyk K, Matzarakis A (szerk): Climate change and tourism - assessment and coping strategies. Institute of Geography and Spatial Organization PAS, Maastricht, 116-139

Masterton JM, Richardson FA (1979): Humidex: A method of quantifying human discomfort due to excessive heat and humidity. Atmospheric Environment Service, Environment Canada, Downsview, Ontario

Matzarakis A, Mayer H (1996): Another kind of environmental stress: thermal stress. WHO Newsl 18, 7-10

Matzarakis A, Mayer H, Iziomon MG (1999): Application of a universal thermal index: physiological equivalent temperature. Int J Biometeorol 43, 76-84

Matzarakis A (2006): Weather- and climate-related information for tourism. Tour Hosp Plan Dev 3, 99-115

Matzarakis A (2007): Assessment method for climate and tourism based on daily data. In: Matzarakis A, de Freitas $C R$, Scott D (szerk): Developments in tourism climatology. International Society of Biometeorology, Commission on Climate, Tourism and Recreation, Freiburg, 52-58

Matzarakis A, Rutz F, Mayer H (2007): Modelling radiation fluxes in simple and complex environments - application of the RayMan model. Int J Biometeorol 51, 323-334

Matzarakis A, Endler C (2010): Climate change and thermal bioclimate in cities: impacts and options for adaptation in Freiburg, Germany. Int J Biometeorol 54, 479-483

Matzarakis A, Rutz F, Mayer H (2010a): Modelling radiation fluxes in simple and complex environments: basics of the RayMan model. Int J Biometeorol 54, 131-139

Matzarakis A, Rudel E, Zygmuntowski M, Koch E (2010b): Bioclimatic maps for tourism purposes. Phys Chem Earth 35, 57-62

Matzarakis A, Schneevoigt T, Matuschek O, Endler C (2010c): Transfer of climate information for tourism and recreation - the CTIS software. In: Matzarakis A, Mayer H, Chmielewski F-M (szerk): Proceed 7th Conf on Biometeorology. Ber Meteor Inst Albert-Ludwigs-Univ Freiburg 20, 392-397

Matzarakis A, Hammerle M, Koch E, Rudel E (2012): The climate tourism potential of Alpine destinations using the example of Sonnblick, Rauris and Salzburg. Theor Appl Climatol 110, 645-658

Matzarakis A, Rammelberg J, Junk J (2013): Assessment of thermal bioclimate and tourism climate potential for central Europe - the example of Luxembourg. Theor Appl Climatol 114, 193-202

Matzarakis A (2014): Transfer of climate data for tourism applications - The Climate-Tourism/TransferInformation-Scheme. Sustain Environ Res 24, 273-280

Mayer H, Höppe P (1987): Thermal comfort of man in different urban environments. Theor Appl Climatol 38, 43-49

Mayer H (1993): Urban bioclimatology. Experientia 49, 957-963

Mayer H (2008): KLIMES - a joint research project on human thermal comfort in cities. Ber Meteor Inst AlbertLudwigs-Univ Freiburg 17, 101-117

Mayer H, Holst J, Dostal P, Imbery F, Schindler D (2008): Human thermal comfort in summer within an urban street canyon in Central Europe. Meteorol Z 17, 241-250

Meze-Hausken E (2008): On the (im-)possibilities of defining human climate thresholds. Climatic Change 89, 299-324 
Michalkó G (2001): Turizmus és területfejlesztés. In: Beluszky P, Kovács Z, Olessák D (szerk): A terület- és településfejlesztés kézikönyve. CEBA Kiadó, Budapest, 113-120

Michalkó G (2008): A turisztikai tér társadalomföldrajzi értelmezésének új dimenziói. MTA Doktori értekezés. Magyar Tudományos Akadémia, Földrajztudományi Kutatóintézet, Budapest.

http://real-d.mtak.hu/95/1/Michalko.pdf

Mieczkowski ZT (1985): The tourism climatic index: a method of evaluating world climates for tourism. Can Geogr 29, 220-233

Moreno A, Amelung B (2009): Climate change and tourist comfort on Europe's beaches in summer: A reassessment. Coast Manage 37, 550-568

Moreno A (2010a): Mediterranean tourism and climate (change): a survey based study. Tour Hosp Plan Dev 7 , $253-265$

Moreno A (2010b): Climate change and tourism. Impacts and vulnerability in Coastal Europe. Doctoral Dissertation, Maastricht University, Maastricht.

http://digitalarchive.maastrichtuniversity.nl/fedora/get/guid:c0d5d520-b8f8-4756-80b3bc7e981f2e06/ASSET1

Morgan R, Gatell E, Junyent R, Micallef A, Özhan E, Williams AT (2000): An improved user-based beach climate index. $J$ Coast Conserv 6, 41-50

Moss RH, Edmonds JA, Hibbard KA, Manning MR, Rose SK, van Vuuren DP, Carter TR, Emori S, Kainuma M, Kram T, Meehl GA, Mitchell JFB, Nakicenovic N, Riahi K, Smith SJ, Stouffer RJ, Thomson AM, Weyant JP, Wilbanks TJ (2010): The next generation of scenarios for climate change research and assessment. Nature $463,747-756$

MTÜ (2016): Turizmus Magyarországon 2015. Magyar Turisztikai Ügynökség, Budapest. http://itthon.hu/documents/28123/4083489/MTE_4000_105x210_LA4_StatVegleges_2015_HU_web.pdfle55 9688c-549d-4008-bc63-fabfb7e3a604

Nakano J, Tanabe S-I (2004): Thermal comfort and adaptation in semi-outdoor environments. ASHRAE Trans 110, 543-553

Nakicenovic N, Alcamo J, Davis G, de Vries B, Fenhann J, Gaffin S, Gregory K, Grübler A, Jung TY, Kram T, La Rovere EL, Michaelis L, Mori S, Morita T, Pepper W, Pitcher H, Price L, Riahi K, Roehrl A, Rogner H-H, Sankovski A, Schlesinger M, Shukla P, Smith S, Swart R, van Rooijen S, Victor N, Dadi Z (2000): IPCC special report on emissions scenarios. Cambridge University Press, Cambridge.

https://www.ipcc.ch/pdf/special-reports/emissions_scenarios.pdf

Nastos PT, Matzarakis A (2003): Human bioclimatic conditions, trends, and variability in the Athens University Campus, Greece. Adv Meteorol 2013, Article ID: 976510

NATéR (2016): Nemzeti Alkalmazkodási Térinformatikai Rendszer. http://nater.mfgi.hu/

Ndetto EL, Matzarakis A (2013): Basic analysis of climate and urban bioclimate of Dar es Salaam, Tanzania. Theor Appl Climatol 114, 213-226

Németh Á (2013): Estimation of tourism climate in the Lake Balaton Region, Hungary. J Environ Geogr 6, 4955

Németh $\dot{A}$ (2015): Observed changes in the tourism climate potential of the Lake Balaton Region based on the second generation Climate Index for Tourism (CIT). In: Demiroğlu OC, de Freitas CR, Scott D, Kurnaz ML, Ünalan D (szerk): Proceed 4th Int Conf on Climate, Tourism and Recreation - CCTR2015. Istanbul Policy Center, Istanbul, 77-81

Nicholls S, Amelung B (2008): Climate change and tourism in Northwestern Europe: Impacts and adaptation. Tourism Anal 13, 21-31

Nikolopoulou M, Steemers $K$ (2003): Thermal comfort and psychological adaptation as a guide for designing urban spaces. Energ Buildings 35, 95-101

Nikolopoulou M, Lykoudis $S$ (2006): Thermal comfort in outdoor urban spaces: analysis across different European countries. Build Environ 41, 1455-1470

Nikolopoulou M, Lykoudis $S$ (2007): Use of outdoor spaces and microclimate in a Mediterranean urban area. Build Environ 42, 3691-3707

OECD (2007): Climate change in the European Alps. Adapting winter tourism and natural hazards management. OECD Publications

OGIMET (2014): Weather Information Service. http://www.ogimet.com/home.phtml.en 
Oliveira S, Andrade $H$ (2007): An initial assessment of the bioclimatic comfort in an outdoor public space in Lisbon. Int J Biometeorol 52, 69-84

OMSZ (2015a): Éghajlati adatsorok 1901-2010, Szeged. Országos Meteorológiai Szolgálat, Budapest. http://met.hu/eghajlat/magyarorszag_eghajlata/eghajlati_adatsorok/

OMSZ (2015b): Városok éghajlati jellemzői. Országos Meteorológiai Szolgálat, Budapest. http://www.met.hu/eghajlat/magyarorszag_eghajlata/varosok_jellemzoi/Budapest/

Orosz L (2016): Nemzeti Alkalmazkodási Térinformatikai Rendszer (NATéR). Felhasználói kézikönyv. Magyar Földtani és Geofizikai Intézet, Budapest

Pantavou K, Theoharatos G, Santamouris M, Asimakopoulos D (2013): Outdoor thermal sensation of pedestrians in a Mediterranean climate and a comparison with UTCI. Build Environ 66, 82-95

Pálvölgyi T, Czira T, Dobozi E, Rideg A, Schneller K (2010): A kistérségi szintü éghajlat-változási sérülékenységvizsgálat módszere és eredményei. KLÍMA-21 Füzetek 62, 88-102

Pearlmutter D, Jiao D, Garb Y (2014): The relationship between bioclimatic thermal stress and subjective thermal sensation in pedestrian spaces. Int J Biometeorol 58, 2111-2127

Perch-Nielsen SL, Amelung B, Knutti R (2010): Future climate resources for tourism in Europe based on the daily tourism climatic index. Climatic Change 103, 363-381

Perry AH (1993): Climate and weather information for the package holiday-maker. Weather 48, 410-414

Perry AH (1997): Recreation and tourism. In: Thompson RD, Perry A (szerk): Applied Climatology: Principles and Practice. Routledge, London, 240-248

Peszeki (2011): Településgazdaságtan. Szent István Egyetem, Gödöllő

Péczely Gy (1979): Éghajlattan. Tankönyvkiadó, Budapest

Pongrácz R, Bartholy J, Bartha EB (2013): Analysis of projected changes in the occurrence of heat waves in Hungary. Adv Geosci 35, 115-122

Rátz T (2006): Az éghajlati és időjárási tényezők szerepe az utazási magatartás befolyásolásában. Turizmus Bulletin 10, 42-53

Rohles FH, Nevins RG (1968): Short duration adaptation to comfortable temperatures. ASHRAE Trans 74, 121129

Rohles FH, Nevins RG (1973): Thermal comfort: new directions and standards. Aerosp Med 44, 730-738

Roshan G, Rousta I, Ramesh M (2009): Studying the effects of urban sprawl of metropolis on tourism - climate index oscillation: A case study of Tehran City. J Geogr Reg Plann 2, 310-321

Roshan G, Yousefi R, Fitchett JM (2016a): Long-term trends in tourism climate index scores for 40 stations across Iran: the role of climate change and influence on tourism sustainability. Int J Biometeorol 60, 33-52

Roshan G, Yousefi R, Kovács A, Matzarakis A (2016b): A comprehensive analysis of physiologically equivalent temperature changes of Iranian selected stations for the last half century. Theor Appl Climatol. doi: 10.1007/s00704-016-1950-3

Rothfusz LP (1990): The Heat Index "equation" (or, more than you ever wanted to know about Heat Index). NWS Southern Region Technical Attachment, SR/SSD 90-23, Fort Worth, TX

Rutty M, Scott D (2010): Will the Mediterranean become "too hot" for tourism? A reassessment. Tour Hosp Plan Dev 7, 267-281

Rutty M, Scott D (2013): Differential climate preferences of international beach tourists. Climate Res 57, 259269

Rutty M (2014): Weather and climate for coastal tourism. Doctoral Dissertation, University of Waterloo, Waterloo. https://uwspace.uwaterloo.ca/bitstream/handle/10012/8500/Rutty_Michelle.pdf? sequence $=3$

Rutty M, Scott D (2014): Thermal range of coastal tourism resort microclimates. Tourism Geogr 16, 346-363

Rutty M, Scott D (2015): Bioclimatic comfort and the thermal perceptions and preferences of beach tourists. Int $J$ Biometeorol 59, 37-45

Rutty M, Scott D (2016): Comparison of climate preferences for domestic and international beach holidays: a case study of Canadian travelers. Atmosphere 7, 30

Saaroni H, Pearlmutter D, Hatuka T (2015): Human-biometeorological conditions and thermal perception in a Mediterranean coastal park. Int J Biometeorol 59, 1347-1362

Sábitz J, Szépszó G, Zsebeházi G, Szabó P, Illy T, Bartholy J, Pieczka I, Pongrácz R (2015): A klímamodellekből levezethető indikátorok alkalmazási lehetőségei. Tanulmány, „Nemzeti Alkalmazkodási Térinformatikai Rendszer kialakítása (NATéR)" projekt, Országos Meteorológiai Szolgálat, Eötvös Loránd Tudományegyetem Meteorológiai Tanszék, Budapest. http://www.met.hu/RCMTeR/hu/publikacio/ 
Scharlau K (1943): Die Schwüle als meßbare Größe. Bioklimat Beibl 10, 19-23

Scott D, McBoyle G (2001): Using a 'tourism climate index' to examine the implications of climate change for climate as a tourism resource. In: Matzarakis A, de Freitas CR (szerk): Proceed First Int Workshop on Climate, Tourism and Recreation. International Society of Biometeorology, Commission on Climate, Tourism and Recreation, Halkidiki, 69-88

Scott D, McBoyle G, Schwartzentruber M (2004): Climate change and the distribution of climatic resources for tourism in North America. Climate Res 27, 105-117

Scott D, Gössling S, de Freitas CR (2008): Preferred climates for tourism: case studies from Canada, New Zealand and Sweden. Climate Res 38, 61-73

Scott D, Lemieux C (2010): Weather and climate information for tourism. Proc Environ Sci 1, 146-183

Scott D, Hall CM, Gössling S (2012): Tourism and climate change: impacts, adaptation and mitigation. Routledge, Abingdon

Shiue I, Matzarakis A (2011): Estimation of the tourism climate in the Hunter Region, Australia, in the early twenty-first century. Int J Biometeorol 55, 565-574

Smith K (1993): The influence of weather and climate on recreation and tourism. Weather 48, 398-404

Spagnolo J, de Dear R (2003): A field study of thermal comfort in outdoor and semi-outdoor environments in subtropical Sydney Australia. Build Environ 38, 721-738

Steadman RG (1971): Indices of windchill of clothed persons. J Appl Meteorol 10, 674-683

Steadman $R G$ (1979): The assessment of sultriness. Part I: A temperature-humidity index based on human physiology and clothing science. J Appl Meteorol 18, 861-873

Steadman RG (1984): A universal scale of apparent temperature. J Clim Appl Meteorol 23, 1674-1687

Szalai S, Auer I, Hiebl J, Milkovich J, Radim T, Stepanek P, Zahradnicek P, Bihari Z, Lakatos M, Szentimrey T, Limanowka D, Kilar P, Cheval S, Deak Gy, Mihic D, Antolovic I, Mihajlovic V, Nejedlik P, Stastny P, Mikulova K, Nabyvanets I, Skyryk O, Krakovskaya S, Vogt J, Antofie T, Spinoni J (2013): Climate of the Greater Carpathian Region. Final Technical Report. http://www.carpatclim-eu.org/

Szentimrey T, Bihari Z (2007): Manual of interpolation software MISHv1.02. Országos Meteorológiai Szolgálat, Budapest

Szentimrey T (2011): Manual of homogenization software MASHv3.03. Országos Meteorológiai Szolgálat, Budapest

Szépszó G (2014): A REMO regionális éghajlati modellen alapuló klímadinamikai vizsgálatok a Kárpát-medence éghajlatának jellemzésére. Doktori értekezés. Földtudományi Doktori Iskola, Eötvös Loránd Tudományegyetem, Budapest. http://teo.elte.hu/minosites/ertekezes2014/szepszo_g.pdf

Szépszó G, Illy T, Szabó P (2016): A regionális klímamodellek eredményeinek utófeldolgozása és a NATéR számára szükséges paraméterek eloóllítása. Beszámoló tanulmány, „A sugárzási kényszer változásán alapuló új éghajlati szcenáriók a Kárpát-medence térségére (RCMTéR)" projekt, Országos Meteorológiai Szolgálat, Budapest. http://www.met.hu/RCMTeR/hu/publikacio/

Takács Á, Kovács A, Kiss M, Gulyás Á, Kántor N (2016): Study on the transmissivity characteristics of urban trees in Szeged, Hungary. Hung Geogr Bull 65, 155-167

Tetens VO (1930): Uber einige meteorologische Begriffe. Z Geophys 6, 297-309

Thorsson S, Lindqvist M, Lindqvist $S$ (2004): Thermal bioclimatic conditions and patterns of behaviour in an urban park in Göteborg, Sweden. Int J Biometeorol 48, 149-156

Toy S, Kántor $N$ (2016): Evaluation of human thermal comfort ranges in urban climate of winter cities on the example of Erzurum city. Environ Sci Pollut R. doi: 10.1007/s11356-016-7902-8

Tsitoura M, Tsoutsos T, Daras T (2014): Evaluation of comfort conditions in urban open spaces. Application in the island of Crete. Energy Convers Manage 86, 250-258

Tung C-H, Chen C-P, Tsai K-T, Kántor N, Hwang R-L, Matzarakis A, Lin T-P (2014): Outdoor thermal comfort characteristics in the hot and humid region from a gender perspective. Int J Biometeorol 58, 1927-1939

UCRG (2015): Urban Climate Research Group. Városklíma-kutatócsoport, Éghajlattani és Tájföldrajzi Tanszék, Szegedi Tudományegyetem. http://uhi.geo.u-szeged.hu/ucrg/

Unger J, Lelovics E, Gál T (2014): Local Climate Zone mapping using GIS methods in Szeged. Hung Geogr Bull 63, 29-41

UNWTO (2008): Climate change and tourism - Responding to global challenges. World Tourism Organization and United Nations Environment Programme, Madrid.

http://sdt.unwto.org/sites/all/files/docpdf/climate2008.pdf 
UNWTO (2010): International recommendations for tourism statistics 2008. United Nations Publications, New York. http://unstats.un.org/unsd/publication/SeriesM/seriesm_83revle.pdf

UNWTO (2016a): UNWTO Annual Report 2015. World Tourism Organization, Madrid. http://cf.cdn.unwto.org/sites/all/files/pdf/annual_report_2015_lr.pdf

UNWTO (2016b): Recommendations on accessible information in tourism. World Tourism Organization, Madrid. http://cf.cdn.unwto.org/sites/all/files/docpdf/accesibilidad2016webennuevoaccesible.pdf

Uzzoli A (2015): Klímamodellek a társadalmi alkalmazkodásban - A sérülékenységvizsgálatok hazai eredményei és tapasztalatai. In: Czirfusz M, Hoyk E, Suvák A (szerk): Klímaváltozás - társadalom - gazdaság. Hosszú távú területi folyamatok és trendek Magyarországon. Publikon Kiadó, Pécs, 109-126

VDI (1994): Environmental meteorology, interactions between atmosphere and surface; calculation of short- and long wave radiation. Part I: Climate. VDI 3789, Part 2. Beuth, Berlin

VDI (1998): Methods for the human-biometeorological assessment of climate and air hygiene for urban and regional planning. Part I: Climate. VDI 3787, Part 2. Beuth, Berlin

Vigotti MA, Muggeo VMR, Cusimano R (2006): The effect of birthplace on heat tolerance and mortality in Milan, Italy, 1980-1989. Int J Biometeorol 50, 335-341

Vitt $R$ (2012): Quantification of climate tourism potential based on urban-rural differences. Bachelor Thesis, Meteorological Institute Albert-Ludwigs-University Freiburg, Freiburg

Vitt R, Gulyás Á, Matzarakis A (2015): Temporal differences of urban-rural human biometeorological factors for planning and tourism in Szeged, Hungary. Adv Meteorol 2015, Article ID: 987576

Volmer RP (1975): A study of the thermal environment in apartments of the elderly. A Master's Thesis. Department of Mechanical Engineering, Kansas State University, Kansas. http://krex.k-state.edu/dspace/handle/2097/11280

Whittlesea E, Amelung B (2010): Cost-a South West: What could tomorrow's weather and climate look like for tourism in the South West of England? National Case Study. South West Tourism, Exeter. http://ukclimateprojections.metoffice.gov.uk/media.jsp? mediaid $=88427 \&$ filetype $=p d f$

WMO (2012): Guide to meteorological instruments and methods of observation. WMO-No. 8., 2008 edition, uptaded in 2010. Part I. Measurement of meteorological variables, Chapter 5. Measurement of surface wind, page Nr.: I.5-13. http://library.wmo.int/pmb_ged/wmo_8_en-2012.pdf

WTTC (2016): Travel \& Tourism Economic Impact 2016 World. World Travel \& Tourism Council, London. http://www.wttc.org/-/media/files/reports/economic\%20impact\%20research/regions\%202016/world2016.pdf

Xi T, Li Q, Mochida A, Meng $Q$ (2012): Study on the outdoor thermal environment and thermal comfort around campus clusters in subtropical urban areas. Build Environ 52, 162-170

Yahia MW, Johansson E (2013): Evaluating the behaviour of different thermal indices by investigating various outdoor urban environments in the hot dry city of Damascus, Syria. Int J Biometeorol 57, 615-630

Yang W, Wong NH, Jusuf SK (2013a): Thermal comfort in outdoor urban spaces in Singapore. Build Environ 59, 426-435

Yang W, Wong NH, Zhang G (2013b): A comparative analysis of human thermal conditions in outdoor urban spaces in the summer season in Singapore and Changsha, China. Int J Biometeorol 57, 895-907

Zaninovic K, Matzarakis A (2009): The bioclimatological leaflet as a means conveying climatological information to tourists and the tourism industry. Int J Biometeorol 53, 369-374

Zaninovic K, Srnec L, Jurkovic RS (2015): How will climate change affect the climate potential of tourism in Croatia? In: Demiroğlu OC, de Freitas CR, Scott D, Kurnaz ML, Ünalan D (szerk): Proceed 4th Int Conf on Climate, Tourism and Recreation - CCTR2015. Istanbul Policy Center, Istanbul, 82-85

Zeng Y, Dong L (2015): Thermal human biometeorological conditions and subjective thermal sensation in pedestrian streets in Chengdu, China. Int J Biometeorol 59, 99-108 


\section{Summary}

In my doctoral dissertation I developed new methodology for the evaluation of tourism climatology and adjusted the evaluation tools to the subjective assessments of the Hungarian residents based on their reactions on the thermal conditions. With the help of the original and the modified methods I evaluated the current state and future possible evolution of the tourism climate potential of Hungary and some highlighted tourism destinations.

Since the dissertation covers the area of tourism climatology about which hardly any Hungarian language studies can be found, I provided a detailed overview of the role climatic conditions play in tourism. Most importantly I aimed at presenting the possible utilization of climatic information from a touristic point of view. I collected the disciplines of tourism climate evaluation and the most important expectations towards evaluation methods. I also explained to what extent the previous elementary and the later bioclimatic indices are suitable for the quantification of climatic circumstances. I provided a detailed description of the most up-todate evaluation methods (Tourism Climatic Index - TCI, Climate Index for Tourism - CIT, Climate-Tourism-Information-Scheme - CTIS) and their general principles (Chapter 2).

The most important results and conclusions are summarized below.

I. I identified problems and deficiencies in connection with the structure and credibility of TCI and CTIS indices based on my experience and the international literature of the discipline (Kovács and Unger 2014a, 2014b, Kovács et al. 2014, 2016, 2017).

1. During the critical examination of the methods I found that the current temporal resolution of the TCI index is insufficient, its thermal components (daytime and daily comfort index) seem to be outdated, moreover the rating score systems of the components and the weighing of the sub-indices are arbitrary. In connection with the CTIS I found that the generally used value ranges and thresholds do not reflect the subjective reactions of local residents (Chapter 3.1).

2. Since the evaluation of the thermal environment is a highly subjective process, I emphasized the importance of the standardization of the evaluation methods (scale, rating score system and thresholds) based on the actual reactions of the local residents or tourists of a given region (Chapter 3.2).

II. I improved the methodology of TCI and adapted the TCI and CTIS to the Hungarian residents' subjective evaluation on thermal conditions (Kovács and Unger 2014a, 2014b, Kovács et al. 2014, 2016, 2017, Kántor et al. 2016a).

3. I modified the structure of the TCI.

a. I updated the thermal components of the TCI: I worked out a new methodology which makes it possible to integrate the Physiological Equivalent Temperature (PET) index into the place of the original thermal components of the TCI (Chapter 3.1 and 4.1.2).

b. I modified the temporal resolution of the TCI: I proposed a ten-day system and in connection with this I modified the rating score system of the precipitation sub-index (Chapter 3.1 and 4.2.1). 
4. I specified the seasonal patterns of the subjective responses given by Hungarian residents on the thermal environment. I determined that people are more tolerant towards warmer thermal conditions in any seasons than towards colder ones. The seasonal trend of the neutral temperature given in PET (spring $\sim$ autumn $<$ summer) shows Hungarian residents' mid-year climatic adaptation processes. I discovered significant differences compared to the original PET value ranges, among which stands out Hungarian residents' higher tolerance towards warmer thermal conditions in the transition seasons (Chapter 4.1 and 5.2).

5. I adjusted the thermal components of the TCI to Hungarian residents: I developed a new rating score system based on the actual, seasonally changing subjective responses of the Hungarian population (Chapter 3.1, 4.1.2 and 5.3).

6. I adjusted the thermal components of the CTIS to the local population: I designated seasonal PET value ranges according to their thermal sensation patterns and after this I integrated the zones perceived as neutral, warm or cold by the Hungarian residents (PET-thresholds) into the CTIS as new thermal components (Chapter 3.1, 4.1.2 and 5.3).

\section{I evaluated the climate potential of a few highlighted local and European tourist destinations based on the TCI, modified TCI (mTCI) and CTIS (Kovács and Unger} 2014a, 2014b, Kovács et al. 2016).

7. I marked out a considerable difference between the yearly distribution of the TCI and the mTCI. In case of the TCI, an intensive improvement can be observed during the spring months after the more disadvantageous winter conditions. The most favourable conditions can be detected from May to September in the local areas and from June to August in the northern regions. During the autumn conditions quickly decline. Yearly distribution thus takes on a structure of a "summer peak". Contrary to this, in case of the mTCI, the dispersion is "bimodal" meaning that whereas the most optimal climate is during some of the spring and autumn months (usually in April and September-October), conditions are more disadvantageous during the summer period. In case of the Southern-European regions, I got a mild "bimodal" structure based on the TCI dispersion and a strong one based on the mTCI (Chapter 6.1.1).

8. With the division of the TCI and mTCI into sub-indices I managed to show that principally the daytime comfort index $(C I d / m C I d)$ is responsible for the different yearly course of the two indices and the significant differences between the examined areas. The effects of the other sub-indices (CIa/mCIa, R, S, W) can contribute to this to a smaller extent (Chapter 6.1.1).

9. The evaluations based on either mTCI and CTIS show that the transitional seasons are the most suitable periods for outdoor activities in all the examined territories. The distribution of the mTCI is strongly "bimodal" in all areas. As a result of the CTIS-based complex evaluation I can confirm that May and September seem to be the most favourable months in Hungary and the northern regions with relatively pleasant thermal conditions during the summer season as well in the latter territories. The transitional seasons - particularly April and October - can be recommended for outdoor activities in the Southern-European regions as well. I also 
proved that the above picture is nuanced by precipitation because the probability of it is the highest in those periods which are considered to be the most favourable (Chapter 6.1.1 and 6.1.2).

IV. I analyzed the possible future tourism climate potential of Hungary based on the TCI and mTCI (Kovács et al. 2017).

10. Based on the measurements reflecting the current climate I found that the yearly evolution of both TCI and mTCI reflects the tendencies observed during the evaluation made by the given indices on the tourist destinations. That is to say, according to the TCI evaluation, I received the most unfavourable conditions for winter whereas the period between May and September showed favourable conditions. The results here also prove that poor winter conditions show intensive improvement during spring, then the conditions remain stable between May and September just to show a great decline during the autumn period. In case of the mTCI where I left out the winter months - the most unfavourable months are November and March. Spring brings a significant improvement here as well followed by a slight decline between June and September. After this another improvement and then a decline can be observed until the end of autumn (Chapter 6.1.1 and 6.2.1).

11. I found that TCI and mTCI show equivalent tendencies for summer and similar for spring and autumn until the end of the $21^{\text {st }}$ century. According to both indices, an unfavourable change can be expected for the summer months which is particularly excessive in July and August (1-3 categories). According to the TCI, stable or slightly improving (by 1 category) conditions can be anticipated for spring. mTCI shows a significant improvement for March followed by a stable or slightly improving condition in April and - contrary to the TCI - a decline by 1 category for the majority of the country in May. Equal tendencies cannot be observed during the autumn months either. Based on the TCI, unchanged conditions can be anticipated for September, significantly improving ones for October and unchanged or at some areas improving by 1 category for November. mTCI shows a decline by 1 category for September such as for May, an improvement for October (similarly to TCI), and an improvement by 1 category for November almost everywhere (Chapter 6.2.2). 
Függelék 


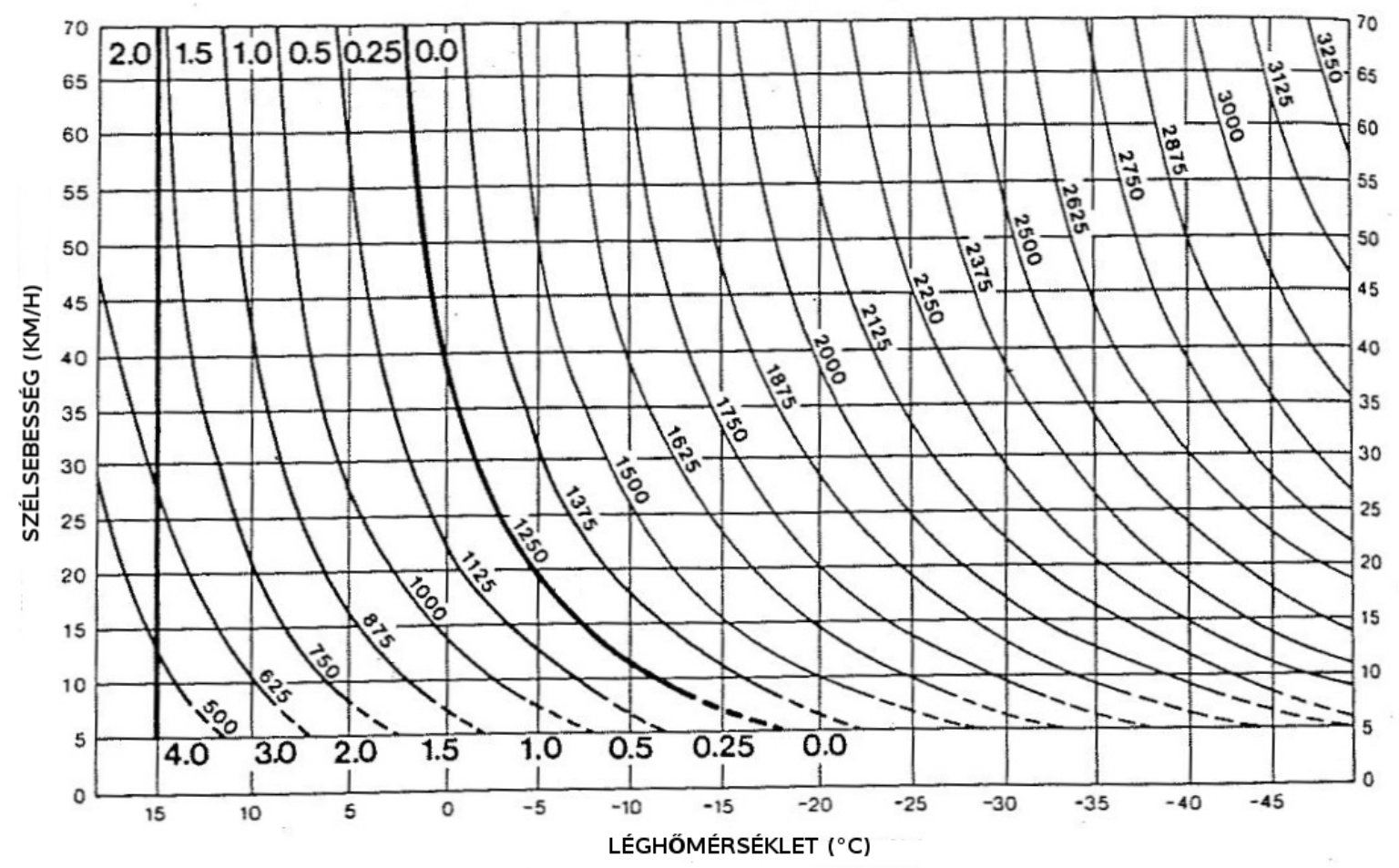

1. ábra: A „szélcsípősség” (,wind chill”) hütőhatása (W/m²/h) a Turisztikai klíma index (TCI) szélsebesség alindexéhez tartozó értékelő pontokkal (Mieczkowski 1985) 

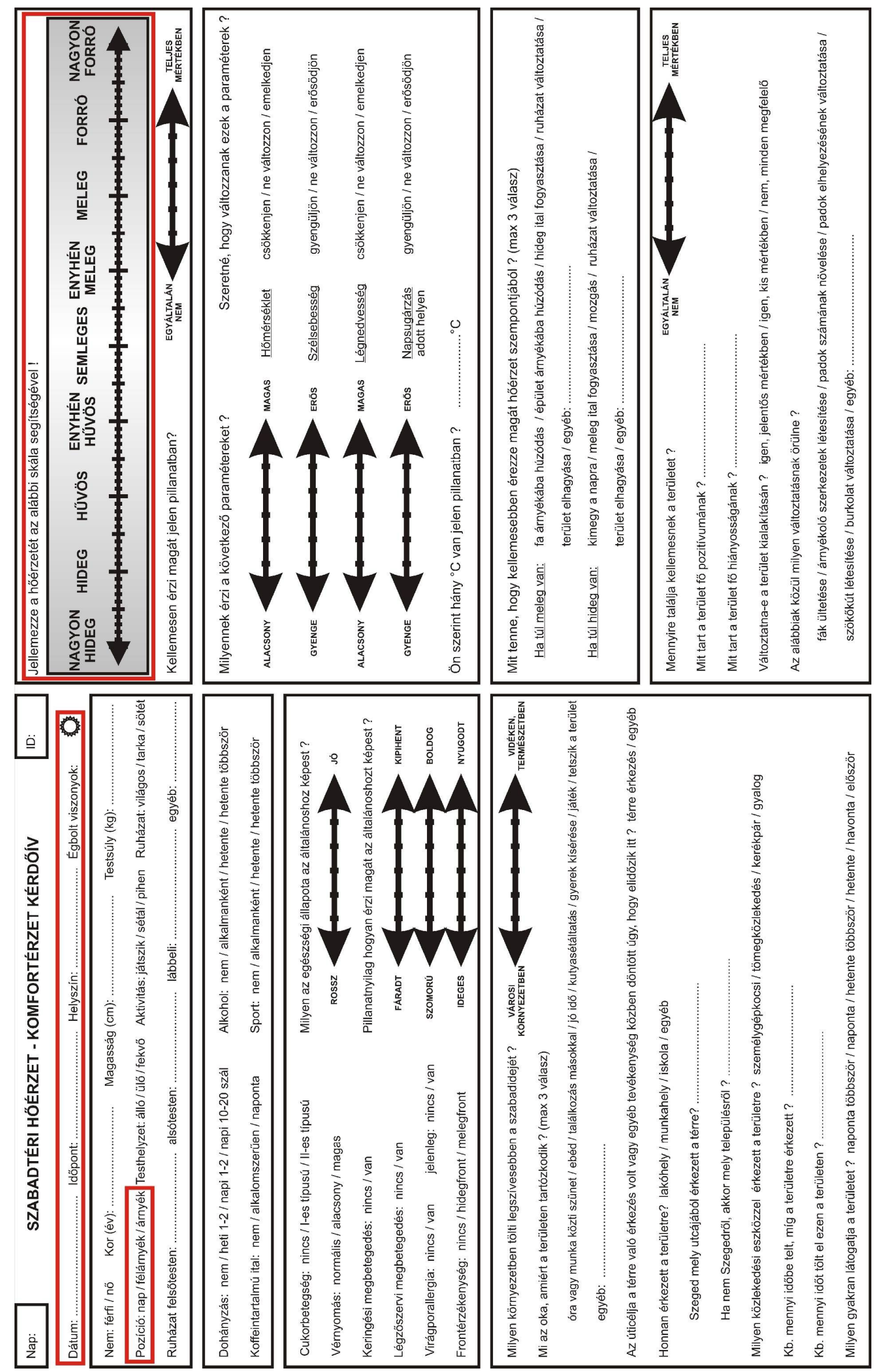

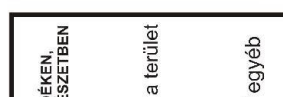
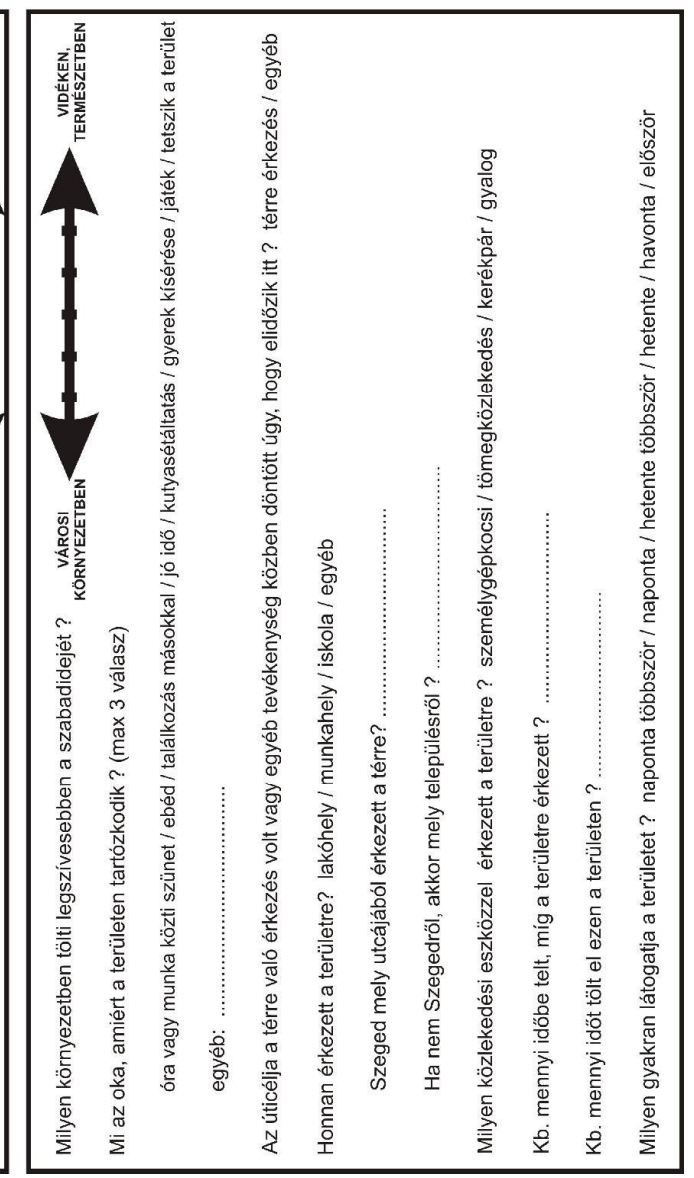

2. ábra: A humánkomfort-felmérés kérdőíve (összeállította Kántor N.), kiemelve az elemzéshez felhasznált részeket 
1. táblázat: Regressziós technikát alkalmazó szabadtéri humánkomfort-tanulmányok (Kántor et al. 2016a)

\begin{tabular}{|c|c|c|c|c|c|c|c|c|c|c|c|c|}
\hline 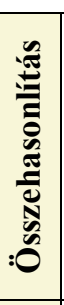 & 1 & 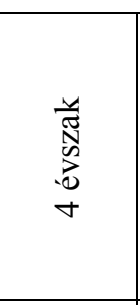 & I & 1 & 1 & 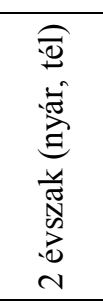 & 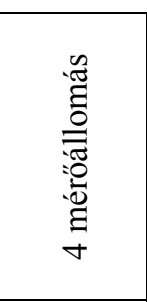 & 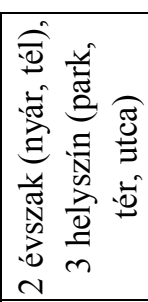 & 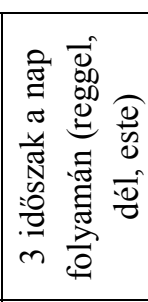 & 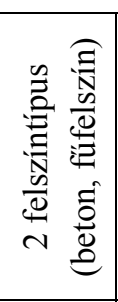 & 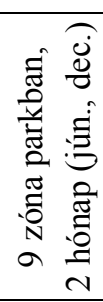 & 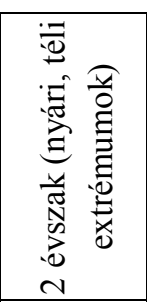 \\
\hline 氖 & 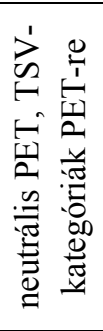 & 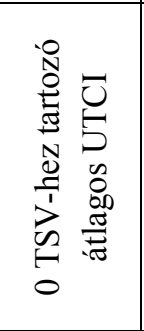 & 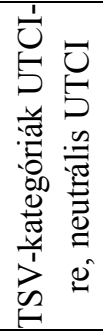 & 1 & 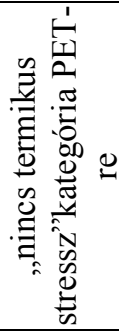 & 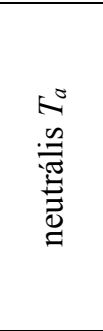 & I & 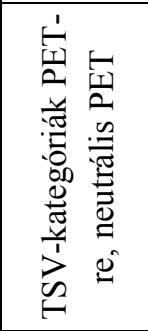 & 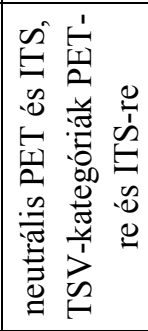 & 1 & 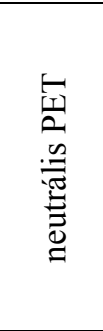 & 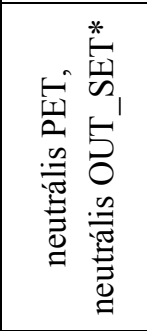 \\
\hline 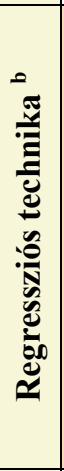 & 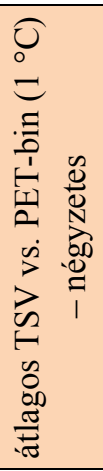 & 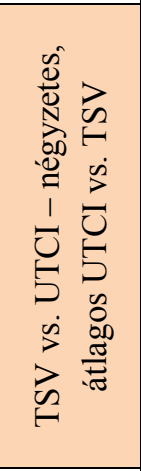 & 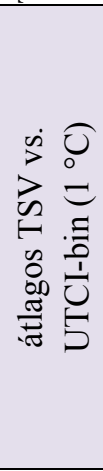 & 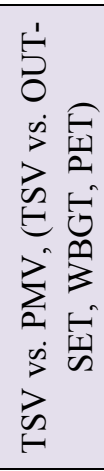 & 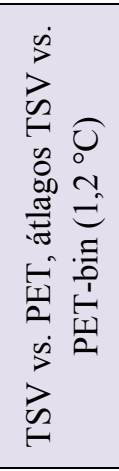 & 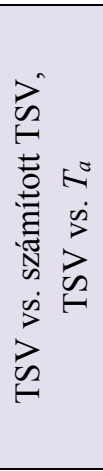 & 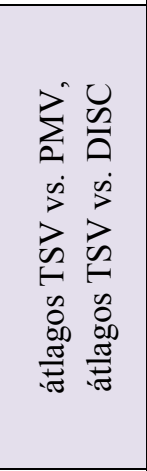 & 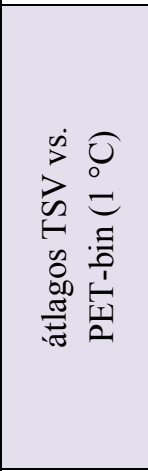 & 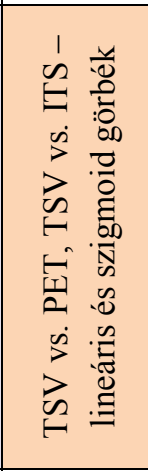 & $\begin{array}{l}n \\
\triangleq \\
\dot{D} \\
D \\
\dot{2} \\
\qquad\end{array}$ & 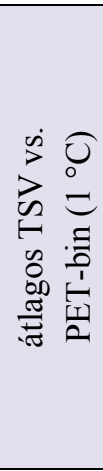 & 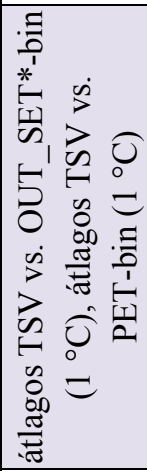 \\
\hline 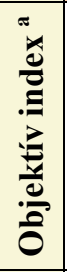 & $\stackrel{5}{2}$ & $\begin{array}{l}\vec{U} \\
\text { S }\end{array}$ & $\begin{array}{l}\vec{U} \\
. \\
\end{array}$ & 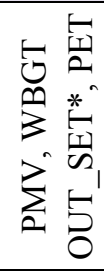 & $\stackrel{\underline{\underline{y}}}{\underline{2}}$ & 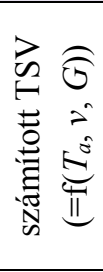 & $\begin{array}{l}U \\
\overline{0} \\
\sum_{0}\end{array}$ & $\frac{5}{2}$ & $\begin{array}{l}n \\
\Xi \\
\stackrel{5}{\omega}\end{array}$ & $\tilde{\Theta}$ & $\frac{15}{2}$ & 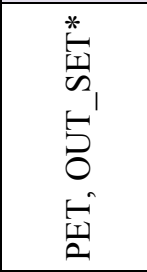 \\
\hline$\vec{\omega}$ & 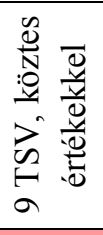 & $\begin{array}{l}\overrightarrow{2} \\
\qquad \\
r\end{array}$ & $\begin{array}{l}\vec{n} \\
\qquad \\
n\end{array}$ & $\begin{array}{l}\overrightarrow{i n} \\
i n\end{array}$ & $\stackrel{\Delta}{n}$ & $\underset{n}{i}$ & 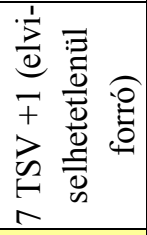 & $\begin{array}{l}\vec{b} \\
\qquad \\
a\end{array}$ & $\underset{n}{\Delta}$ & $\begin{array}{l}\vec{b} \\
\qquad \\
n\end{array}$ & in & $\begin{array}{l}B \\
i \\
a\end{array}$ \\
\hline 趂 & $\begin{array}{l}\vec{D} \\
\mathbb{D} \\
\stackrel{N}{N} \\
\omega\end{array}$ & 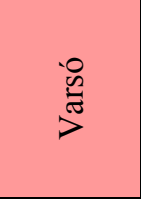 & 离 & 莺 & $\begin{array}{l}3 \\
0 \\
80 \\
0 \\
0 \\
0\end{array}$ & : & 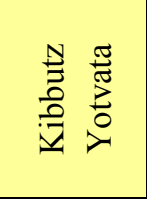 & 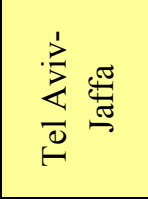 & 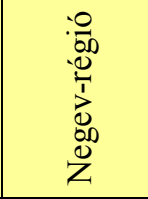 & 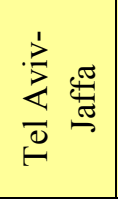 & 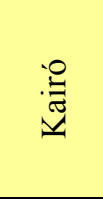 & 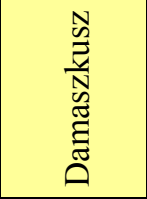 \\
\hline 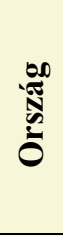 & 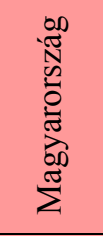 & 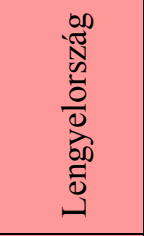 & 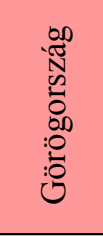 & 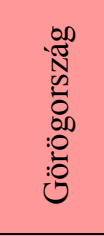 & 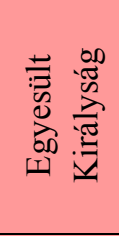 & 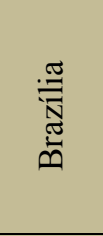 & $\begin{array}{l}\overline{\mathscr{J}} \\
\mathbb{N}\end{array}$ & $\begin{array}{l}\overline{\mathscr{J}} \\
\mathbb{N}\end{array}$ & $\begin{array}{l}\overline{\mathscr{J}} \\
\mathbb{\Xi}\end{array}$ & $\begin{array}{l}\overline{\mathbb{J}} \\
\mathbb{\Xi}\end{array}$ & 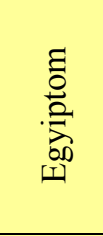 & 莺 \\
\hline 萬 & 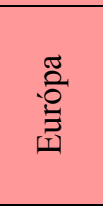 & 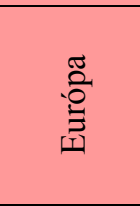 & 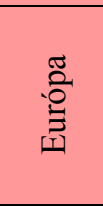 & 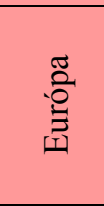 & 总 & $\begin{array}{l}\frac{\pi}{5} \\
\frac{\pi}{0} \\
\frac{E}{1} \\
\frac{1}{0} \\
0\end{array}$ & 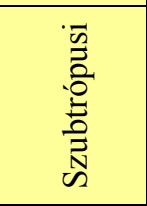 & 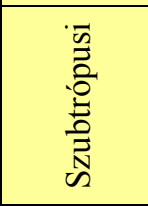 & 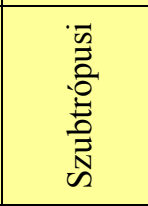 & 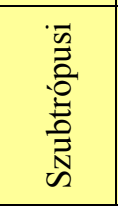 & 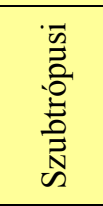 & 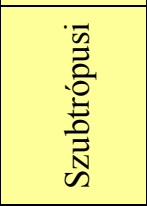 \\
\hline 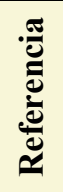 & 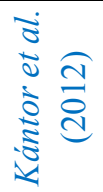 & 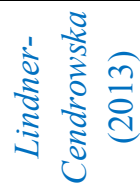 & 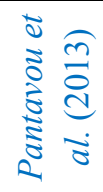 & 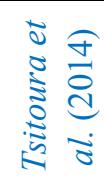 & 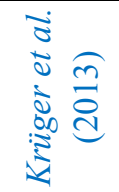 & 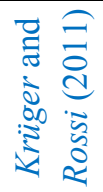 & 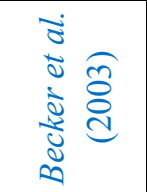 & 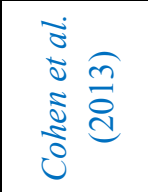 & 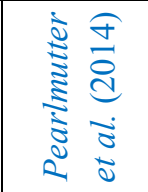 & 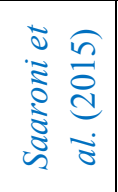 & 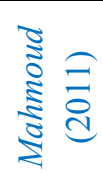 & 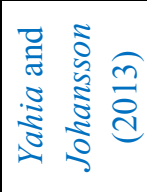 \\
\hline
\end{tabular}




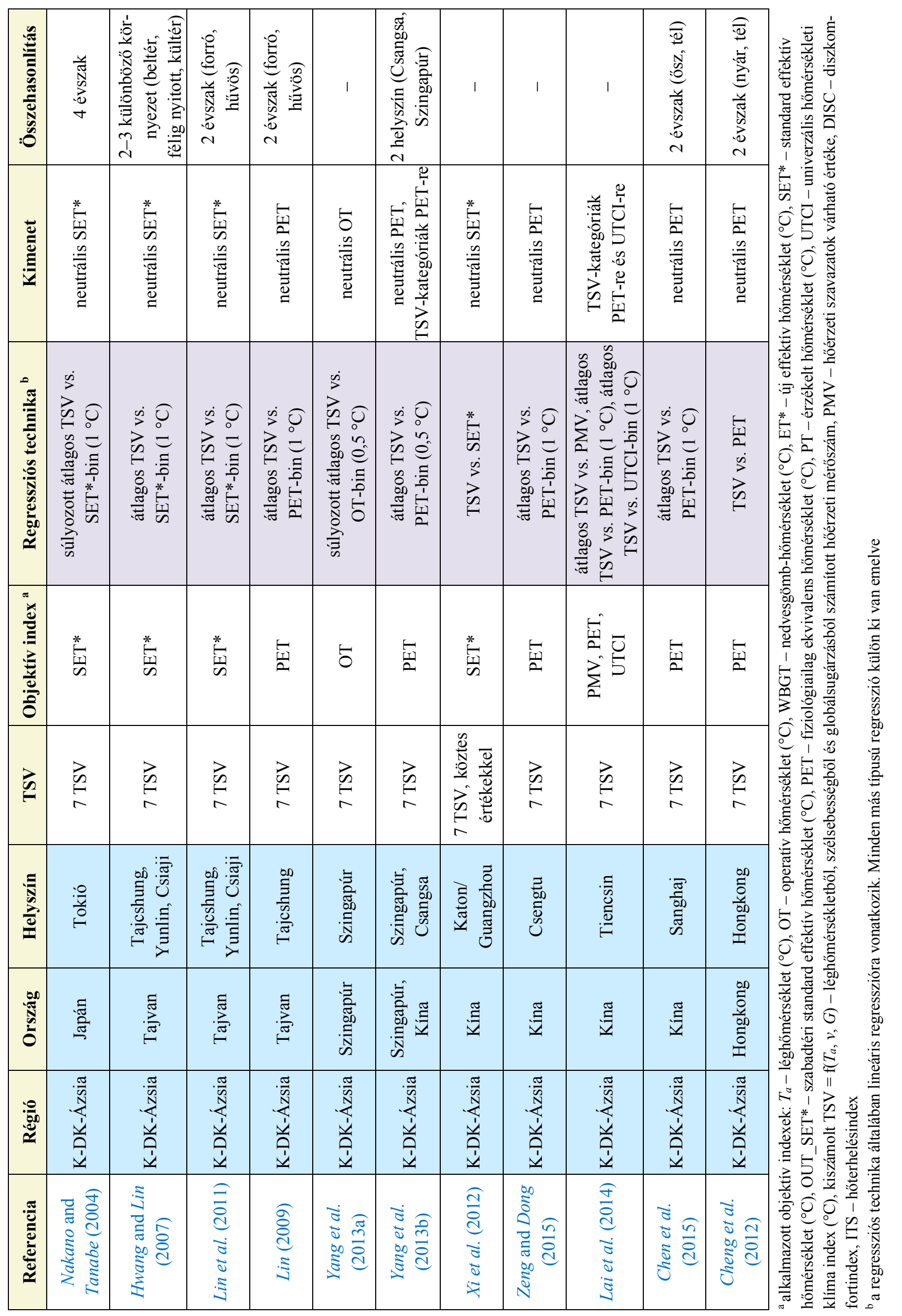



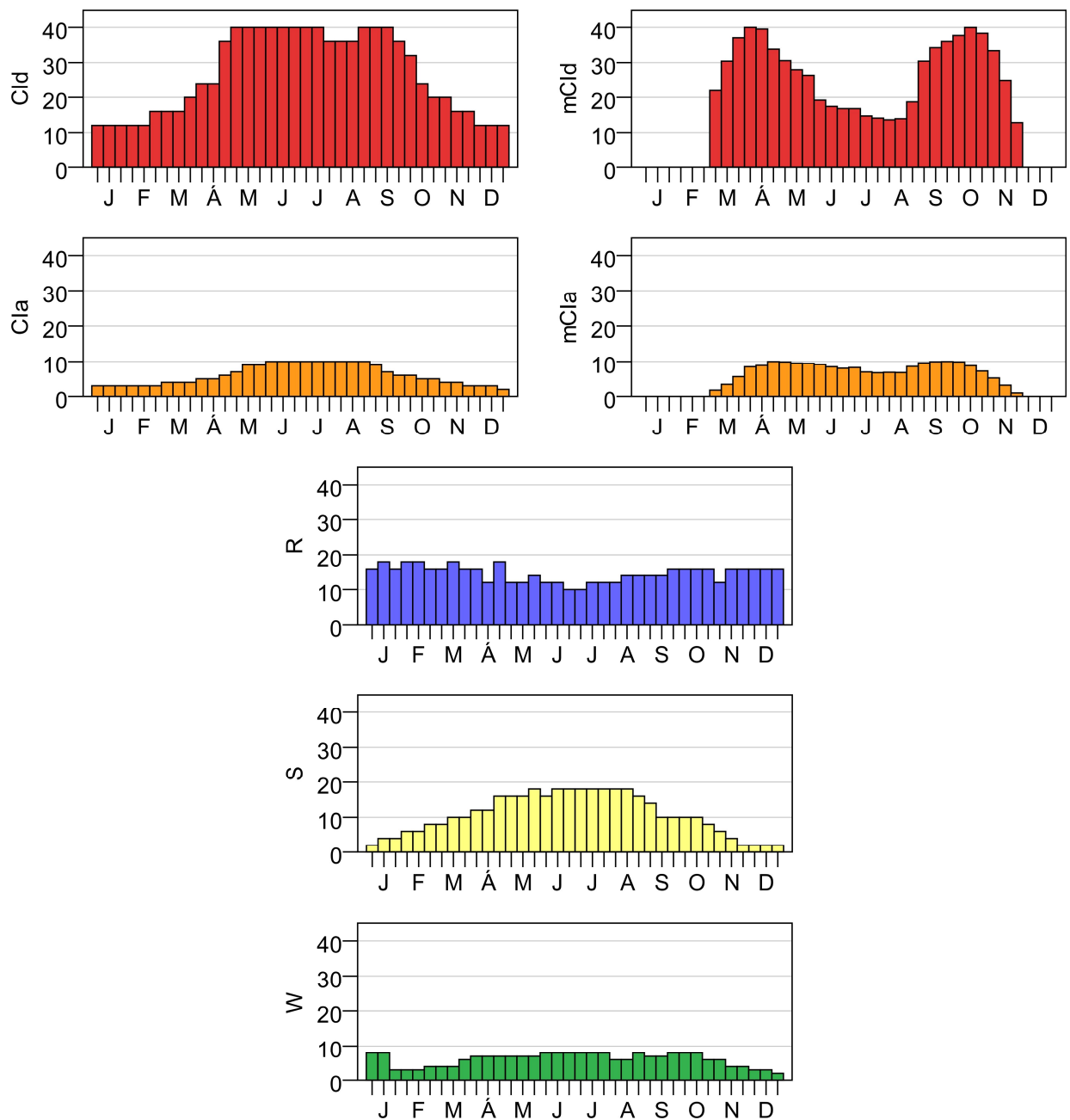

B

Budapest

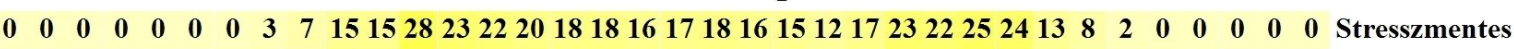
$41119323136322827171916171916151218333638372823127 \quad 1 \quad$ Neutrális

$\begin{array}{llllllllllllllllllllllllllllllllllllllllllllllll}0 & 0 & 0 & 0 & 0 & 0 & 0 & 0 & 0 & 0 & 0 & 0 & 1 & 2 & 5 & 11 & 12 & 14 & 13 & 22 & 21 & 19 & 20 & 9 & 2 & 0 & 0 & 0 & 0 & 0 & 0 & 0 & 0 & 0 & 0 & 0 & \text { Hőstressz }\end{array}$

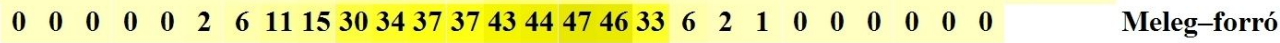

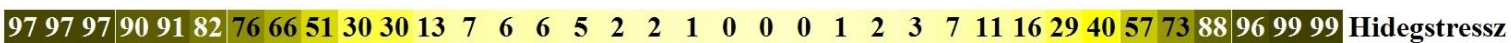
$\begin{array}{lllllllllllllllllllllllllll}77685332 & 31 & 14 & 8 & 6 & 7 & 16 & 9 & 10 & 9 & 5 & 4 & 4 & 6 & 10 & 3 & 7 & 11 & 15 & 28 & 39 & 57 & 72 & 88 & \text { Húvös-hideg }\end{array}$

$\begin{array}{llllllllllllllllllllllllllllllllllllllll}0 & 0 & 0 & 0 & 0 & 0 & 0 & 0 & 0 & 0 & 0 & 0 & 0 & 2 & 3 & 11 & 17 & 20 & 17 & 24 & 33 & 27 & 18 & 15 & 4 & 4 & 2 & 1 & 0 & 0 & 0 & 0 & 0 & 0 & 0 & 0 & \text { Fülledtség }\end{array}$ 202425283034313332393345394443454552495249575751453546344436312615212123 Napsütés $\begin{array}{llllllllllllllllllllllllllllllllllll}26 & 26 & 21 & 11 & 8 & 9 & 8 & 5 & 4 & 2 & 6 & 2 & 4 & 4 & 3 & 5 & 3 & 3 & 3 & 3 & 2 & 2 & 3 & 4 & 4 & 5 & 8 & 9 & 8 & 12 & 15 & 18 & 25 & 28 & 24 & 26 \\ \text { Köd }\end{array}$ $778776838178 \mid 778182817181756978747780717973838378857780828579717973777575$ Száraz nap

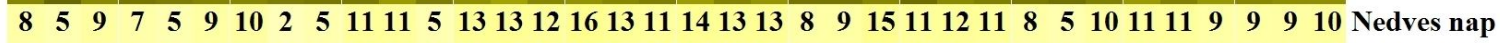
$\begin{array}{llllllllllllllllllllllllllllllllllllllll}1 & 1 & 2 & 2 & 1 & 1 & 2 & 2 & 1 & 2 & 2 & 0 & 0 & 1 & 1 & 1 & 0 & 0 & 1 & 0 & 0 & 0 & 0 & 0 & 1 & 0 & 0 & 0 & 0 & 1 & 0 & 0 & 1 & 1 & 0 & 0 & \text { Szeles } & \text { idő }\end{array}$

$\begin{array}{llllllllllll}\text { I II } & \text { III } & \text { IV } & \text { V } & \text { VI } & \text { VII } & \text { VIII } & \text { IX } & X & \text { XI } & \text { XII }\end{array}$

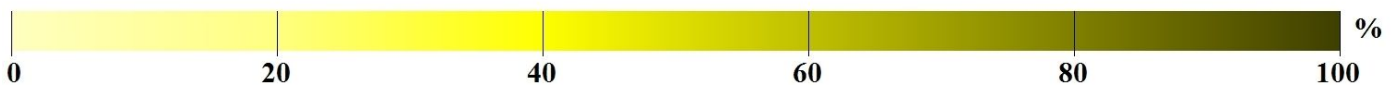

3. ábra: A Turisztikai klíma indexet (TCI) és a módosított Turisztikai klíma indexet (mTCI) felépítő al-indexek évi menete (a), valamint a Klíma-Turizmus-Információs-Rendszer (CTIS) (b) Budapesten, tíznapos felbontásban (1996-2010). Az egyes TCI és mTCI al-indexekkel kapcsolatos tudnivalókat a 6.2. ábra magyarázata tartalmazza. A CTIS-ben a termikus stresszre és a hőérzetre vonatkozó küszöbértékek az 5.3. táblázaton, a többi paramé- 

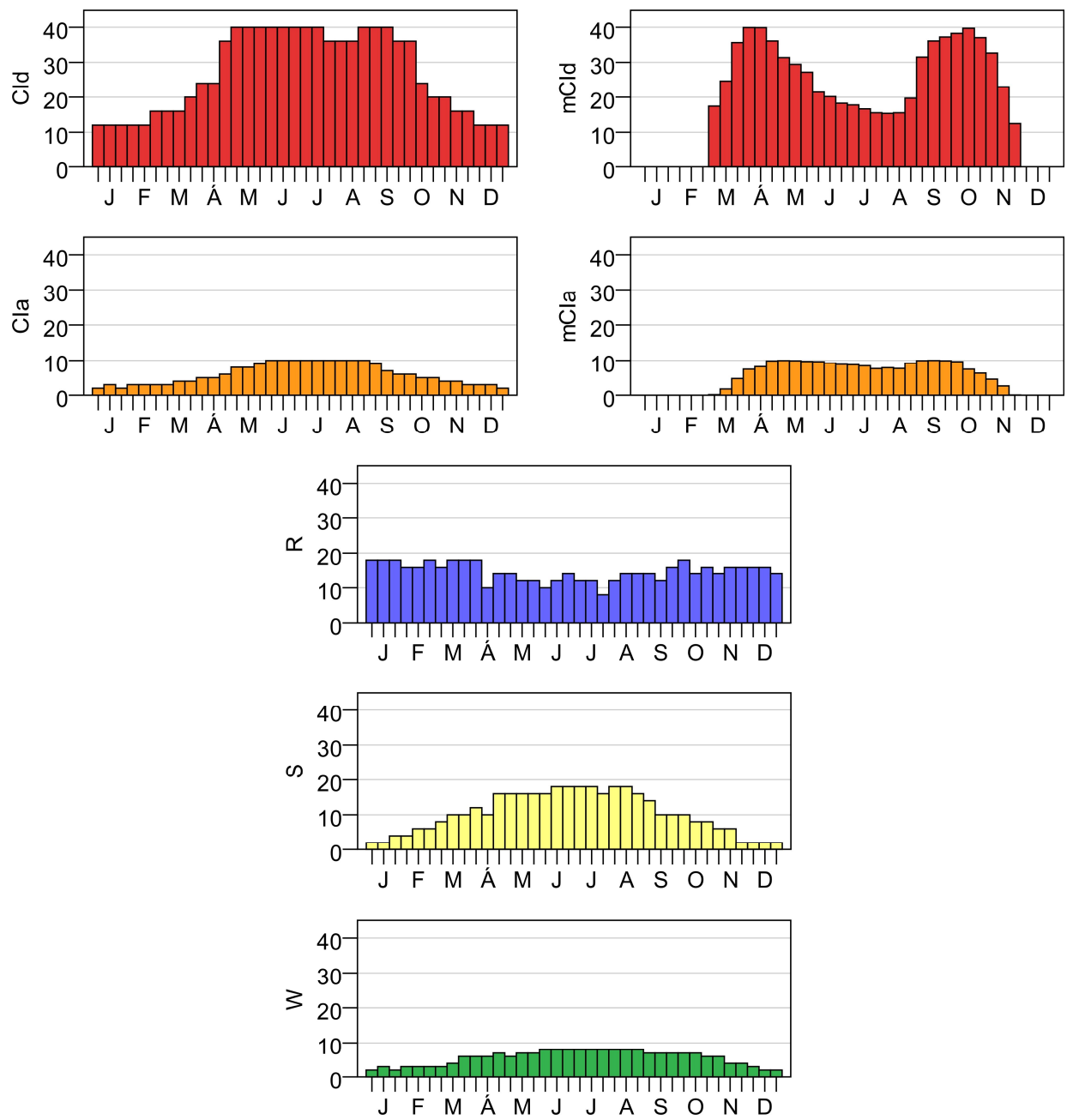

B

Debrecen

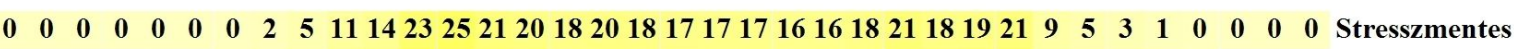
$2716253036342828202019171716161618323335352120127 \quad 1 \quad$ Neutrális

$\begin{array}{llllllllllllllllllllllllllllllllllllllll}0 & 0 & 0 & 0 & 0 & 0 & 0 & 0 & 0 & 0 & 0 & 0 & 1 & 2 & 4 & 9 & 7 & 10 & 10 & 14 & 18 & 14 & 14 & 8 & 1 & 0 & 0 & 0 & 0 & 0 & 0 & 0 & 0 & 0 & 0 & 0 & \text { Hőstressz }\end{array}$

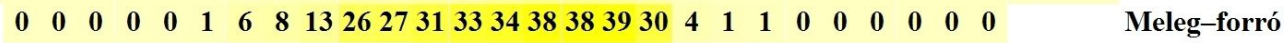

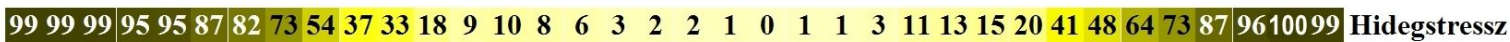
847557393520101181912121111778 8 $13101214204148637388 \quad$ Húvös-hideg

$\begin{array}{llllllllllllllllllllllllllllllllllllllll}0 & 0 & 0 & 0 & 0 & 0 & 0 & 0 & 0 & 0 & 0 & 0 & 3 & 7 & 9 & 18 & 31 & 31 & 32 & 38 & 52 & 47 & 39 & 28 & 10 & 6 & 4 & 3 & 0 & 0 & 0 & 0 & 0 & 0 & 0 & 0 & \text { Fülledtség }\end{array}$ 162323282735293336393044414042454249495045585653483337393934352716211824 Napsütés

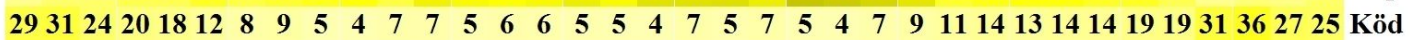
778378817573747984816578757173717276747572738078816976868081768075797975 Száraz nap

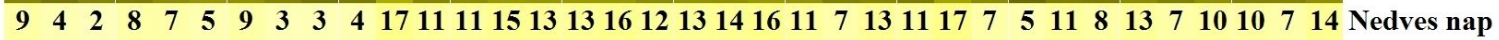
$\begin{array}{lllllllllllllllllllllllllllllllllllllll}1 & 2 & 5 & 2 & 2 & 3 & 5 & 5 & 5 & 3 & 3 & 1 & 3 & 1 & 1 & 1 & 0 & 1 & 2 & 0 & 1 & 0 & 0 & 0 & 1 & 1 & 1 & 1 & 2 & 3 & 1 & 3 & 3 & 2 & 1 & 2 & \text { Szeles idö }\end{array}$

$\begin{array}{lllllllllllll}\text { I II } & \text { III } & \text { IV } & \text { V } & \text { VI } & \text { VII } & \text { VIII } & \text { IX } & \text { X } & \text { XI } & \text { XII }\end{array}$

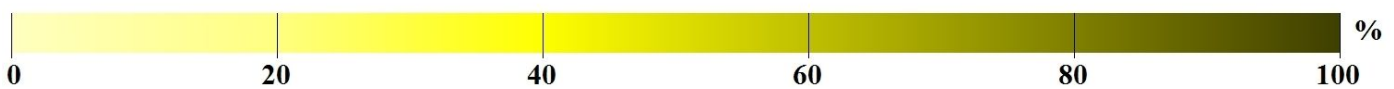

4. ábra: A Turisztikai klíma indexet (TCI) és a módosított Turisztikai klíma indexet (mTCI) felépítő al-indexek évi menete (a), valamint a Klíma-Turizmus-Információs-Rendszer (CTIS) (b) Debrecenben, tíznapos felbontásban (1996-2010). Az egyes TCI és mTCI al-indexekkel kapcsolatos tudnivalókat a 6.2. ábra magyarázata tartalmazza. A CTIS-ben a termikus stresszre és a höérzetre vonatkozó küszöbértékek az 5.3. táblázaton, a többi paraméteré a 2.5. táblázaton alapulnak 
A
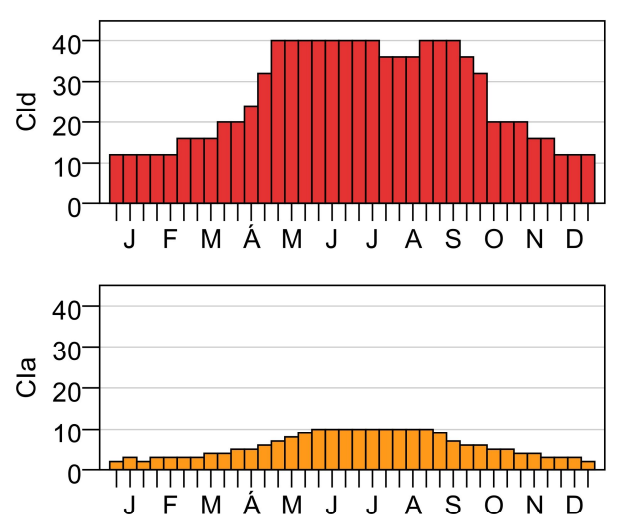

Siófok
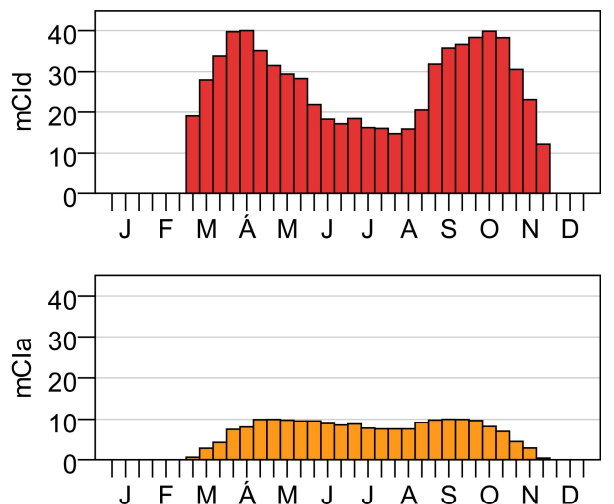
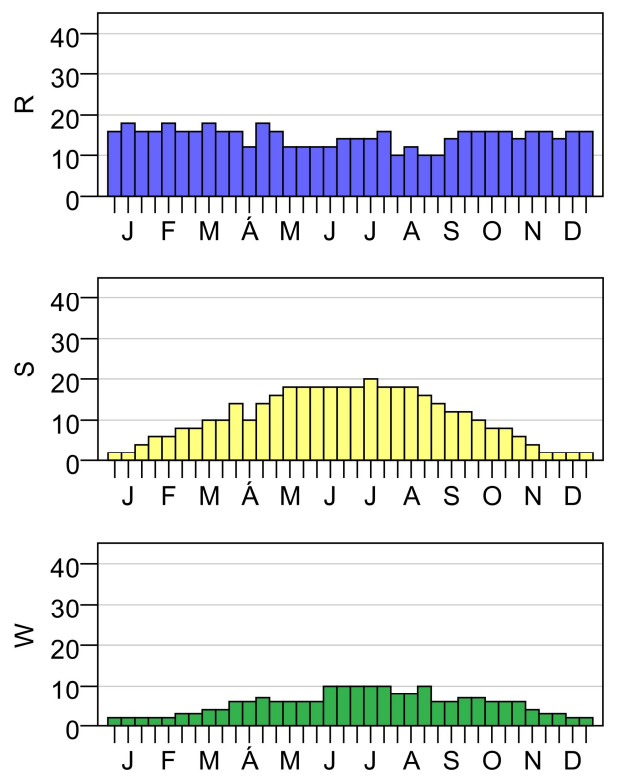

B

Siófok

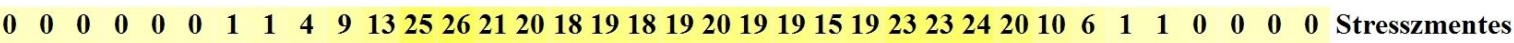
$251025263537312918211920212018162036353738262077600 \quad$ Neutrális

$\begin{array}{llllllllllllllllllllllllllllllllllllll}\mathbf{0} & 0 & 0 & 0 & 0 & 0 & 0 & 0 & 0 & 0 & 0 & 0 & 1 & 1 & 2 & 6 & 10 & 9 & 9 & 15 & 16 & 13 & 12 & 5 & 1 & 0 & 1 & 0 & 0 & 0 & 0 & 0 & 0 & 0 & 0 & 0 & \text { Hóstressz }\end{array}$

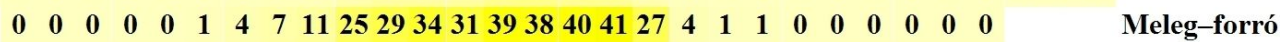

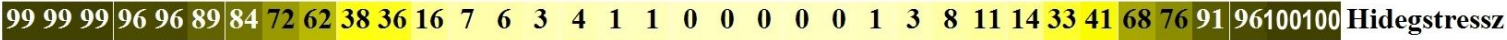

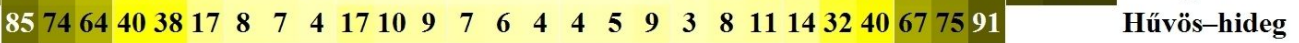

$\begin{array}{llllllllllllllllllllllllllllllllllllll}0 & 0 & 0 & 0 & 0 & 0 & 0 & 0 & 0 & 0 & 0 & 0 & 5 & 10 & 18 & 32 & 39 & 42 & 39 & 52 & 60 & 54 & 54 & 38 & 19 & 14 & 6 & 8 & 0 & 0 & 0 & 0 & 0 & 0 & 0 & 0 & \text { Fülledtség }\end{array}$ 232527353437343736463551485351535457546056616154494449434640323022212022 Napsütés $\begin{array}{llllllllllllllllllllllllllllllllllllllll}33 & 34 & 26 & 17 & 9 & 13 & 10 & 4 & 5 & 3 & 5 & 3 & 2 & 1 & 1 & 2 & 1 & 1 & 1 & 1 & 0 & 1 & 2 & 3 & 4 & 3 & 7 & 9 & 9 & 14 & 18 & 17 & 31 & 36 & 27 & 29 & \text { Köd }\end{array}$ 778579848977778884826782837576777374767978797976777679828483757776757580 Száraz nap

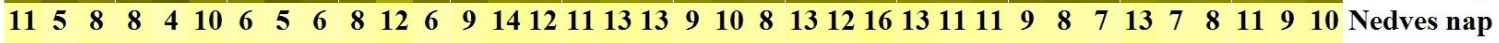

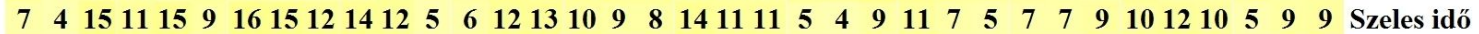

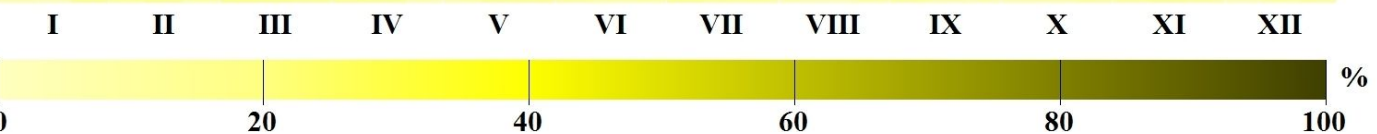

5. ábra: A Turisztikai klíma indexet (TCI) és a módosított Turisztikai klíma indexet (mTCI) felépítő al-indexek évi menete (a), valamint a Klíma-Turizmus-Információs-Rendszer (CTIS) (b) Siófokon, tíznapos felbontásban (1996-2010). Az egyes TCI és mTCI al-indexekkel kapcsolatos tudnivalókat a 6.2. ábra magyarázata tartalmazza. A CTIS-ben a termikus stresszre és a hőérzetre vonatkozó küszöbértékek az 5.3. táblázaton, a többi paraméteré a 2.5. táblázaton alapulnak 
A
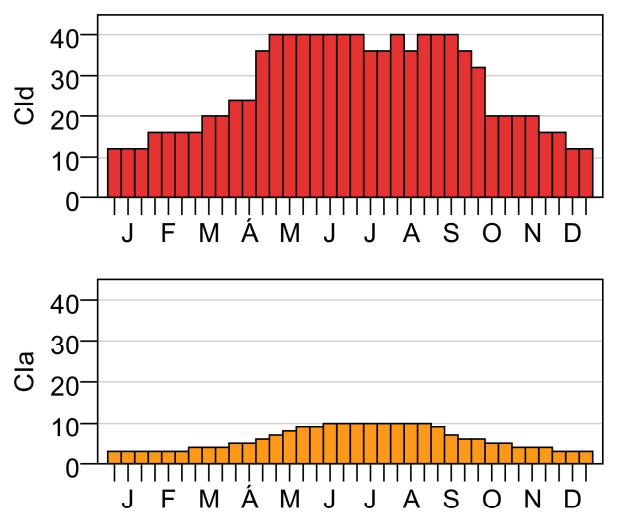

Győr
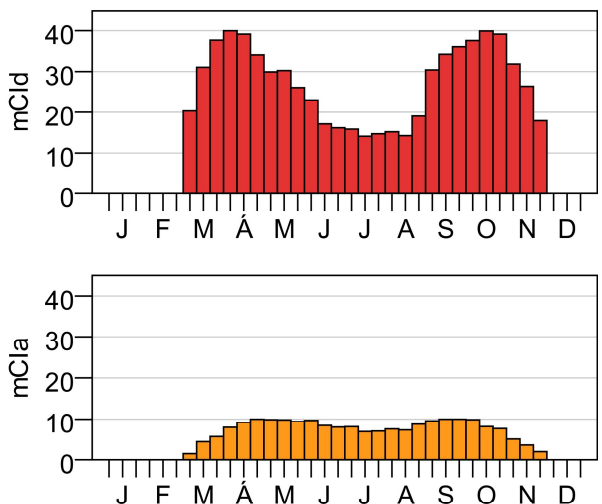
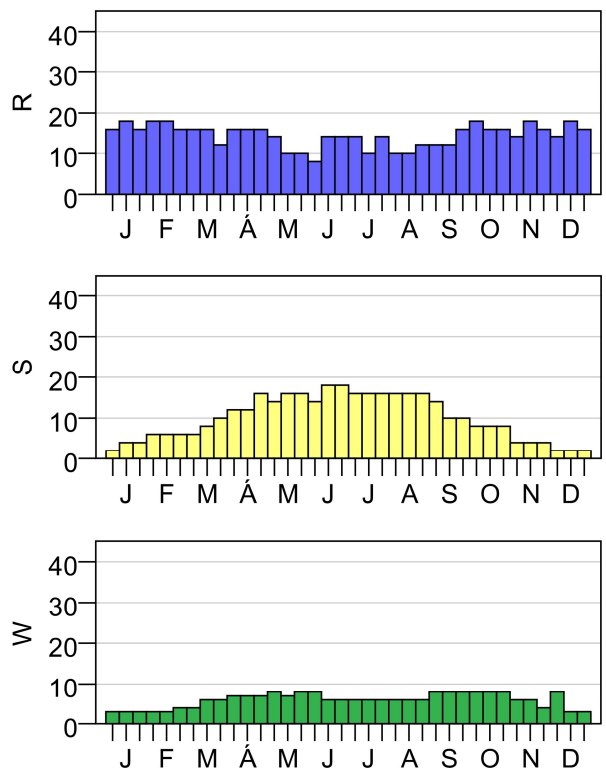

B

Győr

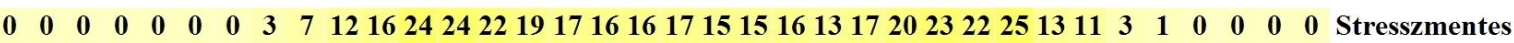
$414202733343230261717161616161614163235343525281292 \quad$ Neutrális

$\begin{array}{lllllllllllllllllllllllllllllllllllllll}0 & 0 & 0 & 0 & 0 & 0 & 0 & 0 & 0 & 0 & 0 & 0 & 2 & 1 & 5 & 7 & 13 & 14 & 14 & 25 & 22 & 17 & 18 & 9 & 2 & 0 & 0 & 0 & 0 & 0 & 0 & 0 & 0 & 0 & 0 & 0 & \text { Hőstressz }\end{array}$

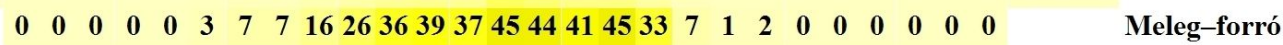

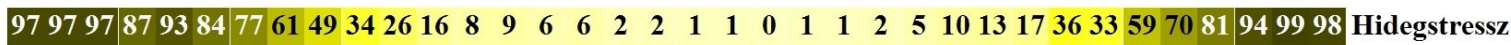

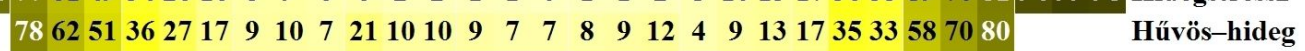

$\begin{array}{llllllllllllllllllllllllllllllllllllllll}0 & 0 & 0 & 0 & 0 & 0 & 0 & 0 & 0 & 0 & 0 & 0 & 0 & 2 & 6 & 14 & 21 & 28 & 18 & 34 & 39 & 32 & 30 & 24 & 7 & 7 & 1 & 1 & 0 & 0 & 0 & 0 & 0 & 0 & 0 & 0 & \text { Fülledtség }\end{array}$ 252927323431293336473958464849445354525552556057504149394642242723232525 Napsütés

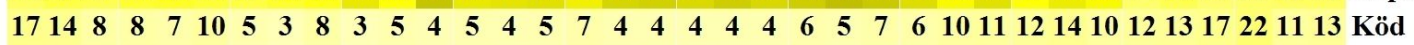
768276838374747770827784777573747783746977718377787382798779718171757978 Száraz nap $\begin{array}{llllllllllllllllllllllllllllllllllllllll}8 & 4 & 8 & 4 & 5 & 8 & 11 & 6 & 12 & 9 & 7 & 6 & 11 & 12 & 16 & 17 & 9 & 9 & 11 & 15 & 12 & 21 & 12 & 13 & 12 & 14 & 9 & 5 & 8 & 9 & 10 & 5 & 11 & 11 & 5 & 6 & \text { Nedves nap }\end{array}$ $\begin{array}{lllllllllllllllllllllllllllllllllllllll}0 & 0 & 1 & 1 & 0 & 1 & 1 & 0 & 1 & 1 & 0 & 0 & 0 & 0 & 0 & 0 & 0 & 0 & 0 & 0 & 0 & 0 & 0 & 0 & 0 & 0 & 0 & 0 & 0 & 1 & 0 & 0 & 0 & 0 & 0 & 0 & \text { Szeles } & \text { idő }\end{array}$

$\begin{array}{lllllllllllll}\text { I } & \text { II } & \text { III } & \text { IV } & \text { V } & \text { VI } & \text { VII } & \text { VIII } & \text { IX } & X & \text { XI } & \text { XII }\end{array}$

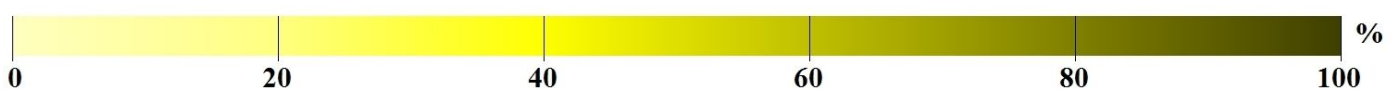

6. ábra: A Turisztikai klíma indexet (TCI) és a módosított Turisztikai klíma indexet (mTCI) felépítő al-indexek évi menete (a), valamint a Klíma-Turizmus-Információs-Rendszer (CTIS) (b) Győrben, tíznapos felbontásban (2000-2010). Az egyes TCI és mTCI al-indexekkel kapcsolatos tudnivalókat a 6.2. ábra magyarázata tartalmazza. A CTIS-ben a termikus stresszre és a hőérzetre vonatkozó küszöbértékek az 5.3. táblázaton, a többi paraméteré a 2.5. táblázaton alapulnak 
A
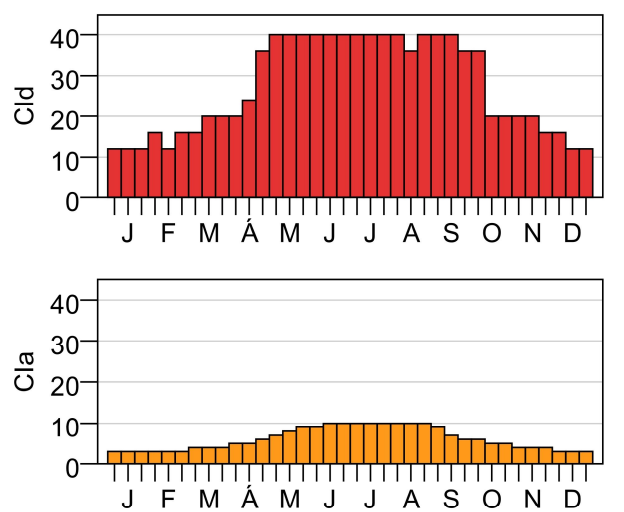

Pécs
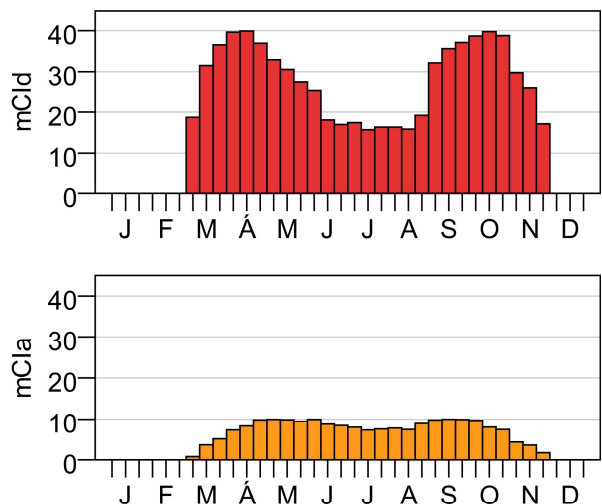
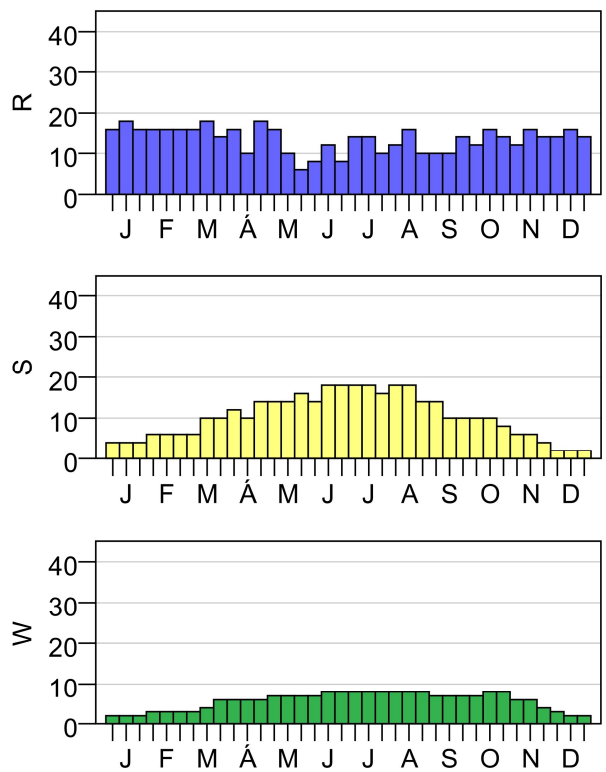

B

Pécs

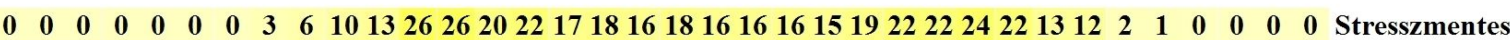
$3121726303839292817181618161617151933333739232691033 \quad$ Neutrális

$\begin{array}{llllllllllllllllllllllllllllllllllllllllll}0 & 0 & 0 & 0 & 0 & 0 & 0 & 0 & 0 & 0 & 0 & 0 & 1 & 1 & 3 & 5 & 11 & 14 & 9 & 20 & 20 & 14 & 18 & 10 & 2 & 0 & 0 & 0 & 0 & 0 & 0 & 0 & 0 & 0 & 0 & 0 & \text { Höstressz }\end{array}$

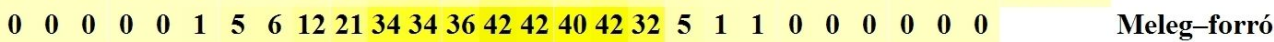

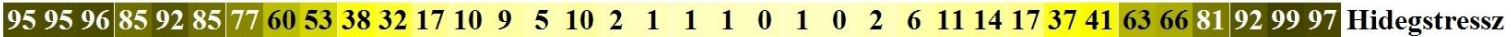

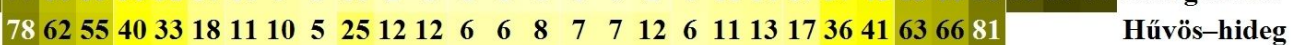

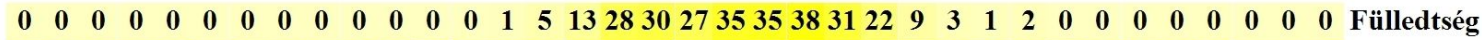
272528312922273431392948384042405155526255576252473841404439293227192117 Napsütés

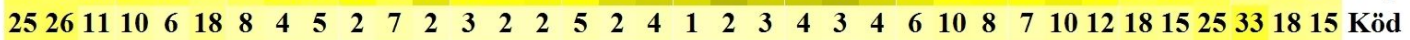
738579858174789075806881797069647672768071767674727180827978728168707373 Száraz nap

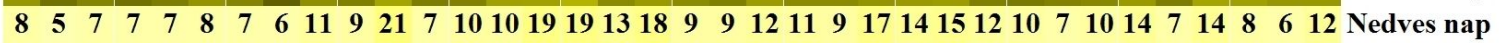
$\begin{array}{llllllllllllllllllllllllllllllllllllll}2 & 3 & 4 & 7 & 4 & 3 & 8 & 7 & 5 & 3 & 2 & 2 & 1 & 3 & 1 & 2 & 2 & 1 & 0 & 1 & 1 & 1 & 0 & 0 & 1 & 0 & 0 & 1 & 3 & 2 & 2 & 2 & 3 & 0 & 1 & 3 & \text { Szeles } & \text { idö }\end{array}$

$\begin{array}{llllllllllll}\text { I II } & \text { III } & \text { IV } & \text { V } & \text { VI } & \text { VII } & \text { VIII } & \text { IX } & \text { X } & \text { XI } & \text { XII }\end{array}$

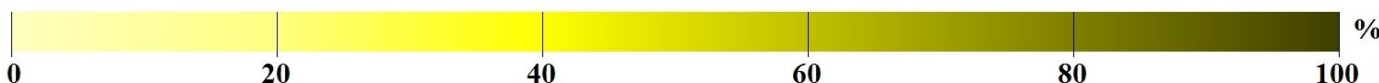

7. ábra: A Turisztikai klíma indexet (TCI) és a módosított Turisztikai klíma indexet (mTCI) felépítő al-indexek évi menete (a), valamint a Klíma-Turizmus-Információs-Rendszer (CTIS) (b) Pécsen, tíznapos felbontásban (2000-2010). Az egyes TCI és mTCI al-indexekkel kapcsolatos tudnivalókat a 6.2. ábra magyarázata tartalmazza. A CTIS-ben a termikus stresszre és a hőérzetre vonatkozó küszöbértékek az 5.3. táblázaton, a többi paraméteré a 2.5. táblázaton alapulnak 
Berlin
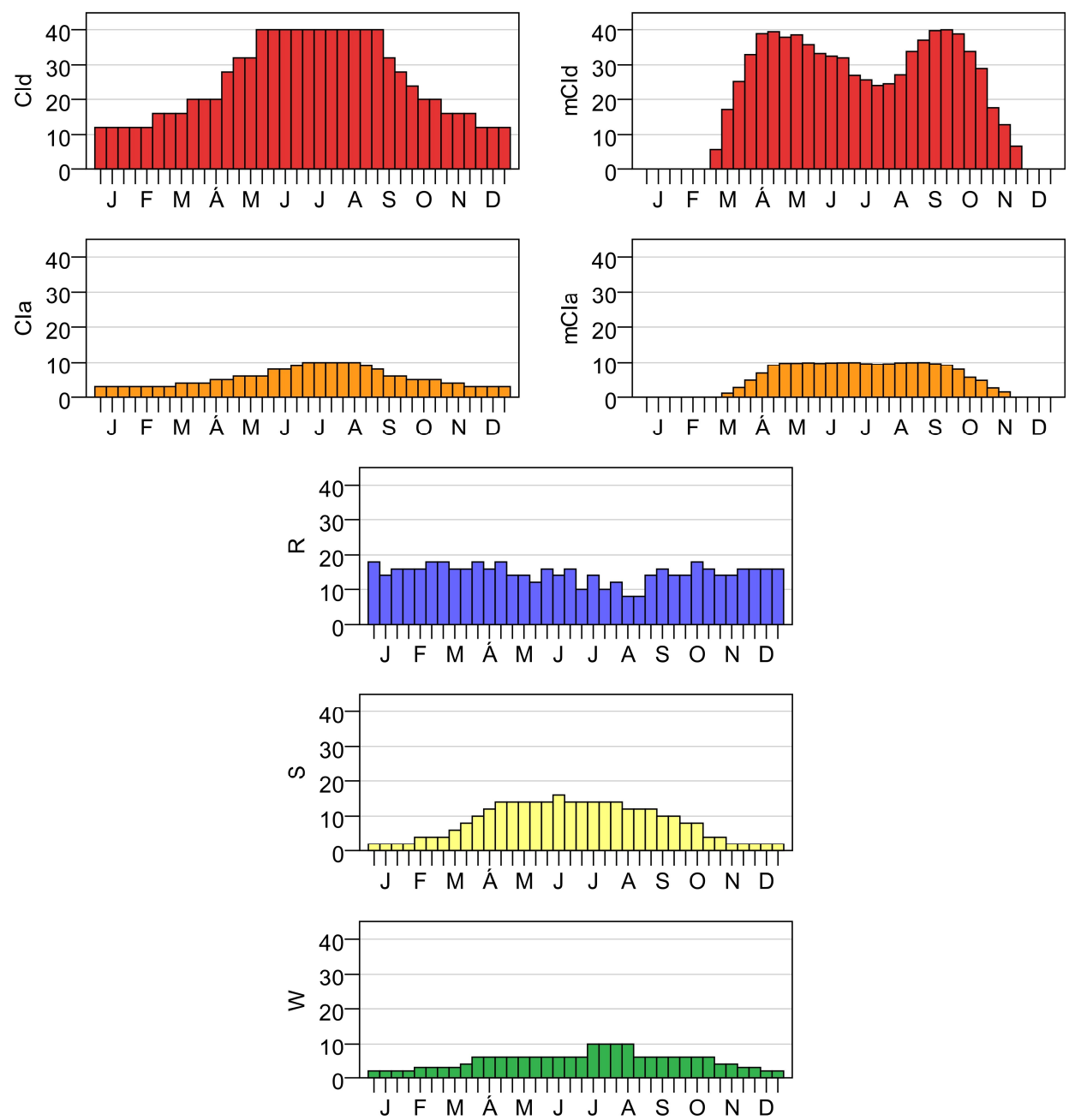

B

Berlin

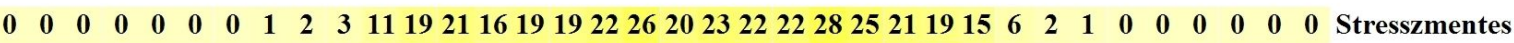

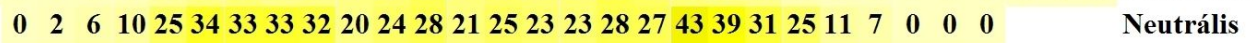

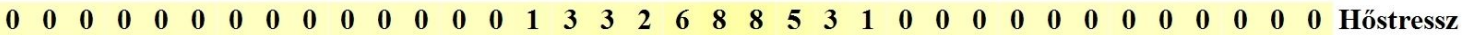

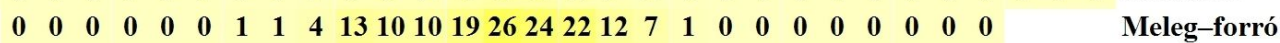

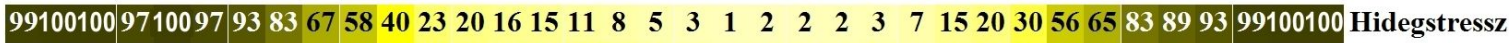
$94856961422521181629252021111211132071420305564838893 \quad$ Húvös-hideg

$\begin{array}{lllllllllllllllllllllllllllllllllllllllllllll}0 & 0 & 0 & 0 & 0 & 0 & 0 & 0 & 0 & 0 & 0 & 0 & 0 & 0 & 6 & 7 & 11 & 11 & 16 & 28 & 28 & 20 & 26 & 17 & 7 & 3 & 0 & 1 & 0 & 0 & 0 & 0 & 0 & 0 & 0 & 0 & \text { Fülledtség }\end{array}$ 1721201921201823373643474431374142373642394437364138432837241818161817 N Napsütés $\begin{array}{lllllllllllllllllllllllllllllllllllllll}16 & 13 & 17 & 9 & 12 & 8 & 6 & 8 & 9 & 4 & 4 & 3 & 5 & 8 & 6 & 7 & 4 & 3 & 8 & 5 & 7 & 5 & 9 & 7 & 7 & 8 & 13 & 11 & 13 & 15 & 20 & 17 & 14 & 17 & 20 & 8 & \text { Köd }\end{array}$ 796372697667726574777784746769747276607070746571668072717970687071776971 Száraz nap

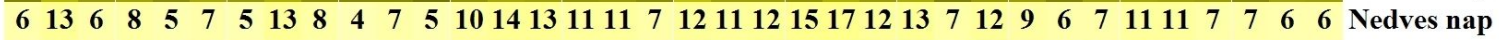
$\begin{array}{llllllllllllllllllllllllllllllllllllll}6 & 5 & 9 & 4 & 1 & 6 & 6 & 7 & 3 & 1 & 1 & 2 & 2 & 1 & 2 & 1 & 2 & 4 & 1 & 1 & 2 & 1 & 1 & 2 & 2 & 2 & 2 & 2 & 1 & 4 & 5 & 3 & 2 & 2 & 3 & 2 & \text { Szeles idő }\end{array}$

$\begin{array}{llllllllllll}\text { I II } & \text { III } & \text { IV } & \text { V } & \text { VI } & \text { VII } & \text { VIII } & \text { IX } & \text { X } & \text { XI } & \text { XII }\end{array}$

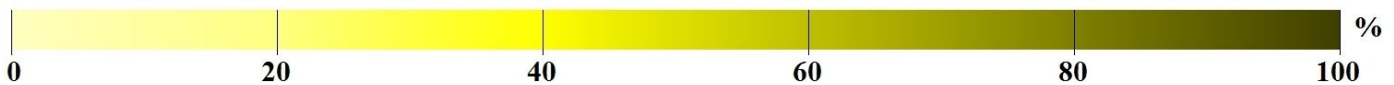

8. ábra: A Turisztikai klíma indexet (TCI) és a módosított Turisztikai klíma indexet (mTCI) felépítő al-indexek évi menete (a), valamint a Klíma-Turizmus-Információs-Rendszer (CTIS) (b) Berlinben, tíznapos felbontásban (2000-2010). Az egyes TCI és mTCI al-indexekkel kapcsolatos tudnivalókat a 6.2. ábra magyarázata tartalmazza. A CTIS-ben a termikus stresszre és a höérzetre vonatkozó küszöbértékek az 5.3. táblázaton, a többi paraméteré a 2.5. táblázaton alapulnak 
A
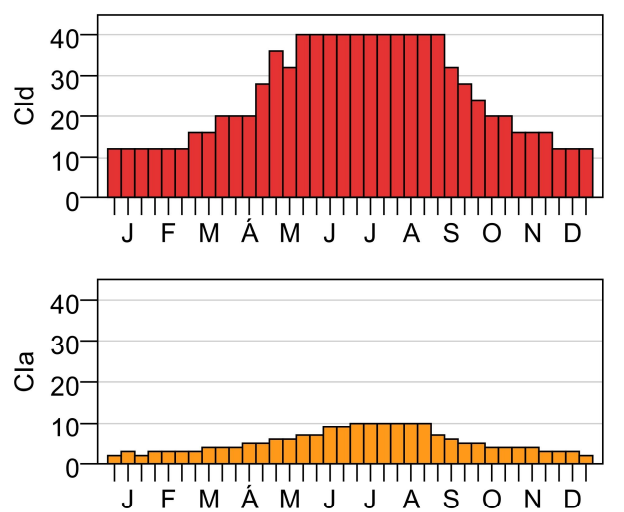

Prága
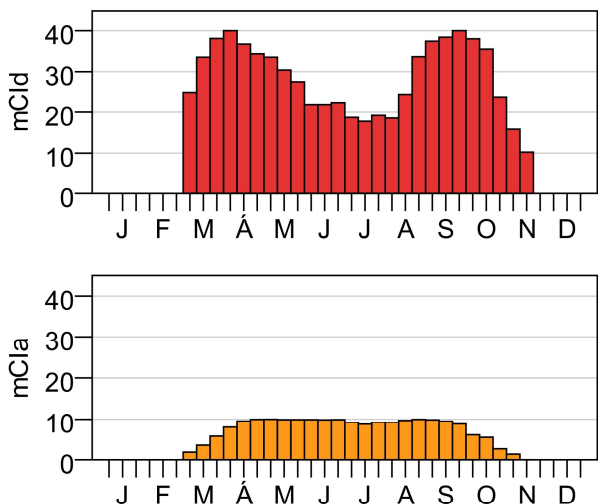
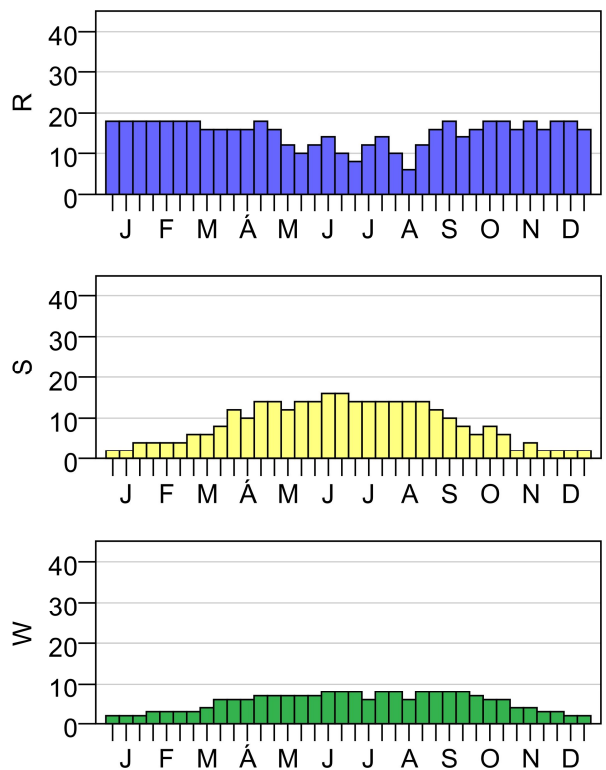

B

Prága

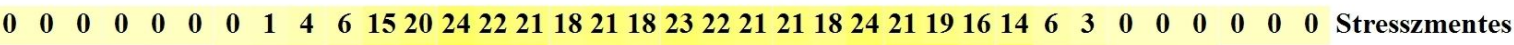

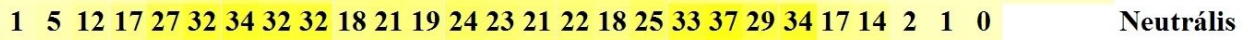

$\begin{array}{lllllllllllllllllllllllllllllllllllllllll}0 & 0 & 0 & 0 & 0 & 0 & 0 & 0 & 0 & 0 & 0 & 0 & 1 & 1 & 3 & 4 & 7 & 5 & 6 & 12 & 13 & 7 & 9 & 4 & 1 & 0 & 0 & 0 & 0 & 0 & 0 & 0 & 0 & 0 & 0 & 0 & \text { Hőstressz }\end{array}$

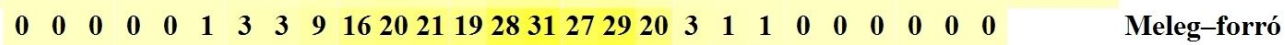

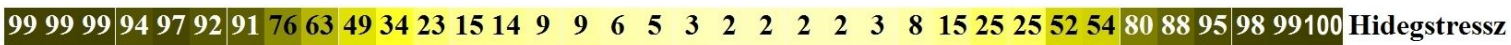
$92786551362417151030201919141112151481525255154808895 \quad$ Húvös-hideg

$\begin{array}{llllllllllllllllllllllllllllllllllllllll}0 & 0 & 0 & 0 & 0 & 0 & 0 & 0 & 0 & 0 & 0 & 0 & 0 & 0 & 5 & 10 & 14 & 18 & 16 & 23 & 22 & 19 & 21 & 19 & 7 & 3 & 0 & 1 & 0 & 0 & 0 & 0 & 0 & 0 & 0 & 0 & \text { Fülledtség }\end{array}$ 172024212128192333404048453536394445384042434444503640233525182014171417 Napsütés

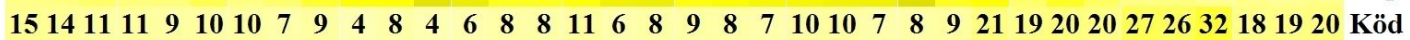
$7480737381747572748177816862676767636771756571787176767182807376 \quad 68807179$ Száraz nap $\begin{array}{llllllllllllllllllllllllllllllllllllllll}6 & 5 & 2 & 1 & 5 & 2 & 4 & 5 & 11 & 6 & 5 & 3 & 10 & 20 & 15 & 10 & 11 & 20 & 18 & 14 & 10 & 15 & 16 & 13 & 6 & 7 & 10 & 5 & 7 & 5 & 9 & 4 & 7 & 9 & 4 & 8 & \text { Nedves nap }\end{array}$ $\begin{array}{lllllllllllllllllllllllllllllllllllllll}0 & 1 & 0 & 0 & 1 & 1 & 1 & 0 & 1 & 1 & 1 & 0 & 0 & 0 & 0 & 0 & 0 & 0 & 0 & 0 & 0 & 0 & 0 & 0 & 0 & 0 & 0 & 0 & 0 & 0 & 0 & 0 & 0 & 0 & 0 & 0 & \text { Szeles } & \text { ido } & 0\end{array}$

$\begin{array}{llllllllllll}\text { I } & \text { II } & \text { III } & \text { IV } & \text { V } & \text { VI } & \text { VII } & \text { VIII } & \text { IX } & \text { X } & \text { XI } & \text { XII }\end{array}$

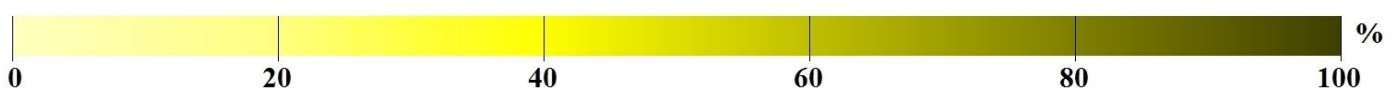

9. ábra: A Turisztikai klíma indexet (TCI) és a módosított Turisztikai klíma indexet (mTCI) felépítő al-indexek évi menete (a), valamint a Klíma-Turizmus-Információs-Rendszer (CTIS) (b) Prágában, tíznapos felbontásban (2000-2010). Az egyes TCI és mTCI al-indexekkel kapcsolatos tudnivalókat a 6.2. ábra magyarázata tartalmazza. A CTIS-ben a termikus stresszre és a hőérzetre vonatkozó küszöbértékek az 5.3. táblázaton, a többi paramé- 
A
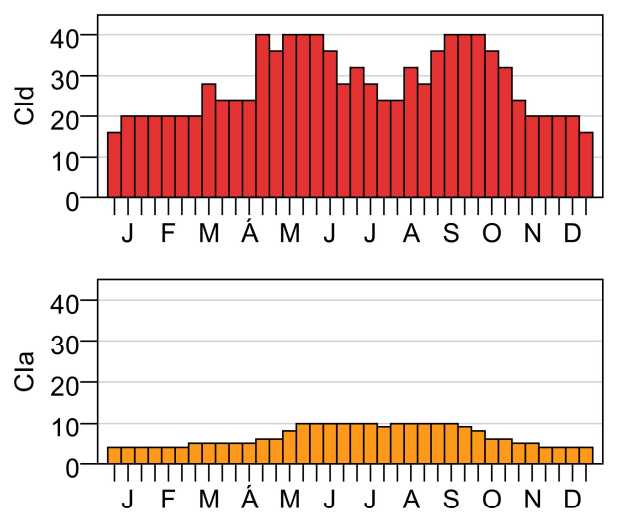

Madrid
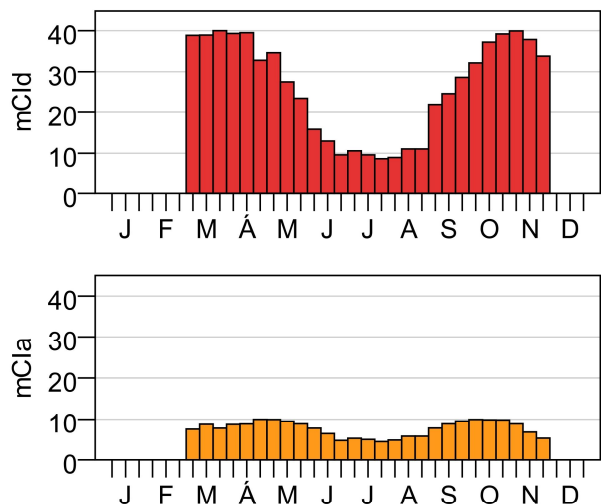
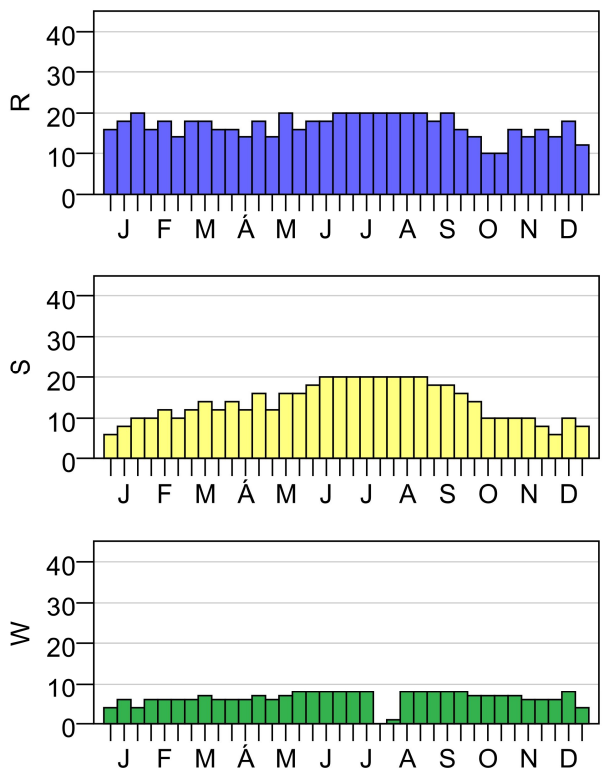

B

Madrid

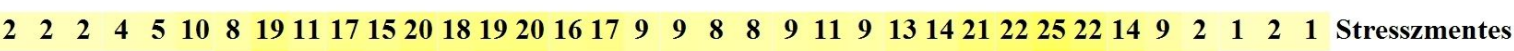
$1831233027302529261617910998 \quad 9 \quad 109016182630403730209$ Neutrális

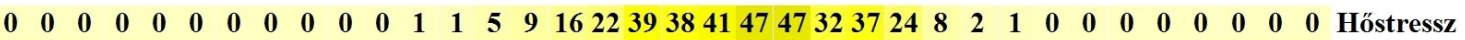

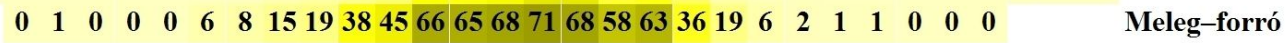

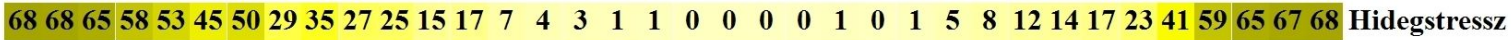
$\begin{array}{llllllllllllllllllllllllll}513137 & 28 & 27 & 16 & 18 & 8 & 5 & 12 & 7 & 3 & 3 & 3 & 3 & 4 & 7 & 4 & 1 & 4 & 8 & 11 & 14 & 17 & 22 & 40 & 59 & \text { Húvös-hideg }\end{array}$

$\begin{array}{lllllllllllllllllllllllllllllllllllllllllll}\mathbf{0} & \mathbf{0} & \mathbf{0} & \mathbf{0} & \mathbf{0} & \mathbf{0} & \mathbf{0} & \mathbf{0} & \mathbf{0} & \mathbf{0} & \mathbf{0} & \mathbf{0} & \mathbf{0} & \mathbf{0} & \mathbf{0} & \mathbf{0} & \mathbf{4} & 2 & 1 & 1 & 1 & 2 & 1 & 2 & 5 & 1 & 1 & 0 & 1 & 0 & 0 & 0 & 0 & 0 & 0 & 0 & \text { Fülledtség }\end{array}$ 364855465245526642494358455852616386868593878483746865595751535653405948 Napsültés $\begin{array}{lllllllllllllllllllllllllllllllllllll}15 & 18 & 5 & 9 & 5 & 9 & 8 & 3 & 2 & 3 & 3 & 3 & 3 & 2 & 3 & 1 & 1 & 0 & 0 & 0 & 0 & 0 & 0 & 0 & 0 & 0 & 2 & 4 & 5 & 3 & 8 & 7 & 7 & 15 & 9 & 10 & \text { Köd }\end{array}$

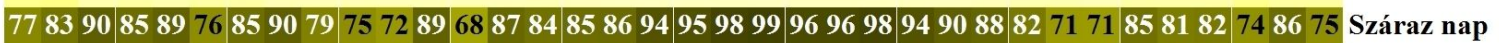
$\begin{array}{lllllllllllllllllllllllllllllllllllllll}11 & 6 & 2 & 8 & 5 & 12 & 6 & 6 & 7 & 9 & 13 & 3 & 11 & 2 & 8 & 7 & 5 & 2 & 2 & 2 & 0 & 1 & 3 & 0 & 5 & 3 & 6 & 7 & 15 & 18 & 6 & 9 & 8 & 13 & 5 & 15 & \text { Nedves nap }\end{array}$

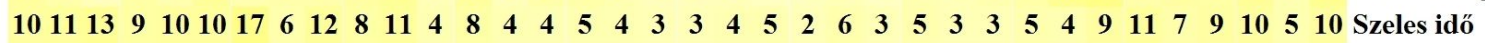

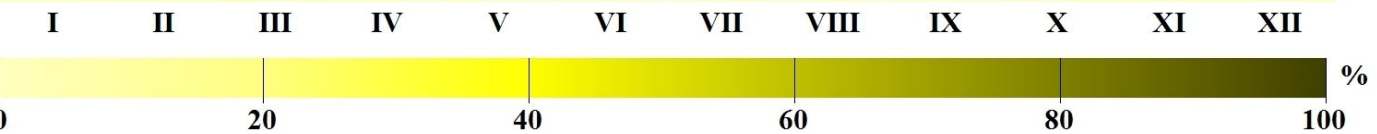

10. ábra: A Turisztikai klíma indexet (TCI) és a módosított Turisztikai klíma indexet (mTCI) felépítő al-indexek évi menete (a), valamint a Klíma-Turizmus-Információs-Rendszer (CTIS) (b) Madridban, tíznapos felbontásban (2000-2010). Az egyes TCI és mTCI al-indexekkel kapcsolatos tudnivalókat a 6.2. ábra magyarázata tartalmazza. A CTIS-ben a termikus stresszre és a höérzetre vonatkozó küszöbértékek az 5.3. táblázaton, a többi paramé- 

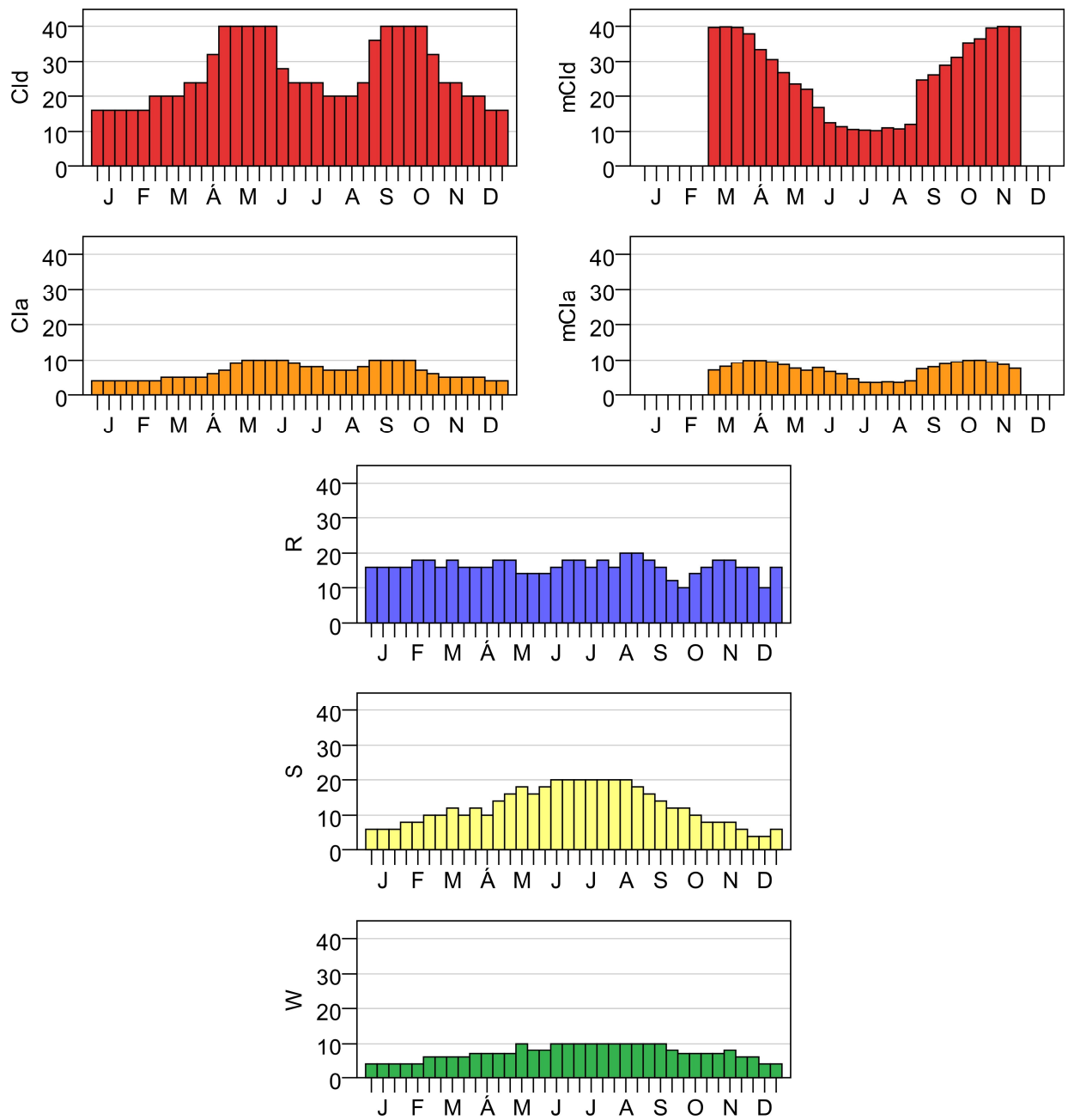

B

\section{Szaloniki}

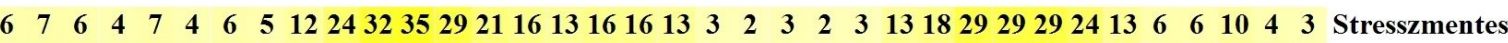
$15203648464226171112171610322332 \quad 2131733344848352720 \quad$ Neutrális

$\begin{array}{llllllllllllllllllllllllllllllllllllll}0 & 0 & 0 & 0 & 0 & 0 & 0 & 0 & 1 & 1 & 3 & 4 & 3 & 6 & 11 & 9 & 23 & 30 & 38 & 52 & 51 & 51 & 53 & 35 & 8 & 4 & 4 & 3 & 1 & 1 & 0 & 0 & 0 & 0 & 0 & 0 & \text { Hóstressz }\end{array}$

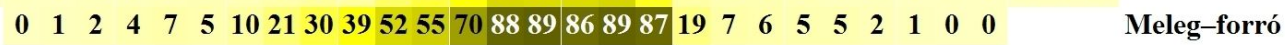

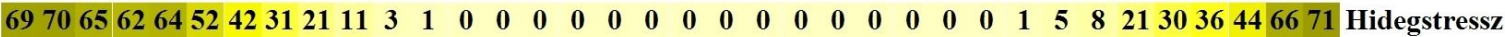

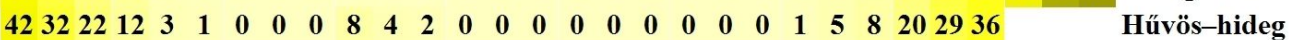

$\begin{array}{llllllllllllllllllllllllllllllllllllllll}0 & 0 & 0 & 0 & 0 & 0 & 0 & 0 & 0 & 0 & 1 & 2 & 3 & 17 & 41 & 34 & 58 & 61 & 77 & 70 & 81 & 85 & 84 & 76 & 48 & 38 & 30 & 29 & 18 & 13 & 7 & 2 & 0 & 0 & 0 & 0 & \text { Fülledtség }\end{array}$ 454041514048435243483555606156637683849183839187716659614845424240293239 Napsütés $\begin{array}{lllllllllllllllllllllllllllllllllllll}18 & 9 & 16 & 12 & 9 & 11 & 5 & 5 & 8 & 5 & 9 & 3 & 1 & 1 & 1 & 1 & 0 & 1 & 0 & 0 & 0 & 0 & 0 & 0 & 1 & 1 & 3 & 3 & 10 & 6 & 9 & 14 & 17 & 20 & 17 & 16 & \text { Köd }\end{array}$

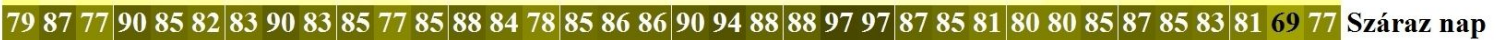
$\begin{array}{llllllllllllllllllllllllllllllllllllllll}8 & 4 & 8 & 5 & 3 & 4 & 7 & 3 & 7 & 9 & 10 & 5 & 5 & 10 & 8 & 9 & 5 & 4 & 5 & 3 & 4 & 5 & 3 & 2 & 5 & 5 & 11 & 7 & 14 & 3 & 7 & 6 & 8 & 11 & 14 & 7 & \text { Nedves nap }\end{array}$ $\begin{array}{llllllllllllllllllllllllllllllllllllll}8 & 8 & 11 & 10 & 10 & 7 & 8 & 7 & 9 & 4 & 2 & 2 & 2 & 4 & 3 & 4 & 3 & 2 & 4 & 4 & 3 & 3 & 3 & 4 & 8 & 3 & 2 & 3 & 6 & 4 & 5 & 7 & 7 & 7 & 12 & 8 & \text { Szeles idő }\end{array}$

$\begin{array}{llllllllllll}\text { I } & \text { II } & \text { III } & \text { IV } & \text { V } & \text { VI } & \text { VII } & \text { VIII } & \text { IX } & \text { X } & \text { XI } & \text { XII }\end{array}$

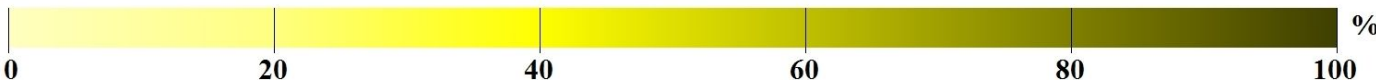

11. ábra: A Turisztikai klíma indexet (TCI) és a módosított Turisztikai klíma indexet (mTCI) felépítő al-indexek évi menete (a), valamint a Klíma-Turizmus-Információs-Rendszer (CTIS) (b) Szalonikiben, tíznapos felbontásban (2000-2010). Az egyes TCI és mTCI al-indexekkel kapcsolatos tudnivalókat a 6.2. ábra magyarázata tartalmazza. A CTIS-ben a termikus stresszre és a höérzetre vonatkozó küszöbértékek az 5.3. táblázaton, a többi paraméteré a 2.5. táblázaton alapulnak 